\title{
Registration in the international prospective register of systematic reviews (PROSPERO) of systematic review protocols was associated with increased review quality
}

\author{
Sideri, Sofia ; Papageorgiou, Spyridon N ; Eliades, Theodore
}

\begin{abstract}
OBJECTIVES: A priori registration of systematic review protocols in international prospective register of systematic reviews (PROSPERO) can help reduce selective reporting of outcomes. The aim of this study was to assess the association between registration of orthodontic systematic reviews in PROSPERO and review quality with the Assessment of Multiple Systematic Reviews (AMSTAR) tool. STUDY DESIGN AND SETTING: Seven databases were searched for systematic reviews with/without meta-analysis in orthodontics published between 2012 and 2016. After duplicate study selection and data extraction, the quality of identified reviews was assessed in duplicate with the AMSTAR tool. Descriptive statistics of medians and interquartile ranges (IQRs) and chi-square/Fisher exact tests were calculated. Univariable/multivariable linear regression modeling was implemented to assess the effect of review registration on \%AMSTAR score at of 5\%. RESULTS: A total of 182 orthodontic systematic reviews were identified, $37(20.3 \%)$ of which were registered. Considerable differences were seen in AMSTAR between registered $($ median $=86.4 \%$ IQR $=77.3-95.5 \%$ ) and nonregistered reviews $($ median $=72.7 \%$ IQR $=$ 59.1-81.8\%). After adjustment, registration in PROSPERO was associated with an average increase in \%AMSTAR score of $6.6 \%$ (95\% confidence interval $=1.0-12.3 \%)$. CONCLUSION: Although only a small percentage of orthodontic systematic reviews was registered a priori in PROSPERO, registered reviews were of higher quality than nonregistered reviews.
\end{abstract}

DOI: https://doi.org/10.1016/j.jclinepi.2018.01.003

Posted at the Zurich Open Repository and Archive, University of Zurich

ZORA URL: https://doi.org/10.5167/uzh-169522

Journal Article

Accepted Version

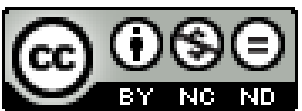

The following work is licensed under a Creative Commons: Attribution-NonCommercial-NoDerivatives 4.0 International (CC BY-NC-ND 4.0) License.

Originally published at:

Sideri, Sofia; Papageorgiou, Spyridon N; Eliades, Theodore (2018). Registration in the international prospective register of systematic reviews (PROSPERO) of systematic review protocols was associated with increased review quality. Journal of Clinical Epidemiology, 100:103-110.

DOI: https://doi.org/10.1016/j.jclinepi.2018.01.003 


\section{Registration in the international prospective register of systematic reviews (PROSPERO) of systematic review protocols was associated with increased review quality}

Sofia Sideri ${ }^{\mathrm{a}}$, Spyridon N. Papageorgiou ${ }^{\mathrm{a}, *}$, Theodore Eliades ${ }^{\mathrm{a}}$

${ }^{a}$ Clinic of Orthodontics and Pediatric Dentistry, Center of Dental Medicine, University of Zurich, Plattenstrasse 11, 8032 Zurich, Switzerland

Short title: Impact of systematic review registration on quality

*Corresponding author

Spyridon N. Papageorgiou, Clinic of Orthodontics and Pediatric Dentistry, Center of Dental Medicine, University of Zurich, Plattenstrasse 11, 8032 Zurich, Switzerland; Tel: +41 44634 32 87; Fax: +41 44634 43 35; snpapage@gmail.com (can be published).

Conflicts of interest: none.

Words in abstract: 200/200

Words in text: $2873 / 5000$

References: 30

Figures: 2

Tables: 4 


\section{Abstract}

Objectives: A priori registration of systematic review protocols in International prospective register of systematic reviews (PROSPERO) can help reduce selective reporting of outcomes. Aim of this study was to assess the association between registration of orthodontic systematic reviews in PROSPERO and review quality with the Assessment of Multiple Systematic Reviews (AMSTAR) tool.

Study Design and Setting: Seven databases were searched for systematic reviews with/without metaanalysis in orthodontics published between 2012-2016. After duplicate study selection and data extraction, the quality of identified reviews was assessed in duplicate with the AMSTAR tool. Descriptive statistics of medians and Interquartile Ranges (IQR) and chi-square/Fisher exact tests were calculated. Uni/multivariable linear regression modelling was implemented to assess the effect of review registration on $\%$ AMSTAR score at $\alpha$ of $5 \%$.

Results: A total of 182 orthodontic systematic reviews were identified, 37 (20.3\%) of which were registered. Considerable differences were seen in AMSTAR between registered (median=86.4\%; IQR=77.3-95.5\%) and non-registered reviews (median=72.7\%; IQR=59.1-81.8\%). After adjustment, registration in PROSPERO was associated with an average increase in \% AMSTAR score of $6.6 \%$ (95\% confidence interval $=1.0-12.3 \%)$.

Conclusions: Although only a small percentage of orthodontic systematic reviews was registered a priori in PROSPERO, registered reviews were of higher quality than non-registered reviews.

Keywords: systematic review; meta-analysis; orthodontics; quality; evidence based dentistry 


\section{Manuscript}

\section{Introduction}

Systematic reviews provide a platform for the critical appraisal and synthesis of the totality of clinical evidence pertaining to a specific research question, thereby enabling the formulation of informed clinical recommendations [1] and the guidance of future research. The main strengths of systematic reviews are founded in the use of pre-defined, transparent, and reproducible methods pertaining to selection, extraction, appraisal, and synthesis. However, several types of bias have been documented in various phases of the scientific research procedure [2] and systematic reviews are likewise susceptible to many of them.

Outcome reporting bias is a form of bias occurring, when the choice of outcome reporting is influenced by the outcomes' results, with the scale usually leaning towards studies with statistically significant or 'attractive' results [3]. Outcome reporting bias might exist in clinical trials with multiple measured outcomes, especially if these have not been transparently pre-specified in the trial's protocol $[4,5]$. Likewise, a comparison between a priori protocols of systematic reviews and the subsequent published reports found considerable discrepancies between them, which increased the likelihood of reporting statistically significant outcomes [6-9]. Therefore, this was interpreted as signs of outcome reporting bias in systematic reviews.

A priori registration of systematic review protocols enables the reader to check for any outcome reporting bias by comparing the outcomes between the protocol and final published article [6-9]. Furthermore, a large number of systematic reviews seem to have overlap in terms of eligible interventions, settings, and types of studies [10] — something that is deemed as unnecessary duplication or research waste and can be theoretically prevented by the a priori registration of the systematic reviews' protocol in an openly accessible receptacle [11-13].

The idea of protocol registration was first disseminated in the Preferred Reporting Items for Systematic Review and Meta-Analysis (PRISMA) statement in 2009 [14]. Following this publication, the United Kingdom Centre for Reviews and Dissemination developed and launched the international prospective register of systematic reviews (PROSPERO) in 2011. The aim of this registry and statement 
was to minimize reporting bias through transparency in the review process and to potentially reduce unplanned duplication of reviews [11]. Although the uptake of PROSPERO by systematic review authors has been increasing the last years and more than 24000 review protocols have been registered up to July 2017, the effect of PROSPERO registration on the quality of subsequent review publications has been only slightly assessed.

The recent study of Tsujimoto et al. [15] assessed the PROSPERO registration rate of systematic reviews published in high-impact medical journals and indicated that only $21 \%$ of them had their protocols registered, but could not find any evidence of outcome reporting bias or any association with PROSPERO registration and citation of the reporting guidelines for systematic reviews. However, no data specific to the field of orthodontics was provided, while the inclusion of only high-impact journals might provide an overly optimistic image of protocol registration, due to considerable differences of systematic review quality according to journal characteristics [16,17]. Finallly, the study of Tsujimoto et al [15] confined its analyses to the identification of predictors for review registration, but did not actually appraise the quality of the published systematic reviews. To evaluate the quality of systematic reviews, several tools have been suggested, with one of the most widely-accepted ones being the Assessment of Multiple Systematic Reviews (AMSTAR) tool, which incorporates an 11-item checklist [18]. Therefore, aim of the current study was to investigate to which extent registration a priori in PROSPERO of systematic reviews in orthodontics has an effect on the review quality and the null hypothesis was that there is no difference in the average AMSTAR score between registered and non-registered systematic reviews in orthodontics.

\section{Materials and methods}

Electronic search strategies were developed and executed on January 2017 to identify systematic reviews relevant to orthodontics without restrictions for publication language or publication status in MEDLINE (via PubMed), Cochrane Database of Systematic Reviews, Cochrane Database of Abstracts

of Reviews of Effects, Embase, Scopus, Web of Science, and Virtual Health Library (including Bibliografia Brasileira de Odontologia and LILACS) (Appendix 1). As the PROSPERO register was 
launched in February 2011, we allowed one year for dissemination of the register and included systematic reviews from 2012 and on. Eligible for this study were orthodontic systematic reviews with or without metaanalysis that were either registered in PROSPERO according to their publication text or were non-registered and had been published at any kind of scientific journal. We defined as systematic review any publication that termed itself as such and used a systematic approach to identify, select, and appraise studies in order to answer a research question. As Cochrane Reviews are consistently registered during the protocol stage, they were excluded from the present study. Additionally, narrative reviews, clinical, or in vitro studies were excluded. Identified reports were screened sequentially by title, abstract, and full text to check for eligibility. Extra material included as online appendix in the original articles was acquired, when needed.

Data to be collected were defined a priori from pilot searching of the literature and discussion among the authors, based on previous reports $[16,17]$. Epidemiological characteristics were based on the corresponding author of each article including country, continent, and clinical setting (i.e. university or another setting). Additionally, data were extracted on publication year, number of authors, involvement of a statistician/epidemiologist, inclusion of multiple centers, funding, publication journal, and on whether the systematic review was registered in PROSPERO. The results pertaining to the registration rate of orthodontic systematic reviews and possible predictors for registration have been previously reported [19].

Quality assessment of included systematic reviews was conducted using the 11-item AMSTAR tool [18]. Each of the 11 items (Appendix 2) was assessed using a four-point scale: "Yes", "Partly", "No", and "Not applicable". "Partly" was used in case of partly fulfillment of an item. For example, the fifth item, " $A$ list of included and excluded studies should be provided", was scored as "Partly" if either the included or the excluded studies were listed in the publication. Items that might be possibly "not applicable" were excluded from the maximum scoring capability of each systematic review. Summary scores were extracted by giving one point for each "Yes" and half a point for each "Partly" (instead of just giving only one point for each "Yes") in an attempt to maximize data output and are reported as percentages from the maximum points each review could get. 
Finally, we investigated if PROSPERO registration was associated with specific review characteristics pertaining to the completeness of the systematic review procedures, like involvement of a statistician or epidemiologist, reporting of the PRISMA statement in the review text, use of the Grading of Recommendations Assessment, Development and Evaluation (GRADE) approach, inclusion of a flowdiagram showing identification of studies for the review, inclusion of only randomized trials, and inclusion of quantitative data synthesis (meta-analysis).

All study procedures were conducted by two authors (SS, SNP) with any disagreements resolved by a third author (TE). The two scoring authors (SS, SNP) were calibrated prior to the actual procedures in three sets of 50 papers at a time, until over $90 \%$ agreement was seen. Finally, a random set of 50 papers was checked afterwards for consistency from both authors.

For the statistical analysis, initially descriptive statistics were calculated as absolute and relative frequencies for categorical outcomes and medians and Interquartile Ranges (IQR) for continuous outcomes, after appropriate normality testing. Crude differences in the fulfillment of each AMSTAR item or in review methodological traits between registered / non-registered reviews were investigated with chi-square/ Fisher exact tests, as appropriate. Radar plots were constructed to depict the \% proportion of included systematic reviews that fulfilled fully or partly each of the 11 AMSTAR items. Crude differences in the average \%AMSTAR score between registered / non-registered reviews were investigated with Mann-Whitney tests. Furthermore, generalized linear models were used to evaluate the association between registration in PROSPERO and \%AMSTAR score. Assumptions of linear regression were checked including graphical and statistical tests for homoscedasticity of residuals, multicollinearity of predictors, and model misspecification (Appendix 3). Results were expressed as unstandardized regression coefficients and the corresponding 95\% Confidence Intervals (CI). First, bivariable models were constructed for each characteristic. Afterwards, all characteristics with $\mathrm{P}<0.2[20]$ in the bivariable model, we entered in a multivariable model to calculate net change in \%AMSTAR attributed to registration in PROSPERO after adjusting for confounding. Additionally, differences in the proportion of reviews fulfilling partly or completely each separate AMSTAR criterion were assessed with univariable/multivariable logistic 
regression and reported as Odd Ratios (OR). All analyses were performed in Stata version 14 (StataCorp LP, College Station, TX) with a two-tailed $\mathrm{P}<0.05$ considered as significant.

\section{Results}

The electronic search yielded initially a total of 2141 citations, from which 1176 citations remained for screening after de-duplication (Fig. 1; Appendix 4). After applying the eligibility criteria, a total of 182 systematic reviews were finally included, which were published between 2012 and 2016 (Table 1).

The included systematic reviews originated from at least four different continents (Table 1) and 34 different countries, with the most prolific countries being Brazil $(n=27 ; 14.8 \%)$, China $(n=24 ; 13.2 \%)$, Italy $(\mathrm{n}=18 ; 9.9 \%)$, and United Kingdom $(\mathrm{n}=12 ; 6.6 \%)$. The most prolific continent was Europe $(\mathrm{n}=79 ; 43.4 \%)$ and Asia $(n=50 ; 27.5 \%)$. From these 182 systematic reviews, the majority had a university affiliation $(n=170 ; 93.4 \%)$, included four to six authors $(n=103 ; 56.6 \%)$, and included more than one research centers $(\mathrm{n}=101 ; 55.5 \%)$. On the other hand, only few systematic reviews included a statistician/epidemiologist $(\mathrm{n}=26 ; 14.3 \%)$ or received funding $(\mathrm{n}=41 ; 22.5 \%)$. The included systematic reviews were mostly published in orthodontic specialty journals $(n=94 ; 51.7 \%)$, followed by general dentistry journals $(n=58 ; 31.9 \%)$, and non-dental journals $(n=30 ; 16.5 \%)$. Finally, the identified systematic reviews included between 0 and 377 primary studies (median of 12 studies per review; interquartile range of 7 to 24 studies per review). Out of the 182 identified systematic reviews, only 37 systematic reviews (20.3\%) were registered in PROSPERO (Table 1).

Assessment of systematic review quality with the AMSTAR tool indicated that considerable variation was seen in the fulfillment of the 11 items of the tool between registered and non-registered reviews (Table 2; Fig. 2). Significant improvements for registered reviews compared to non-registered ones in terms of partial or complete fulfillment were seen for item 1 (“Was an 'a priori' design provided?"; 97.3\% to $28.1 \%$, respectively), item 4 ("Was the status of publication used as an inclusion criterion?"; $75.8 \%$ to $61.4 \%$, respectively), item 7 (“Was the scientific quality of the included studies assessed and documented?"; $100 \%$ to $84.8 \%$, respectively), item 8 ("Was the scientific quality of the included studies used appropriately 
in formulating conclusions?"; $100 \%$ to $82.1 \%$, respectively), and item 10 (“Was the likelihood of publication bias assessed"; $64.9 \%$ to $41.4 \%$, respectively).

The measured cumulative absolute AMSTAR score across all included reviews (median=6.5; $\mathrm{IQR}=6.5-9.5)$ was expressed as \% percentage of the maximum score $($ median=77.3\%; IQR=59.1-86.4\%) for the present study. The cumulative \%AMSTAR score for each systematic review varied considerably between registered $(\mathrm{n}=37$; median=86.4\%; IQR=77.3-95.5\%) and non-registered reviews $(\mathrm{n}=145$; median=72.7\%; IQR=59.1-81.8\%; $\mathrm{P}<0.001$ ). The results of the bivariable and multivariable regression analyses for the effect of registration in PROSPERO on the quality of systematic review can be seen in Table 3. Apart from the factor of PROSPERO registration that was forcibly entered into both models, the bivariable analyses indicated publication year, statistician involvement, multicentered review collaboration, citation of PRISMA guidelines, reporting of a flowdiagram, use of the GRADE approach, meta-analysis, and journal type as possible confounders (Appendix 5), which were entered in the multivariable model. Based on this adjusted model, PROSPERO registration was associated with a net increase in \%AMSTAR score by $6.6 \%$ (95\% $\mathrm{CI}=1.0$ to $12.3 \%$; $\mathrm{P}=0.02)$. Furthermore, increased \%AMSTAR scores were associated with involvement of a statistician in the review team (net increase of 6.6\%), journal category (increase of $5.3 \%$ for reviews published in dental specialty compared to general dental journals), PRISMA citation (net increase of 6.2\%), use of the GRADE approach (net increase of 11.8\%), inclusion of a flowdiagram (net increase of $11.7 \%$ ), and inclusion of meta-analyses (net increase of 9.2\%). On the other side, the number of included studies seemed to have an inversely proportional relationship with \%AMSTAR score (with a net decrease of $7.5 \%$ for reviews including $>30$ studies compared to ones including < 10 studies).

Additionally, we investigated if PROSPERO registration was associated with specific characteristics pertaining to the completeness of the systematic review procedures (Table 4). Compared to non-registered reviews, registered reviews were more likely to cite the PRISMA guidelines (78.4\% versus $51.0 \%)$, to use the GRADE approach (40.5\% versus $17.9 \%)$, to include a flowdiagram (100.0\% versus $89.0 \%)$, and to perform meta-analysis $(75.78 \%$ versus $55.9 \%)$. 
Finally, on the basis of each AMSTAR item separately, PROSPERO registration was associated with increased odds of fulfilling at least partly item 1 (“Was an 'a priori' design provided?") and item 10 (“Was the likelihood of publication bias assessed?") (Appendix 6). After controlling for confounders (Appendix 7), only item an improvement in 1 remained associated with PROSPERO registration (Appendix 8). It must be here noted that item 3 ("Was a comprehensive literature search performed?"), item 5 (“Was a list of included and excluded studies provided?"), item 6 (“Were the characteristics of the included studies provided?"), item 7 (“Was the scientific quality of the included studies assessed and documented?"), and item 8 (“Was the scientific quality of the included studies used appropriately in formulating conclusions?") could not be tested statistically, since item fulfillment was perfectly associated with registration.

\section{Discussion}

The present study assesses the association between a priori registration of orthodontic systematic review protocols in PROSPERO and the quality of the systematic reviews published between 2012-2016 according to the AMSTAR tool. The results suggest that registration in PROSPERO was associated with improvements in 5 out of the 11 AMSTAR items (Table 2) and a net increase in review quality of about 6.6\% (95\% CI=1.0-12.3\%; Table 3). Additionally, registered reviews were more likely to cite PRISMA, use GRADE, include a flowdiagram, and to include meta-analytical synthesis compared to non-registered ones (Table 4).

To our knowledge, this is the first study to investigate the effect of a priori registration of systematic review protocols on the review quality of the subsequent published reports in any biomedical field. Tsujimoto et al. [15] assessed the registration rate of 284 systematic reviews published in high-impact medical journals, but focused on the rate of statistically significant results as a proxy for outcome reporting bias and not on overall review quality. The finding that registration in PROSPERO was associated with higher review quality might be possibly explained by the fact that a detailed protocol form that delineates all review procedures from formulation of a research question to synthesis and dissemination of the results has to be completed and submitted to PROSPERO by the review authors. This requires that the review 
authors have actually invested time to plan all review procedures beforehand and therefore might indirectly result in more robust methods. Alternatively, authors with detailed a priori protocols might find it easier to fill out and submit their review protocols in PROSPERO. It must be noted here that PROSPERO protocols are not checked for completeness and can be submitted with very limited information and as such. For example, review registration was not associated with any improvement on item 3 ("Was a comprehensive literature search performed?"), even though comprehensiveness of the literature search is a very important aspect of systematic reviews. A priori registration of systematic review protocols might enhance transparency and minimize outcome reporting bias [5], although a previous study [15] failed to find such evidence. Furthermore, a priori registration might help avoid waste of research resources $[21,22]$ due to redundant research duplication that might be caused by multiple systematic reviews being produced on the same or overlapping subjects.

Several factors, were associated with \%AMSTAR score. Inclusion of a statistician or an epidemiologist in the review team was also associated with an increase in \%AMSTAR score (Table 3). This has been previously reported for both medical $[23,24]$ and orthodontic systematic reviews $[16,17]$ and has been associated with higher submission acceptance rates [25]. This could be attributed to modest statistical skills of the average clinical medical or orthodontic researchers and students [26,27].

Systematic reviews published in orthodontic specialty journals had on average higher \%AMSTAR scores than systematic reviews published in general dentistry journals (Table 3). This improvement in the quality of orthodontic systematic reviews through the later years has been documented $[16,17]$ and might be attributed to consistent interest and efforts from orthodontic research groups to promote evidence based oral health, as well as editorial initiatives in this direction $[28,29]$.

Additionally, the \%AMSTAR score was associated with the number of included primary studies in the systematic review. Reviews with more than 30 included studies had considerably lower \%AMSTAR score than reviews with less than 10 included studies (Table 3), which is consistent with previous studies $[16,24]$. This could be explained by stricter methodology and eligibility criteria used by the authors, which focus only on less biased designs of orthodontic studies [30] and thereby limit the number of eligible studies. 
Furthermore, registered systematic reviews were more likely to cite the PRISMA guidelines, to use the GRADE approach to grade the quality of evidence, to include a flowdiagram, and to perform metaanalysis than non-registered reviews. These are methodological traits of systematic reviews that are not included in the AMSTAR tool, but are still associated with conduct and reporting completeness for systematic reviews.

However, certain limitations to the approach used in the present study must also be acknowledged. First and foremost, the present study assessed the methodological quality of systematic reviews in orthodontics with the AMSTAR tool [18] and not the risk of bias of the systematic review with the Risk of Bias in Systematic Reviews (ROBIS) tool [31]. This decision was made as the AMSTAR tool exists for a longer time, has found widespread use, has been shown to be reliable, and has undergone internal/external validation [32,33], unlike the ROBIS tool. Secondarily, some systematic reviews might have been missed by our literature search, even though multiple databases were used. Thirdly, we excluded from the present investigation Cochrane reviews in orthodontics, since protocol registration is a prerequisite in Cochrane and does not come in question. However, this could have influenced the results of the study, since orthodontic Cochrane reviews have been shown to be of better quality than non-Cochrane reviews [16,17]. Additionally, we extracted the registration status of each systematic review on pertinent statements from within the systematic review published papers and did not search PROSPERO ourselves. Therefore, if a registered systematic review didn't report its registration in the published paper, this was categorized as non-registered. Furthermore, observed associations in this study cannot establish a cause and effect relationship, due to the study's cross-sectional nature. Unfortunately, after the present study had been completed a revised AMSTAR 2 tool was introduced [34] and therefore it would be interesting to see if present results will be confirmed using AMSTAR 2. Finally, the results of the present study are directly applicable to nonCochrane orthodontic systematic reviews with or without meta-analysis. They could theoretically be transferable to systematic reviews in medicine, since orthodontic reviews had similar if not higher \%AMSTAR scores compared to medical reviews [24]. 


\section{Conclusions}

A priori registration in PROSPERO of systematic review protocols in orthodontics was found to be associated with higher review quality measured with the AMSTAR tool. This bears implications for orthodontics and other biomedical fields with relatively deficient a priori registration of systematic review protocols in PROSPERO. Editorial initiatives could be implemented to encourage the registration of systematic review protocols prior to the actual review procedures in order to enhance methodological quality. 
Acknowledgements

None 


\section{References}

1. Patsopoulos NA, Analatos AA, Ioannidis JP. Relative citation impact of various study designs in the health sciences. JAMA 2005;293:2362-6.

2. Chavalarias D, Ioannidis JP. Science mapping analysis characterizes 235 biases in biomedical research. J Clin Epidemiol 2010;63:1205-15.

3. Dwan K, Altman DG, Arnaiz JA, Bloom J, Chan AW, Cronin E, et al. Systematic review of the empirical evidence of study publication bias and outcome reporting bias. PLoS One 2008;3:e3081.

4. Chan AW, Hrobjartsson A, Haahr MT, Gotzsche PC, Altman DG. Empirical evidence for selective reporting of outcomes in randomized trials: comparison of protocols to published articles. JAMA 2004;291:2457-65.

5. Mathieu S, Boutron I, Moher D, Altman DG, Ravaud P. Comparison of registered and published primary outcomes in randomized controlled trials. JAMA 2009;302:977-84.

6. Kirkham JJ, Altman DG, Williamson PR. Bias due to changes in specified outcomes during the systematic review process. PLoS One 2010;5:e9810.

7. Page MJ, McKenzie JE, Kirkham J, Dwan K, Kramer S, Green S, Forbes A. Bias due to selective inclusion and reporting of outcomes and analyses in systematic reviews of randomised trials of healthcare interventions. Cochrane Database Syst Rev 2014;10:MR000035.

8. Pandis N, Fleming PS, Worthington H, Dwan K, Salanti G. Discrepancies in Outcome Reporting Exist Between Protocols and Published Oral Health Cochrane Systematic Reviews. PLoS One 2015;10:e0137667.

9. Tricco AC, Cogo E, Page MJ, Polisena J, Booth A, Dwan K, MacDonald H, Clifford TJ, Stewart LA, Straus SE, Moher D. A third of systematic reviews changed or did not specify the primary outcome: a PROSPERO register study. J Clin Epidemiol 2016;79:46-54.

10. Siontis KC, Hernandez-Boussard T, Ioannidis JP. Overlapping metaanalyses on the same topic: survey of published studies. BMJ 2013;347:f4501. 
11. Booth A, Clarke M, Dooley G, Ghersi D, Moher D, Petticrew M, Stewart L. The nuts and bolts of PROSPERO: an international prospective register of systematic reviews. Syst Rev 2012;1:2.

12. Moher D. The problem of duplicate systematic reviews. BMJ 2013;347:f5040.

13. Moher D, Booth A, Stewart L. How to reduce unnecessary duplication: use PROSPERO. BJOG 2014;121:784-6.

14. Liberati A, Altman DG, Tetzlaff J, Mulrow C, Gøtzsche PC, Ioannidis JP, et al. The PRISMA statement for reporting systematic reviews and meta-analyses of studies that evaluate health care interventions: explanation and elaboration. J Clin Epidemiol 2009;62:e1-34.

15. Tsujimoto Y, Tsujimoto H, Kataoka Y, Kimachi M, Shimizu S, Ikenoue T, et al. Majority of systematic reviews published in high-impact journals neglected to register the protocols: a metaepidemiological study. J Clin Epidemiol 2017;84:54-60.

16. Papageorgiou SN, Papadopoulos MA, Athanasiou AE. Evaluation of methodology and quality characteristics of systematic reviews in orthodontics. Orthod Craniofac Res 2011;14:116-137.

17. Papageorgiou SN, Papadopoulos MA, Athanasiou AE. Reporting characteristics of meta-analyses in orthodontics: methodological assessment and statistical recommendations. Eur J Orthod 2014;36:7485.

18. Shea BJ, Grimshaw JM, Wells GA, Boers M, Andersson N, Hamel C, et al. Development of AMSTAR: a measurement tool to assess the methodological quality of systematic reviews. BMC Med Res Methodol 2007;7:10.

19. Sideri S, Papageorgiou SN, Eliades T. Are orthodontic systematic reviews registered a priori in PROSPERO? J Orthod 2017 [in press].

20. Maldonado G, Greenland S. Simulation study of confounder-selection strategies. Am J Epidemiol 1993;138:923-36.

21. Ioannidis JP, Greenland S, Hlatky MA, Khoury MJ, Macleod MR, Moher D, et al. Increasing value and reducing waste in research design, conduct, and analysis. Lancet 2014;383:166-75. 
22. Ioannidis JP. The mass production of redundant, misleading, and conflicted systematic reviews and meta-analyses. Milbank Q 2016;94:485-514.

23. Delgado-Rodriguez M, Ruiz-Canela M, De Irala-Estevez J, Llorca J, Martinez-Gonzalez A. Participation of epidemiologists and/or biostatisticians and methodological quality of published controlled clinical trials. J Epidemiol Community Health 2001;55:569-72.

24. Fleming PS, Koletsi D, Seehra J, Pandis N. Systematic reviews published in higher impact clinical journals were of higher quality. J Clin Epidemiol 2014;67:754-9.

25. Altman DG, Goodman SN, Schroter S. How statistical expertise is used in medical research. JAMA 2002;287:2817-20.

26. Perneger TV, Ricou B, Boulvain M, Bovier PA, Herrmann FR, Perrier A, et al. Medical researchers evaluate their methodological skills. J Clin Epidemiol 2004;57:1323-9.

27. Polychronopoulou A, Eliades T, Taoufik K, Papadopoulos MA, Athanasiou AE. Knowledge of European orthodontic postgraduate students on biostatistics. Eur J Orthod 2011;33:434-40.

28. Pandis N, Shamseer L, Kokich VG, Fleming PS, Moher D. Active implementation strategy of CONSORT adherence by a dental specialty journal improved randomized clinical trial reporting. J Clin Epidemiol 2014;67:1044-8.

29. Sarkis-Onofre R, Cenci MS, Demarco FF, Lynch CD, Fleming PS, Pereira-Cenci T, et al. Use of guidelines to improve the quality and transparency of reporting oral health research. J Dent 2015;43:397-404.

30. Papageorgiou SN, Xavier GM, Cobourne MT. Basic study design influences the results of orthodontic clinical investigations. J Clin Epidemiol 2015;68:1512-22.

31. Whiting P, Savović J, Higgins JP, Caldwell DM, Reeves BC, Shea B, et al. ROBIS: A new tool to assess risk of bias in systematic reviews was developed. J Clin Epidemiol 2016;69:225-34.

32. Shea BJ, Bouter LM, Peterson J, Boers M, Andersson N, Ortiz Z, et al. External validation of a measurement tool to assess systematic reviews (AMSTAR). PLoS One 2007;2:e1350. 
33. Shea BJ, Hamel C, Wells GA, Bouter LM, Kristjansson E, Grimshaw J, et al. AMSTAR is a reliable and valid measurement tool to assess the methodological quality of systematic reviews. J Clin Epidemiol 2009;62:1013-20.

34. Shea BJ, Reeves BC, Wells G, Thuku M, Hamel C, Moran J, Moher D, Tugwell P, Welch V, Kristjansson E, Henry DA. AMSTAR 2: a critical appraisal tool for systematic reviews that include randomised or non-randomised studies of healthcare interventions, or both. BMJ 2017;358:j4008. 
TABLES

Table 1. Demographics of included sample of systematic reviews

\begin{tabular}{|c|c|c|c|}
\hline Factor & Category & $\mathbf{n}$ & $\%$ \\
\hline & Total & 182 & $100.0 \%$ \\
\hline \multirow[t]{5}{*}{ Publication year } & 2012 & 23 & $12.6 \%$ \\
\hline & 2013 & 24 & $13.2 \%$ \\
\hline & 2014 & 43 & $23.6 \%$ \\
\hline & 2015 & 38 & $20.9 \%$ \\
\hline & 2016 & 54 & $29.7 \%$ \\
\hline \multirow[t]{8}{*}{ Country } & Brazil & 27 & $14.8 \%$ \\
\hline & Canada & 11 & $6.0 \%$ \\
\hline & China & 24 & $13.2 \%$ \\
\hline & Greece & 10 & $5.5 \%$ \\
\hline & Italy & 18 & $9.9 \%$ \\
\hline & Netherlands & 10 & $5.5 \%$ \\
\hline & United Kingdom & 12 & $6.6 \%$ \\
\hline & Other & 70 & $38.5 \%$ \\
\hline \multirow[t]{5}{*}{ Continent } & Europe & 79 & $43.4 \%$ \\
\hline & North America & 19 & $10.4 \%$ \\
\hline & South America & 29 & $15.9 \%$ \\
\hline & Asia & 50 & $27.5 \%$ \\
\hline & Other & 5 & $2.8 \%$ \\
\hline \multirow[t]{2}{*}{ Affiliation } & University & 170 & $93.4 \%$ \\
\hline & Other & 12 & $6.6 \%$ \\
\hline \multirow[t]{3}{*}{ Number of authors } & $1-3$ & 53 & $29.1 \%$ \\
\hline & $4-6$ & 103 & $56.6 \%$ \\
\hline & $>6$ & 26 & $14.3 \%$ \\
\hline \multirow[t]{2}{*}{ Statistician involved } & No & 156 & $85.7 \%$ \\
\hline & Yes & 26 & $14.3 \%$ \\
\hline \multirow[t]{2}{*}{ Multicenter review team } & No & 81 & $44.5 \%$ \\
\hline & Yes & 101 & $55.5 \%$ \\
\hline \multirow[t]{2}{*}{ Funding received } & No & 141 & $77.5 \%$ \\
\hline & Yes & 41 & $22.5 \%$ \\
\hline \multirow[t]{2}{*}{ PRISMA citation } & No & 79 & $43.4 \%$ \\
\hline & Yes & 103 & $56.6 \%$ \\
\hline \multirow[t]{3}{*}{ Journal type } & Dental; orthodontic & 94 & $51.7 \%$ \\
\hline & Dental; non-orthodontic & 58 & $31.9 \%$ \\
\hline & Non-dental & 30 & $16.5 \%$ \\
\hline \multirow[t]{2}{*}{ Registered in PROSPERO } & No & 145 & $79.7 \%$ \\
\hline & Yes & 37 & $20.3 \%$ \\
\hline
\end{tabular}


Table 2. Fulfillment of AMSTAR items according to registration in PROSPERO. Results given as absolute and relative column percentages

\begin{tabular}{|c|c|c|c|c|c|}
\hline & & Not registered & Registered & & \\
\hline AMSTAR item & Answer & n (\%) & $n(\%)$ & $\mathbf{P}$ & Test \\
\hline \multirow[t]{3}{*}{ Item 1} & No & $104(71.7 \%)$ & $1(2.6 \%)$ & $<0.001$ & Fisher \\
\hline & Partly & $2(1.4 \%)$ & $0(0 \%)$ & & \\
\hline & Yes & $39(26.7 \%)$ & $36(97.3 \%)$ & & \\
\hline \multirow[t]{3}{*}{ Item 2} & No & $17(11.7 \%)$ & $2(5.4 \%)$ & 0.12 & Fisher \\
\hline & Partly & 28 (19.3\%) & $3(8.1 \%)$ & & \\
\hline & Yes & $100(69.0 \%)$ & $32(86.5 \%)$ & & \\
\hline \multirow[t]{3}{*}{ Item 3} & No & $3(2.1 \%)$ & $0(0 \%)$ & 0.45 & Fisher \\
\hline & Partly & $12(8.3 \%)$ & $1(2.7 \%)$ & & \\
\hline & Yes & $130(89.7 \%)$ & $36(97.3 \%)$ & & \\
\hline \multirow[t]{3}{*}{ Item 4} & No & 56 (38.6\%) & $9(24.3 \%)$ & 0.03 & $x^{2}$ \\
\hline & Partly & $21(14.5 \%)$ & $2(5.4 \%)$ & & \\
\hline & Yes & $68(46.9 \%)$ & $26(70.3 \%)$ & & \\
\hline \multirow[t]{3}{*}{ Item 5} & No & $3(2.1 \%)$ & $0(0 \%)$ & 1.00 & Fisher \\
\hline & Partly & $108(74.5 \%)$ & $28(75.7 \%)$ & & \\
\hline & Yes & $34(23.5 \%)$ & $9(24.3 \%)$ & & \\
\hline \multirow[t]{3}{*}{ Item 6} & No & $2(1.4 \%)$ & $0(0 \%)$ & 0.63 & Fisher \\
\hline & Partly & $0(0 \%)$ & $0(0 \%)$ & & \\
\hline & Yes & $143(98.6 \%)$ & $37(100.0 \%)$ & & \\
\hline \multirow[t]{3}{*}{ Item 7} & No & $22(15.2 \%)$ & $0(0 \%)$ & 0.005 & Fisher \\
\hline & Partly & $0(0 \%)$ & $0(0 \%)$ & & \\
\hline & Yes & $123(84.8 \%)$ & $37(100 \%)$ & & \\
\hline \multirow{3}{*}{ Item 8} & No & $26(17.9 \%)$ & $0(0 \%)$ & 0.002 & Fisher \\
\hline & Partly & $0(0 \%)$ & $0(0 \%)$ & & \\
\hline & Yes & 119 (82.1\%) & $37(100.0 \%)$ & & \\
\hline \multirow[t]{3}{*}{ Item 9} & No & $25(17.2 \%)$ & $4(10.8 \%)$ & 0.65 & Fisher \\
\hline & Partly & $2(1.4 \%)$ & $0(0 \%)$ & & \\
\hline & Yes & $118(81.4 \%)$ & $33(89.2 \%)$ & & \\
\hline \multirow[t]{3}{*}{ Item 10} & No & $85(58.6 \%)$ & $13(35.1 \%)$ & 0.02 & Fisher \\
\hline & Partly & $1(0.7 \%)$ & $0(0 \%)$ & & \\
\hline & Yes & $59(40.7 \%)$ & $24(64.9 \%)$ & & \\
\hline \multirow[t]{3}{*}{ Item 11} & No & $49(33.8 \%)$ & $13(35.1 \%)$ & 0.51 & Fisher \\
\hline & Partly & $0(0 \%)$ & $0(0 \%)$ & & \\
\hline & Yes & $96(66.2 \%)$ & $24(64.9 \%)$ & & \\
\hline
\end{tabular}


Table 3. Univariable and multivariable regression modelling with \% AMSTAR score as the dependent variable

\begin{tabular}{|c|c|c|c|}
\hline Factor & Category & b $(95 \%$ Cl) & $\mathbf{P}$ \\
\hline \multicolumn{4}{|l|}{ Univariable } \\
\hline \multirow[t]{2}{*}{ Registration in PROSPERO } & No & Referent & \\
\hline & Yes & $15.5(9.3,21.8)$ & $<0.001$ \\
\hline \multicolumn{4}{|l|}{ Multivariable } \\
\hline \multirow[t]{2}{*}{ Registration in PROSPERO } & No & Referent & \\
\hline & Yes & $6.6(1.0,12.3)$ & 0.02 \\
\hline Publication year & Per year & $-0.1(-1.8,1.7)$ & 0.94 \\
\hline No of authors (categorized) & & $0.1(-3.4,3.6)$ & 0.97 \\
\hline \multirow[t]{2}{*}{ Statistician involved } & No & Referent & \\
\hline & Yes & $6.6(0.4,12.8)$ & 0.04 \\
\hline \multirow[t]{2}{*}{ Multicenter author team } & No & Referent & \\
\hline & Yes & $0.1(-4.4,4.6)$ & 0.97 \\
\hline \multirow[t]{3}{*}{ Journal category } & Dental; general & Referent & \\
\hline & Dental; specialty & $5.3(0.2,10.3)$ & 0.04 \\
\hline & General medicine & $1.0(-5.7,7.6)$ & 0.78 \\
\hline \multirow{4}{*}{ Number of included studies } & $1-9$ & Referent & \\
\hline & $10-19$ & $-2.7(-7.8,2.5)$ & 0.31 \\
\hline & $20-29$ & $-1.7(-8.1,4.6)$ & 0.60 \\
\hline & $>30$ & $-7.5(-14.3,-0.6)$ & 0.03 \\
\hline \multirow[t]{2}{*}{ PRISMA citation } & No & Referent & \\
\hline & Yes & $6.2(1.4,10.9)$ & 0.01 \\
\hline \multirow[t]{2}{*}{ GRADE use } & No & Referent & \\
\hline & Yes & $11.8(6.6,17.0)$ & $<0.001$ \\
\hline \multirow[t]{2}{*}{ Flowdiagram included } & No & Referent & \\
\hline & Yes & $11.7(4.0,19.5)$ & 0.003 \\
\hline \multirow[t]{2}{*}{ Meta-analysis performed } & No & Referent & \\
\hline & Yes & $9.2(4.3,14.1)$ & $<0.001$ \\
\hline \multirow{2}{*}{ Significant results } & No & Referent & \\
\hline & Yes & $3.7(-1.3,8.6)$ & 0.14 \\
\hline
\end{tabular}

Abbreviations: b, unstandardized regression coefficient; Cl, confidence interval; 
Table 4. Differences in methodological characteristics of systematic reviews according to registration status

\begin{tabular}{|l|l|l|l|l|l|}
\hline & & Not registered & Registered & & \\
\hline Characteristic & & $\mathbf{n}(\%)$ & $\mathbf{n}(\%)$ & $\mathbf{P}$ & Test \\
\hline Statistician involved & No & $125(86.2 \%)$ & $31(83.8 \%)$ & 0.71 & $\mathrm{x}^{2}$ \\
\hline & Yes & $20(13.8 \%)$ & $6(16.2 \%)$ & & \\
\hline & & & & & \\
\hline PRISMA citation & No & $71(49.0 \%)$ & $8(21.6 \%)$ & 0.003 & $\mathrm{x}^{2}$ \\
\hline & Yes & $74(51.0 \%)$ & $29(78.4 \%)$ & & \\
\hline & & & & & \\
\hline GRADE used & No & $119(82.1 \%)$ & $22(59.5 \%)$ & 0.003 & $\mathrm{x}^{2}$ \\
\hline & Yes & $26(17.9 \%)$ & $15(40.5 \%)$ & & \\
\hline Flowdiagram included & & & & & \\
\hline & No & $16(11.0 \%)$ & $0(0 \%)$ & 0.05 & Fisher \\
\hline & Yes & $129(89.0 \%)$ & $37(100.0 \%)$ & & \\
\hline Included only RCTs & & & & & \\
\hline & No & $134(92.4 \%)$ & $35(94.6 \%)$ & 1.00 & Fisher \\
\hline & Yes & $11(7.6 \%)$ & $2(5.4 \%)$ & & \\
\hline Meta-analysis performed & No & $64(44.1 \%)$ & $9(24.3 \%)$ & 0.03 & $x^{2}$ \\
\hline & Yes & $81(55.9 \%)$ & $28(75.7 \%)$ & & \\
\hline Abbreviations: RCT, rand
\end{tabular}

Abbreviations: $\mathrm{RCT}$, randomized clinical trial. 


\section{FIGURE LEGENDS}

Fig. 1. Flowdiagram for the identification and selection of eligible systematic reviews in this study.

\section{Identification}

\section{Screening}

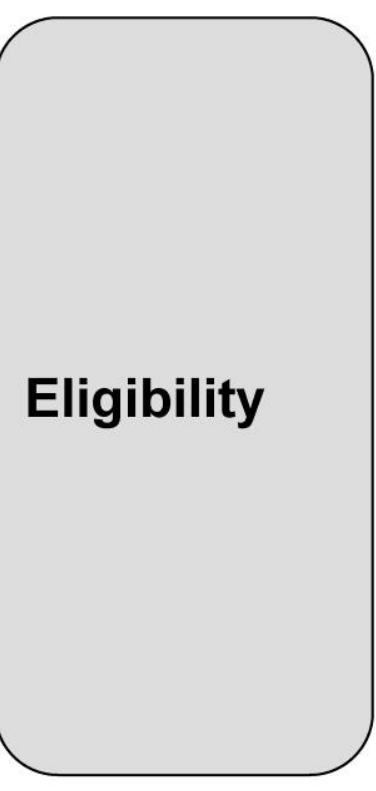

Records identified $(n=2141)$

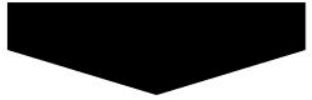

Records after duplicates removed $(n=1176)$

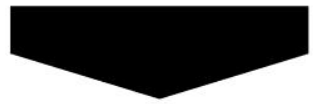

Records excluded $(n=994)$

- Missing fulltext $(n=16)$

- Not relevant ( $n=109)$

- Non-orthodontic subject $(n=681)$

- Not a systematic review $(n=39)$

- Published prior to $2012(n=127)$

- Withdrawn review $(n=1)$

- Registered not in PROSPERO $(n=1)$

- Duplicate publication $(n=1)$

- Published as thesis $(n=1)$

- Cochrane review $(n=18)$

Included $(\mathrm{n}=182)$ 
Fig. 2. Radar plot with the \% proportion of included systematic reviews that fulfill fully/partly each AMSTAR Item (It) according to registration status.

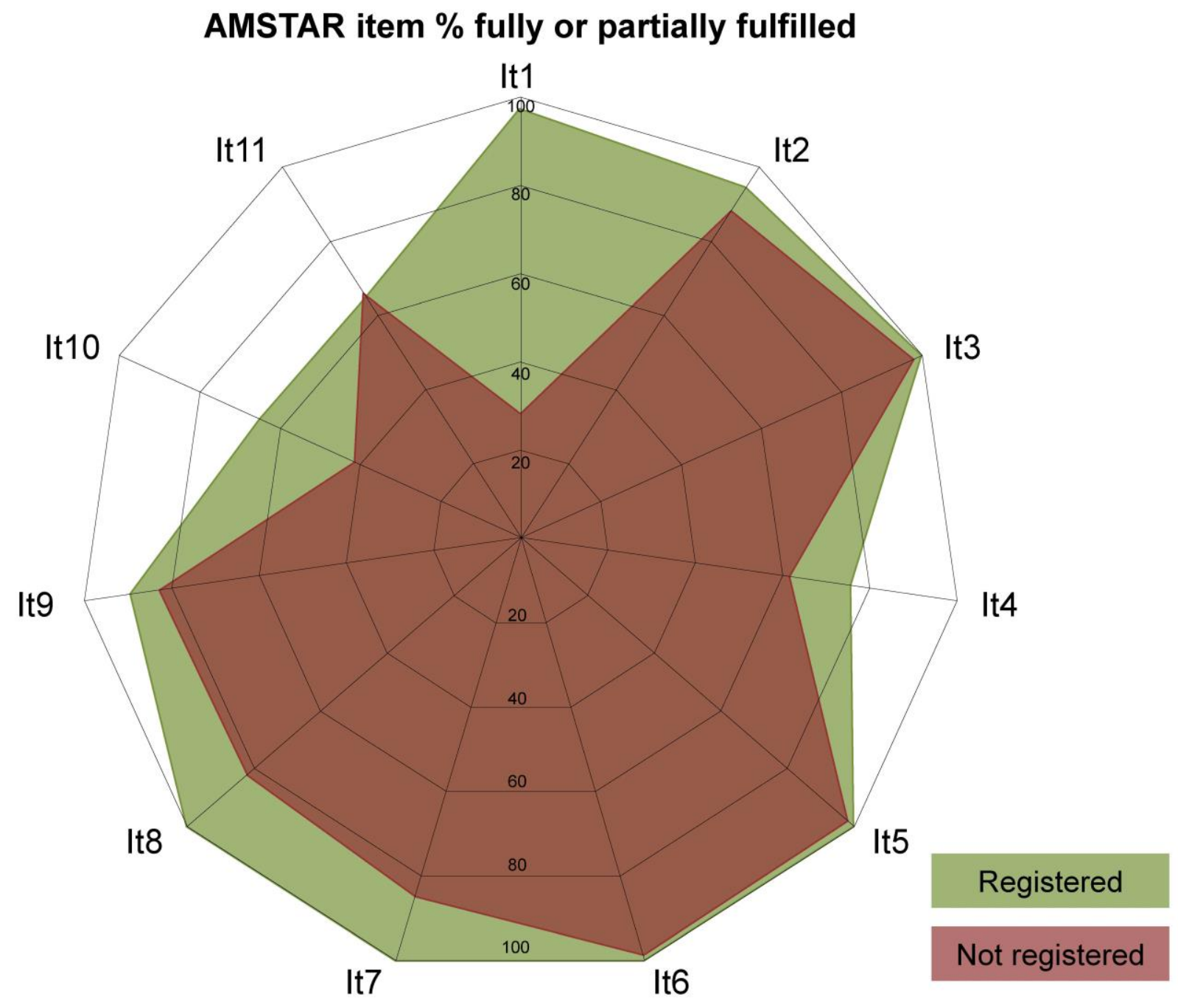




\section{Registration in PROSPERO of systematic review protocols was associated with increased review quality}

\section{APPENDICES}

Appendix A. Literature searches performed in all databases with their hits (search date January 10, 2017).

\begin{tabular}{|c|c|c|}
\hline Database & Search strategy & Hits \\
\hline $\begin{array}{l}\text { MEDLINE (via PubMed) } \\
\text { www.pubmed.gov }\end{array}$ & $\begin{array}{l}\text { (orthodon* OR orthognath* OR "dentofacial orthopedics" OR "tooth movement" OR "craniofacial growth" OR "growth } \\
\text { modification" OR multibracket OR malocclusion OR "fixed appliance" OR cleft* OR "functional appliance") AND } \\
\text { ("meta-analysis") }\end{array}$ & 593 \\
\hline $\begin{array}{l}\text { Cochrane Database of } \\
\text { Systematic Reviews } \\
\text { www.cochranelibrary.com }\end{array}$ & $\begin{array}{l}\text { (orthodon* OR orthognath* OR "dentofacial orthopedics" OR "tooth movement" OR "craniofacial growth" OR "growth } \\
\text { modification" OR multibracket OR malocclusion OR "fixed appliance" OR cleft* OR "functional appliance") }\end{array}$ & 64 \\
\hline $\begin{array}{l}\text { Cochrane Database of Abstracts } \\
\text { of Reviews of Effects } \\
\text { www.cochranelibrary.com }\end{array}$ & $\begin{array}{l}\text { (orthodon* OR orthognath* OR "dentofacial orthopedics" OR "tooth movement" OR "craniofacial growth" OR "growth } \\
\text { modification" OR multibracket OR malocclusion OR "fixed appliance" OR cleft* OR "functional appliance") }\end{array}$ & 149 \\
\hline $\begin{array}{l}\text { Embase } \\
\text { www.embase.com }\end{array}$ & $\begin{array}{l}\text { orthodon* OR orthognath* OR 'dentofacial orthopedics' OR 'tooth movement'/exp OR 'tooth movement' OR } \\
\text { 'craniofacial growth'/exp OR 'craniofacial growth' OR 'growth modification' OR multibracket OR 'malocclusion'/exp OR } \\
\text { malocclusion OR 'fixed appliance' OR cleft* OR 'functional appliance' AND ('meta-analysis'/exp OR 'meta-analysis') } \\
\text { AND [meta analysis]/lim AND [embase]/lim }\end{array}$ & 415 \\
\hline $\begin{array}{l}\text { Scopus } \\
\text { www.scopus.com }\end{array}$ & $\begin{array}{l}\text { (orthodon* OR orthognath* OR "dentofacial orthopedics" OR "tooth movement" OR "craniofacial growth" OR "growth } \\
\text { modification" OR multibracket OR malocclusion OR "fixed appliance" OR cleft* OR "functional appliance") AND } \\
\text { ("meta-analysis") }\end{array}$ & 581 \\
\hline $\begin{array}{l}\text { Web of Science } \\
\text { www.webofknowledge.com }\end{array}$ & $\begin{array}{l}\text { (orthodon* OR orthognath* OR "dentofacial orthopedics" OR "tooth movement" OR "craniofacial growth" OR "growth } \\
\text { modification" OR multibracket OR malocclusion OR "fixed appliance" OR cleft* OR "functional appliance") AND } \\
\text { ("meta-analysis") }\end{array}$ & 317 \\
\hline $\begin{array}{l}\text { Virtual Health Library } \\
\text { www.bvsalud.org/en/ }\end{array}$ & $\begin{array}{l}\text { (orthodon* OR orthognath* OR "dentofacial orthopedics" OR "tooth movement" OR "craniofacial growth" OR "growth } \\
\text { modification" OR multibracket OR malocclusion OR "fixed appliance" OR cleft* OR "functional appliance") AND } \\
\text { ("meta-analysis") }\end{array}$ & 22 \\
\hline
\end{tabular}


Appendix B. The 11 items of the AMSTAR tool used for the quality assessment of included systematic reviews.

\begin{tabular}{|l|}
\hline Item \\
\hline 1. Was an 'a priori' design provided? \\
\hline $\begin{array}{l}\text { 2. Was there duplicate study selection } \\
\text { and data extraction? }\end{array}$ \\
\hline
\end{tabular}

\section{Explanation; notes}

The research question and inclusion criteria should be established before the conduct of the review; Note: Need to refer to a protocol, ethics approval, or pre-determined/a priori published research objectives to score a "yes."

3. Was a comprehensive literature search performed?

2 people do study selection, 2 people do data extraction, consensus process or one person checks the other's work.

At least two electronic sources should be searched. The report must include years and databases used (e.g., Central, EMBASE,

and MEDLINE). Key words and/or MESH terms must be stated and where feasible the search strategy should be provided. All searches should be supplemented by consulting current contents, reviews, textbooks, specialized registers, or experts in the particular field of study, and by reviewing the references in the studies found; Note: If at least 2 sources + one supplementary strategy used, select "yes" (Cochrane register/Central counts as 2 sources; a grey literature search counts as supplementary). The authors should state that they searched for reports regardless of their publication type. The authors should state whether or not they excluded any reports (from the systematic review), based on their publication status, language etc; Note: If review

4. Was the status of publication (i.e. grey literature) used as an inclusion criterion? indicates that there was a search for "grey literature" or "unpublished literature," indicate "yes." SINGLE database, dissertations, conference proceedings, and trial registries are all considered grey for this purpose. If searching a source that contains both grey and non-grey, must specify that they were searching for grey/unpublished lit.

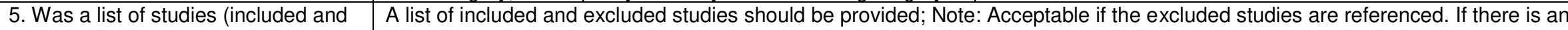
excluded) provided? electronic link to the list but the link is dead, select "no."

6. Were the characteristics of the included studies provided? In an aggregated form such as a table, data from the original studies should be provided on the participants, interventions and outcomes. The ranges of characteristics in all the studies analyzed e.g., age, race, sex, relevant socioeconomic data, disease status, duration, severity, or other diseases should be reported; Note: Acceptable if not in table format as long as they are described as above.

A priori' methods of assessment should be provided (e.g., for effectiveness studies if the author(s) chose to include only randomized, double-blind, placebo controlled studies, or allocation concealment as inclusion criteria); for other types of studies

7. Was the scientific quality of the included studies assessed and documented?

8. Was the scientific quality of the included studies used appropriately in formulating conclusions?

9. Were the methods used to combine the findings of studies appropriate? alternative items will be relevant; Note: Can include use of a quality scoring tool or checklist, e.g., Jadad scale, risk of bias, sensitivity analysis, etc., or a description of quality items, with some kind of result for EACH study ("low" or "high" is fine, as long as it is clear which studies scored "low" and which scored "high"; a summary score/range for all studies is not acceptable).

The results of the methodological rigor and scientific quality should be considered in the analysis and the conclusions of the review, and explicitly stated in formulating recommendations; Note: Might say something such as "the results should be interpreted with caution due to poor quality of included studies." Cannot score "yes" for this question if scored "no" for question 7.

For the pooled results, a test should be done to ensure the studies were combinable, to assess their homogeneity (i.e., Chisquared test for homogeneity, I2). If heterogeneity exists a random effects model should be used and/or the clinical appropriateness of combining should be taken into consideration (i.e., is it sensible to combine?); Note: Indicate "yes" if they mention or describe heterogeneity, i.e., if they explain that they cannot pool because of heterogeneity/variability between interventions.

10. Was the likelihood of publication bias assessed?

An assessment of publication bias should include a combination of graphical aids (e.g., funnel plot, other available tests) and/or statistical tests (e.g., Egger regression test, Hedges-Olken); Note: If no test values or funnel plot included, score "no". Score "yes" if mentions that publication bias could not be assessed because there were fewer than 10 included studies.

11. Was the conflict of interest

Potential sources of support should be clearly acknowledged in both the systematic review and the included studies; Note: To get included?

a "yes," must indicate source of funding or support for the systematic review AND for each of the included studies. 
Appendix C. Additional details for the statistical analysis.

-Variables 'country of origin' and 'geographical continent': countries with less than 10 systematic reviews and continents with less than 5 systematic reviews were collapsed into an 'Other' category. This was decided post hoc to enable more effective data presentation. From these two variable, only the 'geographical continent' variable was used in the regression models.

-Assumptions for the linear regression modelling were checked with the commands "estat imtest, white", "ovtest", "linktest", "vif", "predict e, resid", and "kdensity e, normal". This was planned a priori in the study protocol.

-The variables 'number of authors per review' and 'number of included primary studies per review' were transformed from continuous to categorical variables (1-3 authors; 4-6 authors; >6 authors / 1-9 studies; 10-19 studies; 20-29 studies; >30 studies) to relieve extreme data skewness. This was decided post hoc after inspection of graphs from the "avplots" command. 


\section{Appendix D. List of studies excluded/included in this assessment.}

\begin{tabular}{|c|c|c|}
\hline No & Paper & Exclusion reason ${ }^{\star}$ \\
\hline 1 & $\begin{array}{l}\text { Bergstrand F, Twetman S. Evidence for the efficacy of various methods of treating white-spot lesions after debonding of fixed orthodontic appliances. } \\
\text { Journal of clinical orthodontics : JCO. 2003;37(1):19-21. }\end{array}$ & Mising fulltext \\
\hline 2 & $\begin{array}{l}\text { Chen Y, Shu WN, He DQ. Effectiveness and safety of power chain versus nickel titanium coil springs in closing dental extraction space: A meta-analysis. } \\
\text { Chinese Journal of Evidence-Based Medicine. } 2012 ; 12(11): 1391-5 \text {. }\end{array}$ & Mising fulltext \\
\hline 3 & $\begin{array}{l}\text { Dai ML, Xiao M, Yu Z, Liu DX. [Effect of extraction and non-extraction treatment on frontal smiling esthetics: a meta-analysis]. Shanghai kou qiang yi xue = } \\
\text { Shanghai journal of stomatology. 2015;24(4):499-504. }\end{array}$ & Mising fulltext \\
\hline 4 & $\begin{array}{l}\text { Ge ZL, Jiao X, Tian JH, Yang KH. Clinical effectiveness of vacuum-formed versus Hawley retainers: A systematic review. Chinese Journal of Evidence- } \\
\text { Based Medicine. 2012;12(5):596-601. }\end{array}$ & Mising fulltext \\
\hline 5 & $\begin{array}{l}\text { Gerke B, Hiersche M, Jones J, Lewis P, Martin M. The effect of the timing of hard palate repair on maxillary growth in the patient with a unilateral cleft } \\
\text { lipand palate: A systematic review. Journal of Investigative Medicine. 2014;62(1):168. }\end{array}$ & Mising fulltext \\
\hline 6 & $\begin{array}{l}\text { Huo Y, } \mathrm{He} \mathrm{H} \text {, Guo Y, Hua F. Efficacy of low-level diode laser therapy on orthodontic pain management: A systematic review and meta-analysis. Medical } \\
\text { Journal of Wuhan University. 2016;37(3):506-11. }\end{array}$ & Mising fulltext \\
\hline 7 & $\begin{array}{l}\text { Jiao X, Tian J, Yang K, Ge Z. Clinical effectiveness of vacuum-formed versus Hawley retainers: a systematic review. Chinese Journal of Evidence-Based } \\
\text { Medicine. 2012; 12(5):[596-601 pp.]. }\end{array}$ & Mising fulltext \\
\hline 8 & $\begin{array}{l}\text { Liu ZP, Chen TT, Li GF, Jiang SC, Zou SJ. Meta analysis of soft tissue profile repair in patients treated with and without premolar extraction. Journal of } \\
\text { Clinical Rehabilitative Tissue Engineering Research. 2010;14(2):237-9. }\end{array}$ & Mising fulltext \\
\hline 9 & $\begin{array}{l}\text { Poletti L, Monti B, Esposito L, Farronato G. Effectiveness of functional appliances in class II malocclusion treatment. Part i. Mondo Ortodontico. } \\
\text { 2012;37(5):142-51. }\end{array}$ & Mising fulltext \\
\hline 10 & $\begin{array}{l}\text { Poletti L, Tripodi IM, Esposito L, Farronato G. Effectiveness of functional appliances in association with extraoral traction in class II malocclusion } \\
\text { treatment. Part II. Mondo Ortodontico. 2012;37(5):152-8. }\end{array}$ & Mising fulltext \\
\hline 11 & Poyak J. Effects of pacifiers on early oral development. International journal of orthodontics (Milwaukee, Wis). 2006;17(4):13-6. & Mising fulltext \\
\hline 12 & $\begin{array}{l}\text { Sonwane S, Shweta RK, Kumar BS, Shett RGK. Chronic congenital systemic disorder- a hurdle in orthodontic treatment plans: Meta analysis. } \\
\text { International Journal of Medical Research \& Health Sciences. 2016:5(6):239-47. }\end{array}$ & Mising fulltext \\
\hline 13 & Torlaschi R. Orthodontics and periodontics: A meta-analysis. Giornale dell'Odontoiatra. 2008;25(13):23. & Mising fulltext \\
\hline 14 & $\begin{array}{l}\text { Wang M, Guo Y, Jiang H. Effectiveness of topical fluoride on prevention of enamel demineralization during the orthodontic treatment in China: A } \\
\text { systematic review. Chinese Journal of Evidence-Based Medicine. 2013;13(7):875-84. }\end{array}$ & Mising fulltext \\
\hline 15 & $\begin{array}{l}\text { Zhang DP, Liu J, Liu Y, Sun N, Yi JC. [Influence of self-ligating and conventional brackets on dental arch width in non-extraction treatment: a meta } \\
\text { analysis]. Shanghai kou qiang yi xue = Shanghai journal of stomatology. 2014;23(3):367-72. }\end{array}$ & Mising fulltext \\
\hline 16 & $\begin{array}{l}\text { Zhuge XQ, Zheng Q, Xu X. Meta-analysis of curative effect of distraction osteogenesis surgery on craniofacial deformity secondary to cleft lip and palate. } \\
\text { Journal of Clinical Rehabilitative Tissue Engineering Research. 2010;14(7):1162-5. }\end{array}$ & Mising fulltext \\
\hline 17 & Abdallah MN, Flores-Mir C. Are interventions for accelerating orthodontic tooth movement effective? Evidence-based dentistry. 2014;15(4):116-7. & Not relevant to the study \\
\hline 18 & $\begin{array}{l}\text { Al-Jewair TS, Gaffar BO, Flores-Mir C. Quality assessment of systematic reviews on the efficacy of oral appliance therapy for adult and pediatric sleep- } \\
\text { disordered breathing. Journal of Clinical Sleep Medicine. } 2016 ; 12(8): 1175-83 \text {. }\end{array}$ & Not relevant to the study \\
\hline 19 & $\begin{array}{l}\text { Allareddy V, Lee MK, Shah A, Elangovan S, Lin CY. Association between study design and citation counts of articles published in the American Journal of } \\
\text { Orthodontics and Dentofacial Orthopedics and Angle Orthodontist. Orthodontics : the art and practice of dentofacial enhancement. 2012;13(1):184-91. }\end{array}$ & Not relevant to the study \\
\hline 20 & $\begin{array}{l}\text { Al-Riyami S, Moles DR, Cunningham SJ. Orthognathic treatment and temporomandibular disorders: A systematic review. Part 1. A new quality- } \\
\text { assessment technique and analysis of study characteristics and classifications. Am J Orthod Dentofacial Orthop 2009;136(5):624.e1-e15. }\end{array}$ & Not relevant to the study \\
\hline 21 & $\begin{array}{l}\text { BeGole EA, Sadowsky C. Methodologies for evaluating long-term stability of dental relationships after orthodontic treatment. Seminars in orthodontics. } \\
1999 ; 5(3): 142-50 \text {. }\end{array}$ & Not relevant to the study \\
\hline 22 & $\begin{array}{l}\text { Birchler FA, Kiliaridis S, Combescure C, Vazquez L. Dental age assessment on panoramic radiographs in a Swiss population: a validation study of two } \\
\text { prediction models. Dento maxillo facial radiology. } 2016 ; 45(1): 20150137 .\end{array}$ & Not relevant to the study \\
\hline 23 & $\begin{array}{l}\text { Böhmer AC, Ludwig KU, Knapp M, Steegers-Theunissen RP, Rubini M, Mossey PA, et al. Replication of genome-wide significant susceptibility factors for } \\
\text { nonsyndromic cleft lip with or without cleft palate in a European population: Support for 1p36, } 1 \text { p22.1 and 20q12. Medizinische Genetik. 2013;25(1):142. }\end{array}$ & Not relevant to the study \\
\hline 24 & $\begin{array}{l}\text { Böhmer AC, Nagarajan B, Ishorst N, Knapp M, Cotney JL, Nöthen MM, et al. Nonsyndromic cleft lip and palate: Identification of a causal element at } \\
\text { 13Q31. Medizinische Genetik. 2016;28(1):100. }\end{array}$ & Not relevant to the study \\
\hline 25 & Bondemark L, Ruf S. Randomized controlled trial: the gold standard or an unobtainable fallacy? Eur J Orthod 2015;37(5):457-61. & Not relevant to the study \\
\hline 26 & Bonito AJ, Lux L, Lohr KN. Authors' response [2]. Journal of periodontology. 2006;77(2):323-4. & Not relevant to the study \\
\hline 27 & $\begin{array}{l}\text { Boonacker CWB, Rovers MM, Browning GG, Hoes AW, Schilder AGM, Burton MJ. Background and introduction. Health Technology Assessment. } \\
\text { 2014;18(5):1-+. }\end{array}$ & Not relevant to the study \\
\hline 28 & $\begin{array}{l}\text { Bortolus R, Blom F, Filippini F, van Poppel MN, Leoncini E, de Smit DJ, et al. Prevention of congenital malformations and other adverse pregnancy } \\
\text { outcomes with 4.0 mg of folic acid: community-based randomized clinical trial in Italy and the Netherlands. BMC pregnancy and childbirth. 2014;14:166. }\end{array}$ & Not relevant to the study \\
\hline 29 & $\begin{array}{l}\text { Bykowski MR, Naran S, Winger DF, Losee JE. Abstract 116: the rate of oronasal fistula formation following primary cleft palate surg ery: a meta-analysis. } \\
\text { Plastic and reconstructive surgery. 2014;133(3 Suppl):132-3. }\end{array}$ & Not relevant to the study \\
\hline 30 & Chia M. Evidence not strong enough to advocate powered toothbrushes over manual for orthodontic patients. Evidence-based dentistry. 2008;9(3):78. & Not relevant to the study \\
\hline 31 & Cobourne MT. Finding the evidence is all in the methodology. J Orthod 2014;41(3):165-6. & Not relevant to the study \\
\hline 32 & $\begin{array}{l}\text { Cunningham Jr LL, Dodson TB, Feinberg SE, Le AD, Wohlford ME, Zuniga JR. } 2007 \text { Research Summit: At the Forefront of Innovation. Journal of Oral and } \\
\text { Maxillofacial Surgery. 2008;66(2):215-22. }\end{array}$ & Not relevant to the study \\
\hline 33 & $\begin{array}{l}\text { Danda AK. Re: Effectiveness of Postoperative Antibiotics in Orthognathic Surgery: A Meta-Analysis, by Danda and Ravi Response. Journal of Oral and } \\
\text { Maxillofacial Surgery. 2012;70(9):2024-5. }\end{array}$ & Not relevant to the study \\
\hline 34 & $\begin{array}{l}\text { D'Anto V, Bucci R, Franchi L, Rongo R, Michelotti A, Martina R. Class II functional orthopaedic treatment: a systematic review of systematic reviews. } \\
\text { Journal of oral rehabilitation. 2015;42(8):624-42. }\end{array}$ & Not relevant to the study \\
\hline 35 & $\begin{array}{l}\text { Dawson KH, Chigurupati R. Fixation of mandibular fractures: a tincture of science. Annals of the Royal Australasian College of Dental Surgeons. } \\
\text { 2002;16:118-22. }\end{array}$ & Not relevant to the study \\
\hline 36 & $\begin{array}{l}\text { De Vries N, Den Herder C, Hessel NS, Hoekema A. Treatment of obstructive sleep apnea syndrome in adults [7] (multiple letters). Nederlands Tijdschrift } \\
\text { voor Geneeskunde. 2004;148(5):250-1. }\end{array}$ & Not relevant to the study \\
\hline 37 & Dodson T. Efficacy of biodegradable osteofixation devices in oral and maxillofacial surgery remains inconclusive. Evidence-based dentistry. 2007;8(2):44. & Not relevant to the study \\
\hline 38 & Dodson TB. Corticosteroid administration in oral and orthognathic surgery. Evidence-based dentistry. 2011;12(2):49-50. & Not relevant to the study \\
\hline 39 & $\begin{array}{l}\text { Elkhadem A, Orabi N. Weak evidence suggests higher risk for bracket bonding failure with self-etch primer compared to conventional acid etch over } 12 \\
\text { months. Evidence-based dentistry. 2013;14(2):52-3. }\end{array}$ & Not relevant to the study \\
\hline 40 & Elkhadem A. Large overjet may double the risk of dental trauma. Evidence-based dentistry. 2015;16(2):56. & Not relevant to the study \\
\hline 41 & Espahbod C, Veitz-Keenan A. Tranexamic acid reduces intraoperative blood loss in orthognathic surgery. Evidence-based dentistry. 2014;15(2):63. & Not relevant to the study \\
\hline 42 & Fleming PS, DiBiase AT. Systematic reviews in orthodontics: what have we learned? International dental journal. 2008;58(1):10-4. & Not relevant to the study \\
\hline 43 & $\begin{array}{l}\text { Fleming PS, Johal A, Pandis N. The effectiveness of laceback ligatures during initial orthodontic alignment: a systematic review and meta-analysis Reply. } \\
\text { Eur J Orthod 2013;35(4):548-50. }\end{array}$ & Not relevant to the study \\
\hline 44 & $\begin{array}{l}\text { Fleming PS, Koletsi D, Pandis N. Blinded by PRISMA: are systematic reviewers focusing on PRISMA and ignoring other guidelines? PloS one. } \\
\text { 2014;9(5):e96407. }\end{array}$ & Not relevant to the study \\
\hline 45 & $\begin{array}{l}\text { Fleming PS, Koletsi D, Seehra J, Pandis N. Systematic reviews published in higher impact clinical journals were of higher quality. Journal of clinical } \\
\text { epidemiology. 2014;67(7):754-9. }\end{array}$ & Not relevant to the study \\
\hline 46 & $\begin{array}{l}\text { Fleming PS, Seehra J, Polychronopoulou A, Fedorowicz Z, Pandis N. Cochrane and non-Cochrane systematic reviews in leading orthodontic journals: a } \\
\text { quality paradigm? Eur J Orthod 2013;35(2):244-8. }\end{array}$ & Not relevant to the study \\
\hline 47 & Fleming PS. Accelerating orthodontic tooth movement using surgical and non-surgical approaches. Evidence-based dentistry. 2014;15(4):114-5. & Not relevant to the study \\
\hline 48 & $\begin{array}{l}\text { Fleming PS. Limited evidence suggests no difference in orthodontic attachment failure rates with the acid-etch technique and self-etch primers. Evidence- } \\
\text { based dentistry. 2014;15(2):48-9. }\end{array}$ & Not relevant to the study \\
\hline 49 & $\begin{array}{l}\text { Flores-Mir C, Major MP, Major PW. Search and selection methodology of systematic reviews in orthodontics (2000-2004). Am J Orthod Dentofacial Orthop } \\
\text { 2006;130(2):214-7. }\end{array}$ & Not relevant to the study \\
\hline 50 & Flores-Mir C. Bonded molar tubes associated with higher failure rate than molar bands. Evidence-based dentistry. 2011;12(3):84. & Not relevant to the study \\
\hline 51 & Flores-Mir C. Little evidence to guide initial arch wire choice for fixed appliance therapy. Evidence-based dentistry. 2014;15(4):112-3. & Not relevant to the study \\
\hline 52 & Flores-Mir C. No reliable evidence to guide initial arch wire choice for fixed appliance therapy. Evidence-based dentistry. 2013;14(4):114-5. & Not relevant to the study \\
\hline
\end{tabular}




\begin{tabular}{|c|c|c|}
\hline 53 & $\begin{array}{l}\text { Fox N, Ross Segal G, Schiffman PH, Tuncay OC. Longer orthodontic treatment may result in greater external apical root resorption: What are the } \\
\text { treatment-related aetiological factors of external apical root resorption of the maxillary incisor? Evidence-based dentistry. } 2005 ; 6(1): 21 .\end{array}$ & Not relevant to the study \\
\hline 54 & Fox N. Longer orthodontic treatment may result in greater external apical root resorption. Evidence-based dentistry. 2005;6(1):21. & Not relevant to the study \\
\hline 55 & $\begin{array}{l}\text { Fricton J. Current evidence providing clarity in management of temporomandibular disorders: summary of a systematic review of randomized clinical trials } \\
\text { for intra-oral appliances and occlusal therapies. The journal of evidence-based dental practice. } 2006 ; 6(1): 48-52 \text {. }\end{array}$ & Not relevant to the study \\
\hline 56 & $\begin{array}{l}\text { Fricton JR, Ouyang W, Nixdorf DR, Schiffman EL, Velly AM, Look JO. Critical appraisal of methods used in randomized controlled trials of treatments for } \\
\text { temporomandibular disorders. Journal of orofacial pain. 2010;24(2):139-51. }\end{array}$ & Not relevant to the study \\
\hline 57 & Gioka C, Eliades T. Materials-induced variation in the torque expression of preadjusted appliances. Am J Orthod Dentofacial Orthop 2004;125(3):323-8. & Not relevant to the study \\
\hline 58 & Girardi TLD. Análise cefalométrica de Arnett - revisão de literatura. Ortho Sci, Orthod sci pract. 2011;3(13):488-93. & Not relevant to the study \\
\hline 59 & $\begin{array}{l}\text { Hani TB, O'Connell AC, Duane B. Casein phosphopeptide-amorphous calcium phosphate products in caries prevention. Evidence-based dentistry. } \\
\text { 2016;17(2):46-7. }\end{array}$ & Not relevant to the study \\
\hline 60 & $\begin{array}{l}\text { Hanke BA, Motschall E, Turp JC. Association between orthopedic and dental findings: what level of evidence is available? J Orofac Orthop 2007;68(2):91- } \\
107 .\end{array}$ & Not relevant to the study \\
\hline 61 & $\begin{array}{l}\text { Harman NL, Bruce IA, Kirkham JJ, Tierney S, Callery P, O'Brien K, et al. The Importance of Integration of Stakeholder Views in Core Outcome Set } \\
\text { Development: Otitis Media with Effusion in Children with Cleft Palate. PloS one. } 2015 ; 10(6): \text { :0129514. }\end{array}$ & Not relevant to the study \\
\hline 62 & $\begin{array}{l}\text { He W, Li C, Zou S. Reply to comments on: "Efficacy of low-level laser therapy in the management of orthodontic pain: a systematic review and meta- } \\
\text { analysis". Lasers in medical science. 2015;30(2):941-2. }\end{array}$ & Not relevant to the study \\
\hline 63 & How Kau C. Orthodontic retention regimes: will we ever have the answer? Evidence-based dentistry. 2006;7(4):100. & Not relevant to the study \\
\hline 64 & Ismail Al, Bader JD. Evidence-based dentistry in clinical practice. Journal of the American Dental Association. 2004;135(1):78-83. & Not relevant to the study \\
\hline 65 & $\begin{array}{l}\text { Jamilian A, Cannavale R, Piancino MG, Eslami S, Perillo L. Methodological quality and outcome of systematic reviews reporting on orthopaedic treatment } \\
\text { for class III malocclusion: Overview of systematic reviews. J Orthod 2016;43(2):102-20. }\end{array}$ & Not relevant to the study \\
\hline 66 & $\begin{array}{l}\text { Javidi H, Benson P. The impact of malocclusion and its treatment on the oral health related quality of life of adults, assessed using the Oral Health Impact } \\
\text { Profile (OHIP-14). Evidence-based dentistry. } 2015 ; 16(2): 57-8 \text {. }\end{array}$ & Not relevant to the study \\
\hline 67 & Kalha A. Can I intrude? Evidence-based dentistry. 2007;8(1):17. & Not relevant to the study \\
\hline 68 & Kalha A. Orthognathic treatment and temporomandibular disorders - part 1. Evidence-based dentistry. 2010;11(3):82-3. & Not relevant to the study \\
\hline 69 & Kalha A. Orthognathic treatment and temporomandibular disorders - part 2. Evidence-based dentistry. 2010;11(3):84-5. & Not relevant to the study \\
\hline 70 & Kalha AS. Hawley or vacuum-formed retainers following orthodontic treatment? Evidence-based dentistry. 2014;15(4):110-1. & Not relevant to the study \\
\hline 71 & Kalha AS. Is anchorage reinforcement with implants effective in orthodontics? Evidence-based dentistry. 2008;9(1):13-4. & Not relevant to the study \\
\hline 72 & $\begin{array}{l}\text { Kalha AS. Topical fluorides and decalcification around fixed orthodontic appliances: Which topical fluoride preparations are best able to prevent } \\
\text { decalcification around fixed orthodontic appliances? Evidence-based dentistry. 2006;7(2):38-9. }\end{array}$ & Not relevant to the study \\
\hline 73 & $\begin{array}{l}\text { Kanavakis G, Dombroski MM, Malouf DP, Athanasiou AE. Demographic characteristics of systematic reviews, meta-analyses, and randomized controlled } \\
\text { trials in orthodontic journals with impact factor. Eur J Orthod 2016;38(1):57-65. }\end{array}$ & Not relevant to the study \\
\hline 74 & $\begin{array}{l}\text { Kau CH. Orthodontic retention regimes: Will we ever have the answer?: How effective are different retention procedures in maintaining tooth position after } \\
\text { treatment by orthodontic appliances? Evidence-based dentistry. 2006; } 7(4): 100 \text {. }\end{array}$ & Not relevant to the study \\
\hline 75 & $\begin{array}{l}\text { Koletsi D, Fleming PS, Eliades T, Pandis N. The evidence from systematic reviews and meta-analyses published in orthodontic literature. Where do we } \\
\text { stand? Eur J Orthod 2015;37(6):603-9. }\end{array}$ & Not relevant to the study \\
\hline 76 & $\begin{array}{l}\text { Koletsi D, Valla K, Fleming PS, Chaimani A, Pandis N. Assessment of publication bias required improvement in oral health systematic reviews. Journal of } \\
\text { clinical epidemiology. 2016;76:118-24. }\end{array}$ & Not relevant to the study \\
\hline 77 & $\begin{array}{l}\text { Kuijpers MA, Kuijpers-Jagtman AM. [Orthodontics in general practice 3. Angle Class II/1 malocclusion: one-phase treatment treatment preferred to two- } \\
\text { phase treatment]. Nederlands tijdschrift voor tandheelkunde. 2008;115(1):22-8. }\end{array}$ & Not relevant to the study \\
\hline 78 & $\begin{array}{l}\text { Long H, Jian F, Lai W. Weak evidence supports the short-term benefits of orthopaedic treatment for Class III malocclusion in children. Evidence-based } \\
\text { dentistry. 2014;15(1):21-2. }\end{array}$ & Not relevant to the study \\
\hline 79 & Long H, Lai W. No reliable evidence for the association between dental crowding and caries. Evidence-based dentistry. 2013;14(1):12. & Not relevant to the study \\
\hline 80 & $\begin{array}{l}\text { Long H, Zhou Y, Lai W. The effectiveness of laceback ligatures during initial orthodontic alignment: a systematic review and meta-analysis. Eur J Orthod } \\
2013 ; 35(4): 547-8 \text {. }\end{array}$ & Not relevant to the study \\
\hline 81 & $\begin{array}{l}\text { Madurantakam P. Fixed or removable function appliances for Class II malocclusions. Evidence-based dentistry. 2016;17(2):52-3. } \\
\text { Mal- }\end{array}$ & Not relevant to the study \\
\hline 82 & Maia LC, Antonio AG. Systematic reviews in dental research. A guideline. The Journal of clinical pediatric dentistry. 2012;37(2):117-24. & Not relevant to the study \\
\hline 83 & Mattos CT, Ruellas AC. Systematic review and meta-analysis: what are the implications in the clinical practice? Dental Press J Orthod 2015;20(1):17-9. & Not relevant to the study \\
\hline 84 & McGuinness N. Fixed functional appliances show definite skeletal and dental changes in the short term. Eur J Orthod 2016;38(2):127-8. & Not relevant to the study \\
\hline 85 & $\begin{array}{l}\text { Meursinge Reynders R, Ladu L, Ronchi L, Di Girolamo N, de Lange J, Roberts N, et al. Insertion torque recordings for the diagnosis of contact between } \\
\text { orthodontic mini-implants and dental roots: protocol for a systematic review. Systematic reviews. 2015;4:39. }\end{array}$ & Not relevant to the study \\
\hline 86 & Mossey P. Epidemiology underpinning research in the aetiology of orofacial clefts. Orthodontics \& craniofacial research. $2007 ; 10(3): 114-20$. & Not relevant to the study \\
\hline 87 & $\begin{array}{l}\text { O'Neill JRS. Functional appliances and mandibular growth }- \text { is there an effect?: Do functional appliances enhance mandibular growth in the treatment of } \\
\text { skeletal Class II malocclusions? Evidence-based dentistry. } 2004 ; 5(3): 74 \text {. }\end{array}$ & Not relevant to the study \\
\hline 88 & O'Brien K. Longer treatment times with self-ligated orthodontic brackets. Evidence-based dentistry. 2014;15(3):92. & Not relevant to the study \\
\hline 89 & O'Neill J. Do lip bumpers work? Evidence-based dentistry. 2009;10(2):48-9. & Not relevant to the study \\
\hline 90 & $\begin{array}{l}\text { Pandis N, Fleming PS, Worthington H, Dwan K, Salanti G. Discrepancies in Outcome Reporting Exist Between Protocols and Published Oral Health } \\
\text { Cochrane Systematic Reviews. PloS one. 2015;10(9):e0137667. }\end{array}$ & Not relevant to the study \\
\hline 91 & $\begin{array}{l}\text { Pandis N, Fleming PS, Worthington H, Salanti G. The Quality of the Evidence According to GRADE Is Predominantly Low or Very Low in Oral Health } \\
\text { Systematic Reviews. PloS one. } 2015 ; 10(7): 00131644 \text {. }\end{array}$ & Not relevant to the study \\
\hline 92 & $\begin{array}{l}\text { Pandis N. Randomized clinical trials (RCTs) and systematic reviews (SRs) in the context of evidence-based orthodontics (EBO). Seminars in orthodontics. } \\
\text { 2013;19(3):142-57. }\end{array}$ & Not relevant to the study \\
\hline 93 & Papadopoulos MA, Gkiaouris I. A critical evaluation of meta-analyses in orthodontics. Am J Orthod Dentofacial Orthop 2007;131(5):589-99. & Not relevant to the study \\
\hline 94 & Papadopoulos MA. Meta-analyses and orthodontic evidence-based clinical practice in the 21 century. The open dentistry journal. 2010;4:92-123. & Not relevant to the study \\
\hline 95 & Papadopoulos MA. Meta-analysis in evidence-based orthodontics. Orthodontics \& craniofacial research. 2003;6(2):112-26. & Not relevant to the study \\
\hline 96 & $\begin{array}{l}\text { Papageorgiou SN, Antonoglou GN, Tsiranidou E, Jepsen S, Jager A. Bias and small-study effects influence treatment effect estimates: a meta- } \\
\text { epidemiological study in oral medicine. Journal of clinical epidemiology. 2014;67(9):984-92. }\end{array}$ & Not relevant to the study \\
\hline 97 & $\begin{array}{l}\text { Papageorgiou SN, Dimitraki D, Coolidge T, Kotsanos N. Publication bias \& small-study effects in pediatric dentistry meta-analyses. The journal of } \\
\text { evidence-based dental practice. } 2015 ; 15(1): 8-24 \text {. }\end{array}$ & Not relevant to the study \\
\hline 98 & $\begin{array}{l}\text { Papageorgiou SN, Gölz L, Jäger A, Eliades T, Bourauel C, Afrashtehfar KI. Evidence regarding lingual fixed orthodontic appliances' therapeutic and } \\
\text { adverse effects is insufficient. Evidence-based dentistry. 2016;17(2):54-5. }\end{array}$ & Not relevant to the study \\
\hline 99 & Papageorgiou SN, Koretsi V, Jager A. Bias from historical control groups used in orthodontic research: a meta-epidemiological study. Eur J Orthod 2016. & Not relevant to the study \\
\hline 100 & $\begin{array}{l}\text { Papageorgiou SN, Papadopoulos MA, Athanasiou AE. Assessing small study effects and publication bias in orthodontic meta-analyses: A meta- } \\
\text { epidemiological study. Clinical oral investigations. 2014;18(4):1031-44. }\end{array}$ & Not relevant to the study \\
\hline 101 & $\begin{array}{l}\text { Papageorgiou SN, Papadopoulos MA, Athanasiou AE. Reporting characteristics of meta-analyses in orthodontics: methodological assessment and } \\
\text { statistical recommendations. Eur J Orthod 2014;36(1):74-85. }\end{array}$ & Not relevant to the study \\
\hline 102 & $\begin{array}{l}\text { Papageorgiou SN, Tsiranidou E, Antonoglou GN, Deschner J, Jager A. Choice of effect measure for meta-analyses of dichotomous outcomes influenced } \\
\text { the identified heterogeneity and direction of small-study effects. Journal of clinical epidemiology. 2015;68(5):534-41. }\end{array}$ & Not relevant to the study \\
\hline 103 & $\begin{array}{l}\text { Papageorgiou SN, Xavier GM, Cobourne MT. Basic study design influences the results of orthodontic clinical investigations. Journal of clinical } \\
\text { epidemiology. 2015;68(12):1512-22. }\end{array}$ & Not relevant to the study \\
\hline 104 & Papageorgiou SN. Meta-analysis for orthodontists: Part I--How to choose effect measure and statistical model. J Orthod 2014;41(4):317-26. & Not relevant to the study \\
\hline 105 & Papageorgiou SN. Meta-analysis for orthodontists: Part II--Is all that glitters gold? Journal of orthodontics. 2014;41(4):327-36. & Not relevant to the study \\
\hline 106 & Pickett F. Editor's Consensus Report: Periodontitis and Atherosclerotic Cardiovascular Disease. American Journal of Cardiology. 2010;105(3):424-5. & Not relevant to the study \\
\hline 107 & $\begin{array}{l}\text { Proffit WR. EVIDENCE AND CLINICAL DECISIONS: Asking the Right Questions to Obtain Clinically Useful Answers. Seminars in orthodontics. } \\
\text { 2013:19(3). }\end{array}$ & Not relevant to the study \\
\hline 108 & $\begin{array}{l}\text { Rana SS, Kharbanda OP. Letter to editor on "Efficiency of bimaxillary advancement surgery in increasing the volume of the upper airways: a systematic } \\
\text { review of observational studies and meta-analysis". Eur Arch Otorhinolaryngol } 2016 \text {. }\end{array}$ & Not relevant to the study \\
\hline 109 & $\begin{array}{l}\text { Reynders RM, de Lange J. Moderate quality evidence that surgical anchorage more effective than conventional anchorage during orthodontic treatment. } \\
\text { Evidence-based dentistry. 2014;15(4):108-9. }\end{array}$ & Not relevant to the study \\
\hline 110 & $\begin{array}{l}\text { Rinchuse DJ, Rinchuse DJ, Kandasamy S, Ackerman MB. Deconstructing evidence in orthodontics: making sense of systematic reviews, randomized } \\
\text { clinical trials, and meta-analyses. World journal of orthodontics. 2008;9(2):167-76. }\end{array}$ & Not relevant to the study \\
\hline
\end{tabular}




\begin{tabular}{|c|c|c|}
\hline 111 & Roberts CT, Semb G, Shaw WC. Strategies for the advancement of surgical methods in cleft lip and palate. Cleft Palate Craniofac J 1991;28(2):141-9. & Not relevant to the study \\
\hline 112 & $\begin{array}{l}\text { Rosario HD, Oliveira GM, Freires IA, Matos FS, Paranhos LR. Reply to the comment on: "Efficiency of bimaxillary advancement surgery in increasing the } \\
\text { volume of the upper airways: a systematic review of observational studies and meta-analysis". Eur Arch Otorhinolaryngol } 2016 \text {. }\end{array}$ & Not relevant to the study \\
\hline 113 & Ruiz M. Evidence-based orthodontics or the paradigm shift. International orthodontics. 2011;9(1):1-19. & Not relevant to the study \\
\hline 114 & $\begin{array}{l}\text { Saltaji H, Armijo-Olivo S, Cummings GG, Amin M, Flores-Mir C. Methodological characteristics and treatment effect sizes in oral health randomised } \\
\text { controlled trials: Is there a relationship? Protocol for a meta-epidemiological study. BMJ open. 2014;4(2):e004527. }\end{array}$ & Not relevant to the study \\
\hline 115 & $\begin{array}{l}\text { Saltaji H, Cummings GG, Armijo-Olivo S, Major MP, Amin M, Major PW, et al. A descriptive analysis of oral health systematic reviews published 1991- } \\
\text { 2012: cross sectional study. PloS one. 2013;8(9):e74545. }\end{array}$ & Not relevant to the study \\
\hline 116 & $\begin{array}{l}\text { Seehra J, Pandis N, Koletsi D, Fleming PS. Use of quality assessment tools in systematic reviews was varied and inconsistent. Journal of clinical } \\
\text { epidemiology. 2016;69:179-84.e5. }\end{array}$ & Not relevant to the study \\
\hline 117 & $\begin{array}{l}\text { Shadrick V, Walker M. Facemask therapy between ages six to ten years may lead to short term improvements for Class III malocclusions. Evidence-based } \\
\text { dentistry. 2013;14(4):112-3. }\end{array}$ & Not relevant to the study \\
\hline 118 & $\begin{array}{l}\text { Sygouros A, Acar A. Evidence-based orthodontics: Appraisal of the methodologies of systematic reviews and meta-analyses in controversial areas of } \\
\text { orthodontics. Journal of the World Federation of Orthodontists. 2013;2(3):e117-e22. }\end{array}$ & Not relevant to the study \\
\hline 119 & $\begin{array}{l}\text { Tan SK, Lo J, Zwahlen RA. Re: Effectiveness of postoperative antibiotics in orthognathic surgery: a meta-analysis, by Danda and Ravi. J Oral Maxillofac } \\
\text { Surg. 2012;70(9):2023-4; author reply 4-5. }\end{array}$ & Not relevant to the study \\
\hline 120 & $\begin{array}{l}\text { Tuncay OC, Tulloch JF. Apparatus criticus: methods used to evaluate growth modification in Class II malocclusion. Am J Orthod Dentofacial Orthop } \\
\text { 1992;102(6):531-6. }\end{array}$ & Not relevant to the study \\
\hline 121 & Turpin DL. Improve care with clinical practice guidelines. Am J Orthod Dentofacial Orthop 2009;136(4):475-6. & Not relevant to the study \\
\hline 122 & Wells M. Review suggests that cleft lip and palate patients have more caries. Evidence-based dentistry. 2014;15(3):79. & Not relevant to the study \\
\hline 123 & $\begin{array}{l}\text { Werner EF, Savitz DA, Janevic TM, Ehsanipoor RM, Thung SF, Funai EF, et al. Infants' MTHFR polymorphisms and nonsyndromic orofacial clefts } \\
\text { susceptibility: A meta-analysis based on } 17 \text { case-control studies: Editorial comment. Obstetrical and Gynecological Survey. 2013;68(1):12-3. }\end{array}$ & Not relevant to the study \\
\hline 124 & $\begin{array}{l}\text { Wlodarczyk BJ, Palacios AM, George TM, Finnell RH. Antiepileptic drugs and pregnancy outcomes: Editorial comment. Obstetrical and Gynecological } \\
\text { Survey. 2012;67(12):770-2. }\end{array}$ & Not relevant to the study \\
\hline 125 & $\begin{array}{l}\text { Yan B. Comments on: "efficacy of low-level laser therapy in the management of orthodontic pain: a systematic review and meta-analysis". Lasers in } \\
\text { medical science. } 2014 ; 29(4): 1531 .\end{array}$ & Not relevant to the study \\
\hline 126 & $\begin{array}{l}\text { [No authors] Abstracts of the 16th International Congress of the Hungarian Society for Microbiology. Acta Microbiologica et Immunologica Hungarica. } \\
2011 ; 58 \text {. }\end{array}$ & Non-orthodontic subject \\
\hline 127 & [No authors] Abstracts Presented at the Laryngology and Rhinology Section Meetings 2013. Journal of Laryngology and Otology. 2014;128(5). & Non-orthodontic subject \\
\hline 128 & $\begin{array}{l}\text { Abariga SA, Whitcomb BW. Periodontitis and gestational diabetes mellitus: A systematic review and meta-analysis of observational studies. BMC } \\
\text { pregnancy and childbirth. } 2016 ; 16(1) \text {. }\end{array}$ & Non-orthodontic subject \\
\hline 129 & $\begin{array}{l}\text { Abdolmaleky HM, Thiagalingam S, Wilcox M. Genetics and epigenetics in major psychiatric disorders: Dilemmas, achievements, applications, and future } \\
\text { scope. American Journal of PharmacoGenomics. } 2005 ; 5(3): 149-60 \text {. }\end{array}$ & Non-orthodontic subject \\
\hline 130 & $\begin{array}{l}\text { Abramovits W, Boguniewicz M, Paller AS, Whitaker-Worth DL, Prendergast MM, Tokar M, et al. The economics of topical immunomodulators for the } \\
\text { treatment of atopic dermatitis. PharmacoEconomics. 2005;23(6):543-66. }\end{array}$ & Non-orthodontic subject \\
\hline 131 & $\begin{array}{l}\text { Abreu LG, Elyasi M, Badri P, Paiva SM, Flores-Mir C, Amin M. Factors associated with the development of dental caries in children and adolescents in } \\
\text { studies employing the life course approach: a systematic review. European journal of oral sciences. } 2015 .\end{array}$ & Non-orthodontic subject \\
\hline 132 & $\begin{array}{l}\text { Acke FRE, Dhooge IJM, Malfait F, De Leenheer EMR. Hearing impairment in Stickler syndrome: A systematic review. Orphanet Journal of Rare Diseases. } \\
2012 ; 7(1) \text {. }\end{array}$ & Non-orthodontic subject \\
\hline 133 & $\begin{array}{l}\text { Akram Z, Abduljabbar T, Abu Hassan MI, Javed F, Vohra F. Cytokine profile in chronic periodontitis patients with and without obesity: A systematic review } \\
\text { and meta-analysis. Disease markers. 2016;2016. }\end{array}$ & Non-orthodontic subject \\
\hline 134 & $\begin{array}{l}\text { Akram Z, Safii SH, Vaithilingam RD, Baharuddin NA, Javed F, Vohra F. Efficacy of non-surgical periodontal therapy in the management of chronic } \\
\text { periodontitis among obese and non-obese patients: a systematic review and meta-analysis. Clinical oral investigations. 2016;20(5):903-14. }\end{array}$ & Non-orthodontic subject \\
\hline 135 & $\begin{array}{l}\text { Aldrigui JM, Jabbar NS, Bonecker M, Braga MM, Wanderley MT. Trends and associated factors in prevalence of dental trauma in Latin America and } \\
\text { Caribbean: a systematic review and meta-analysis. Community dentistry and oral epidemiology. } 2014 ; 42(1): 30-42 \text {. }\end{array}$ & Non-orthodontic subject \\
\hline 136 & Alexander LM. Desirable therapeutic characteristics of an optimal antihypertensive agent. Drugs. 2006;66(9):1239-52. & Non-orthodontic subject \\
\hline 137 & $\begin{array}{l}\text { Al-Hamdan K, Eber R, Sarment D, Kowalski C, Wang HL. Guided tissue regeneration-based root coverage: Meta-analysis. Journal of periodontology. } \\
\text { 2003;74(10):1520-33. }\end{array}$ & Non-orthodontic subject \\
\hline 138 & $\begin{array}{l}\text { Al-Jewair TS, Al-Jasser R, Almas K. Periodontitis and obstructive sleep apnea's bidirectional relationship: a systematic review and meta-analysis. Sleep } \\
\text { and Breathing. } 2015 ; 19(4): 1111-20 \text {. }\end{array}$ & Non-orthodontic subject \\
\hline 139 & $\begin{array}{l}\text { Al-Khamis A, McCallum I, King PM, Bruce J. Healing by primary versus secondary intention after surgical treatment for pilonidal sinus. Cochrane } \\
\text { Database Syst Rev 2010(1):Cd006213. }\end{array}$ & Non-orthodontic subject \\
\hline 140 & $\begin{array}{l}\text { Allagh KP, Shamanna BR, Murthy GV, Ness AR, Doyle P, Neogi SB, et al. Birth prevalence of neural tube defects and orofacial clefts in India: a } \\
\text { systematic review and meta-analysis. PloS one. } 2015 ; 10(3): e 0118961 .\end{array}$ & Non-orthodontic subject \\
\hline 141 & $\begin{array}{l}\text { Al-Moraissi E, Ellis E. Surgical management of anterior mandibular fractures: a systematic review and meta-analysis. Database of Abstracts of Reviews of } \\
\text { Effects. 2014; (2):[2507.e1-.e11 pp.]. }\end{array}$ & Non-orthodontic subject \\
\hline 142 & $\begin{array}{l}\text { Al-Moraissi EA, Al-Hendi EA. Are bicortical screw and plate osteosynthesis techniques equal in providing skeletal stability with the bilateral sagittal split } \\
\text { osteotomy when used for mandibular advancement surgery? A systematic review and meta-analysis. International journal of oral and maxillofacial surgery. } \\
2016 ; 45(10): 1195-200 \text {. }\end{array}$ & Non-orthodontic subject \\
\hline 143 & $\begin{array}{l}\text { Al-Moraissi EA, Ellis E, 3rd. Biodegradable and Titanium Osteosynthesis Provide Similar Stability for Orthognathic Surgery. J Oral Maxillofac Surg. } \\
\text { 2015;73(9):1795-808. }\end{array}$ & Non-orthodontic subject \\
\hline 144 & $\begin{array}{l}\text { Al-Moraissi EA, Ellis E, 3rd. Surgical treatment of adult mandibular condylar fractures provides better outcomes than closed treatment: a systematic review } \\
\text { and meta-analysis. J Oral Maxillofac Surg. } 2015 ; 73(3): 482-93 \text {. }\end{array}$ & Non-orthodontic subject \\
\hline 145 & $\begin{array}{l}\text { Al-Moraissi EA, Ellis E. Bilateral Sagittal Split Ramus Osteotomy Versus Distraction Osteogenesis for Advancement of the Retrognathic Mandible. Journal } \\
\text { of Oral and Maxillofacial Surgery. 2015;73(8):1564-74. }\end{array}$ & Non-orthodontic subject \\
\hline 146 & $\begin{array}{l}\text { Al-Moraissi EA, Ellis E. Is There a Difference in Stability or Neurosensory Function Between Bilateral Sagittal Split Ramus Osteotomy and Intraoral } \\
\text { Vertical Ramus Osteotomy for Mandibular Setback? Journal of Oral and Maxillofacial Surgery. } 2015 ; 73(7): 1360-71 .\end{array}$ & Non-orthodontic subject \\
\hline 147 & $\begin{array}{l}\text { Al-Moraissi EA, Ellis E. Surgical management of anterior mandibular fractures: a systematic review and meta-analysis. J Oral Maxillofac Surg. } \\
2014 ; 72(12): 2507 . e 1-11 .\end{array}$ & Non-orthodontic subject \\
\hline 148 & $\begin{array}{l}\text { Al-Moraissi EA, Ellis E. What method for management of unilateral mandibular angle fractures has the lowest rate of postoperative complications? a } \\
\text { systematic review and meta-analysis. Journal of Oral and Maxillofacial Surgery. } 2014 ; 72(11): 2197-211 \text {. }\end{array}$ & Non-orthodontic subject \\
\hline 149 & $\begin{array}{l}\text { Al-Moraissi EA, El-Sharkawy TM, El-Ghareeb TI, Chrcanovic BR. Three-dimensional versus standard miniplate fixation in the management of mandibular } \\
\text { angle fractures: a systematic review and meta-analysis. International journal of oral and maxillofacial surgery. } 2014 ; 43(6): 708-16 \text {. }\end{array}$ & Non-orthodontic subject \\
\hline 150 & $\begin{array}{l}\text { Al-Moraissi EA, El-Sharkawy TM, Mounair RM, EI-Ghareeb TI. A systematic review and meta-analysis of the clinical outcomes for various surgical } \\
\text { modalities in the management of temporomandibular joint ankylosis. International journal of oral and maxillofacial surgery. 2015;44(4):470-82. }\end{array}$ & Non-orthodontic subject \\
\hline 151 & $\begin{array}{l}\text { Al-Moraissi EA. Open versus arthroscopic surgery for the management of internal derangement of the temporomandibular joint: a meta-analysis of the } \\
\text { literature. International journal of oral and maxillofacial surgery. } 2015 ; 44(6): 763-70 \text {. }\end{array}$ & Non-orthodontic subject \\
\hline 152 & $\begin{array}{l}\text { Alsaad AM, Chaudhry SA, Koren G. First trimester exposure to topiramate and the risk of oral clefts in the offspring: A systematic review and meta- } \\
\text { analysis. Reproductive toxicology (Elmsford, NY). 2015;53:45-50. }\end{array}$ & Non-orthodontic subject \\
\hline 153 & $\begin{array}{l}\text { Ammari MM, Soviero VM, da Silva Fidalgo TK, Lenzi M, Ferreira DM, Mattos CT, et al. Is non-cavitated proximal lesion sealing an effective method for } \\
\text { caries control in primary and permanent teeth? A systematic review and meta-analysis. Journal of dentistry. 2014;42(10):1217-27. }\end{array}$ & Non-orthodontic subject \\
\hline 154 & Amrute KV, Moldwin RM. Pharmacotherapy of interstitial cystitis in women. Women's Health. 2007;3(1):63-72. & Non-orthodontic subject \\
\hline 155 & Anderson GD, Miller JW. The newer antiepileptic drugs: Their collective role and defining characteristics. Formulary. 2001;36(2):114-35. & Non-orthodontic subject \\
\hline 156 & Anderson NK, Jayaratne YS. Methodological challenges when performing a systematic review. Eur J Orthod 2015;37(3):248-50. & Non-orthodontic subject \\
\hline 157 & $\begin{array}{l}\text { Andrade MR, Antunes LA, Soares RM, Leao AT, Maia LC, Primo LG. Lower dental caries prevalence associated to chronic kidney disease: a systematic } \\
\text { review. Pediatric nephrology (Berlin, Germany). 2014;29(5):771-8. }\end{array}$ & Non-orthodontic subject \\
\hline 158 & $\begin{array}{l}\text { Angeletaki F, Gkogkos A, Papazoglou E, Kloukos D. Direct versus indirect inlay/onlay composite restorations in posterior teeth. A systematic review and } \\
\text { meta-analysis. Journal of dentistry. 2016;53:12-21. }\end{array}$ & Non-orthodontic subject \\
\hline 159 & $\begin{array}{l}\text { Antiel RM, Jacobson RM, Fischer PR. Ethics for the pediatrician: A brave new pediatrics? Managing the desire for better children through biotechnological } \\
\text { enhancement. Pediatrics in Review. 2012;33(2):e13-7. }\end{array}$ & Non-orthodontic subject \\
\hline 160 & $\begin{array}{l}\text { Antonarakis GS, Christou P. Quantitative evaluation of neurosensory disturbance after bilateral sagittal split osteotomy using Semmes-Weinstein } \\
\text { monofilaments: a systematic review. J Oral Maxillofac Surg. } 2012 ; 70(12): 2752-60 \text {. }\end{array}$ & Non-orthodontic subject \\
\hline
\end{tabular}




\begin{tabular}{|c|c|c|}
\hline 161 & $\begin{array}{l}\text { Antonarakis GS, Palaska PK, Herzog G. Caries prevalence in non-syndromic patients with cleft lip and/or palate: a meta-analysis. Caries research. } \\
2013 ; 47(5): 406-13 \text {. }\end{array}$ & Non-orthodontic subject \\
\hline 162 & $\begin{array}{l}\text { Antonarakis GS, Patel RN, Tompson B. Oral health-related quality of life in non-syndromic cleft lip and/or palate patients: a systematic review. Community } \\
\text { dental health. } 2013 ; 30(3): 189-95 .\end{array}$ & Non-orthodontic subject \\
\hline 163 & $\begin{array}{l}\text { Antonarakis GS, Tsiouli K, Christou P. Mesiodistal tooth size in non-syndromic unilateral cleft lip and palate patients: a meta-analysis. Clinical oral } \\
\text { investigations. } 2013 ; 17(2): 365-77 \text {. }\end{array}$ & Non-orthodontic subject \\
\hline 164 & Antonio MDDG, Elizabeth AY, Alberto MA. Brain Abscess. Revista Mexicana de Neurociencia. 2010;11(1):63-70. & Non-orthodontic subject \\
\hline 165 & $\begin{array}{l}\text { Antonoglou GN, Sandor GK, Koidou VP, Papageorgiou SN. Non-syndromic and syndromic keratocystic odontogenic tumors: systematic review and meta- } \\
\text { analysis of recurrences. J Craniomaxillofac Surg 2014;42(7):e364-71. }\end{array}$ & Non-orthodontic subject \\
\hline 166 & $\begin{array}{l}\text { Araujo MM, Martins CC, Costa LC, Cota LO, Faria RL, Cunha FA, et al. Association between depression and periodontitis: a systematic review and meta- } \\
\text { analysis. Journal of clinical periodontology. } 2016 ; 43(3): 216-28 \text {. }\end{array}$ & Non-orthodontic subject \\
\hline 167 & $\begin{array}{l}\text { Arias-Irimia O, Barona-Dorado C, Santos-Marino JA, Martínez-Rodríguez N, Martínez-González JM. Meta-analisis of the etiology of odontogenic maxillary } \\
\text { sinusitis. Medicina oral, patologia oral y cirugia bucal. 2010;15(1):e70-e3. }\end{array}$ & Non-orthodontic subject \\
\hline 168 & $\begin{array}{l}\text { Ariyan S, Martin J, Lal A, Cheng D, Borah GL, Chung KC, et al. Antibiotic prophylaxis for preventing surgical-site infection in plastic surgery: an evidence- } \\
\text { based consensus conference statement from the American Association of Plastic Surgeons. Plastic and reconstructive surgery. 2015;135(6):1723-39. }\end{array}$ & Non-orthodontic subject \\
\hline 169 & $\begin{array}{l}\text { Armalaite J, Lopatiene K. Lateral teleradiography of the head as a diagnostic tool used to predict obstructive sleep apnea. Dento maxillo facial radiology. } \\
2016 ; 45(1): 20150085 \text {. }\end{array}$ & Non-orthodontic subject \\
\hline 170 & $\begin{array}{l}\text { Armijo-Olivo S, da Costa BR, Cummings GG, Ha C, Fuentes J, Saltaji H, et al. PEDro or Cochrane to Assess the Quality of Clinical Trials? A Meta- } \\
\text { Epidemiological Study. PloS one. 2015;10(7):e0132634. }\end{array}$ & Non-orthodontic subject \\
\hline 171 & $\begin{array}{l}\text { Armijo-Olivo S, Ospina M, da Costa BR, Egger M, Saltaji H, Fuentes J, et al. Poor reliability between Cochrane reviewers and blinded external reviewers } \\
\text { when applying the Cochrane risk of bias tool in physical therapy trials. PloS one. } 2014 ; 9(5): e 96920 .\end{array}$ & Non-orthodontic subject \\
\hline 172 & $\begin{array}{l}\text { Armijo-Olivo S, Pitance L, Singh V, Neto F, Thie N, Michelotti A. Effectiveness of Manual Therapy and Therapeutic Exercise for Temporomandibular } \\
\text { Disorders: Systematic Review and Meta-Analysis. Physical therapy. 2016;96(1):9-25. }\end{array}$ & Non-orthodontic subject \\
\hline 173 & $\begin{array}{l}\text { Armijo-Olivo S, Saltaji H, Da Costa BR, Fuentes J, Ha C, Cummings GG. What is the influence of randomization sequence generation and allocation } \\
\text { concealment on treatment effects of physical therapy trials? A meta-epidemiological study. BMJ open. } 2015 ; 5(9) \text {. }\end{array}$ & Non-orthodontic subject \\
\hline 174 & Ash MM. Occlusion: reflections on science and clinical reality. The Journal of prosthetic dentistry. 2003;90(4):373-84. & Non-orthodontic subject \\
\hline 175 & $\begin{array}{l}\text { Ashley PF, Parekh S, Moles DR, Anand P, Behbehani A. Preoperative analgesics for additional pain relief in children and adolescents having dental } \\
\text { treatment. Cochrane Database Syst Rev 2012(9):Cd008392. }\end{array}$ & Non-orthodontic subject \\
\hline 176 & $\begin{array}{l}\text { Ashley PF, Parekh S, Moles DR, Anand P, MacDonald LC. Preoperative analgesics for additional pain relief in children and adolescents having dental } \\
\text { treatment. Cochrane Database Syst Rev 2016(8):Cd008392. }\end{array}$ & Non-orthodontic subject \\
\hline 177 & $\begin{array}{l}\text { Astatkie A, Demissie M, Berhane Y. The association of khat (catha edulis) chewing and orodental health: A systematic review and meta-analysis. South } \\
\text { African Medical Journal. 2014;104(11):773-9. }\end{array}$ & Non-orthodontic subject \\
\hline 178 & Atieh MA. Photodynamic therapy as an adjunctive treatment for chronic periodontitis: A meta-analysis. Lasers in medical science. 2010;25(4):605-13. & Non-orthodontic subject \\
\hline 179 & $\begin{array}{l}\text { Austin J. Meeting Highlights: Lawson Wilkins Pediatric Endocrine Society (PES) Annual Meeting, Denver Colorado, USA. Pediatric Endocrinology } \\
\text { Reviews. 2011;9(1):481-5. }\end{array}$ & Non-orthodontic subject \\
\hline 180 & $\begin{array}{l}\text { Avila WM, Pordeus IA, Paiva SM, Martins CC. Breast and Bottle Feeding as Risk Factors for Dental Caries: A Systematic Review and Meta-Analysis. PloS } \\
\text { one. 2015;10(11):e0142922. }\end{array}$ & Non-orthodontic subject \\
\hline 181 & Azarpazhooh A. Is there a link between oral health and diabetes? Canadian Journal of Diabetes. 2014;38:S52. & Non-orthodontic subject \\
\hline 182 & $\begin{array}{l}\text { Badovinac RL, Werler MM, Williams PL, Kelsey KT, Hayes C. Folic acid-containing supplement consumption during pregnancy and risk for oral clefts: a } \\
\text { meta-analysis. Birth defects research Part A, Clinical and molecular teratology. 2007;79(1):8-15. }\end{array}$ & Non-orthodontic subject \\
\hline 183 & Bagga A, Mantan M. Nephrotic syndrome in children. Indian Journal of Medical Research. 2005;122(1):13-28. & Non-orthodontic subject \\
\hline 184 & $\begin{array}{l}\text { Bahekar AA, Singh S, Saha S, Molnar J, Arora R. The prevalence and incidence of coronary heart disease is significantly increased in periodontitis: A } \\
\text { meta-analysis. American Heart Journal. 2007;154(5):830-7. }\end{array}$ & Non-orthodontic subject \\
\hline 185 & $\begin{array}{l}\text { Bała MM, Leśniak W, Strzeszyński } Ł \text {. Efficacy of pharmacological methods used for treating tobacco dependence: Meta-analysis. Polskie Archiwum } \\
\text { Medycyny Wewnetrznej. 2008;118(1-2):20-8. }\end{array}$ & Non-orthodontic subject \\
\hline 186 & $\begin{array}{l}\text { Baldwin C, Parsons TJ. Dietary advice and nutritional supplements in the management of illness-related malnutrition: systematic review. Clinical Nutrition. } \\
2004 ; 23(6): 1267-79 \text {. }\end{array}$ & Non-orthodontic subject \\
\hline 187 & Banner NR. Tacrolimus: In heart transplant recipients - A viewpoint by Nicholas R. Banner. Drugs. 2006;66(17):2281. & Non-orthodontic subject \\
\hline 188 & $\begin{array}{l}\text { Baumgart DC, Sandborn WJ. Inflammatory bowel disease: clinical aspects and established and evolving therapies. Lancet (London, England). } \\
\text { 2007;369(9573):1641-57. }\end{array}$ & Non-orthodontic subject \\
\hline 189 & $\begin{array}{l}\text { Beaty TH, Taub MA, Scott AF, Murray JC, Marazita ML, Schwender H, et al. Confirming genes influencing risk to cleft lip with/without cleft palate in a } \\
\text { case-parent trio study. Human genetics. 2013;132(7):771-81. }\end{array}$ & Non-orthodontic subject \\
\hline 190 & $\begin{array}{l}\text { Bell JC, Raynes-Greenow C, Turner RM, Bower C, Nassar N, O'Leary CM. Maternal alcohol consumption during pregnancy and the risk of orofacial clefts } \\
\text { in infants: a systematic review and meta-analysis. Paediatric and perinatal epidemiology. } 2014 ; 28(4): 322-32 \text {. }\end{array}$ & Non-orthodontic subject \\
\hline 191 & $\begin{array}{l}\text { Belmonte FM, Macedo CR, Day PF, Saconato H, Fernandes MTV. Interventions for treating traumatised permanent front teeth: luxated (dislodged) teeth. } \\
\text { Cochrane Database of Systematic Reviews. 2013; (4). Available from: http://onlinelibrary.wiley.com/doi/10.1002/14651858.CD006203.pub2/abstract }\end{array}$ & Non-orthodontic subject \\
\hline 192 & $\begin{array}{l}\text { Berkey CS, Hoaglin DC, Antczak-Bouckoms A, Mosteller F, Colditz GA. Meta-analysis of multiple outcomes by regression with random effects. Statistics } \\
\text { in Medicine. } 1998 ; 17(22): 2537-50 \text {. }\end{array}$ & Non-orthodontic subject \\
\hline 193 & $\begin{array}{l}\text { Berner T, Essig H, Schumann P, Blumer M, Lanzer M, Rucker M, et al. Closed versus open treatment of mandibular condylar process fractures: A meta- } \\
\text { analysis of retrospective and prospective studies. J Craniomaxillofac Surg 2015;43(8):1404-8. }\end{array}$ & Non-orthodontic subject \\
\hline 194 & $\begin{array}{l}\text { Bessell A, Hooper L, Shaw WC, Reilly S, Reid J, Glenny AM. Feeding interventions for growth and development in infants with cleft lip, cleft palate or cleft } \\
\text { lip and palate. Cochrane Database Syst Rev } 2011(2): C d 003315 \text {. }\end{array}$ & Non-orthodontic subject \\
\hline 195 & $\begin{array}{l}\text { Bessell A, Sell D, Whiting P, Roulstone S, Albery L, Persson M, et al. Speech and language therapy interventions for children with cleft palate: A } \\
\text { systematic review. Cleft Palate-Craniofacial Journal. 2013;50(1):e1-e17. }\end{array}$ & Non-orthodontic subject \\
\hline 196 & Bhasin DK, Siyad I. Variceal bleeding and portal hypertension: New lights on old horizon. Endoscopy. 2004;36(2):120-9. & Non-orthodontic subject \\
\hline 197 & Binder A, Baron R, Schattschneider J, Wasner G. What do the concepts carry into clinical practice? Nervenheilkunde. 2004;23(5):287-91. & Non-orthodontic subject \\
\hline 198 & Birks J, Grimley Evans J, lakovidou V, Tsolaki M, Holt FE. Rivastigmine for Alzheimer's disease. Cochrane Database Syst Rev $2009(2): C d 001191$. & Non-orthodontic subject \\
\hline 199 & $\begin{array}{l}\text { Birks J, Harvey RJ. Donepezil for dementia due to Alzheimer's disease. Cochrane Database of Systematic Reviews. 2006; (1). Available from: } \\
\text { http://onlinelibrary.wiley.com/doi/10.1002/14651858.CD001190.pub2/abstract }\end{array}$ & Non-orthodontic subject \\
\hline 200 & $\begin{array}{l}\text { Birks J, Wilcock GK. Velnacrine for Alzheimer's disease. Cochrane Database of Systematic Reviews. 2004; (2). Available from: } \\
\text { http://onlinelibrary.wiley.com/doi/10.1002/14651858.CD004748/abstract }\end{array}$ & Non-orthodontic subject \\
\hline 201 & Birks JS, Grimley Evans J. Rivastigmine for Alzheimer's disease. Cochrane Database Syst Rev 2015(4):Cd001191. & Non-orthodontic subject \\
\hline 202 & $\begin{array}{l}\text { Birks JS. Cholinesterase inhibitors for Alzheimer's disease. Cochrane Database of Systematic Reviews. 2006; (1). Available from: } \\
\text { http://onlinelibrary.wiley.com/doi/10.1002/14651858.CD005593/abstract }\end{array}$ & Non-orthodontic subject \\
\hline 203 & $\begin{array}{l}\text { Bjorn AM, Ehrenstein V, Nohr EA, Norgaard M. Use of inhaled and oral corticosteroids in pregnancy and the risk of malformations or miscarriage. Basic \& } \\
\text { clinical pharmacology \& toxicology. 2015;116(4):308-14. }\end{array}$ & Non-orthodontic subject \\
\hline 204 & Blake PG. Growth hormone and malnutrition in dialysis patients. Peritoneal Dialysis International. 1995;15(6):210-6. & Non-orthodontic subject \\
\hline 205 & $\begin{array}{l}\text { Blanco R, Colombo A, Pardo R, Suazo J. Maternal biomarkers of methylation status and non-syndromic orofacial cleft risk: a meta-analysis. International } \\
\text { journal of oral and maxillofacial surgery. } 2016 ; 45(11): 1323-32 \text {. }\end{array}$ & Non-orthodontic subject \\
\hline 206 & $\begin{array}{l}\text { Blanco R, Colombo A, Suazo J. Maternal obesity is a risk factor for orofacial clefts: a meta-analysis. The British journal of oral \& maxillofacial surgery. } \\
\text { 2015;53(8):699-704. }\end{array}$ & Non-orthodontic subject \\
\hline 207 & $\begin{array}{l}\text { Bluestone CD. Studies in otitis media: Children's Hospital of Pittsburgh-University of Pittsburgh Progress Report - 2004. Laryngoscope. 2004;114(11 III):1- } \\
26 .\end{array}$ & Non-orthodontic subject \\
\hline 208 & Bodiguel E, Bensa C, Brassat D, Laplaud D, Le Page E, Ouallet JC, et al. Multiple sclerosis and pregnancy. Revue Neurologique. 2014;170(4):247-65. & Non-orthodontic subject \\
\hline 209 & $\begin{array}{l}\text { Bonito AJ, Lux L, Lohr KN. Impact of local adjuncts to scaling and root planing in periodontal disease therapy: A systematic review. Journal of } \\
\text { periodontology. } 2005 ; 76(8): 1227-36 \text {. }\end{array}$ & Non-orthodontic subject \\
\hline 210 & $\begin{array}{l}\text { Bonnot O, Vollset SE, Godet PF, d'Amato T, Dalery J, Robert E. [In utero exposure to benzodiazepine. Is there a risk for anal atresia with lorazepam?]. } \\
\text { L'Encephale. } 2003 ; 29(6): 553-9 .\end{array}$ & Non-orthodontic subject \\
\hline 211 & $\begin{array}{l}\text { Bookman LB, Melton KR, Pan BS, Bender PL, Chini BA, Greenberg JM, et al. Neonates with tongue-based airway obstruction: a systematic review. } \\
\text { Otolaryngology--head and neck surgery : official journal of American Academy of Otolaryngology-Head and Neck Surgery. 2012;146(1):8-18. }\end{array}$ & Non-orthodontic subject \\
\hline 212 & $\begin{array}{l}\text { Boonacker CW, Rovers MM, Browning GG, Hoes AW, Schilder AG, Burton MJ. Adenoidectomy with or without grommets for children with otitis media: an } \\
\text { individual patient data meta-analysis. Health technology assessment (Winchester, England). } 2014 ; 18(5): 1-118 \text {. }\end{array}$ & Non-orthodontic subject \\
\hline
\end{tabular}




\begin{tabular}{|c|c|c|}
\hline 213 & $\begin{array}{l}\text { Borrie FR, Bearn DR, Innes NP, Iheozor-Ejiofor Z. Interventions for the cessation of non-nutritive sucking habits in children. Cochrane Database Syst Rev } \\
2015(3) \text { :Cd008694. }\end{array}$ & Non-orthodontic subject \\
\hline 214 & $\begin{array}{l}\text { Botto LD, Olney RS, Erickson JD. Vitamin Supplements and the Risk for Congenital Anomalies Other Than Neural Tube Defects. American Journal of } \\
\text { Medical Genetics - Seminars in Medical Genetics. 2004;125 C(1):12-21. }\end{array}$ & Non-orthodontic subject \\
\hline 215 & $\begin{array}{l}\text { Boutin A, Demers S, Roberge S, Roy-Morency A, Chandad F, Bujold E. Treatment of periodontal disease and prevention of preterm birth: Systematic } \\
\text { review and meta-analysis. American Journal of Perinatology. 2013;30(7):537-44. }\end{array}$ & Non-orthodontic subject \\
\hline 216 & $\begin{array}{l}\text { Bove R, Alwan S, Friedman JM, Hellwig K, Houtchens M, Koren G, et al. Management of multiple sclerosis during pregnancy and the reproductive years. } \\
\text { Obstetrics and Gynecology. 2014;124(6):1157-68. }\end{array}$ & Non-orthodontic subject \\
\hline 217 & $\begin{array}{l}\text { Boyle P, Koechlin A, Autier P. A systematic review with meta-analysis of fluoridated mouthwash use for the prevention of dental caries. Oral Diseases. } \\
2014 ; 20(\mathrm{~S} 1): 27-34 \text {. }\end{array}$ & Non-orthodontic subject \\
\hline 218 & Boyle P, Koechlin A, Autier P. A systematic review with meta-analysis of mouthwash use for the prevention of gingivitis. Oral Diseases. 2014;20(S1):22-6. & Non-orthodontic subject \\
\hline 219 & $\begin{array}{l}\text { Boyle P, Koechlin A, Autier P. A systematic review with meta-analysis of mouthwash use for the prevention of supragingival plaques and gingivitis: } \\
\text { Objectives, methods, data retrieval and trial characteristics. Oral Diseases. } 2014 ; 20(\mathrm{~S} 1): 7-16 \text {. }\end{array}$ & Non-orthodontic subject \\
\hline 220 & $\begin{array}{l}\text { Bramham K, Soh MC, Nelson-Piercy C. Pregnancy and renal outcomes in lupus nephritis: An update and guide to management. Lupus. } \\
\text { 2012;21(12):1271-83. }\end{array}$ & Non-orthodontic subject \\
\hline 221 & $\begin{array}{l}\text { Brignardello-Petersen R, Carrasco-Labra A, Araya I, Yanine N, Cordova JL, Villanueva J. Antibiotic prophylaxis for preventing infectious complications in } \\
\text { orthognathic surgery. Cochrane Database of Systematic Reviews. 2015; (1). }\end{array}$ & Non-orthodontic subject \\
\hline 222 & $\begin{array}{l}\text { Bueno Torcato L, Junqueira Zuim PR, Atili Brandini D, Falcón-Antenucci RM. Terapéutica alternativa asociada al bruxismo: revisión de literatura. Acta } \\
\text { Odontol Venez. 2014;52(3). }\end{array}$ & Non-orthodontic subject \\
\hline 223 & $\begin{array}{l}\text { Bührer C. In newborns, oral or rectal paracetamol fails to reduce procedural pain, whereas intravenous paracetamol reduces morphine requirements after } \\
\text { major surgery. Evidence-Based Medicine. } 2016 ; 21(3): 93 \text {. }\end{array}$ & Non-orthodontic subject \\
\hline 224 & $\begin{array}{l}\text { Burrowes JD, Van Houten G. Use of alternative medicine by patients with stage } 5 \text { chronic kidney disease. Advances in Chronic Kidney Disease. } \\
2005 ; 12(3): 312-25 \text {. }\end{array}$ & Non-orthodontic subject \\
\hline 225 & $\begin{array}{l}\text { Busby A, Armstrong B, Dolk H, Armstrong N, Haeusler M, Berghold A, et al. Preventing neural tube defects in Europe: A missed opportunity. Reproductive } \\
\text { Toxicology. } 2005 ; 20(3): 393-402 \text {. }\end{array}$ & Non-orthodontic subject \\
\hline 226 & $\begin{array}{l}\text { Butali A, Little J, Chevrier C, Cordier S, Steegers-Theunissen R, Jugessur A, et al. Folic acid supplementation use and the MTHFR C677T polymorphism } \\
\text { in orofacial clefts etiology: An individual participant data pooled-analysis. Birth defects research Part A, Clinical and molecular teratology. 2013;97(8):509- } \\
\text { 14. }\end{array}$ & Non-orthodontic subject \\
\hline 227 & $\begin{array}{l}\text { Bykowski MR, Naran S, Winger DG, Losee JE. The Rate of Oronasal Fistula Following Primary Cleft Palate Surgery: A Meta-Analysis. Cleft Palate } \\
\text { Craniofac J 2015;52(4):e81-7. }\end{array}$ & Non-orthodontic subject \\
\hline 228 & $\begin{array}{l}\text { Camacho M, Certal V, Abdullatif J, Zaghi S, Ruoff CM, Capasso R, et al. Myofunctional therapy to treat obstructive sleep apnea: A systematic review and } \\
\text { meta-analysis. Sleep. 2015;38(5):669-75. }\end{array}$ & Non-orthodontic subject \\
\hline 229 & $\begin{array}{l}\text { Camacho M, Teixeira J, Abdullatif J, Acevedo JL, Certal V, Capasso R, et al. Maxillomandibular Advancement and Tracheostomy for Morbidly Obese } \\
\text { Obstructive Sleep Apnea: A Systematic Review and Meta-analysis. Otolaryngology-Head and Neck Surgery. 2015;152(4):619-30. }\end{array}$ & Non-orthodontic subject \\
\hline 230 & $\begin{array}{l}\text { Cao J, Kong L, Meng F, Zhang Y, Shen Y. Risk factors for new vertebral compression fractures after vertebroplasty: a meta-analysis. ANZ journal of } \\
\text { surgery. 2016;86(7-8):549-54. }\end{array}$ & Non-orthodontic subject \\
\hline 231 & $\begin{array}{l}\text { Caprilli R, Gassull MA, Escher JC, Moser G, Munkholm P, Forbes A, et al. European evidence based consensus on the diagnosis and management of } \\
\text { Crohn's disease: Special situations. Gut. 2006;55(SUPPL. 1):i36-i58. }\end{array}$ & Non-orthodontic subject \\
\hline 232 & $\begin{array}{l}\text { Carinci F, Pezzetti F, Scapoli L, Martinelli M, Carinci P, Tognon M. Genetics of nonsyndromic cleft lip and palate: a review of international studies and data } \\
\text { regarding the Italian population. Cleft Palate Craniofac J } 2000 ; 37(1): 33-40 \text {. }\end{array}$ & Non-orthodontic subject \\
\hline 233 & $\begin{array}{l}\text { Carlson L, Hatcher KW, Vander Burg R. Elevated infant mortality rates among oral cleft and isolated oral cleft cases: a meta-analysis of studies from } 1943 \\
\text { to 2010. Cleft Palate Craniofac J 2013;50(1):2-12. }\end{array}$ & Non-orthodontic subject \\
\hline 234 & Carter MJ, Lobo AJ, Travis SPL. Guidelines for the management of inflammatory bowel disease in adults. Gut. 2004;53(SUPPL. 5):v1-v16. & Non-orthodontic subject \\
\hline 235 & Cassidy JT. Medical management of children with juvenile rheumatoid arthritis. Drugs. 1999;58(5):831-50. & Non-orthodontic subject \\
\hline 236 & $\begin{array}{l}\text { Cates C. Benzodiazepine use in pregnancy and major malformations or oral clefts. Pooled results are sensitive to zero transformation used. BMJ (Clinical } \\
\text { research ed). } 1999 ; 319(7214): 918-9 \text {. }\end{array}$ & Non-orthodontic subject \\
\hline 237 & $\begin{array}{l}\text { Chaimani A, Vasiliadis HS, Pandis N, Schmid CH, Welton NJ, Salanti G. Effects of study precision and risk of bias in networks of interventions: a network } \\
\text { meta-epidemiological study. International journal of epidemiology. 2013;42(4):1120-31. }\end{array}$ & Non-orthodontic subject \\
\hline 238 & Chambers C. Safety of asthma and allergy medications in pregnancy. Immunology and Allergy Clinics of North America. 2006;26(1):13-28. & Non-orthodontic subject \\
\hline 239 & $\begin{array}{l}\text { Chambers CD, Tutuncu ZN, Johnson D, Jones KL. Human pregnancy safety for agents used to treat rheumatoid arthritis: Adequacy of available } \\
\text { information and strategies for developing post-marketing data. Arthritis Research and Therapy. 2006;8(4). }\end{array}$ & Non-orthodontic subject \\
\hline 240 & $\begin{array}{l}\text { Chambrone L, Sukekava F, Araújo MG, Pustiglioni FE, Chambrone LA, Lima LA. Root coverage procedures for the treatment of localised recession-type } \\
\text { defects. Cochrane Database of Systematic Reviews. 2009(2). }\end{array}$ & Non-orthodontic subject \\
\hline 241 & Chapple ILC, Hamburger J. The significance of oral health in HIV disease. Sexually Transmitted Infections. 2000;76(4):236-43. & Non-orthodontic subject \\
\hline 242 & $\begin{array}{l}\text { Chatzopoulos GS, Doufexi AE, Kalogirou F. Association of susceptible genotypes to periodontal disease with the clinical outcome and tooth survival after } \\
\text { non-surgical periodontal therapy: A systematic review and meta-analysis. Medicina oral, patologia oral y cirugia bucal. 2016;21(1):e14-e29. }\end{array}$ & Non-orthodontic subject \\
\hline 243 & $\begin{array}{l}\text { Chen F, Zhao H, Zhang J, Zhang M, Deng F, Zheng L, et al. Is MTHFD1 polymorphism rs } 2236225 \text { (c.1958G>A) associated with the susceptibility of } \\
\text { NSCL/P? A systematic review and meta-analysis. F1000Research. 2016;4:1-19. }\end{array}$ & Non-orthodontic subject \\
\hline 244 & $\begin{array}{l}\text { Chen Y, Wong RW, McGrath C, Hagg U, Seneviratne CJ. Natural compounds containing mouthrinses in the management of dental plaque and gingivitis: } \\
\text { a systematic review. Clinical oral investigations. 2014;18(1):1-16. }\end{array}$ & Non-orthodontic subject \\
\hline 245 & $\begin{array}{l}\text { Chen YJ, Han Y, Mao M, Tan YQ, Leng WD, Zeng XT. Interleukin-1 } 1 \beta \text { rs1143634 polymorphism andaggressive periodontitis susceptibility: A meta- } \\
\text { analysis. International journal of clinical and experimental medicine. 2015;8(2):2308-16. }\end{array}$ & Non-orthodontic subject \\
\hline 246 & $\begin{array}{l}\text { Cheng X, Niu Y, Ding Q, Yin X, Huang G, Peng J, et al. Cadmium Exposure and Risk of Any Fracture: A PRISMA-Compliant Systematic Review and } \\
\text { Meta-Analysis. Medicine. 2016;95(10):e2932. }\end{array}$ & Non-orthodontic subject \\
\hline 247 & $\begin{array}{l}\text { Cheng Y, Chen JW, Ge MK, Zhou ZY, Yin X, Zou SJ. Efficacy of adjunctive laser in non-surgical periodontal treatment: a systematic review and meta- } \\
\text { analysis. Lasers in medical science. 2016;31(1):151-63. }\end{array}$ & Non-orthodontic subject \\
\hline 248 & $\begin{array}{l}\text { Cheung CL, Sham PC, Xiao SM, Bow CH, Kung AWC. Meta-analysis of gene-based genome-wide association studies of bone mineral density in Chinese } \\
\text { and European subjects. Osteoporosis International. 2012;23(1):131-42. }\end{array}$ & Non-orthodontic subject \\
\hline 249 & $\begin{array}{l}\text { Cheung LK, Chua HD. A meta-analysis of cleft maxillary osteotomy and distraction osteogenesis. International journal of oral and maxillofacial surgery. } \\
\text { 2006;35(1):14-24. }\end{array}$ & Non-orthodontic subject \\
\hline 250 & Chi CC, Lee CW, Wojnarowska F, Kirtschig G. Safety of topical corticosteroids in pregnancy. Cochrane Database Syst Rev 2009(3):Cd007346. & Non-orthodontic subject \\
\hline 251 & $\begin{array}{l}\text { Chi CC, Wang SH, Wojnarowska F, Kirtschig G, Davies E, Bennett C. Safety of topical corticosteroids in pregnancy. Cochrane Database Syst Rev } \\
2015(10) \text { :Cd007346. }\end{array}$ & Non-orthodontic subject \\
\hline 252 & Cholera M, Chainani-Wu N. Management of Pemphigus Vulgaris. Advances in Therapy. 2016;33(6):910-58. & Non-orthodontic subject \\
\hline 253 & $\begin{array}{l}\text { Chrcanovic BR. Locking versus non-locking plate fixation in the management of mandibular fractures: a meta-analysis. International journal of oral and } \\
\text { maxillofacial surgery. } 2014 ; 43(10): 1243-50 \text {. }\end{array}$ & Non-orthodontic subject \\
\hline 254 & $\begin{array}{l}\text { Chrcanovic BR. Surgical versus non-surgical treatment of mandibular condylar fractures: a meta-analysis. International journal of oral and maxillofacial } \\
\text { surgery. 2015;44(2):158-79. }\end{array}$ & Non-orthodontic subject \\
\hline 255 & $\begin{array}{l}\text { Chrzeszczyk D, Konopka T, Zieetek M. Polymorphisms of toll-like receptor } 4 \text { as a risk factor for periodontitis: Meta-analysis. Advances in Clinical and } \\
\text { Experimental Medicine. 2015;24(6):1059-70. }\end{array}$ & Non-orthodontic subject \\
\hline 256 & $\begin{array}{l}\text { Chun JS, Har A, Lim HP, Lim HJ. The analysis of cost-effectiveness of implant and conventional fixed dental prosthesis. The journal of advanced } \\
\text { prosthodontics. } 2016 ; 8(1): 53-61 \text {. }\end{array}$ & Non-orthodontic subject \\
\hline 257 & $\begin{array}{l}\text { Clauser C, Nieri M, Franceschi D, Pagliaro U, Pini-Prato G. Evidence-based mucogingival therapy. Part 2: Ordinary and individual patient data meta- } \\
\text { analyses of surgical treatment of recession using complete root coverage as the outcome variable. Journal of periodontology. 2003;74(5):741-56. }\end{array}$ & Non-orthodontic subject \\
\hline 258 & $\begin{array}{l}\text { Coelho FJMJ, Birks J. Physostigmine for dementia due to Alzheimer's disease. Cochrane Database of Systematic Reviews. 2001; (2). Available from: } \\
\text { http://onlinelibrary.wiley.com/doi/10.1002/14651858.CD001499/abstract }\end{array}$ & Non-orthodontic subject \\
\hline 259 & Coletta RD, Graner E. Hereditary gingival fibromatosis: A systematic review. Journal of periodontology. 2006;77(5):753-64. & Non-orthodontic subject \\
\hline 260 & $\begin{array}{l}\text { Collins J, Cheung K, Farrokhyar F, Strumas N. Pharyngeal flap versus sphincter pharyngoplasty for the treatment of velopharyngeal insufficiency: a meta- } \\
\text { analysis. Journal of plastic, reconstructive \& aesthetic surgery : JPRAS. 2012;65(7):864-8. }\end{array}$ & Non-orthodontic subject \\
\hline 261 & $\begin{array}{l}\text { Colquitt JL, Kirby J, Green C, Cooper K, Trompeter RS. The clinical effectiveness and cost-effectiveness of treatments for children with idiopathic steroid- } \\
\text { resistant nephrotic syndrome: A systematic review. Health Technology Assessment. 2007;11(21):iii-49. }\end{array}$ & Non-orthodontic subject \\
\hline 262 & Conde-Agudelo A, Romero R. Maternal periodontal disease and risk of preeclampsia: A systematic review & Non-orthodontic subject \\
\hline
\end{tabular}




\begin{tabular}{|c|c|c|}
\hline & Obstetrics and Gynecology. 2009;201(6):S285. & \\
\hline 263 & $\begin{array}{l}\text { Conde-Agudelo A, Villar J, Lindheimer M. Maternal infection and risk of preeclampsia: Systematic review and metaanalysis. American Journal of } \\
\text { Obstetrics and Gynecology. 2008;198(1):7-22. }\end{array}$ & Non-orthodontic subject \\
\hline 264 & $\begin{array}{l}\text { Connock M, Frew E, Evans BW, Bryan S, Cummins C, Fry-Smith A, et al. The clinical effectiveness and cost-effectiveness of newer drugs for children with } \\
\text { epilepsy. A systematic review. Health Technology Assessment. 2006;10(7):iii-118. }\end{array}$ & Non-orthodontic subject \\
\hline 265 & $\begin{array}{l}\text { Corbella S, Del Fabbro M, Taschieri S, Francetti L. Periodontal disease and adverse pregnancy outcomes: A systematic review. Italian Oral Surgery. } \\
\text { 2012;11(4):132-46. }\end{array}$ & Non-orthodontic subject \\
\hline 266 & Correa A, Marcinkevage J. Prepregnancy obesity and the risk of birth defects: An update. Nutrition Reviews. 2013;71(SUPPL1):S68-S77. & Non-orthodontic subject \\
\hline 267 & $\begin{array}{l}\text { Correa-Faria P, Martins CC, Bonecker M, Paiva SM, Ramos-Jorge ML, Pordeus IA. Absence of an association between socioeconomic indicators and } \\
\text { traumatic dental injury: a systematic review and meta-analysis. Dent Traumatol 2015;31(4):255-66. }\end{array}$ & Non-orthodontic subject \\
\hline 268 & $\begin{array}{l}\text { Correa-Faria P, Martins CC, Bonecker M, Paiva SM, Ramos-Jorge ML, Pordeus IA. Clinical factors and socio-demographic characteristics associated with } \\
\text { dental trauma in children: a systematic review and meta-analysis. Dent Traumatol 2016;32(5):367-78. }\end{array}$ & Non-orthodontic subject \\
\hline 269 & $\begin{array}{l}\text { Correa-Faria P, Petti S. Are overweight/obese children at risk of traumatic dental injuries? A meta-analysis of observational studies. Dent Traumatol } \\
\text { 2015;31(4):274-82. }\end{array}$ & Non-orthodontic subject \\
\hline 270 & $\begin{array}{l}\text { Cosgrove RH, Zacharski LR, Racine E, Andersen JC. Improved cancer mortality with low-molecular-weight heparin treatment A review of the evidence. } \\
\text { Seminars in Thrombosis and Hemostasis. 2002;28(1):79-87. }\end{array}$ & Non-orthodontic subject \\
\hline 271 & $\begin{array}{l}\text { Costa LA, Ribeiro CC, Cantanhede LM, Santiago Junior JF, de Mendonca MR, Pereira AL. Treatments for intrusive luxation in permanent teeth: a } \\
\text { systematic review and meta-analysis. International journal of oral and maxillofacial surgery. } 2016 \text {. }\end{array}$ & Non-orthodontic subject \\
\hline 272 & $\begin{array}{l}\text { Cui G, Xu X, Diao H. Comparative Meta-Analysis of Tenofovir Disoproxil Fumarate versus Emtricitabine and Tenofovir Disoproxil Fumarate as Treatments } \\
\text { for Patients with Chronic Hepatitis B. Scientific reports. 2015;5:11854. }\end{array}$ & Non-orthodontic subject \\
\hline 273 & Czeizel AE. Is folic acid a risk factor for oral clefts? European Journal of Epidemiology. 2013;28(11):841-3. & Non-orthodontic subject \\
\hline 274 & $\begin{array}{l}\text { da Silva Bastos Vde A, Freitas-Fernandes LB, Fidalgo TK, Martins C, Mattos CT, de Souza IP, et al. Mother-to-child transmission of Streptococcus } \\
\text { mutans: a systematic review and meta-analysis. Journal of dentistry. 2015;43(2):181-91. }\end{array}$ & Non-orthodontic subject \\
\hline 275 & $\begin{array}{l}\text { da Silva CG, Pacheco-Pereira C, Porporatti AL, Savi MG, Peres MA, Flores-Mir C, et al. Prevalence of clinical signs of intra-articular temporomandibular } \\
\text { disorders in children and adolescents. Journal of the American Dental Association. 2016;147(1):10-+. }\end{array}$ & Non-orthodontic subject \\
\hline 276 & $\begin{array}{l}\text { da Veiga AM, Cunha AC, Ferreira DM, da Silva Fidalgo TK, Chianca TK, Reis KR, et al. Longevity of direct and indirect resin composite restorations in } \\
\text { permanent posterior teeth: A systematic review and meta-analysis. Journal of dentistry. 2016;54:1-12. }\end{array}$ & Non-orthodontic subject \\
\hline 277 & D'Andrea G. Pycnogenol: A blend of procyanidins with multifaceted therapeutic applications? Fitoterapia. 2010;81(7):724-36. & Non-orthodontic subject \\
\hline 278 & $\begin{array}{l}\text { Darré L, Vergnes JN, Gourdy P, Sixou M. Efficacy of periodontal treatment on glycaemic control in diabetic patients: A meta-analysis of interventional } \\
\text { studies. Diabetes and Metabolism. 2008;34(5):497-506. }\end{array}$ & Non-orthodontic subject \\
\hline 279 & $\begin{array}{l}\text { de Silva AM, Hegde S, Akudo Nwagbara B, Calache H, Gussy MG, Nasser M, et al. Community-based population-level interventions for promoting child } \\
\text { oral health. Cochrane Database of Systematic Reviews. 2016;2016(9). }\end{array}$ & Non-orthodontic subject \\
\hline 280 & $\begin{array}{l}\text { Deacon SA, Glenny AM, Deery C, Robinson PG, Heanue M, Walmsley AD, et al. Different powered toothbrushes for plaque control and gingival health. } \\
\text { Cochrane Database Syst Rev 2010(12):Cd004971. }\end{array}$ & Non-orthodontic subject \\
\hline 281 & $\begin{array}{l}\text { Deguen S, Kinal W, Jeanjean M, Padilla C, Zmirou-Navier D. Neighborhood Deprivation and Risk of Congenital Heart Defects, Neural Tube Defects and } \\
\text { Orofacial Clefts: A Systematic Review and Meta-Analysis. PloS one. 2016;11(10):e0159039. }\end{array}$ & Non-orthodontic subject \\
\hline 282 & $\begin{array}{l}\text { Del Corso M, Vervelle A, Simonpieri A, Jimbo R, Inchingolo F, Sammartino G, et al. Current knowledge and perspectives for the use of Platelet-Rich } \\
\text { Plasma (PRP) and Platelet-Rich Fibrin (PRF) in oral and maxillofacial surgery part 1: Periodontal and dentoalveolar surgery. Current Pharmaceutical } \\
\text { Biotechnology. 2012;13(7):1207-30. }\end{array}$ & Non-orthodontic subject \\
\hline 283 & $\begin{array}{l}\text { Dell'osso B, Lader M. Do benzodiazepines still deserve a major role in the treatment of psychiatric disorders? A critical reappraisal. European Psychiatry. } \\
2013 ; 28(1): 7-20 \text {. }\end{array}$ & Non-orthodontic subject \\
\hline 284 & $\begin{array}{l}\text { Demmer RT, Trinquart L, Zuk A, Fu BC, Blomkvist J, Michalowicz BS, et al. The Influence of Anti-Infective Periodontal Treatment on C-Reactive Protein: A } \\
\text { Systematic Review and Meta-Analysis of Randomized Controlled Trials. PloS one. } 2013 ; 8(10) \text {. }\end{array}$ & Non-orthodontic subject \\
\hline 285 & $\begin{array}{l}\text { Deng JS, Qin P, Li XX, Du YH. Association between interleukin-1 } 3 \text { C (3953/4)T polymorphism and chronic periodontitis: Evidence from a meta-analysis. } \\
\text { Human immunology. 2013;74(3):371-8. }\end{array}$ & Non-orthodontic subject \\
\hline 286 & $\begin{array}{l}\text { Deps TD, Angelo GL, Martins CC, Paiva SM, Pordeus IA, Borges-Oliveira AC. Association between Dental Caries and Down Syndrome: A Systematic } \\
\text { Review and Meta-Analysis. PloS one. 2015;10(6):e0127484. }\end{array}$ & Non-orthodontic subject \\
\hline 287 & $\begin{array}{l}\text { De-Regil LM, Fernandez-Gaxiola AC, Dowswell T, Pena-Rosas JP. Effects and safety of periconceptional folate supplementation for preventing birth } \\
\text { defects. Cochrane Database Syst Rev 2010(10):Cd007950. }\end{array}$ & Non-orthodontic subject \\
\hline 288 & $\begin{array}{l}\text { De-Regil LM, Pena-Rosas JP, Fernandez-Gaxiola AC, Rayco-Solon P. Effects and safety of periconceptional oral folate supplementation for preventing } \\
\text { birth defects. Cochrane Database Syst Rev 2015(12):Cd007950. }\end{array}$ & Non-orthodontic subject \\
\hline 289 & $\begin{array}{l}\text { Derks LSM, Veenstra HJ, Oomen KPQ, Speleman L, Stegeman I. Surgery Versus Endoscopic Cauterization in Patients With Third or Fourth Branchial } \\
\text { Pouch Sinuses: A Systematic Review. Laryngoscope. 2016;126(1):212-7. }\end{array}$ & Non-orthodontic subject \\
\hline 290 & $\begin{array}{l}\text { Dewinter G, Teunkens A, Altmi L, Van De Velde M, Rex S. Refresher course: The role of intravenous lidocaine in modern anesthesia. Regional } \\
\text { Anesthesia and Pain Medicine. 2015;40(5):e1-e4. }\end{array}$ & Non-orthodontic subject \\
\hline 291 & Dickerson LM, Gibson MV. Management of hypertension in older persons. American Family Physician. 2005;71(3):469-76. & Non-orthodontic subject \\
\hline 292 & $\begin{array}{l}\text { Dietrich T, Garcia Rl. Associations between periodontal disease and systemic disease: Evaluating the strength of the evidence. Journal of periodontology. } \\
2005 ; 76(11 \text { SUPPL.):2175-84. }\end{array}$ & Non-orthodontic subject \\
\hline 293 & $\begin{array}{l}\text { Dogramaci EJ, Rossi-Fedele G. Establishing the association between nonnutritive sucking behavior and malocclusions: A systematic review and meta- } \\
\text { analysis. Journal of the American Dental Association (1939). 2016;147(12):926-34.e6. }\end{array}$ & Non-orthodontic subject \\
\hline 294 & $\begin{array}{l}\text { Dolovich LR, Addis A, Vaillancourt JM, Power JD, Koren G, Einarson TR. Benzodiazepine use in pregnancy and major malformations or oral cleft: meta- } \\
\text { analysis of cohort and case-control studies. BMJ (Clinical research ed). 1998;317(7162):839-43. }\end{array}$ & Non-orthodontic subject \\
\hline 295 & $\begin{array}{l}\text { Dols A, Sienaert P, Van Gerven H, Schouws S, Stevens A, Kupka R, et al. The prevalence and management of side effects of lithium and anticonvulsants } \\
\text { as mood stabilizers in bipolar disorder from a clinical perspective: A review. International Clinical Psychopharmacology. 2013;28(6):287-96. }\end{array}$ & Non-orthodontic subject \\
\hline 296 & $\begin{array}{l}\text { Dong L, Ma L. GFA Taq I polymorphism and cleft lip with or without cleft palate (CL/P) risk. International journal of clinical and experimental medicine. } \\
2015 ; 8(3): 3545-51 \text {. }\end{array}$ & Non-orthodontic subject \\
\hline 297 & Dooley M, Goa KL. Sibrafiban. Drugs. 1999;57(2):225-30. & Non-orthodontic subject \\
\hline 298 & Dore MP, Graham DY. Ulcers and gastritis. Endoscopy. 2004;36(1):42-7. & Non-orthodontic subject \\
\hline 299 & Dötsch J, Rascher W, Plank C. Treatment of idiopathic nephrotic syndrome of childhood. Monatsschrift fur Kinderheilkunde. 2004;152(3):265-72. & Non-orthodontic subject \\
\hline 300 & $\begin{array}{l}\text { Dreier JW, Andersen AM, Berg-Beckhoff G. Systematic review and meta-analyses: fever in pregnancy and health impacts in the offspring. Pediatrics. } \\
\text { 2014;133(3):e674-88. }\end{array}$ & Non-orthodontic subject \\
\hline 301 & $\begin{array}{l}\text { Dunkhase E, Ludwig KU, Böhmer AC, Knapp M, Nöthen MM, Mattheisen M, et al. Nonsyndromic orofacial clefting and cancer-evaluating a possible } \\
\text { common genetic background by analyzing GWAS data. Medizinische Genetik. 2014;26(1):161. }\end{array}$ & Non-orthodontic subject \\
\hline 302 & Eberhard-Gran M, Eskild A, Opjordsmoen S. Treating mood disorders during pregnancy: Safety considerations. Drug Safety. 2005;28(8):695-706. & Non-orthodontic subject \\
\hline 303 & $\begin{array}{l}\text { Eck JC, Nachtigall D, Humphreys SC, Hodges SD. Comparison of vertebroplasty and balloon kyphoplasty for treatment of vertebral compression } \\
\text { fractures: a meta-analysis of the literature. Spine Journal. } 2008 ; 8(3): 488-97 \text {. }\end{array}$ & Non-orthodontic subject \\
\hline 304 & Eikelboom JW, Hankey GJ. Low molecular weight heparins and heparinoids. Medical Journal of Australia. 2002;177(7):379-83. & Non-orthodontic subject \\
\hline 305 & Ekberg H. Tailoring of minimal immunosuppression long term. Transplantation Proceedings. 2003;35(2):755-7. & Non-orthodontic subject \\
\hline 306 & $\begin{array}{l}\text { Ekenze SO, Ajuzieogu OV, Nwomeh BC. Neonatal surgery in Africa: a systematic review and meta-analysis of challenges of management and outcome. } \\
\text { Lancet (London, England). 2015;385 Suppl 2:S35. }\end{array}$ & Non-orthodontic subject \\
\hline 307 & $\begin{array}{l}\text { Enato E, Moretti M, Koren G. The fetal safety of benzodiazepines: an updated meta-analysis. Journal of obstetrics and gynaecology Canada : JOGC = } \\
\text { Journal d'obstetrique et gynecologie du Canada : JOGC. 2011;33(1):46-8. }\end{array}$ & Non-orthodontic subject \\
\hline 308 & $\begin{array}{l}\text { Esposito M, Grusovin MG, Kwan S, Worthington HV, Coulthard P. Interventions for replacing missing teeth: Bone augmentation techniques for dental } \\
\text { implant treatment. Cochrane Database of Systematic Reviews. 2008(3). }\end{array}$ & Non-orthodontic subject \\
\hline 309 & $\begin{array}{l}\text { Esposito M, Grusovin MG, Talati M, Coulthard P, Oliver R, Worthington HV. Interventions for replacing missing teeth: Antibiotics at dental implant } \\
\text { placement to prevent complications. Cochrane Database of Systematic Reviews. 2008(3). }\end{array}$ & Non-orthodontic subject \\
\hline 310 & $\begin{array}{l}\text { Esposito M, Hirsch JM, Lekholm U, Thomsen P. Biological factors contributing to failures of osseointegrated oral implants. (II). Etiopathogenesis. } \\
\text { European journal of oral sciences. 1998;106(3):721-64. }\end{array}$ & Non-orthodontic subject \\
\hline 311 & $\begin{array}{l}\text { Esteves Lima RP, Cyrino RM, de Carvalho Dutra B, Oliveira da Silveira J, Martins CC, Miranda Cota LO, et al. Association Between Periodontitis and } \\
\text { Gestational Diabetes Mellitus: Systematic Review and Meta-Analysis. Journal of periodontology. 2016;87(1):48-57. }\end{array}$ & Non-orthodontic subject \\
\hline 312 & $\begin{array}{l}\text { Fan L, Kuang Q, Tang Y, Qin P. [Effect of premolar extractions on third molar angulation changes: a meta-analysis]. Zhong nan da xue xue bao Yi xue } \\
\text { ban = Journal of Central South University Medical sciences. 2015;40(3):317-25. }\end{array}$ & Non-orthodontic subject \\
\hline
\end{tabular}




\begin{tabular}{|c|c|c|}
\hline 313 & $\begin{array}{l}\text { Fatemifar G, Hoggart CJ, Paternoster L, Kemp JP, Prokopenko I, Horikoshi M, et al. Genome-wide association study of primary tooth eruption identifies } \\
\text { pleiotropic loci associated with height and craniofacial distances. Human molecular genetics. } 2013 ; 22(18): 3807-17 \text {. }\end{array}$ & Non-orthodontic subject \\
\hline 314 & $\begin{array}{l}\text { Fatunde A. Did hurricane affect the prevalence of oral clefts among children aged 0-3 years born in the state of Louisiana 2005-2008? Cleft Palate- } \\
\text { Craniofacial Journal. } 2016 ; 53(4): e 150 .\end{array}$ & Non-orthodontic subject \\
\hline 315 & $\begin{array}{l}\text { Fekete K, Berti C, Trovato M, Lohner S, Dullemeijer C, Souverein OW, et al. Effect of folate intake on health outcomes in pregnancy: a systematic review } \\
\text { and meta-analysis on birth weight, placental weight and length of gestation. Nutrition Journal. 2012;11. }\end{array}$ & Non-orthodontic subject \\
\hline 316 & $\begin{array}{l}\text { Feng C, Zhang E, Duan W, Xu Z, Zhang Y, Lu L. Association between polymorphism of TGFA Taq I and cleft lip and/or palate: a meta-analysis. BMC oral } \\
\text { health. } 2014 ; 14: 88 \text {. }\end{array}$ & Non-orthodontic subject \\
\hline 317 & $\begin{array}{l}\text { Feng C, Zhang E, Xu ZF, Duan WY, Tan XX, Sun CF. Association between polymorphisms in MDM2 gene and oral cancer risk: A meta-analysis. } \\
\text { International journal of clinical and experimental medicine. } 2016 ; 9(8): 15457-66 \text {. }\end{array}$ & Non-orthodontic subject \\
\hline 318 & $\begin{array}{l}\text { Feriani G, Hatanaka E, Torloni MR, da Silva EM. Infraorbital nerve block for postoperative pain following cleft lip repair in children. Cochrane Database } \\
\text { Syst Rev 2016;4:Cd011131. }\end{array}$ & Non-orthodontic subject \\
\hline 319 & Fernández O, Fernández V, De Ramón E. Azathioprine and methotrexate in multiple sclerosis. Journal of the Neurological Sciences. 2004;223(1):29-34. & Non-orthodontic subject \\
\hline 320 & $\begin{array}{l}\text { Fidalgo TK, Freitas-Fernandes LB, Ammari M, Mattos CT, de Souza IP, Maia LC. The relationship between unspecific s-IgA and dental caries: a } \\
\text { systematic review and meta-analysis. Journal of dentistry. 2014;42(11):1372-81. }\end{array}$ & Non-orthodontic subject \\
\hline 321 & $\begin{array}{l}\text { Figueiredo JC, Ly S, Raimondi H, Magee K, Baurley JW, Sanchez-Lara PA, et al. Genetic risk factors for orofacial clefts in Central Africans and Southeast } \\
\text { Asians. American journal of medical genetics Part A. } 2014 ; 164 \mathrm{a}(10): 2572-80 \text {. }\end{array}$ & Non-orthodontic subject \\
\hline 322 & $\begin{array}{l}\text { Filius MA, Cune MS, Raghoebar GM, Vissink A, Visser A. Prosthetic treatment outcome in patients with severe hypodontia: a systematic review. Journal } \\
\text { of oral rehabilitation. } 2016 ; 43(5): 373-87 \text {. }\end{array}$ & Non-orthodontic subject \\
\hline 323 & Filler G. Calcineurin inhibitors in pediatric renal transplant recipients. Pediatric Drugs. 2007;9(3):165-74. & Non-orthodontic subject \\
\hline 324 & $\begin{array}{l}\text { Flack JM, Hamaty M. Difficult-to-treat hypertensive populations: Focus on African-Americans and people with type } 2 \text { diabetes. Journal of Hypertension, } \\
\text { Supplement. 1999;17(1):S19-S24. }\end{array}$ & Non-orthodontic subject \\
\hline 325 & $\begin{array}{l}\text { Flores-Mir C, Korayem M, Heo G, Witmans M, Major MP, Major PW. Craniofacial morphological characteristics in children with obstructive sleep apnea } \\
\text { syndrome: a systematic review and meta-analysis. Journal of the American Dental Association (1939). 2013;144(3):269-77. }\end{array}$ & Non-orthodontic subject \\
\hline 326 & $\begin{array}{l}\text { Freeman EE, Easterbrook P, Muhe L, Hay R, Martin J, Maurer T. The role of evidence based dermatology in World Health Organization guidelines. } \\
\text { Journal of Investigative Dermatology. 2013;133:S96. }\end{array}$ & Non-orthodontic subject \\
\hline 327 & $\begin{array}{l}\text { Friedewald VE, Kornman KS, Offenbacher S, Beck J, Taylor GW, Borgnakke WS. Periodontitis and Cardiovascular Disease. American Journal of } \\
\text { Cardiology. 2010;105(3):425-8. }\end{array}$ & Non-orthodontic subject \\
\hline 328 & $\begin{array}{l}\text { Fuggle NR, Smith TO, Kaul A, Sofat N. Dental association or incidental finding? A meta-analysis and systematic review of the relationship between } \\
\text { rheumatoid arthritis and periodontitis. Annals of the Rheumatic Diseases. 2016;75:468. }\end{array}$ & Non-orthodontic subject \\
\hline 329 & $\begin{array}{l}\text { Fuggle NR, Smith TO, Kaul A, Sofat N. Hand to mouth: A systematic review and meta-analysis of the association between rheumatoid arthritis and } \\
\text { periodontitis. Frontiers in Immunology. 2016;7(MAR). }\end{array}$ & Non-orthodontic subject \\
\hline 330 & $\begin{array}{l}\text { Furber CM, McGowan L, Bower P, Kontopantelis E, Quenby S, Lavender T. Antenatal interventions for reducing weight in obese wo men for improving } \\
\text { pregnancy outcome. Cochrane Database of Systematic Reviews. 2013; (1). Available from: } \\
\text { http://onlinelibrary.wiley.com/doi/10.1002/14651858.CD009334.pub2/abstract }\end{array}$ & Non-orthodontic subject \\
\hline 331 & $\begin{array}{l}\text { Gao YF, Guo LW, Zhou J, Li SM. Platelet-rich plasma for the treatment of periodontal intrabony defects: A meta-analysis. Chinese Journal of Evidence- } \\
\text { Based Medicine. } 2013 ; 13(6): 741-6 \text {. }\end{array}$ & Non-orthodontic subject \\
\hline 332 & Gapski R, Parks CA, Wang HL. A cellular dermal matrix for mucogingival surgery: A meta-analysis. Journal of periodontology. 2005;76(11):1814-22. & Non-orthodontic subject \\
\hline 333 & $\begin{array}{l}\text { Garg P, Chaman C. Apical periodontitis - Is it accountable for cardiovascular diseases? Journal of Clinical and Diagnostic Research. 2016;10(8):ZE08- } \\
\text { ZE12. }\end{array}$ & Non-orthodontic subject \\
\hline 334 & $\begin{array}{l}\text { Garg P, Ludwig KU, Bohmer AC, Rubini M, Steegers-Theunissen R, Mossey PA, et al. Genome-wide analysis of parent-of-origin effects in non-syndromic } \\
\text { orofacial clefts. European journal of human genetics : EJHG. 2014;22(6):822-30. }\end{array}$ & Non-orthodontic subject \\
\hline 335 & $\begin{array}{l}\text { Genovesi AM, Sanavia C, Marchisio O, Lorenzi C, Giacomelli L, Bisacchi F, et al. Oral hygiene protocols: a literature review. Prevenzione e Assistenza } \\
\text { Dentale. 2010;36(1):17-23. }\end{array}$ & Non-orthodontic subject \\
\hline 336 & $\begin{array}{l}\text { Gerritsen AE, Allen PF, Witter DJ, Bronkhorst EM, Creugers NHJ. Tooth loss and oral health-related quality of life: A systematic review and meta-analysis. } \\
\text { Health and Quality of Life Outcomes. 2010;8. }\end{array}$ & Non-orthodontic subject \\
\hline 337 & $\begin{array}{l}\text { Ghaeminia H, Perry J, Nienhuijs ME, Toedtling V, Tummers M, Hoppenreijs TJ, et al. Surgical removal versus retention for the management of } \\
\text { asymptomatic disease-free impacted wisdom teeth. Cochrane Database of Systematic Reviews. 2016; (8). }\end{array}$ & Non-orthodontic subject \\
\hline 338 & $\begin{array}{l}\text { Ghanem A, Pasumarthy S, Ranna V, Kellesarian SV, Abduljabbar T, Vohra F, et al. Is mechanical curettage with adjunct photodynamic therapy more } \\
\text { effective in the treatment of peri-implantitis than mechanical curettage alone? Photodiagnosis and Photodynamic Therapy. 2016;15:191-6. }\end{array}$ & Non-orthodontic subject \\
\hline 339 & $\begin{array}{l}\text { Gilboa SM, Broussard CS, Devine OJ, Duwe KN, Flak AL, Boulet SL, et al. Influencing clinical practice regarding the use of antiepileptic medications } \\
\text { during pregnancy: Modeling the potential impact on the prevalences of spina bifida and cleft palate in the United States. American Journal of Medical } \\
\text { Genetics, Part C: Seminars in Medical Genetics. } 2011 ; 157(3): 234-46 \text {. }\end{array}$ & Non-orthodontic subject \\
\hline 340 & $\begin{array}{l}\text { Gilleard O, Sell D, Ghanem A, Tavsanoglu Y, Birch M, Sommerlad B. Submucous cleft palate: a systematic review of surgical management based on } \\
\text { perceptual and instrumental analysis. Database of Abstracts of Reviews of Effects. 2014; (2):[686-95 pp.]. }\end{array}$ & Non-orthodontic subject \\
\hline 341 & $\begin{array}{l}\text { Gillies M, Ranakusuma A, Hoffmann T, Thorning S, McGuire T, Glasziou P, et al. Common harms from amoxicillin: A systematic review and meta-analysis } \\
\text { of randomized placebo-controlled trials for any indication. CMAJ. 2015;187(1):E21-E31. }\end{array}$ & Non-orthodontic subject \\
\hline 342 & $\begin{array}{l}\text { Gionchetti P, Rizzello F, Habal F, Morselli C, Amadini C, Romagnoli R, et al. Standard treatment of ulcerative colitis. Digestive Diseases. 2003;21(2):157- } \\
67 .\end{array}$ & Non-orthodontic subject \\
\hline 343 & $\begin{array}{l}\text { Glass GE, Waterhouse N, Shakib K. Hilotherapy for the management of perioperative pain and swelling in facial surgery: a systematic review and meta- } \\
\text { analysis. The British journal of oral \& maxillofacial surgery. } 2016 ; 54(8): 851-6 \text {. }\end{array}$ & Non-orthodontic subject \\
\hline 344 & $\begin{array}{l}\text { Goh YI, Bollano E, Einarson TR, Koren G. Prenatal multivitamin supplementation and rates of congenital anomalies: a meta-analysis. Journal of obstetrics } \\
\text { and gynaecology Canada : JOGC = Journal d'obstetrique et gynecologie du Canada : JOGC. 2006;28(8):680-9. }\end{array}$ & Non-orthodontic subject \\
\hline 345 & $\begin{array}{l}\text { Golan I, Baumert U, Hrala BP, Mussig D. Dentomaxillofacial variability of cleidocranial dysplasia: clinicoradiological presentation and systematic review. } \\
\text { Dento maxillo facial radiology. } 2003 ; 32(6): 347-54 \text {. }\end{array}$ & Non-orthodontic subject \\
\hline 346 & $\begin{array}{l}\text { Goldberg O, Moretti M, Levy A, Koren G. Exposure to nitrofurantoin during early pregnancy and congenital malformations: a systematic review and meta- } \\
\text { analysis. Journal of obstetrics and gynaecology Canada : JOGC = Journal d'obstetrique et gynecologie du Canada : JOGC. 2015;37(2):150-6. }\end{array}$ & Non-orthodontic subject \\
\hline 347 & $\begin{array}{l}\text { Goldstein LB, Adams R, Alberts MJ, Appel LJ, Brass LM, Bushnell CD, et al. Primary prevention of ischemic stroke. A guideline from the American Heart } \\
\text { Association/American Stroke Association Stroke Council: Cosponsored by the Atherosclerotic Peripheral Vascular Disease Interdisciplinary Working } \\
\text { Group; Cardiovascular Nursing Council; Clinical Cardiology Council; Nutrition, Physical Activity, and Metabolism Council. Stroke. 2006;37(6):1583-633. }\end{array}$ & Non-orthodontic subject \\
\hline 348 & $\begin{array}{l}\text { Gowans LJJ, Adeyemo WL, Eshete M, Mossey PA, Busch T, Aregbesola B, et al. Association studies and direct DNA sequencing implicate genetic } \\
\text { susceptibility loci in the etiology of nonsyndromic orofacial clefts in sub-Saharan African populations. Journal of dental research. 2016;95(11):1245-56. }\end{array}$ & Non-orthodontic subject \\
\hline 349 & Graff-Radford SB. Migraine prophylaxis. Clinics in Family Practice. 2005;7(3 SPEC. ISS.):445-62. & Non-orthodontic subject \\
\hline 350 & $\begin{array}{l}\text { Greenstein G. Local drug delivery in the treatment of periodontal diseases: Assessing the clinical significance of the results. Journal of periodontology. } \\
2006 ; 77(4): 565-78 \text {. }\end{array}$ & Non-orthodontic subject \\
\hline 351 & $\begin{array}{l}\text { Grooten IJ, Vinke ME, Roseboom TJ, Painter RC. A Systematic Review and Meta-Analysis of the Utility of Corticosteroids in the Treatment of } \\
\text { Hyperemesis Gravidarum. Nutrition and Metabolic Insights. 2015;8:23-32. }\end{array}$ & Non-orthodontic subject \\
\hline 352 & $\begin{array}{l}\text { Grossberg GT. Effect of rivastigmine in the treatment of behavioral disturbances associated with dementia: review of neuropsychiatric impairment in } \\
\text { Alzheimer's disease. Current medical research and opinion. } 2005 ; 21(10): 1631-9 \text {. }\end{array}$ & Non-orthodontic subject \\
\hline 353 & $\begin{array}{l}\text { Guay DRP. Rasagiline (TVP-1012): A new selective monoamine oxidase inhibitor for Parkinson's disease. American Journal Geriatric Pharmacotherapy. } \\
\text { 2006;4(4):330-46. }\end{array}$ & Non-orthodontic subject \\
\hline 354 & $\begin{array}{l}\text { Guo Y, Zhou S, Liu F, Zhang B. CYP2E1 Rsal/Pstl polymorphisms contributed to oral cancer susceptibility: a meta-analysis. International journal of clinical } \\
\text { and experimental pathology. 2015;8(11):14685-92. }\end{array}$ & Non-orthodontic subject \\
\hline 355 & Gupta A, Mam C. Helicomania: The mania with insight. Journal of Internal Medicine of India. 2005;8(1):11-9. & Non-orthodontic subject \\
\hline 356 & $\begin{array}{l}\text { Gurani SF, Di Carlo G, Cattaneo PM, Thorn JJ, Pinholt EM. Effect of Head and Tongue Posture on the Pharyngeal Airway Dimensions and Morphology in } \\
\text { Three-Dimensional Imaging: a Systematic Review. Journal of oral \& maxillofacial research. } 2016 ; 7(1): \mathrm{e} 1 .\end{array}$ & Non-orthodontic subject \\
\hline 357 & Gurav AN. The implication of periodontitis in vascular endothelial dysfunction. European Journal of Clinical Investigation. 2014;44(10):1000-9. & Non-orthodontic subject \\
\hline 358 & $\begin{array}{l}\text { Gutierrez-Alvarez AM. Use of anticonvulsive drugs during pregnancy and the risk of malformations in the newborn a meta-analysis. Revista De } \\
\text { Neurologia. 2003;37(11):1022-8. }\end{array}$ & Non-orthodontic subject \\
\hline 359 & Gysin C. Indications of pediatric tonsillectomy. ORL. 2013;75(3):193-202. & Non-orthodontic subject \\
\hline 360 & Habashy D, Hodson EM, Craig JC. Interventions for steroid-resistant nephrotic syndrome: A systematic review. Pediatric Nephrology. $2003 ; 18(9): 906-12$. & Non-orthodontic subject \\
\hline 361 & Hackshaw A, Rodeck C, Boniface S. Maternal smoking in pregnancy and birth defects: a systematic review based on 173687 malformed cases and 11.7 & Non-orthodontic subject \\
\hline
\end{tabular}




\begin{tabular}{|c|c|c|}
\hline & million controls. Human reproduction update. 2011;17(5):589-604. & \\
\hline 362 & $\begin{array}{l}\text { Haddad EM, McAlister VC, Renouf E, Malthaner R, Kjaer MS, Gluud LL. Cyclosporin versus tacrolimus for liver transplanted patients. Cochrane Database } \\
\text { of Systematic Reviews. 2006(4). }\end{array}$ & Non-orthodontic subject \\
\hline 363 & $\begin{array}{l}\text { Haga S, Nakaoka H, Yamaguchi T, Yamamoto K, Kim Yl, Samoto H, et al. A genome-wide association study of third molar agenesis in Japanese and } \\
\text { Korean populations. Journal of human genetics. 2013;58(12):799-803. }\end{array}$ & Non-orthodontic subject \\
\hline 364 & $\begin{array}{l}\text { Hamedi Sangsari A, Sadr-Eshkevari P, Al-Dam A, Friedrich RE, Freymiller E, Rashad A. Surgically Assisted Rapid Palatomaxillary Expansion With or } \\
\text { Without Pterygomaxillary Disjunction: A Systematic Review and Meta-Analysis. J Oral Maxillofac Surg. 2016;74(2):338-48. }\end{array}$ & Non-orthodontic subject \\
\hline 365 & $\begin{array}{l}\text { Han MX, Ding C, Kyung HM. Genetic polymorphisms in pattern recognition receptors and risk of periodontitis: Evidence based on } 12,793 \text { subjects. Human } \\
\text { immunology. } 2015 ; 76(7): 496-504 \text {. }\end{array}$ & Non-orthodontic subject \\
\hline 366 & Haram K, Søfteland E, Bukowski R. Intrauterine growth restriction. International Journal of Gynecology and Obstetrics. 2006;93(1):5-12. & Non-orthodontic subject \\
\hline 367 & Hardinger KL, Koch MJ, Brennan DC. Current and future immunosuppressive strategies in renal transplantation. Pharmacotherapy. 2004;24(9):1159-76. & Non-orthodontic subject \\
\hline 368 & $\begin{array}{l}\text { Hardwicke JT, Landini G, Richard BM. Fistula incidence after primary cleft palate repair: A systematic review of the literature. Plastic and reconstructive } \\
\text { surgery. 2014;134(4):618e-27e. }\end{array}$ & Non-orthodontic subject \\
\hline 369 & $\begin{array}{l}\text { Harris AT, Mettias B, Lesser TH. Pooled analysis of the evidence for open cavity, combined approach and reconstruction of the mastoid cavity in primary } \\
\text { cholesteatoma surgery. The Journal of laryngology and otology. } 2016 ; 130(3): 235-41 \text {. }\end{array}$ & Non-orthodontic subject \\
\hline 370 & Hasson H, Ismail Al, Neiva G. Home-based chemically-induced whitening of teeth in adults. Cochrane Database of Systematic Reviews. 2006(4). & Non-orthodontic subject \\
\hline 371 & $\begin{array}{l}\text { Hausen H, Watt RG, Marinho VC. Oral health promotion reduces plaque and gingival bleeding in the short term: Does oral health promotion improve oral } \\
\text { hygiene and gingival health? Evidence-based dentistry. } 2005 ; 6(2): 31 \text {. }\end{array}$ & Non-orthodontic subject \\
\hline 372 & Hazra A, Kumar Tripathi S. Folic acid revisited. Indian Journal of Pharmacology. 2001;33(5):322-42. & Non-orthodontic subject \\
\hline 373 & $\begin{array}{l}\text { He XC, Jiang XL, Wu GP. Research and progress in gene therapy for cranio-maxillofacial bone remodeling. Journal of Clinical Rehabilitative Tissue } \\
\text { Engineering Research. 2007;11(41):8327-32. }\end{array}$ & Non-orthodontic subject \\
\hline 374 & Henry PJ. Oral implant restoration for enhanced oral function. Clinical and Experimental Pharmacology and Physiology. 2005;32(1-2):123-7. & Non-orthodontic subject \\
\hline 375 & $\begin{array}{l}\text { Herkrath AP, Herkrath FJ, Rebelo MA, Vettore MV. Parental age as a risk factor for non-syndromic oral clefts: a meta-analysis. Journal of dentistry. } \\
2012 ; 40(1): 3-14 \text {. }\end{array}$ & Non-orthodontic subject \\
\hline 376 & $\begin{array}{l}\text { Hermont AP, Oliveira PA, Martins CC, Paiva SM, Pordeus IA, Auad SM. Tooth erosion and eating disorders: a systematic review and meta-analysis. PloS } \\
\text { one. } 2014 ; 9(11) \text { :e111123. }\end{array}$ & Non-orthodontic subject \\
\hline 377 & Ho VC. The use of ciclosporin in psoriasis: A clinical review. British Journal of Dermatology, Supplement. 2004;150(67):1-10. & Non-orthodontic subject \\
\hline 378 & Holt RCL, Webb NJA. Management of nephrotic syndrome in childhood. Current Paediatrics. 2002;12(7):551-60. & Non-orthodontic subject \\
\hline 379 & $\begin{array}{l}\text { Hou T, Gao L, Zheng J, Liu Z, Wu C, Liu Q, et al. Matrix metalloproteinase-1 gene polymorphisms and periodontitis susceptibility: A meta-analysis based } \\
\text { on } 11 \text { case-control studies. Gene. 2013;521(1):111-5. }\end{array}$ & Non-orthodontic subject \\
\hline 380 & $\begin{array}{l}\text { Hsieh YJ, Liao YF. Effects of maxillomandibular advancement on the upper airway and surrounding structures in patients with obstructive sleep apnoea: a } \\
\text { systematic review. The British journal of oral \& maxillofacial surgery. } 2013 ; 51(8): 834-40 \text {. }\end{array}$ & Non-orthodontic subject \\
\hline 381 & $\begin{array}{l}\text { Hu Y, Wang J, Tao H, Wu B, Sun J, Cheng Y, et al. Increased Risk of High-Grade Hemorrhage in Cancer Patients Treated with Gemcitabine: A Meta- } \\
\text { Analysis of } 20 \text { Randomized Controlled Trials. PloS one. 2013;8(9). }\end{array}$ & Non-orthodontic subject \\
\hline 382 & $\begin{array}{l}\text { Hu YY, Liu JH, Jiang GB, Yuan RX, Niu YM, Shen M. Association between interleukin-1 } \beta \text { gene }-511 \mathrm{C}>\mathrm{T} /+3954 \mathrm{C}>\mathrm{T} \text { polymorphisms and aggressive } \\
\text { periodontitis susceptibility: Evidence from a meta-analysis. Medical Science Monitor. 2015;21:1617-24. }\end{array}$ & Non-orthodontic subject \\
\hline 383 & $\begin{array}{l}\text { Hu YY, Qin CQ, Deng MH, Niu YM, Long X. Association between BMP4 rs17563 polymorphism and NSCL/P risk: a meta-analysis. Disease markers. } \\
\text { 2015;2015:763090. }\end{array}$ & Non-orthodontic subject \\
\hline 384 & $\begin{array}{l}\text { Hua F, He H, Ngan P, Bouzid W. Prevalence of peg-shaped maxillary permanent lateral incisors: A meta-analysis. Am J Orthod Dentofacial Orthop } \\
\text { 2013;144(1):97-109. }\end{array}$ & Non-orthodontic subject \\
\hline 385 & $\begin{array}{l}\text { Huang E, Cheng H, Xu M, Shu S, Tang S. Association between single-nucleotide polymorphisms on chromosome 1p22 and } 20 q 12 \text { and nonsyndromic } \\
\text { cleft lip with or without cleft palate: new data in Han Chinese and meta-analysis. Birth defects research Part A, Clinical and molecular teratology. } \\
2012 ; 94(6): 469-76 \text {. }\end{array}$ & Non-orthodontic subject \\
\hline 386 & $\begin{array}{l}\text { Huang W, Jian F, Lai W, Li W, Millett DT, McIntyre GT, et al. Direct versus indirect bonding for bracket placement in orthodontic patients. Cochrane } \\
\text { Database of Systematic Reviews. 2014; (6). }\end{array}$ & Non-orthodontic subject \\
\hline 387 & $\begin{array}{l}\text { Hughes SS, Fiedler S, Zhang L, Kaye A. 22q11.2 duplication syndrome: Guiding medical management. Cleft Palate-Craniofacial Journal. } \\
\text { 2016;53(4):e126. }\end{array}$ & Non-orthodontic subject \\
\hline 388 & $\begin{array}{l}\text { Hutton B, Sharma R, Fergusson D, Tinmouth A, Hebert P, Jamieson J, et al. Use of intravenous immunoglobulin for treatment of recurrent miscarriage: A } \\
\text { systematic review. BJOG: An International Journal of Obstetrics and Gynaecology. } 2007 ; 114(2): 134-42 \text {. }\end{array}$ & Non-orthodontic subject \\
\hline 389 & $\begin{array}{l}\text { Hwang BF, Jaakkola JJ, Guo HR. Water disinfection by-products and the risk of specific birth defects: a population-based cross-sectional study in Taiwan. } \\
\text { Environmental health : a global access science source. } 2008 ; 7: 23 \text {. }\end{array}$ & Non-orthodontic subject \\
\hline 390 & Hwang BF, Jaakkola JJ. Water chlorination and birth defects: a systematic review and meta-analysis. Archives of environmental health. 2003;58(2):83-91. & Non-orthodontic subject \\
\hline 391 & Hwang D, Wang HL. Flap thickness as a predictor of root coverage: A systematic review. Journal of periodontology. 2006;77(10):1625-34. & Non-orthodontic subject \\
\hline 392 & $\begin{array}{l}\text { Iftikhar IH, Hays ER, Iverson MA, Magalang UJ, Maas AK. Effect of oral appliances on blood pressure in obstructive sleep apnea: a systematic review and } \\
\text { meta-analysis. Journal of clinical sleep medicine : JCSM : official publication of the American Academy of Sleep Medicine. 2013;9(2):165-74. }\end{array}$ & Non-orthodontic subject \\
\hline 393 & Imseis HM, lams JD. Glucocorticoid use in patients with preterm premature rupture of the fetal membranes. Seminars in Perinatology. 1996;20(5):439-50. & Non-orthodontic subject \\
\hline 394 & $\begin{array}{l}\text { loannidou E, Malekzadeh T, Dongari-Bagtzoglou A. Effect of periodontal treatment on serum C-reactive protein levels: A systematic review and meta- } \\
\text { analysis. Journal of periodontology. 2006;77(10):1635-42. }\end{array}$ & Non-orthodontic subject \\
\hline 395 & $\begin{array}{l}\text { Izedonmwen OM, Cunningham C, Macfarlane TV. What is the Risk of Having Offspring with Cleft Lip/Palate in Pre-Maternal Obese/Overweight Women } \\
\text { When Compared to Pre-Maternal Normal Weight Women? A Systematic Review and Meta-Analysis. Journal of oral \& maxillofacial research. 2015;6(1):e1. }\end{array}$ & Non-orthodontic subject \\
\hline 396 & $\begin{array}{l}\text { Jaafar SH, Ho JJ, Jahanfar S, Angolkar M. Effect of restricted pacifier use in breastfeeding term infants for increasing duration of breastfeeding. Cochrane } \\
\text { Database Syst Rev 2016(8):Cd007202. }\end{array}$ & Non-orthodontic subject \\
\hline 397 & $\begin{array}{l}\text { Jackson A, Bromley R, Morrow J, Irwin B, Clayton-Smith J. In utero exposure to valproate increases the risk of isolated cleft palate. Archives of Disease in } \\
\text { Childhood: Fetal and Neonatal Edition. 2016;101(3):F207-F11. }\end{array}$ & Non-orthodontic subject \\
\hline 398 & Jain AE, Lacy T. Psychotropic drugs in pregnancy and lactation. Journal of Psychiatric Practice. 2005;11(3):177-91. & Non-orthodontic subject \\
\hline 399 & $\begin{array}{l}\text { Janket SJ, Meurman JH, Nuutinen P, Qvarnström M, Nunn ME, Baird AE, et al. Salivary lysozyme and prevalent coronary heart disease: Possible effects } \\
\text { of oral health on endothelial dysfunction [3]. Arteriosclerosis, Thrombosis, and Vascular Biology. 2006;26(2):433-4. }\end{array}$ & Non-orthodontic subject \\
\hline 400 & $\begin{array}{l}\text { Janssen NG, Weijs WL, Koole R, Rosenberg AJ, Meijer GJ. Tissue engineering strategies for alveolar cleft reconstruction: a systematic review of the } \\
\text { literature. Clinical oral investigations. 2014;18(1):219-26. }\end{array}$ & Non-orthodontic subject \\
\hline 401 & Japanese Society of Hypertension Guidelines for the Management of Hypertension (JSH 2004). Hypertension Research. 2006;29(SUPLL.):S1-S102. & Non-orthodontic subject \\
\hline 402 & $\begin{array}{l}\text { Jatlaoui TC, Riley H, Curtis KM. Safety data for levonorgestrel, ulipristal acetate and Yuzpe regimens for emergency contraception. Contraception. } \\
\text { 2016;93(2):93-112. }\end{array}$ & Non-orthodontic subject \\
\hline 403 & $\begin{array}{l}\text { Jayaraman J, Roberts GJ, King NM, Wong HM. Dental age assessment of southern Chinese using the United Kingdom Caucasian reference dataset. } \\
\text { Forensic science international. 2012;216(1-3):68-72. }\end{array}$ & Non-orthodontic subject \\
\hline 404 & $\begin{array}{l}\text { Jayaraman J, Wong HM, King NM, Roberts GJ. Development of a Reference Data Set (RDS) for dental age estimation (DAE) and testing of this with a } \\
\text { separate Validation Set (VS) in a southern Chinese population. Journal of forensic and legal medicine. 2016;43:26-33. }\end{array}$ & Non-orthodontic subject \\
\hline 405 & $\begin{array}{l}\text { Je Y, Schutz FA, Choueiri TK. Risk of bleeding with vascular endothelial growth factor receptor tyrosine-kinase inhibitors sunitinib and sorafenib: a } \\
\text { systematic review and meta-analysis of clinical trials. The Lancet Oncology. 2009;10(10):967-74. }\end{array}$ & Non-orthodontic subject \\
\hline 406 & Jeffcoat M. The association between osteoporosis and oral bone loss. Journal of periodontology. 2005;76(11 SUPPL.):2125-32. & Non-orthodontic subject \\
\hline 407 & $\begin{array}{l}\text { Ji XW, Wang Y, Cao C, Zhong LJ. Assessment of the link between Vitamin D receptor Taql gene polymorphism and periodontitis: A meta-analysis in a } \\
\text { Chinese population. Genetics and Molecular Research. } 2016 ; 15(4) \text {. }\end{array}$ & Non-orthodontic subject \\
\hline 408 & $\begin{array}{l}\text { Jia Z, Leslie EJ, Cooper ME, Butali A, Standley J, Rigdon J, et al. Replication of } 13 q 31.1 \text { association in nonsyndromic cleft lip with cleft palate in } \\
\text { Europeans. American journal of medical genetics Part A. 2015;167a(5):1054-60. }\end{array}$ & Non-orthodontic subject \\
\hline 409 & $\begin{array}{l}\text { Jiang C, Yin N, Zhao Z, Wu D, Wang Y, Li H, et al. Lack of Association Between MTHFR, MTR, MTRR, and TCN2 Genes and Nonsyndromic CL+/-P in a } \\
\text { Chinese Population: Case-Control Study and Meta-Analysis. Cleft Palate Craniofac J 2015;52(5):579-87. }\end{array}$ & Non-orthodontic subject \\
\hline 410 & $\begin{array}{l}\text { Jiang N, Pan J, Wang L, Duan YZ. No significant association between p53 codon } 72 \text { Arg/Pro polymorphism and risk of oral cancer. Tumour biology : the } \\
\text { journal of the International Society for Oncodevelopmental Biology and Medicine. } 2013 ; 34(1): 587-96 \text {. }\end{array}$ & Non-orthodontic subject \\
\hline 411 & Jin SH, Guan XY, Liang WH, Bai GH, Liu JG. TLR4 polymorphism and periodontitis susceptibility A meta-analysis. Medicine (United States). 2016;95(36). & Non-orthodontic subject \\
\hline 412 & $\begin{array}{l}\text { Johnson CY, Little J. Folate intake, markers of folate status and oral clefts: is the evidence converging? International journal of epidemiology. } \\
2008 ; 37(5): 1041-58 .\end{array}$ & Non-orthodontic subject \\
\hline 413 & $\begin{array}{l}\text { Joubert BR, Felix JF, Yousefi P, Bakulski KM, Just AC, Breton C, et al. DNA Methylation in Newborns and Maternal Smoking in Pregnancy: Gen } \\
\text { Consortium Meta-analysis. American journal of human genetics. 2016;98(4):680-96. }\end{array}$ & Non-orthodontic subject \\
\hline
\end{tabular}




\begin{tabular}{|c|c|c|}
\hline 414 & $\begin{array}{l}\text { Joury E, Bernabe E, Sabbah W, Nakhleh K, Gurusamy K. Systematic review and meta-analysis of randomised controlled trials on the effectiveness of } \\
\text { school-based dental screening versus no screening on improving oral health in children. Journal of dentistry. } 2016 \text {. }\end{array}$ & Non-orthodontic subject \\
\hline 415 & $\begin{array}{l}\text { Kadir A, Mossey PA, Blencowe H, Moorthie S, Lawn JE, Mastroiacovo P, et al. Systematic Review and Meta-analysis of the Birth Prevalence of Orofacial } \\
\text { Clefts in Low- and Middle-Income Countries. Cleft Palate Craniofac J 2016. }\end{array}$ & Non-orthodontic subject \\
\hline 416 & $\begin{array}{l}\text { Kaditis AG, Alvarez MLA, Boudewyns A, Alexopoulos El, Ersu R, Joosten K, et al. Obstructive sleep disordered breathing in 2- to 18-year-old children: } \\
\text { Diagnosis and management. European Respiratory Journal. 2016;47(1):69-94. }\end{array}$ & Non-orthodontic subject \\
\hline 417 & Källén BAJ. Methodological issues in the epidemiological study of the teratogenicity of drugs. Congenital Anomalies. 2005;45(2):44-51. & Non-orthodontic subject \\
\hline 418 & $\begin{array}{l}\text { Kalpidis CDR, Ruben MP. Treatment of intrabony periodontal defects with enamel matrix derivative: A literature review. Journal of periodontology. } \\
\text { 2002;73(11):1360-76. }\end{array}$ & Non-orthodontic subject \\
\hline 419 & $\begin{array}{l}\text { Kao RT, Nares S, Reynolds MA. Periodontal regeneration - intrabony defects: A systematic review from the AAP regeneration workshop. Journal of } \\
\text { periodontology. 2015;86:S77-S104. }\end{array}$ & Non-orthodontic subject \\
\hline 420 & $\begin{array}{l}\text { Kasiakou SK, Sermaides GJ, Michalopoulos A, Soteriades ES, Falagas ME. Continuous versus intermittent intravenous administration of antibiotics: A } \\
\text { meta-analysis of randomised controlled trials. Lancet Infectious Diseases. } 2005 ; 5(9): 581-9 .\end{array}$ & Non-orthodontic subject \\
\hline 421 & $\begin{array}{l}\text { Kaur S, Bright R, Proudman SM, Bartold PM. Does periodontal treatment influence clinical and biochemical measures for rheumatoid arthritis? A } \\
\text { systematic review and meta-analysis. Seminars in Arthritis and Rheumatism. 2015;44(2):113-22. }\end{array}$ & Non-orthodontic subject \\
\hline 422 & $\begin{array}{l}\text { Ke J, Zhong R, Zhang T, Liu L, Rui R, Shen N, et al. Replication study in Chinese population and meta-analysis supports association of the } 5 p 15.33 \text { locus } \\
\text { with lung cancer. PloS one. 2013;8(4):e62485. }\end{array}$ & Non-orthodontic subject \\
\hline 423 & $\begin{array}{l}\text { Kellesarian SV, Malignaggi VR, Abduljabbar T, Vohra F, Malmstrom H, Romanos GE, et al. Efficacy of scaling and root planing with and without adjunct } \\
\text { antimicrobial photodynamic therapy on the expression of cytokines in the gingival crevicular fluid of patients with periodontitis: A systematic review. } \\
\text { Photodiagnosis and Photodynamic Therapy. } 2016 ; 16: 76-84 \text {. }\end{array}$ & Non-orthodontic subject \\
\hline 424 & $\begin{array}{l}\text { Kemp DE. Managing the side effects associated with commonly used treatments for bipolar depression. Journal of Affective Disorders. 2014;169(S1):S34- } \\
\text { S44. }\end{array}$ & Non-orthodontic subject \\
\hline 425 & $\begin{array}{l}\text { Khalaf K, Miskelly J, Voge E, Macfarlane TV. Prevalence of hypodontia and associated factors: A systematic review and meta-analysis. J Orthod } \\
2014 ; 41(4): 299-316 .\end{array}$ & Non-orthodontic subject \\
\hline 426 & $\begin{array}{l}\text { Khan KS, Wykes C, Gee H. Benzodiazepine use in pregnancy and major malformations or oral clefts. Quality of primary studies must influence inferences } \\
\text { made from meta-analyses. BMJ (Clinical research ed). } 1999 ; 319(7214): 919 .\end{array}$ & Non-orthodontic subject \\
\hline 427 & Khan SQ. Dental caries in Arab League countries: a systematic review and meta-analysis. International dental journal. 2014;64(4):173-80. & Non-orthodontic subject \\
\hline 428 & $\begin{array}{l}\text { Kher A, Bauersachs R, Nielsen JD. The management of thrombosis in pregnancy: Role of low-molecular-weight heparin. Thrombosis and Haemostasis. } \\
2007 ; 97(4): 505-13 \text {. }\end{array}$ & Non-orthodontic subject \\
\hline 429 & $\begin{array}{l}\text { Kim SG, Solomon C. Cost-effectiveness of endodontic molar retreatment compared with fixed partial dentures and single-tooth implant alternatives. } \\
\text { Journal of endodontics. } 2011 ; 37(3): 321-5 \text {. }\end{array}$ & Non-orthodontic subject \\
\hline 430 & $\begin{array}{l}\text { Kirkpatrick CL. Now and then: Linking public health research to bioarchaeological methodology. American Journal of Physical Anthropology. } \\
\text { 2015;156:188. }\end{array}$ & Non-orthodontic subject \\
\hline 431 & $\begin{array}{l}\text { Kisely S, Sawyer E, Siskind D, Lalloo R. The oral health of people with anxiety and depressive disorders - A systematic review and meta-analysis. Journal } \\
\text { of Affective Disorders. 2016;200:119-32. }\end{array}$ & Non-orthodontic subject \\
\hline 432 & $\begin{array}{l}\text { Ko HY, Lu HK. Systematic review of the clinical performance of connective tissue graft and guided tissue regeneration in the treatment of gingival } \\
\text { recessions of miller's classification grades I and II. Journal of Experimental and Clinical Medicine. } 2010 ; 2(2): 63-71 \text {. }\end{array}$ & Non-orthodontic subject \\
\hline 433 & $\begin{array}{l}\text { Konopka T, Banach J, Bachanek T, Kurnatowska A, Mielczarek A, Górska R. Clinical efficacy comparison of oscillation/rotation/pulsation and sonic } \\
\text { electric toothbrushes - Metaanalysis. Dental and Medical Problems. 2013;50(4):432-40. }\end{array}$ & Non-orthodontic subject \\
\hline 434 & $\begin{array}{l}\text { Konopka T, Iwanicka-Grzegorek E, Mielczarek A. Stabilized stannous fluoride dentifrice as a dental plaque inhibitor and an antigingivitis agent: Meta- } \\
\text { analysis. Dental and Medical Problems. } 2016 ; 53(2): 260-7 \text {. }\end{array}$ & Non-orthodontic subject \\
\hline 435 & $\begin{array}{l}\text { Koodaryan R, Hafezeqoran A. Evaluation of Implant Collar Surfaces for Marginal Bone Loss: A Systematic Review and Meta-Analysis. BioMed Research } \\
\text { International. 2016;2016. }\end{array}$ & Non-orthodontic subject \\
\hline 436 & Koren G. Is ondansetron safe for use during pregnancy? Canadian Family Physician. 2012;58(10):1092-3. & Non-orthodontic subject \\
\hline 437 & $\begin{array}{l}\text { Kossowsky J, Donado C, Berde CB. Immediate Rescue Designs in Pediatric Analgesic Trials A Systematic Review and Meta-analysis. Anesthesiology. } \\
\text { 2015;122(1):150-71. }\end{array}$ & Non-orthodontic subject \\
\hline 438 & Kothare SV, Kaleyias J. The adverse effects of antiepileptic drugs in children. Expert Opinion on Drug Safety. 2007;6(3):251-65. & Non-orthodontic subject \\
\hline 439 & $\begin{array}{l}\text { Koutsilieri E, Riederer P, du Plessis S, Scheller C. A short review on the relation between the dopamine transporter 10/10-repeat allele and ADHD: } \\
\text { Implications for HIV infection. ADHD Attention Deficit and Hyperactivity Disorders. 2014;6(3):203-9. }\end{array}$ & Non-orthodontic subject \\
\hline 440 & $\begin{array}{l}\text { Kozer E, Nikfar S, Costei A, Boskovic R, Nulman I, Koren G, et al. Aspirin in early pregnancy is not associated with an increased risk of congenital } \\
\text { anomalies - Meta-analysis. Evidence-based Obstetrics and Gynecology. 2003;5(3):113-4. }\end{array}$ & Non-orthodontic subject \\
\hline 441 & $\begin{array}{l}\text { Kreutzer K, Storck K, Weitz J. Current evidence regarding prophylactic antibiotics in head and neck and maxillofacial surgery. BioMed Research } \\
\text { International. 2014;2014. }\end{array}$ & Non-orthodontic subject \\
\hline 442 & $\begin{array}{l}\text { Kuo CL, Tsao YH, Cheng HM, Lien CF, Hsu CH, Huang CY, et al. Grommets for otitis media with effusion in children with cleft palate: A systematic } \\
\text { review. Pediatrics. 2014;134(5):983-94. }\end{array}$ & Non-orthodontic subject \\
\hline 443 & $\begin{array}{l}\text { Kusters DM, Lahsinoui HH, Van De Post JAM, Wiegman A, Wijburg FA, Kastelein JJP, et al. Statin use during pregnancy: A systematic review and meta- } \\
\text { analysis. Expert Review of Cardiovascular Therapy. 2012;10(3):363-78. }\end{array}$ & Non-orthodontic subject \\
\hline 444 & $\begin{array}{l}\text { Lamont RF, Jaggat AN. Emerging drug therapies for preventing spontaneous preterm labor and preterm birth. Expert Opinion on Investigational Drugs. } \\
2007 ; 16(3): 337-45 \text {. }\end{array}$ & Non-orthodontic subject \\
\hline 445 & Lassi ZS, Imam AM, Dean SV, Bhutta ZA. Preconception care: Preventing and treating infections. Reproductive Health. $2014 ; 11$. & Non-orthodontic subject \\
\hline 446 & $\begin{array}{l}\text { Lauritsen K. Cyclosporin in inflammatory bowel disease: Still an experimental option? European Journal of Gastroenterology and Hepatology. } \\
\text { 1994;6(6):495-8. }\end{array}$ & Non-orthodontic subject \\
\hline 447 & $\begin{array}{l}\text { Lavigne JV, Faierroutman J. Psychological Adjustment to Pediatric Physical Disorders - a Meta-Analytic Review. Journal of pediatric psychology. } \\
\text { 1992;17(2):133-57. }\end{array}$ & Non-orthodontic subject \\
\hline 448 & $\begin{array}{l}\text { Leira Y, Seoane J, Blanco M, Rodríguez-Yáñez M, Takkouche B, Blanco J, et al. Association between periodontitis and ischemic stroke: a systematic } \\
\text { review and meta-analysis. European Journal of Epidemiology. 2016:1-11. }\end{array}$ & Non-orthodontic subject \\
\hline 449 & $\begin{array}{l}\text { Leonardi-Bee J, Britton J, Venn A. Secondhand Smoke and Adverse Fetal Outcomes in Nonsmoking Pregnant Women: A Meta-analysis. Pediatrics. } \\
\text { 2011;127(4):734-41. }\end{array}$ & Non-orthodontic subject \\
\hline 450 & $\begin{array}{l}\text { Leschziner GD, Andrew T, Pirmohamed M, Johnson MR. ABCB1 genotype and PGP expression, function and therapeutic drug response: A critical review } \\
\text { and recommendations for future research. Pharmacogenomics Journal. 2007;7(3):154-79. }\end{array}$ & Non-orthodontic subject \\
\hline 451 & $\begin{array}{l}\text { Leslie EJ, Standley J, Compton J, Bale S, Schutte BC, Murray JC. Comparative analysis of IRF6 variants in families with Van der Woude syndrome and } \\
\text { popliteal pterygium syndrome using public whole-exome databases. Genetics in Medicine. 2013;15(5):338-44. }\end{array}$ & Non-orthodontic subject \\
\hline 452 & Levey L, Ragan K, Hower-Hartley A, Newport DJ, Stowe ZN. Psychiatric disorders in pregnancy. Neurologic Clinics. 2004;22(4 SPEC. ISS.):863-93. & Non-orthodontic subject \\
\hline 453 & $\begin{array}{l}\text { Li C, Li Z, Zeng X, Guo Z. Is a polymorphism in } 10 q 25 \text { associated with non-syndromic cleft lip with or without cleft palate? A meta-analysis based on } \\
\text { limited evidence. The British journal of oral \& maxillofacial surgery. } 2015 ; 53(1): 8-12 \text {. }\end{array}$ & Non-orthodontic subject \\
\hline 454 & $\begin{array}{l}\text { Li C, Su N, Yang X, Yang X, Shi Z, Li L. Ultrasonography for detection of disc displacement of temporomandibular joint: A systematic review and meta- } \\
\text { analysis. Journal of Oral and Maxillofacial Surgery. } 2012 ; 70(6): 1300-9 \text {. }\end{array}$ & Non-orthodontic subject \\
\hline 455 & $\begin{array}{l}\text { Li C, Yang X, Pan J, Shi Z, Li L. Graft for prevention of frey syndrome after parotidectomy: A systematic review and meta-analysis of randomized } \\
\text { controlled trials. Journal of Oral and Maxillofacial Surgery. 2013;71(2):419-27. }\end{array}$ & Non-orthodontic subject \\
\hline 456 & $\begin{array}{l}\text { Li C, Yin Z, Wu W, Li X, Zhou B. Genetic variants in TERT-CLPTM1L genetic region associated with several types of cancer: a meta-analysis. Gene. } \\
\text { 2013;526(2):390-9. }\end{array}$ & Non-orthodontic subject \\
\hline 457 & $\begin{array}{l}\text { Li C, Zhang Y, Lv J, Shi Z. Inferior or double joint spaces injection versus superior joint space injection for temporomandibular disorders: A systematic } \\
\text { review and meta-analysis. Journal of Oral and Maxillofacial Surgery. 2012;70(1):37-44. }\end{array}$ & Non-orthodontic subject \\
\hline 458 & $\begin{array}{l}\text { Li GC, Jiang YB. Amelioration of motor function with low-molecular weight heparin in patients with acute cerebral infarction. Chinese Journal of Clinical } \\
\text { Rehabilitation. } 2004 ; 8(31): 6840-2 \text {. }\end{array}$ & Non-orthodontic subject \\
\hline 459 & $\begin{array}{l}\text { Li J, Huang Z, Mei L, Li G, Li H. Anti-Caries Effect of Arginine-Containing Formulations in vivo: A Systematic Review and Meta-Analysis. Caries research. } \\
\text { 2015;49(6):606-17. }\end{array}$ & Non-orthodontic subject \\
\hline 460 & $\begin{array}{l}\text { Li L, Deng C, Chen S, Zhang S, Wu Z, Hu C, et al. Meta-analysis: Diagnostic accuracy of anti-carbamylated protein antibody for rheumatoid arthritis. PloS } \\
\text { one. 2016;11(7). }\end{array}$ & Non-orthodontic subject \\
\hline 461 & $\begin{array}{l}\text { Li LW, Wong HM, Sun L, Wen YF, McGrath CP. Anthropometric measurements and periodontal diseases in children and adolescents: a systematic review } \\
\text { and meta-analysis. Advances in nutrition (Bethesda, Md). 2015;6(6):828-41. }\end{array}$ & Non-orthodontic subject \\
\hline 462 & Li Q, Hao S, Fang J, Xie J, Kong XH, Yang JX. Effect of non-surgical periodontal treatment on glycemic control of patients with diabetes: A meta-analysis & Non-orthodontic subject \\
\hline
\end{tabular}




\begin{tabular}{|c|c|c|}
\hline & of randomized controlled trials. Trials. 2015;16(1). & \\
\hline 463 & $\begin{array}{l}\text { Li SM, Guo LW, Ding L. Periocline versus yakang for chronic periodontitis in adults: A meta-analysis. Chinese Journal of Evidence-Based Medicine. } \\
2013 ; 13(2): 224-30 \text {. }\end{array}$ & Non-orthodontic subject \\
\hline 464 & Li W, Zhu Y, Singh P, Ajmera DH, Song J, Ji P. Association of common variants in MMPs with periodontitis risk. Disease markers. 2016;2016. & Non-orthodontic subject \\
\hline 465 & $\begin{array}{l}\text { Li XY, Lin L, Pan YP, Guo LC. Effect of local application of metronidazole with scaling and root planing: A meta-analysis. Chinese Journal of Evidence- } \\
\text { Based Medicine. } 2009 ; 9(11): 1226-30 \text {. }\end{array}$ & Non-orthodontic subject \\
\hline 466 & $\begin{array}{l}\text { Li Z, Jun Y, Zhong-bao R, Jie L, Jian-ming L. Association between MTHFR C677T polymorphism and congenital heart disease A family-based meta- } \\
\text { analysis. Herz. 2015;40:160-7. }\end{array}$ & Non-orthodontic subject \\
\hline 467 & $\begin{array}{l}\text { Li ZX, Gao ZL, Wang JN, Guo QH. Maternal Coffee Consumption During Pregnancy and Neural Tube Defects in Offspring: A Meta-Analysis. Fetal and } \\
\text { Pediatric Pathology. 2016;35(1):1-9. }\end{array}$ & Non-orthodontic subject \\
\hline 468 & $\begin{array}{l}\text { Lichtenstein GR, Abreu MT, Cohen R, Tremaine W. American gastroenterological association institute technical review on corticosteroids, } \\
\text { immunomodulators, and infliximab in inflammatory bowel disease. Gastroenterology. 2006;130(3):940-87. }\end{array}$ & Non-orthodontic subject \\
\hline 469 & Lidral AC, Moreno LM. Progress toward discerning the genetics of cleft lip. Current opinion in pediatrics. 2005;17(6):731-9. & Non-orthodontic subject \\
\hline 470 & $\begin{array}{l}\text { Lie RT, Lyngstadaas A, Orstavik KH, Bakketeig LS, Jacobsen G, Tanbo T. Birth defects in children conceived by ICSI compared with children conceived } \\
\text { by other IVF-methods; a meta-analysis. International journal of epidemiology. } 2005 ; 34(3): 696-701 .\end{array}$ & Non-orthodontic subject \\
\hline 471 & $\begin{array}{l}\text { Lin S, McKenna SJ, Yao CF, Chen YR, Chen C. Effects of Hypotensive Anesthesia on Reducing Intraoperative Blood Loss, Duration of Operation, and } \\
\text { Quality of Surgical Field During Orthognathic Surgery: A Systematic Review and Meta-Analysis of Randomized Controlled Trials. J Oral Maxillofac Surg. } \\
2016 .\end{array}$ & Non-orthodontic subject \\
\hline 472 & Little J, Cardy A, Munger RG. Tobacco smoking and oral clefts : a meta-analysis / Julian Little, Amanda Cardy and Ronald G. Munger. 2003. & Non-orthodontic subject \\
\hline 473 & Little J, Cardy A, Munger RG. Tobacco smoking and oral clefts: a meta-analysis. Bulletin of the World Health Organization. 2004;82(3):213-8. & Non-orthodontic subject \\
\hline 474 & $\begin{array}{l}\text { Liu CL, Zang XX, Wang C, Kong YL, Zhang H, Zhang HY. Association between CLPTM1L-TERT rs401681 polymorphism and risk of pancreatic cancer: a } \\
\text { meta-analysis. Clinical and experimental medicine. } 2015 ; 15(4): 477-82 \text {. }\end{array}$ & Non-orthodontic subject \\
\hline 475 & $\begin{array}{l}\text { Liu L, Wei Z, Sun Z, Yin X. The relationship between infection of human papilloma virus and risk of chinese oral squamous cell carcinoma. International } \\
\text { journal of clinical and experimental medicine. } 2016 ; 9(6): 11680-3 \text {. }\end{array}$ & Non-orthodontic subject \\
\hline 476 & $\begin{array}{l}\text { Liu LH, Li EM, Zhong SL, Li YQ, Yang ZY, Kang R, et al. Chronic periodontitis and the risk of erectile dysfunction: a systematic review and meta-analysis. } \\
\text { International Journal of Impotence Research. 2016. }\end{array}$ & Non-orthodontic subject \\
\hline 477 & $\begin{array}{l}\text { Liu LL, Guo FL, Gu BY. Association between the T538C polymorphism in bone morphogenetic protein } 4 \text { and the risk of non-Syndromic cleft lip with or } \\
\text { without cleft palate: A meta-analysis. Chinese Journal of Evidence-Based Medicine. } 2015 ; 15(6): 633-8 \text {. }\end{array}$ & Non-orthodontic subject \\
\hline 478 & $\begin{array}{l}\text { Liu Q, Jiao Y, Zhao Y, Wang Y, Li J, Ma S, et al. Tea consumption reduces the risk of oral cancer: A systematic review and meta-analysis. International } \\
\text { journal of clinical and experimental medicine. 2016;9(2):2688-97. }\end{array}$ & Non-orthodontic subject \\
\hline 479 & $\begin{array}{l}\text { Liu Y, Bai N, Song G, Zhang X, Hu J, Zhu S, et al. Open versus closed treatment of unilateral moderately displaced mandibular condylar fractures: a meta- } \\
\text { analysis of randomized controlled trials. Oral surgery, oral medicine, oral pathology and oral radiology. 2013;116(2):169-73. }\end{array}$ & Non-orthodontic subject \\
\hline 480 & $\begin{array}{l}\text { Liu Z, Liu Y, Song Y, Zhang X, Wang S, Wang Z. Systemic oxidative stress biomarkers in chronic periodontitis: A meta-analysis. Disease markers. } \\
\text { 2014;2014. }\end{array}$ & Non-orthodontic subject \\
\hline 481 & Lo A, Alloway RR. Strategies to reduce toxicities and improve outcomes in renal transplant recipients. Pharmacotherapy. 2002;22(3 II):316-28. & Non-orthodontic subject \\
\hline 482 & Loesche WJ. Role of anaerobic bacteria in periodontal disease. Annals of Otology, Rhinology and Laryngology. 1991;100(9 II SUPPL. 154$): 43-5$. & Non-orthodontic subject \\
\hline 483 & Loesche WJ. The diagnosis and treatment of anaerobic periodontal infections. Infections in Medicine. 1998;15(11):788-90+92-97. & Non-orthodontic subject \\
\hline 484 & $\begin{array}{l}\text { Lohmander A, Olsson M. Methodology for Perceptual Assessment of Speech in Patients with Cleft Palate: A Critical Review of the Literature. Cleft Palate- } \\
\text { Craniofacial Journal. 2004;41(1):64-70. }\end{array}$ & Non-orthodontic subject \\
\hline 485 & $\begin{array}{l}\text { Long H, Zhou Y, Liao L, Pyakurel U, Wang Y, Lai W. Coronectomy vs. total removal for third molar extraction: a systematic review. Journal of dental } \\
\text { research. 2012;91(7):659-65. }\end{array}$ & Non-orthodontic subject \\
\hline 486 & $\begin{array}{l}\text { Long H, Zhou Y, Ye N, Liao L, Jian F, Wang Y, et al. Diagnostic accuracy of CBCT for tooth fractures: a meta-analysis. Journal of dentistry. } \\
\text { 2014;42(3):240-8. }\end{array}$ & Non-orthodontic subject \\
\hline 487 & $\begin{array}{l}\text { Lowe GDO. Dental Disease, Coronary Heart Disease and Stroke, and Inflammatory Markers: What Are the Associations, and What Do They Mean? } \\
\text { Circulation. 2004;109(9):1076-8. }\end{array}$ & Non-orthodontic subject \\
\hline 488 & $\begin{array}{l}\text { Lu XC, Yu W, Tao Y, Zhao PL, Li K, Tang LJ, et al. Contribution of transforming growth factor alpha polymorphisms to nonsyndromic orofacial clefts: a } \\
\text { HuGE review and meta-analysis. American journal of epidemiology. } 2014 ; 179(3): 267-81 \text {. }\end{array}$ & Non-orthodontic subject \\
\hline 489 & $\begin{array}{l}\text { Ludwig KU, Ahmed ST, Bohmer AC, Sangani NB, Varghese S, Klamt J, et al. Meta-analysis Reveals Genome-Wide Significance at 15q13 for } \\
\text { Nonsyndromic Clefting of Both the Lip and the Palate, and Functional Analyses Implicate GREM1 As a Plausible Causative Gene. PLoS genetics. } \\
\text { 2016;12(3):e1005914. }\end{array}$ & Non-orthodontic subject \\
\hline 490 & $\begin{array}{l}\text { Ludwig KU, Böhmer AC, Peters H, Graf D, Gültepe P, AlChawa T, et al. Identification of a novel susceptibility locus for nonsyndromic cleft lip and palate at } \\
\text { chromosome 15q13. Medizinische Genetik. 2014;26(1):80. }\end{array}$ & Non-orthodontic subject \\
\hline 491 & $\begin{array}{l}\text { Ludwig KU, Bohmer AC, Rubini M, Mossey PA, Herms S, Nowak S, et al. Strong association of variants around FOXE1 and orofacial clefting. Journal of } \\
\text { dental research. 2014;93(4):376-81. }\end{array}$ & Non-orthodontic subject \\
\hline 492 & $\begin{array}{l}\text { Ludwig KU, Böhmer AC, Schuenke H, Klamt J, Hecker J, Barth S, et al. Nonsyndromic cleft lip with or without cleft palate: Genomewide imputation } \\
\text { identifies four novel risk loci and an enrichment of association signals in enhancer datasets relevant to craniofacial development. Medizinische Genetik. } \\
2015 ; 27(1): 106 \text {. }\end{array}$ & Non-orthodontic subject \\
\hline 493 & $\begin{array}{l}\text { Ludwig KU, Herms S, Knapp M, Nothen MM, Mangold E. Genome-Wide Meta-Analysis of Nonsyndromic Cleft Lip With or Without Cleft Palate (NSCL/P) } \\
\text { Identifies Multiple New Loci. American Journal of Medical Genetics Part A. 2014;164(4):880-. }\end{array}$ & Non-orthodontic subject \\
\hline 494 & $\begin{array}{l}\text { Ludwig KU, Mangold E, Herms S, Nowak S, Reutter H, Paul A, et al. Genome-wide meta-analyses of nonsyndromic cleft lip with or without cleft palate } \\
\text { identify six new risk loci. Nature genetics. 2012;44(9):968-71. }\end{array}$ & Non-orthodontic subject \\
\hline 495 & $\begin{array}{l}\text { Ludwig KU, Wahle P, Reutter H, Paredes-Zenteno M, Munoz-Jimenez SG, Ortiz-Lopez R, et al. Evaluating eight newly identified susceptibility loci for } \\
\text { nonsyndromic cleft lip with or without cleft palate in a Mesoamerican population. Birth defects research Part A, Clinical and molecular teratology. } \\
2014 ; 100(1): 43-7 \text {. }\end{array}$ & Non-orthodontic subject \\
\hline 496 & $\begin{array}{l}\text { Lukacs JR. Meta-analyses reveal direction and timing of sex and gender differences in oral health. American Journal of Physical Anthropology. } \\
\text { 2012;147:197. }\end{array}$ & Non-orthodontic subject \\
\hline 497 & $\begin{array}{l}\text { Luo X, Lamsal LP, Xu WJ, Lu J, Lu YJ, Shen Y, et al. Genetic variant in CLPTM1L confers reduced risk of lung cancer: a replication study in Chinese and } \\
\text { a meta-analysis. Asian Pacific journal of cancer prevention : APJCP. 2014;15(21):9241-7. }\end{array}$ & Non-orthodontic subject \\
\hline 498 & $\begin{array}{l}\text { Luo YL, Cheng YL, Ye P, Wang W, Gao XH, Chen Q. Association between MTHFR polymorphisms and orofacial clefts risk: a meta-analysis. Birth defects } \\
\text { research Part A, Clinical and molecular teratology. 2012;94(4):237-44. }\end{array}$ & Non-orthodontic subject \\
\hline 499 & $\begin{array}{l}\text { Luque-Martinez I, Reis A, Schroeder M, Munoz MA, Loguercio AD, Masterson D, et al. Comparison of efficacy of tray-delivered carbamide and hydrogen } \\
\text { peroxide for at-home bleaching: a systematic review and meta-analysis. Clinical oral investigations. 2016;20(7):1419-33. }\end{array}$ & Non-orthodontic subject \\
\hline 500 & $\begin{array}{l}\text { Luteijn JM, Brown MJ, Dolk H. Influenza and congenital anomalies: a systematic review and meta-analysis. Human reproduction (Oxford, England). } \\
\text { 2014;29(4):809-23. }\end{array}$ & Non-orthodontic subject \\
\hline 501 & $\begin{array}{l}\text { Lynch SE, Lavin PT, Genco RJ, Beasley WG, Wisner-Lynch LA. New composite endpoints to assess efficacy in periodontal therapy clinical trials. Journal } \\
\text { of periodontology. } 2006 ; 77(8): 1314-22 \text {. }\end{array}$ & Non-orthodontic subject \\
\hline 502 & $\begin{array}{l}\text { Ma J, Jiang H, Liang L. Interpositional arthroplasty versus reconstruction arthroplasty for temporomandibular joint ankylosis: A systematic review and } \\
\text { meta-analysis. J Craniomaxillofac Surg 2015;43(7):1202-7. }\end{array}$ & Non-orthodontic subject \\
\hline 503 & $\begin{array}{l}\text { Ma L, Chu WM, Zhu J, Wu YN, Wang ZL. Interleukin-1 } \beta \text { (3953/4) C } \rightarrow \text { T polymorphism increases the risk of chronic periodontitis in Asians: Evidence from a } \\
\text { meta-analysis of } 20 \text { case-control studies. Archives of Medical Science. 2015;11(2):267-73. }\end{array}$ & Non-orthodontic subject \\
\hline 504 & $\begin{array}{l}\text { Maarse W, Berge S, Pistorius L, Barneveld T, Kon M, Breugem C, et al. Diagnostic accuracy of transabdominal ultrasound in detecting prenatal cleft lip } \\
\text { and palate: a systematic review. Ultrasound in Obstetrics and Gynecology. 2010; 35(4):[495-502 pp.]. }\end{array}$ & Non-orthodontic subject \\
\hline 505 & $\begin{array}{l}\text { MacDonald DS. A systematic review of the literature of nevoid basal cell carcinoma syndrome affecting East Asians and North Europeans. Oral surgery, } \\
\text { oral medicine, oral pathology and oral radiology. } 2015 ; 120(3): 396-407 .\end{array}$ & Non-orthodontic subject \\
\hline 506 & $\begin{array}{l}\text { MacDonald-Jankowski DS, Yeung R, Lee KM, Li TK. Odontogenic myxomas in the Hong Kong Chinese: clinico-radiological presentation and systematic } \\
\text { review. Dento maxillo facial radiology. 2002;31(2):71-83. }\end{array}$ & Non-orthodontic subject \\
\hline 507 & $\begin{array}{l}\text { Machado E, Machado P, Cunali PA. Use of chondroitin sulphate and glucosamine sulphate in degenerative changes in TMJ: A systematic review. Dental } \\
\text { Press J Orthod 2012;17(4):19.e1-.e5. }\end{array}$ & Non-orthodontic subject \\
\hline 508 & Mahadevan U. Fertility and pregnancy in the patient with inflammatory bowel disease. Gut. 2006;55(8):1198-206. & Non-orthodontic subject \\
\hline 509 & $\begin{array}{l}\text { Mangold E, Böhmer AC, Ishorst N, Hofmann A, Hoebel AK, Gültepe } P \text {, et al. Sequencing the GRHL3 coding region reveals rare truncating mutations and } \\
\text { the first common susceptibility variant for nonsyndromic cleft palate. Medizinische Genetik. 2016;28(1):101. }\end{array}$ & Non-orthodontic subject \\
\hline 510 & Manickam PV, Shott SR, Boss EF, Cohen AP, Meinzen-Derr JK, Amin RS, et al. Systematic review of site of obstruction identification and non-CPAP & Non-orthodontic subject \\
\hline
\end{tabular}




\begin{tabular}{|c|c|c|}
\hline & treatment options for children with persistent pediatric obstructive sleep apnea. Laryngoscope. 2016;126(2):491-500. & \\
\hline 511 & $\begin{array}{l}\text { Manipal S, Hussain S, Wadgave U, Duraiswamy P, Ravi K. The Mouthwash War - Chlorhexidine vs. Herbal Mouth Rinses: A Meta-Analysis. Journal of } \\
\text { clinical and diagnostic research : JCDR. 2016;10(5):Zc81-3. }\end{array}$ & Non-orthodontic subject \\
\hline 512 & $\begin{array}{l}\text { Marazita ML, Murray JC, Cooper M, Goldstein T, Schultz R, Daak-Hirsch S, et al. Meta-analysis of } 11 \text { genome scans for cleft lip with or without cleft } \\
\text { palate. American journal of human genetics. } 2003 ; 73(5): 177-\text {. }\end{array}$ & Non-orthodontic subject \\
\hline 513 & $\begin{array}{l}\text { Marazita ML, Murray JC, Lidral AC, Arcos-Burgos M, Cooper ME, Goldstein T, et al. Meta-analysis of } 13 \text { genome scans reveals multiple cleft lip/palate } \\
\text { genes with novel loci on 9q21 and 2q32-35. American journal of human genetics. 2004;75(2):161-73. }\end{array}$ & Non-orthodontic subject \\
\hline 514 & $\begin{array}{l}\text { Mardini HE, Schwartz DA. Treatment of perianal fistula and abscess: Crohn's and non-Crohn's. Current Treatment Options in Gastroenterology. } \\
2007 ; 10(3): 211-20 \text {. }\end{array}$ & Non-orthodontic subject \\
\hline 515 & $\begin{array}{l}\text { Martin-Cabezas R, Seelam N, Petit C, Agossa K, Gaertner S, Tenenbaum H, et al. Association between periodontitis and arterial hypertension: A } \\
\text { systematic review and meta-analysis. American Heart Journal. 2016;180:98-112. }\end{array}$ & Non-orthodontic subject \\
\hline 516 & $\begin{array}{l}\text { Martínez-Frías ML, Martín Bermejo M, Ayala Garcés A, Pardo Romero M, Bermejo Sánchez E, Urioste Azcorra M. The Hay-Wells syndrome, its incidence } \\
\text { in Spain and a review of the literature. Anales españoles de pediatría. 1996;45(1):101-4. }\end{array}$ & Non-orthodontic subject \\
\hline 517 & $\begin{array}{l}\text { Martins E, Silva JC, Pires CA, Ponces-Ramalhao MJ, Lopes JD. Coronal joint spaces of the Temporomandibular joint: Systematic review and meta- } \\
\text { analysis. Journal of clinical and experimental dentistry. 2015;7(3):e435-40. }\end{array}$ & Non-orthodontic subject \\
\hline 518 & $\begin{array}{l}\text { Matalon S, Schechtman S, Goldzweig G, Ornoy A. The teratogenic effect of carbamazepine: a meta-analysis of } 1255 \text { exposures. Reproductive toxicology } \\
\text { (Elmsford, NY). 2002;16(1):9-17. }\end{array}$ & Non-orthodontic subject \\
\hline 519 & $\begin{array}{l}\text { Matusiewicz H. Potential release of in vivo trace metals from metallic medical implants in the human body: From ions to nanoparticles - A systematic } \\
\text { analytical review. Acta Biomaterialia. } 2014 ; 10(6): 2379-403 \text {. }\end{array}$ & Non-orthodontic subject \\
\hline 520 & $\begin{array}{l}\text { McCallum I, King PM, Bruce J. Healing by primary versus secondary intention after surgical treatment for pilonidal sinus. Cochrane Database Syst Rev } \\
2007(4): C d 006213 \text {. }\end{array}$ & Non-orthodontic subject \\
\hline 521 & $\begin{array}{l}\text { McDonald S, Langton HCD, Nunez DA. Grommets (ventilation tubes) for recurrent acute otitis media in children. Cochrane Database of Systematic } \\
\text { Reviews. 2008; (4). Available from: http://onlinelibrary.wiley.com/doi/10.1002/14651858.CD004741.pub2/abstract }\end{array}$ & Non-orthodontic subject \\
\hline 522 & McKeigue PM, Lamm SH, Linn S, Kutcher JS. Bendectin and birth defects: I. A meta-analysis of the epidemiologic studies. Teratology. 1994;50(1):27-37. & Non-orthodontic subject \\
\hline 523 & Mealey BL, Oates TW. Diabetes mellitus and periodontal diseases. Journal of periodontology. 2006;77(8):1289-303. & Non-orthodontic subject \\
\hline 524 & $\begin{array}{l}\text { Medici M, van der Deure WM, Verbiest M, Vermeulen SH, Hansen PS, Kiemeney LA, et al. A large-scale association analysis of } 68 \text { thyroid hormone } \\
\text { pathway genes with serum TSH and FT4 levels. European Journal of Endocrinology. 2011;164(5):781-8. }\end{array}$ & Non-orthodontic subject \\
\hline 525 & $\begin{array}{l}\text { Menchero-Cantalejo E, Barona-Dorado C, Cantero-Álvarez M, Fernández-Cáliz F, Martínez-González JM. Meta-analysis on the survival of short implants. } \\
\text { Medicina oral, patologia oral y cirugia bucal. 2011;16(4):e546-e51. }\end{array}$ & Non-orthodontic subject \\
\hline 526 & $\begin{array}{l}\text { Mendelson ZS, Husain Q, Elmoursi S, Svider PF, Eloy JA, Liu JK. Rathke's cleft cyst recurrence after transsphenoidal surgery: a meta-analysis of } 1151 \\
\text { cases. J Clin Neurosci } 2014 ; 21(3): 378-85 \text {. }\end{array}$ & Non-orthodontic subject \\
\hline 527 & $\begin{array}{l}\text { Mendoza Hernández JL, Taxonera C, Lana R, Alba C, García-Paredes J, Díaz-Rubio M. Diagnostic and treatment recommendations on perianal Crohn's } \\
\text { disease. Revista Espanola de Enfermedades Digestivas. 2005;97(1):46-56. }\end{array}$ & Non-orthodontic subject \\
\hline 528 & $\begin{array}{l}\text { Meurman JH, Sanz M, Janket SJ. Oral health, atherosclerosis, and cardiovascular disease. Critical Reviews in Oral Biology and Medicine. } \\
2004 ; 15(6): 403-13 .\end{array}$ & Non-orthodontic subject \\
\hline 529 & $\begin{array}{l}\text { Mijiti A, Ling W, Guli, Moming A. Association of single-nucleotide polymorphisms in the IRF6 gene with non-syndromic cleft lip with or without cleft palate } \\
\text { in the Xinjiang Uyghur population. British Journal of Oral and Maxillofacial Surgery. } 2015 ; 53(3): 268-74 \text {. }\end{array}$ & Non-orthodontic subject \\
\hline 530 & $\begin{array}{l}\text { Miki T, Reo T, Tohru K, Joseph B, Gideon K, Elizabeth U, et al. Risks of congenital malformations in offspring exposed to val proic acid in utero: } \\
\text { Emergence of the signals over the last } 30 \text { years. Journal of Population Therapeutics and Clinical Pharmacology. 2014;21(2):e277. }\end{array}$ & Non-orthodontic subject \\
\hline 531 & $\begin{array}{l}\text { Mikulewicz M, Chojnacka K, Gedrange T, Gorecki H. Reference values of elements in human hair: a systematic review. Environmental toxicology and } \\
\text { pharmacology. 2013;36(3):1077-86. }\end{array}$ & Non-orthodontic subject \\
\hline 532 & $\begin{array}{l}\text { Milinkovic I, Cordaro L. Are there specific indications for the different alveolar bone augmentation procedures for implant placement? A systematic review. } \\
\text { International journal of oral and maxillofacial surgery. } 2014 ; 43(5): 606-25 \text {. }\end{array}$ & Non-orthodontic subject \\
\hline 533 & Miller SA. Efficiently Accessing the Evidence for Dental Practitioners. Journal of Evidence-Based Dental Practice. 2009;9(3):113-21. & Non-orthodontic subject \\
\hline 534 & Minckler D, Vedula SS, Li T, Mathew M. Ayyala R, Francis B. Aqueous shunts for glaucoma. Cochrane Database of Systematic Reviews. 2006; (2). & Non-orthodontic subject \\
\hline 535 & $\begin{array}{l}\text { Mitchell LE, Beaty TH, Lidral AC, Munger RG, Murray JC, Saal HM, et al. Guidelines for the design and analysis of studies on nonsyndromic cleft lip and } \\
\text { cleft palate in humans: summary report from a Workshop of the International Consortium for Oral Clefts Genetics. Cleft Palate Craniofac J 2002;39(1):93- } \\
100 \text {. }\end{array}$ & Non-orthodontic subject \\
\hline 536 & $\begin{array}{l}\text { Mitchell LE. Transforming growth factor alpha locus and nonsyndromic cleft lip with or without cleft palate: a reappraisal. Genetic epidemiology. } \\
\text { 1997;14(3):231-40. }\end{array}$ & Non-orthodontic subject \\
\hline 537 & $\begin{array}{l}\text { Mocellin S, Verdi D, Pooley KA, Landi MT, Egan KM, Baird DM, et al. Telomerase reverse transcriptase locus polymorphisms and cancer risk: a field } \\
\text { synopsis and meta-analysis. Journal of the National Cancer Institute. 2012;104(11):840-54. }\end{array}$ & Non-orthodontic subject \\
\hline 538 & Mok CC. Therapeutic Options for Resistant Lupus Nephritis. Seminars in Arthritis and Rheumatism. 2006;36(2):71-81. & Non-orthodontic subject \\
\hline 539 & $\begin{array}{l}\text { Mok KY, Sheerin U, Simón-Sánchez J, Salaka A, Chester L, Escott-Price V, et al. Deletions at 22q11.2 in idiopathic Parkinson's disease: A combined } \\
\text { analysis of genome-wide association data. The Lancet Neurology. 2016;15(6):585-96. }\end{array}$ & Non-orthodontic subject \\
\hline 540 & $\begin{array}{l}\text { Molina-Solana R, Yanez-Vico RM, Iglesias-Linares A, Mendoza-Mendoza A, Solano-Reina E. Current concepts on the effect of environmental factors on } \\
\text { cleft lip and palate. International journal of oral and maxillofacial surgery. } 2013 ; 42(2): 177-84 \text {. }\end{array}$ & Non-orthodontic subject \\
\hline 541 & $\begin{array}{l}\text { Moraschini V, Porto Barboza E. Immediate versus conventional loaded single implants in the posterior mandible: A meta-analysis of randomized controlled } \\
\text { trials. International journal of oral and maxillofacial surgery. } 2016 ; 45(1): 85-92 \text {. }\end{array}$ & Non-orthodontic subject \\
\hline 542 & $\begin{array}{l}\text { Morency AM, Bujold E. The Effect of Second-Trimester Antibiotic Therapy on the Rate of Preterm Birth. Journal of Obstetrics and Gynaecology Canada. } \\
\text { 2007;29(1):35-44. }\end{array}$ & Non-orthodontic subject \\
\hline 543 & $\begin{array}{l}\text { Morimoto S, Rebello de Sampaio FB, Braga MM, Sesma N, Ozcan M. Survival Rate of Resin and Ceramic Inlays, Onlays, and Overlays: A Systematic } \\
\text { Review and Meta-analysis. Journal of dental research. 2016;95(9):985-94. }\end{array}$ & Non-orthodontic subject \\
\hline 544 & Morton S, Thangaratinam S. Statins in pregnancy. Current Opinion in Obstetrics and Gynecology. 2013;25(6):433-40. & Non-orthodontic subject \\
\hline 545 & $\begin{array}{l}\text { Mosler AB, Agricola R, Weir A, Holmich P, Crossley KM. Which factors differentiate athletes with hip/groin pain from those without? A systematic review } \\
\text { with meta-analysis. British journal of sports medicine. } 2015 ; 49(12): 810 \text {. }\end{array}$ & Non-orthodontic subject \\
\hline 546 & Mulcahy MF, Benson lii AB. Bevacizumab in the treatment of colorectal cancer. Expert Opinion on Biological Therapy. 2005;5(7):997-1005. & Non-orthodontic subject \\
\hline 547 & $\begin{array}{l}\text { Müller HP. Does chronic periodontitis play a role in the pathogenesis of cardiovascular and cerebrovascular diseases? Gesundheitswesen. 2002;64(2):89- } \\
98 .\end{array}$ & Non-orthodontic subject \\
\hline 548 & $\begin{array}{l}\text { Munabi N, Swanson J, Auslander A, Sanchez P, Davidson Ward SL, Magee W. Incidence of congenital heart disease in nonsyndromic cleft lip and/or } \\
\text { palate: A systematic review of the literature. Cleft Palate-Craniofacial Journal. } 2016 ; 53(4): e 128 .\end{array}$ & Non-orthodontic subject \\
\hline 549 & $\begin{array}{l}\text { Murphy GR, Glass GE, Jain A. The Efficacy and Safety of Tranexamic Acid in Cranio-Maxillofacial and Plastic Surgery. The Journal of craniofacial } \\
\text { surgery. } 2016 ; 27(2): 374-9 \text {. }\end{array}$ & Non-orthodontic subject \\
\hline 550 & $\begin{array}{l}\text { Murphy VE, Schatz M. Asthma in pregnancy: a hit for two. European respiratory review : an official journal of the European Respiratory Society. } \\
2014 ; 23(131): 64-8 \text {. }\end{array}$ & Non-orthodontic subject \\
\hline 551 & $\begin{array}{l}\text { Murphy VE, Wang G, Namazy JA, Powell H, Gibson PG, Chambers C, et al. The risk of congenital malformations, perinatal mortality and neonatal } \\
\text { hospitalisation among pregnant women with asthma: a systematic review and meta-analysis. BJOG : an international journal of obstetrics and } \\
\text { gynaecology. 2013;120(7):812-22. }\end{array}$ & Non-orthodontic subject \\
\hline 552 & $\begin{array}{l}\text { Namazy JA, Murphy VE, Powell H, Gibson PG, Chambers CD, Schatz M. Congenital anomalies in asthmatic women using corticosteroids during } \\
\text { pregnancy: A meta analysis from published data. Birth Defects Research Part A - Clinical and Molecular Teratology. 2010;88(5):364. }\end{array}$ & Non-orthodontic subject \\
\hline 553 & $\begin{array}{l}\text { Nascimento GG, Leite FRM, Conceição DA, Ferrúa CP, Singh A, Demarco FF. Is there a relationship between obesity and tooth loss and edentulism? A } \\
\text { systematic review and meta-analysis. Obesity Reviews. } 2016 ; 17(7): 587-98 \text {. }\end{array}$ & Non-orthodontic subject \\
\hline 554 & $\begin{array}{l}\text { Neelapu BC, Kharbanda OP, Sardana HK, Balachandran R, Sardana V, Kapoor P, et al. Craniofacial and upper airway morphology in adult obstructive } \\
\text { sleep apnea patients: A systematic review and meta-analysis of cephalometric studies. Sleep medicine reviews. } 2016 \text {. }\end{array}$ & Non-orthodontic subject \\
\hline 555 & $\begin{array}{l}\mathrm{Ni} \mathrm{Y,} \mathrm{Li} \mathrm{H,} \mathrm{Zhang} \mathrm{Y,} \mathrm{Zhang} \mathrm{H,} \mathrm{Pan} \mathrm{Y,} \mathrm{Ma} \mathrm{J,} \mathrm{et} \mathrm{al.} \mathrm{Association} \mathrm{of} \mathrm{IL-6} \mathrm{G-174C} \mathrm{polymorphism} \mathrm{with} \mathrm{bone} \mathrm{mineral} \mathrm{density.} \mathrm{Journal} \mathrm{of} \mathrm{Bone} \mathrm{and} \mathrm{Mineral} \\
\text { Metabolism. 2014;32(2):167-73. }\end{array}$ & Non-orthodontic subject \\
\hline 556 & $\begin{array}{l}\text { Nickl-Jockschat T, Janouschek H, Eickhoff SB, Eickhoff CR. No meta-analytic evidence for an association between COMT VAL158MET genotype on brain } \\
\text { activation during working memory tasks. Biological Psychiatry. } 2015 ; 77(9): 404 \mathrm{~S} \text {. }\end{array}$ & Non-orthodontic subject \\
\hline 557 & $\begin{array}{l}\text { Nicoletti D, Appel LD, Neto PS, Guimaraes GW, Zhang LJ. Maternal smoking during pregnancy and birth defects in children: a systematic review with } \\
\text { meta-analysis. Cadernos De Saude Publica. 2014;30(12):2491-529. }\end{array}$ & Non-orthodontic subject \\
\hline 558 & $\begin{array}{l}\text { Nieuwenhuijsen MJ, Martinez D, Grellier J, Bennett J, Best N, Iszatt N, et al. Chlorination disinfection by-products in drinking water and congenital } \\
\text { anomalies: Review and meta-analyses. Ciencia e Saude Coletiva. 2010;15(SUPPL. 2):3109-23. }\end{array}$ & Non-orthodontic subject \\
\hline
\end{tabular}




\begin{tabular}{|c|c|c|}
\hline 559 & $\begin{array}{l}\text { Nieuwenhuijsen MJ, Martinez D, Grellier J, Bennett J, Best N, Iszatt N, et al. Chlorination disinfection by-products in drinking water and congenital } \\
\text { anomalies: review and meta-analyses. Environmental health perspectives. 2009;117(10):1486-93. }\end{array}$ & Non-orthodontic subject \\
\hline 560 & Nishi SE, Basri R, Alam MK. Uses of electromyography in dentistry: An overview with meta-analysis. European journal of dentistry. 2016;10(3):419-25. & Non-orthodontic subject \\
\hline 561 & $\begin{array}{l}\text { Noble S, Markham A. Cyclosporin: A review of the pharmacokinetic properties, clinical efficacy and tolerability of a microemulsion-based formulation } \\
\text { (Neoral( }) \text {. Drugs. 1995;50(5):924-41. }\end{array}$ & Non-orthodontic subject \\
\hline 562 & $\begin{array}{l}\text { Nogueira RJN, Lima AES, Ribeiro AF, Gil-Da-Silva-Lopes VL. A proposal of an algorithm for pre-surgical nutritional intervention in orofacial clefts babies. } \\
\text { Clinical Nutrition, Supplement. 2012;7(1):137. }\end{array}$ & Non-orthodontic subject \\
\hline 563 & $\begin{array}{l}\text { Norman A, Persson M, Stock N, Rumsey N, Sandy J, Waylen A, et al. The effectiveness of psychosocial intervention for individuals with cleft lip and/or } \\
\text { palate. Database of Abstracts of Reviews of Effects. } 2014 ;(2):[\text { epub p.]. }\end{array}$ & Non-orthodontic subject \\
\hline 564 & $\begin{array}{l}\text { Norman G, Dumville JC, Mohapatra DP, Owens GL, Crosbie EJ. Antibiotics and antiseptics for surgical wounds healing by secondary intention. Cochrane } \\
\text { Database of Systematic Reviews. 2016; (3). Available from: http://onlinelibrary.wiley.com/doi/10.1002/14651858.CD011712.pub2/abstract }\end{array}$ & Non-orthodontic subject \\
\hline 565 & O'Connor A, Swick AG. Interface between pharmacotherapy and genes in human obesity. Human Heredity. 2013;75(2-4):116-26. & Non-orthodontic subject \\
\hline 566 & Odaka M. Chronic inflammatory demyelinating polyneuropathy: A treatment protocol proposal. Expert Review of Neurotherapeutics. 2006;6(3):365-79. & Non-orthodontic subject \\
\hline 567 & Ohbayashi H. Current synthetic inhibitors of human neutrophil elastase in 2005. Expert Opinion on Therapeutic Patents. 2005;15(7):759-71. & Non-orthodontic subject \\
\hline 568 & $\begin{array}{l}\text { Oliveira CA, Tannure PN, de Souza IP, Maia LC, Portela MB, Castro GF. Is dental caries experience increased in HIV-infected children and adolescents? } \\
\text { A meta-analysis. Acta odontologica Scandinavica. 2015;73(7):481-7. }\end{array}$ & Non-orthodontic subject \\
\hline 569 & $\begin{array}{l}\text { Olsen JJ, Skov J, Ingerslev J, Thorn JJ, Pinholt EM. Prevention of Bleeding in Orthognathic Surgery--A Systematic Review and Meta-Analysis of } \\
\text { Randomized Controlled Trials. J Oral Maxillofac Surg. 2016;74(1):139-50. }\end{array}$ & Non-orthodontic subject \\
\hline 570 & $\begin{array}{l}\text { Oomens MA, Verlinden CR, Goey Y, Forouzanfar T. Prescribing antibiotic prophylaxis in orthognathic surgery: a systematic review. International journal of } \\
\text { oral and maxillofacial surgery. } 2014 ; 43(6): 725-31 \text {. }\end{array}$ & Non-orthodontic subject \\
\hline 571 & $\begin{array}{l}\text { Oren D, Nulman I, Makhija M, Ito S, Koren G. Using corticosteroids during pregnancy. Are topical, inhaled, or systemic agents associated with risk? } \\
\text { Canadian family physician Medecin de famille canadien. } 2004 ; 50: 1083-5 \text {. }\end{array}$ & Non-orthodontic subject \\
\hline 572 & $\begin{array}{l}\text { Orlandi M, Suvan J, Petrie A, Donos N, Masi S, Hingorani A, et al. Association between periodontal disease and its treatment, flow-mediated dilatation and } \\
\text { carotid intima-media thickness: A systematic review and meta-analysis. Atherosclerosis. } 2014 ; 236(1): 39 \mathrm{e} 46 \text {. }\end{array}$ & Non-orthodontic subject \\
\hline 573 & Østensen M, Förger F. How safe are anti-rheumatic drugs during pregnancy? Current Opinion in Pharmacology. 2013;13(3):470-5. & Non-orthodontic subject \\
\hline 574 & Pack AM. Therapy Insight: Clinical management of pregnant women with epilepsy. Nature Clinical Practice Neurology. 2006;2(4):190-200. & Non-orthodontic subject \\
\hline 575 & $\begin{array}{l}\text { Pagani C, Feitosa FA, Esteves SRMS, Miranda GMd, Antunes DP, Carvalho RFd. Dentinal Hypersensitivity: pre-hybridization as an alternative treatment. } \\
\text { Braz dent sci. } 2013 ; 16(3): 18-25 \text {. }\end{array}$ & Non-orthodontic subject \\
\hline 576 & Palacios C, Joshipura KJ, Willett WC. Nutrition and health: Guidelines for dental practitioners. Oral Diseases. 2009;15(6):369-81. & Non-orthodontic subject \\
\hline 577 & $\begin{array}{l}\text { Palaska PK, Antonarakis GS. Prevalence and patterns of permanent tooth agenesis in individuals with Down syndrome: a meta-analysis. European } \\
\text { journal of oral sciences. 2016;124(4):317-28. }\end{array}$ & Non-orthodontic subject \\
\hline 578 & $\begin{array}{l}\text { Palmer S, Ruospo M, Pellegrini F, Strippoli GFM. Oral disease in people with chronic kidney disease: A systematic reviewand meta-analysis of cohort } \\
\text { studies. Nephrology Dialysis Transplantation. 2013;28:i265-i6. }\end{array}$ & Non-orthodontic subject \\
\hline 579 & $\begin{array}{l}\text { Pan X, Wang P, Yin X, Liu X, Li D, Li X, et al. Association between Maternal MTHFR Polymorphisms and Nonsyndromic Cleft Lip with or without Cleft } \\
\text { Palate in Offspring, A Meta-Analysis Based on } 15 \text { Case-Control Studies. International journal of fertility \& sterility. 2015;8(4):463-80. }\end{array}$ & Non-orthodontic subject \\
\hline 580 & $\begin{array}{l}\text { Pan Y, Han Y, Zhang H, Zhou L, Li D, Cai Q, et al. Association and cumulative effects of GWAS-identified genetic variants for nonsyndromic orofacial } \\
\text { clefts in a Chinese population. Environmental and molecular mutagenesis. 2013;54(4):261-7. }\end{array}$ & Non-orthodontic subject \\
\hline 581 & $\begin{array}{l}\text { Pan Y, Zhang W, Ma J, Du Y, Li D, Cai Q, et al. Erratum: Infants' MTHFR polymorphisms and nonsyndromic orofacial clefts susceptibility: A meta-analysis } \\
\text { based on } 17 \text { case-control studies (Obstetrical and Gynecological Survey (2013) 68:1 (12-13)). Obstetrical and Gynecological Survey. 2013;68(2):157-9. }\end{array}$ & Non-orthodontic subject \\
\hline 582 & $\begin{array}{l}\text { Pan Y, Zhang W, Ma J, Du Y, Li D, Cai Q, et al. Infants' MTHFR polymorphisms and nonsyndromic orofacial clefts susceptibility: a meta-analysis based on } \\
17 \text { case-control studies. American journal of medical genetics Part A. 2012;158a(9):2162-9. }\end{array}$ & Non-orthodontic subject \\
\hline 583 & $\begin{array}{l}\text { Papageorgiou PN, Deschner J, Papageorgiou SN. Effectiveness and Adverse Effects of Deep Brain Stimulation: Umbrella Review of Meta-Analyses. } \\
\text { Journal of neurological surgery Part A, Central European neurosurgery. 2016. }\end{array}$ & Non-orthodontic subject \\
\hline 584 & $\begin{array}{l}\text { Papageorgiou SN, Papageorgiou PN, Deschner J, Gotz W. Comparative effectiveness of natural and synthetic bone grafts in oral and maxillofacial } \\
\text { surgery prior to insertion of dental implants: Systematic review and network meta-analysis of parallel and cluster randomized controlled trials. Journal of } \\
\text { dentistry. } 2016 ; 48: 1-8 \text {. }\end{array}$ & Non-orthodontic subject \\
\hline 585 & $\begin{array}{l}\text { Papageorgiou SN, Reichert C, Jager A, Deschner J. Effect of overweight/obesity on response to periodontal treatment: systematic review and a meta- } \\
\text { analysis. Journal of clinical periodontology. } 2015 ; 42(3): 247-61 \text {. }\end{array}$ & Non-orthodontic subject \\
\hline 586 & $\begin{array}{l}\text { Parekh S, Gardener C, Ashley PF, Walsh T. Intraoperative local anaesthesia for reduction of postoperative pain following general anaesthesia for dental } \\
\text { treatment in children and adolescents. Cochrane Database Syst Rev 2014(12):Cd009742. }\end{array}$ & Non-orthodontic subject \\
\hline 587 & $\begin{array}{l}\text { Park JH, Yamaguchi T, Watanabe C, Kawaguchi A, Haneji K, Takeda M, et al. Effects of an Asian-specific nonsynonymous EDAR variant on multiple } \\
\text { dental traits. Journal of human genetics. 2012;57(8):508-14. }\end{array}$ & Non-orthodontic subject \\
\hline 588 & $\begin{array}{l}\text { Park-Wyllie L, Mazzotta P, Pastuszak A, Moretti ME, Beique L, Hunnisett L, et al. Birth defects after maternal exposure to corticosteroids: prospective } \\
\text { cohort study and meta-analysis of epidemiological studies. Teratology. 2000;62(6):385-92. }\end{array}$ & Non-orthodontic subject \\
\hline 589 & $\begin{array}{l}\text { Parnham MJ, Haber VE, Giamarellos-Bourboulis EJ, Perletti G, Verleden GM, Vos R. Azithromycin: Mechanisms of action and their relevance for clinical } \\
\text { applications. Pharmacology and Therapeutics. 2014;143(2):225-45. }\end{array}$ & Non-orthodontic subject \\
\hline 590 & $\begin{array}{l}\text { Patton LL, Shugars DA, Bonito AJ. A systematic review of complication risks for HIV-positive patients undergoing invasive dental procedures. Journal of } \\
\text { the American Dental Association (1939). 2002;133(2):195-203. }\end{array}$ & Non-orthodontic subject \\
\hline 591 & $\begin{array}{l}\text { Paul JE, Ling E, Lalonde C, Thabane L. Deliberate hypotension in orthopedic surgery reduces blood loss and transfusion requirements: a meta-analysis of } \\
\text { randomized controlled trials. Canadian journal of anaesthesia = Journal canadien d'anesthesie. } 2007 ; 54(10): 799-810 .\end{array}$ & Non-orthodontic subject \\
\hline 592 & $\begin{array}{l}\text { Paumgartten FJ. Developmental risks associated with use of psychoactive drugs during pregnancy are largely unknown. Revista Brasileira de Psiquiatria. } \\
2014 ; 36(4): 359 .\end{array}$ & Non-orthodontic subject \\
\hline 593 & Pavia M, Nobile CGA, Angelillo IF. Meta-analysis of local tetracycline in treating chronic periodontitis. Journal of periodontology. 2003;74(6):916-32. & Non-orthodontic subject \\
\hline 594 & $\begin{array}{l}\text { Peleg AY, Weerarathna T, McCarthy JS, Davis TME. Common infections in diabetes: Pathogenesis, management and relationship to glycaemic control. } \\
\text { Diabetes/Metabolism Research and Reviews. 2007;23(1):3-13. }\end{array}$ & Non-orthodontic subject \\
\hline 595 & $\begin{array}{l}\text { Peltz ID. Evidence lacking to determine whether preoperative analgesic use reduces post dental treatment pain for children. Evidence-based dentistry. } \\
\text { 2012;13(4):104. }\end{array}$ & Non-orthodontic subject \\
\hline 596 & $\begin{array}{l}\text { Peng L, Bu Z, Zhou Y, Ye X, Liu J, Zhao Q. Hemorrhagic events in cancer patients treated with aflibercept: a meta-analysis. Tumor Biology. } \\
\text { 2014;35(9):9419-27. }\end{array}$ & Non-orthodontic subject \\
\hline 597 & $\begin{array}{l}\text { Penninga L, Møller CH, Gustafsson F, Steinbrüchel DA, Gluud C. Tacrolimus versus cyclosporine as primary immunosuppression after heart } \\
\text { transplantation: Systematic review with meta-analyses and trial sequential analyses of randomised trials. European Journal of Clinical Pharmacology. } \\
\text { 2010;66(12):1177-87. }\end{array}$ & Non-orthodontic subject \\
\hline 598 & $\begin{array}{l}\text { Perinetti G, Türp JC, Primožič J, Di Lenarda R, Contardo L. Associations between the masticatory system and muscle activity of other body districts. A } \\
\text { meta-analysis of surface electromyography studies. Journal of Electromyography and Kinesiology. } 2011 ; 21(6): 877-84 \text {. }\end{array}$ & Non-orthodontic subject \\
\hline 599 & Phillips MF, Quinlivan R. Calcium antagonists for Duchenne muscular dystrophy. Cochrane Database of Systematic Reviews. 2008(4). & Non-orthodontic subject \\
\hline 600 & $\begin{array}{l}\text { Pillas D, Hoggart CJ, Evans DM, O'Reilly PF, Sipila K, Lahdesmaki R, et al. Genome-wide association study reveals multiple loci associated with primary } \\
\text { tooth development during infancy. PLoS genetics. 2010;6(2):e1000856. }\end{array}$ & Non-orthodontic subject \\
\hline 601 & $\begin{array}{l}\text { Pinquart M, Shen Y. Anxiety in children and adolescents with chronic physical illnesses: A meta-analysis. Acta Paediatrica, International Journal of } \\
\text { Paediatrics. 2011;100(8):1069-76. }\end{array}$ & Non-orthodontic subject \\
\hline 602 & $\begin{array}{l}\text { Pinquart M, Shen Y. Depressive symptoms in children and adolescents with chronic physical illness: an updated meta-analysis. Journal of pediatric } \\
\text { psychology. 2011;36(4):375-84. }\end{array}$ & Non-orthodontic subject \\
\hline 603 & $\begin{array}{l}\text { Pires PS, Medeiros LR, Simões PW, Silva NC, Silva BR, Silva FR, et al. Periodontal therapy and risk of preterm birth: A systematic review and meta- } \\
\text { analysis. International Journal of Gynecology and Obstetrics. 2012;119:S747. }\end{array}$ & Non-orthodontic subject \\
\hline 604 & Pitten FA, Kramer A. Efficacy of cetylpyridinium chloride used as oropharyngeal antiseptic. Arzneimittel-Forschung/Drug Research. 2001;51(7):588-95. & Non-orthodontic subject \\
\hline 605 & $\begin{array}{l}\text { Poklepovic T, Worthington HV, Johnson TM, Sambunjak D, Imai P, Clarkson JE, et al. Interdental brushing for the prevention and control of periodontal } \\
\text { diseases and dental caries in adults. Cochrane Database of Systematic Reviews. 2013; (12). }\end{array}$ & Non-orthodontic subject \\
\hline 606 & $\begin{array}{l}\text { Polyzos NP, Polyzos IP, Mauri D, Tzioras S, Tsappi M, Cortinovis I, et al. Effect of periodontal disease treatment during pregnancy on preterm birth } \\
\text { incidence: a metaanalysis of randomized trials. American Journal of Obstetrics and Gynecology. } 2009 ; 200(3): 225-32 \text {. }\end{array}$ & Non-orthodontic subject \\
\hline 607 & $\begin{array}{l}\text { Poquet N, Lin C-WC, Heymans MW, van TMW, Esmail R, Koes BW, et al. Back schools for acute and subacute non-specific low-back pain. Cochrane } \\
\text { Database of Systematic Reviews. 2016; (4). Available from: http://onlinelibrary.wiley.com/doi/10.1002/14651858.CD008325.pub2/abstract }\end{array}$ & Non-orthodontic subject \\
\hline 608 & $\begin{array}{l}\text { Porcu E, Medici M, Pistis G, Volpato CB, Wilson SG, Cappola AR, et al. A Meta-Analysis of Thyroid-Related Traits Reveals Novel Loci and Gender- } \\
\text { Specific Differences in the Regulation of Thyroid Function. PLoS genetics. 2013;9(2). }\end{array}$ & Non-orthodontic subject \\
\hline
\end{tabular}




\begin{tabular}{|c|c|c|}
\hline 609 & $\begin{array}{l}\text { Prica A, Sholzberg M, Buckstein R. Thrombopoietin (TPO)-receptor agonists in myelodysplastic syndromes (MDS): A systematic review and meta- } \\
\text { analysis. Blood. 2013;122(21). }\end{array}$ & Non-orthodontic subject \\
\hline 610 & $\begin{array}{l}\text { Proietti E, Röösli M, Frey U, Latzin P. Air pollution during pregnancy and neonatal outcome: A review. Journal of Aerosol Medicine and Pulmonary Drug } \\
\text { Delivery. 2013;26(1):9-23. }\end{array}$ & Non-orthodontic subject \\
\hline 611 & $\begin{array}{l}\text { Pushparaj PN, Aarthi JJ, Biswas S, Jayapal M, Narasimhan K, Al-Qahtani MH. Decrypting the genomic signatures associated with experimental colitis in } \\
\text { mice. Immunology. 2012;137:26-7. }\end{array}$ & Non-orthodontic subject \\
\hline 612 & $\begin{array}{l}\text { Putku M, Kepp K, Org E, Sober S, Comas D, Viigimaa M, et al. Novel polymorphic AluYb8 insertion in the WNK1 gene is associated with blood pressure } \\
\text { variation in Europeans. Human mutation. } 2011 ; 32(7): 806-14 \text {. }\end{array}$ & Non-orthodontic subject \\
\hline 613 & $\begin{array}{l}\text { Qu HC, Zhang W, Liu YL, Wang P. Association between polymorphism of beta3-adrenoceptor gene and overactive bladder: a meta-analysis. Genetics } \\
\text { and molecular research : GMR. 2015;14(1):2495-501. }\end{array}$ & Non-orthodontic subject \\
\hline 614 & $\begin{array}{l}\text { Qu HC, Zhang W, Yan S, Liu YL, Wang P. Urinary nerve growth factor could be a biomarker for interstitial cystitis/painful bladder syndrome: a meta- } \\
\text { analysis. PloS one. 2014;9(9):e106321. }\end{array}$ & Non-orthodontic subject \\
\hline 615 & Que KH, Guo B. Evidence-based practice of pit and fissure sealants. Chinese Journal of Evidence-Based Medicine. 2006;6(2):146-9. & Non-orthodontic subject \\
\hline 616 & $\begin{array}{l}\text { Queiroz Herkrath AP, Herkrath FJ, Rebelo MA, Vettore MV. Measurement of health-related and oral health-related quality of life among individuals with } \\
\text { nonsyndromic orofacial clefts: a systematic review and meta-analysis. Cleft Palate Craniofac J } 2015 ; 52(2): 157-72 \text {. }\end{array}$ & Non-orthodontic subject \\
\hline 617 & Quinlan JD, Hill DA. Nausea and vomiting of pregnancy. American Family Physician. 2003;68(1):121-8. & Non-orthodontic subject \\
\hline 618 & $\begin{array}{l}\text { Rahimi R, Nikfar S, Rezaie A, Abdollahi M. Comparison of mesalazine and balsalazide in induction and maintenance of remission in patients with } \\
\text { ulcerative colitis: A meta-analysis. Digestive Diseases and Sciences. 2009;54(4):712-21. }\end{array}$ & Non-orthodontic subject \\
\hline 619 & $\begin{array}{l}\text { Rakhshan V, Rakhshan A. Systematic review and meta-analysis of congenitally missing permanent dentition: Sex dimorphism, occurrence patterns, } \\
\text { associated factors and biasing factors. International orthodontics. } 2016 ; 14(3): 273-94 \text {. }\end{array}$ & Non-orthodontic subject \\
\hline 620 & $\begin{array}{l}\text { Rakhshan V, Rakhshan } \mathrm{H} \text {. Meta-analysis and systematic review of the number of non-syndromic congenitally missing permanent teeth per affected } \\
\text { individual and its influencing factors. Eur J Orthod } 2016 ; 38(2): 170-7 \text {. }\end{array}$ & Non-orthodontic subject \\
\hline 621 & $\begin{array}{l}\text { Rakhshan V. Meta-analysis and systematic review of factors biasing the observed prevalence of congenitally missing teeth in permanent dentition } \\
\text { excluding third molars. Prog Orthod } 2013 ; 14: 33 \text {. }\end{array}$ & Non-orthodontic subject \\
\hline 622 & $\begin{array}{l}\text { Rakhshan V. Meta-Analysis of Observational Studies on the Most Commonly Missing Permanent Dentition (Excluding the Third Molars) in NonSyndromic } \\
\text { Dental Patients or Randomly-Selected Subjects, and the Factors Affecting the Observed Rates. Journal of Clinical Pediatric Dentistry. 2015;39(3):199- } \\
208 .\end{array}$ & Non-orthodontic subject \\
\hline 623 & $\begin{array}{l}\text { Rao A, Ahmed MK, Taub PJ, Mamoun JS. The Correlation between Maternal Exposure to Air Pollution and the Risk of Orofacial Clefts in Infants: a } \\
\text { Systematic Review and Meta-Analysis. Journal of oral \& maxillofacial research. } 2016 ; 7(1): \mathrm{e} 2 \text {. }\end{array}$ & Non-orthodontic subject \\
\hline 624 & $\begin{array}{l}\text { Ratz T, Dean LE, Atzeni F, Reeks C, Macfarlane GJ, Macfarlane TV. A possible link between ankylosing spondylitis and periodontitis: A systematic review } \\
\text { and meta-analysis. Rheumatology (United Kingdom). 2015;54(3):500-10. }\end{array}$ & Non-orthodontic subject \\
\hline 625 & $\begin{array}{l}\text { Reinisch W, Dejaco C, Knoflach P, Petritsch W, Vogelsang H, Tilg H. Immunosuppressive therapy for inflammatory bowel disease: Consensus by the } \\
\text { Austrian Working Group on IBD. Zeitschrift fur Gastroenterologie. 2004;42(9):1033-45. }\end{array}$ & Non-orthodontic subject \\
\hline 626 & $\begin{array}{l}\text { Reis A, Dourado Loguercio A, Schroeder M, Luque-Martinez I, Masterson D, Cople Maia L. Does the adhesive strategy influence the post-operative } \\
\text { sensitivity in adult patients with posterior resin composite restorations?: A systematic review and meta-analysis. Dental materials : official publication of the } \\
\text { Academy of Dental Materials. } 2015 ; 31(9): 1052-67 \text {. }\end{array}$ & Non-orthodontic subject \\
\hline 627 & $\begin{array}{l}\text { Renatus A, Herrmann J, Schönfelder A, Schwarzenberger F, Jentsch H. Clinical efficacy of azithromycin as an adjunctive therapy to non-surgical } \\
\text { periodontal treatment of periodontitis: A systematic review and meta-analysis. Journal of Clinical and Diagnostic Research. 2016;10(7):ZE01-ZE7. }\end{array}$ & Non-orthodontic subject \\
\hline 628 & $\begin{array}{l}\text { Renner TJ, Walitza S, Dempfle A, Eckert L, Romanos M, Gerlach M, et al. Allelic variants of SNAP25 in a family-based sample of ADHD. Journal of } \\
\text { Neural Transmission. 2008;115(2):317-21. }\end{array}$ & Non-orthodontic subject \\
\hline 629 & $\begin{array}{l}\text { Revuelta MV, van Kan JA, Kay J, Ten Have A. Extensive expansion of A1 family aspartic proteinases in fungi revealed by evolutionary analyses of } 107 \\
\text { complete eukaryotic proteomes. Genome biology and evolution. } 2014 ; 6(6): 1480-94 \text {. }\end{array}$ & Non-orthodontic subject \\
\hline 630 & Richardson C, Emery P. Clinical use of cyclosporin in rheumatoid arteritis. Drugs. 1995;50(SUPPL. 1):26-36. & Non-orthodontic subject \\
\hline 631 & $\begin{array}{l}\text { Roberts RM, Mathias JL, Wheaton P. Cognitive functioning in children and adults with nonsyndromal cleft lip and/or palate: a meta-analysis. Journal of } \\
\text { pediatric psychology. 2012;37(7):786-97. }\end{array}$ & Non-orthodontic subject \\
\hline 632 & $\begin{array}{l}\text { Robertson L, Wu O, Langhorne P, Twaddle S, Clark P, Lowe GDO, et al. Thrombophilia in pregnancy: A systematic review. British Journal of } \\
\text { Haematology. 2006;132(2):171-96. }\end{array}$ & Non-orthodontic subject \\
\hline 633 & $\begin{array}{l}\text { Rodríguez-Cabrera MA, Barona-Dorado C, Leco-Berrocal I, Gómez-Moreno G, Martínez-González JM. Extractions without eliminating anticoagulant } \\
\text { treatment: A literature review. Medicina oral, patologia oral y cirugia bucal. } 2011 ; 16(6): 00-4 \text {. }\end{array}$ & Non-orthodontic subject \\
\hline 634 & Romitti PA, Herring AM, Dennis LK, Wong-Gibbons DL. Meta-analysis: pesticides and orofacial clefts. Cleft Palate Craniofac J 2007;44(4):358-65. & Non-orthodontic subject \\
\hline 635 & $\begin{array}{l}\text { Rosado } \mathrm{P} \text {, Cheng H, Wu C, Wei F. Influence of diabetes mellitus on postoperative complications and failure in head and neck free flap reconstruction: a } \\
\text { systematic review and meta-analysis. Head and Neck. 2014; (2):[epub p.]. }\end{array}$ & Non-orthodontic subject \\
\hline 636 & $\begin{array}{l}\text { Ruan C, Long H, Sun H, He M, Yang K, Zhang H, et al. Endovascular coiling vs. surgical clipping for unruptured intracranial aneurysm: A meta-analysis. } \\
\text { British Journal of Neurosurgery. 2015;29(4):485-92. }\end{array}$ & Non-orthodontic subject \\
\hline 637 & $\begin{array}{l}\text { Ruf S, Klimas D, Honemann M, Jabir S. Genetic background of nonsyndromic oligodontia: a systematic review and meta-analysis. J Orofac Orthop } \\
\text { 2013;74(4):295-308. }\end{array}$ & Non-orthodontic subject \\
\hline 638 & Rufo PA, Bousvaros A. Current therapy of inflammatory bowel disease in children. Pediatric Drugs. 2006;8(5):279-302. & Non-orthodontic subject \\
\hline 639 & $\begin{array}{l}\text { Ruospo M, Palmer S, Vecchio M, Gargano L, Petruzzi M, De Benedictis M, et al. Oral disease in people with chronic kidney disease: Meta-analysis of } \\
\text { prevalence and association with clinical outcomes. Nephrology Dialysis Transplantation. 2012;27:ii394-ii5. }\end{array}$ & Non-orthodontic subject \\
\hline 640 & $\begin{array}{l}\text { Rushfeldt C, Soreide K. [Surgical treatment of pilonidal disease]. Tidsskrift for den Norske laegeforening : tidsskrift for praktisk medicin, ny raekke. } \\
\text { 2010;130(9):936-9. }\end{array}$ & Non-orthodontic subject \\
\hline 641 & Rutecki GW. Building bridges from primary care to dentistry. Consultant. 2007;47(4):354. & Non-orthodontic subject \\
\hline 642 & $\begin{array}{l}\text { Ruyssen-Witrand A, Constantin A, Cambon-Thomsen A, Thomsen M. New insights into the genetics of immune responses in rheumatoid arthritis. Tissue } \\
\text { Antigens. 2012;80(2):105-18. }\end{array}$ & Non-orthodontic subject \\
\hline 643 & $\begin{array}{l}\text { Sabbagh HJ, Hassan MH, Innes NP, Baik AA, Mossey PA. Parental consanguinity and nonsyndromic orofacial clefts in children: a systematic review and } \\
\text { meta-analyses. Cleft Palate Craniofac J 2014;51(5):501-13. }\end{array}$ & Non-orthodontic subject \\
\hline 644 & $\begin{array}{l}\text { Sabbagh HJ, Hassan MH, Innes NP, Elkodary HM, Little J, Mossey PA. Passive smoking in the etiology of non-syndromic orofacial clefts: a systematic } \\
\text { review and meta-analysis. PloS one. 2015;10(3):e0116963. }\end{array}$ & Non-orthodontic subject \\
\hline 645 & Sahney S. A review of calcium channel antagonists in the treatment of pediatric hypertension. Pediatric Drugs. 2006;8(6):357-73. & Non-orthodontic subject \\
\hline 646 & $\begin{array}{l}\text { Salam RA, Zuberi NF, Bhutta ZA. Pyridoxine (vitamin B6) supplementation during pregnancy or labour for maternal and neonatal outcomes. Cochrane } \\
\text { Database Syst Rev 2015(6):Cd000179. }\end{array}$ & Non-orthodontic subject \\
\hline 647 & $\begin{array}{l}\text { Salmasi G, Grady R, Jones J, McDonald SD. Environmental tobacco smoke exposure and perinatal outcomes: a systematic review and meta-analyses. } \\
\text { Acta Obstetricia Et Gynecologica Scandinavica. 2010;89(4):423-41. }\end{array}$ & Non-orthodontic subject \\
\hline 648 & $\begin{array}{l}\text { Salvi GE, Lang NP. The effects of non-steroidal anti-inflammatory drugs (selective and non-selective) on the treatment of periodontal diseases. Current } \\
\text { Pharmaceutical Design. } 2005 ; 11(14): 1757-69 \text {. }\end{array}$ & Non-orthodontic subject \\
\hline 649 & $\begin{array}{l}\text { Sansare K, Raghav M, Mallya SM, Karjodkar F. Management-related outcomes and radiographic findings of idiopathic condylar resorption: a systematic } \\
\text { review. International journal of oral and maxillofacial surgery. } 2015 ; 44(2): 209-16 \text {. }\end{array}$ & Non-orthodontic subject \\
\hline 650 & $\begin{array}{l}\text { Santiago JF, De Souza Batista VE, Verri FR, Honório HM, De Mello CC, Almeida DAD, et al. Platform-switching implants and bone preservation: A } \\
\text { systematic review and meta-analysis. International journal of oral and maxillofacial surgery. } 2016 ; 45(3): 332-45 \text {. }\end{array}$ & Non-orthodontic subject \\
\hline 651 & $\begin{array}{l}\text { Sasongko TH, Ismail NFD, Nik Abdul Malik NMA, Zabidi-Hussin ZAMH. Rapamycin and its analogues (rapalogs) for Tuberous Sclerosis Complex- } \\
\text { associated tumors: A systematic review on non-randomized studies using meta-analysis. Orphanet Journal of Rare Diseases. 2015;10(1). }\end{array}$ & Non-orthodontic subject \\
\hline 652 & $\begin{array}{l}\text { Saxton AT, Poenaru D, Ozgediz D, Ameh EA, Farmer D, Smith ER, et al. Economic analysis of children's surgical care in low- and middle-income } \\
\text { countries: A systematic review and analysis. PloS one. 2016;11(10). }\end{array}$ & Non-orthodontic subject \\
\hline 653 & $\begin{array}{l}\text { Sayehmiri F, Sayehmiri K, Asadollahi K, Soroush S, Bogdanovic L, Azizi Jalilian F, et al. The prevalence rate of Porphyromonas gingivalis and its } \\
\text { association with cancer: A systematic review and meta-analysis. International Journal of Immunopathology and Pharmacology. 2015;28(2):160-7. }\end{array}$ & Non-orthodontic subject \\
\hline 654 & Schellenberg JC. Preterm birth: A review. Current Women's Health Reviews. 2006;2(4):257-318. & Non-orthodontic subject \\
\hline 655 & $\begin{array}{l}\text { Scholz CJ, Jungwirth S, Danielczyk W, Weber H, Wichart I, Tragl KH, et al. Investigation of association of serotonin transporter and monoamine oxidase-A } \\
\text { genes with Alzheimer's disease and depression in the VITA study cohort: a } 90 \text {-month longitudinal study. American journal of medical genetics Part B, } \\
\text { Neuropsychiatric genetics : the official publication of the International Society of Psychiatric Genetics. } 2014 ; 165 \mathrm{~b}(2): 184-91 \text {. }\end{array}$ & Non-orthodontic subject \\
\hline 656 & $\begin{array}{l}\text { Schrem H, Lück R, Becker T, Nashan B, Klempnauer J. Update on liver transplantation using cyclosporine. Transplantation Proceedings. } \\
\text { 2004;36(9):2525-31. }\end{array}$ & Non-orthodontic subject \\
\hline 657 & Schroeder M, Reis A, Luque-Martinez I, Loguercio AD, Masterson D, Maia LC. Effect of enamel bevel on retention of cervical composite resin restorations: & Non-orthodontic subject \\
\hline
\end{tabular}




\begin{tabular}{|c|c|c|}
\hline & A systematic review and meta-analysis. Journal of dentistry. 2015;43(7):777-88. & \\
\hline 658 & $\begin{array}{l}\text { Schwartz DA, Herdman CR. Review article: The medical treatment of Crohn's perianal fistulas. Alimentary Pharmacology and Therapeutics. } \\
\text { 2004;19(9):953-67. }\end{array}$ & Non-orthodontic subject \\
\hline 659 & $\begin{array}{l}\text { Schwendicke F, Karimbux N, Allareddy V, Gluud C. Periodontal treatment for preventing adverse pregnancy outcomes: a meta- and trial sequential } \\
\text { analysis. PloS one. } 2015 ; 10(6): e 0129060 \text {. }\end{array}$ & Non-orthodontic subject \\
\hline 660 & $\begin{array}{l}\text { Scott MA, Nguyen VT, Levi B, James AW. Current methods of adipogenic differentiation of mesenchymal stem cells. Stem cells and development. } \\
2011 ; 20(10): 1793-804 \text {. }\end{array}$ & Non-orthodontic subject \\
\hline 661 & $\begin{array}{l}\text { Senna P, Del Bel Cury A, Rosing C. Non-carious cervical lesions and occlusion: a systematic review of clinical studies. Journal of oral rehabilitation. } \\
2012 ; 39(6): 450-62 \text {. }\end{array}$ & Non-orthodontic subject \\
\hline 662 & $\begin{array}{l}\text { Sfyroeras GS, Roussas N, Saleptsis VG, Argyriou C, Giannoukas AD. Association between periodontal disease and stroke. Journal of Vascular Surgery. } \\
2012 ; 55(4): 1178-84 \text {. }\end{array}$ & Non-orthodontic subject \\
\hline 663 & $\begin{array}{l}\text { Sgolastra F, Petrucci A, Gatto R, Marzo G, Monaco A. Photodynamic therapy in the treatment of chronic periodontitis: A systematic review and meta- } \\
\text { analysis. Lasers in medical science. } 2013 ; 28(2): 669-82 \text {. }\end{array}$ & Non-orthodontic subject \\
\hline 664 & $\begin{array}{l}\text { Sgolastra F, Petrucci A, Gatto R, Monaco A. Efficacy of Er:YAG laser in the treatment of chronic periodontitis: Systematic review and meta-analysis. } \\
\text { Lasers in medical science. 2012;27(3):661-73. }\end{array}$ & Non-orthodontic subject \\
\hline 665 & $\begin{array}{l}\text { Sgolastra F, Severino M, Gatto R, Monaco A. Effectiveness of diode laser as adjunctive therapy to scaling root planning in the treatment of chronic } \\
\text { periodontitis: A meta-analysis. Lasers in medical science. } 2013 ; 28(5): 1393-402 \text {. }\end{array}$ & Non-orthodontic subject \\
\hline 666 & $\begin{array}{l}\text { Sgolastra F, Severino M, Petrucci A, Gatto R, Monaco A. Nd:YAG laser as an adjunctive treatment to nonsurgical periodontal therapy: A meta-analysis. } \\
\text { Lasers in medical science. } 2014 ; 29(3): 887-95 \text {. }\end{array}$ & Non-orthodontic subject \\
\hline 667 & $\begin{array}{l}\text { Shanbhag S, Dahiya M, Croucher R. The impact of periodontal therapy on oral health-related quality of life in adults: a systematic review. Journal of } \\
\text { clinical periodontology. } 2012 ; 39(8): 725-35 \text {. }\end{array}$ & Non-orthodontic subject \\
\hline 668 & $\begin{array}{l}\text { Shanbhag S, Pandis N, Mustafa K, Nyengaard JR, Stavropoulos A. Alveolar bone tissue engineering in critical-size defects of experimental animal } \\
\text { models: a systematic review and meta-analysis. Journal of tissue engineering and regenerative medicine. } 2016 \text {. }\end{array}$ & Non-orthodontic subject \\
\hline 669 & $\begin{array}{l}\text { Shanbhag S, Pandis N, Mustafa K, Nyengaard JR, Stavropoulos A. Cell Cotransplantation Strategies for Vascularized Craniofacial Bone Tissue } \\
\text { Engineering: A Systematic Review and Meta-Analysis of Preclinical In Vivo Studies. Tissue engineering Part B, Reviews. } 2016 .\end{array}$ & Non-orthodontic subject \\
\hline 670 & $\begin{array}{l}\text { Shao MY, Huang P, Cheng R, Hu T. Interleukin-6 polymorphisms modify the risk of periodontitis: A systematic review and meta-analysis. Journal of } \\
\text { Zhejiang University: Science B. 2009;10(12):920-7. }\end{array}$ & Non-orthodontic subject \\
\hline 671 & $\begin{array}{l}\text { Sharif MO, Fedorowicz Z, Drews P, Nasser M, Dorri M, Newton T, et al. Interventions for the treatment of fractures of the mandibular condyle. Cochrane } \\
\text { Database of Systematic Reviews. 2010; (4). }\end{array}$ & Non-orthodontic subject \\
\hline 672 & $\begin{array}{l}\text { Sharif MO, Tejani-Sharif A, Kenny K, Day PF. A systematic review of outcome measures used in clinical trials of treatment interventions following } \\
\text { traumatic dental injuries. Dent Traumatol 2015;31(6):422-8. }\end{array}$ & Non-orthodontic subject \\
\hline 673 & $\begin{array}{l}\text { Shawky M, Mosleh M, Jan AM, Jadu FM. Meta-analysis of the Incidence of Lingual Nerve Deficits After Mandibular Bilateral Sagittal Split Osteotomy. } \\
\text { Journal of Craniofacial Surgery. } 2016 ; 27(3): 561-4 \text {. }\end{array}$ & Non-orthodontic subject \\
\hline 674 & $\begin{array}{l}\text { Shimoda K. Pharmacogenetic and pharmacokinetic determinants of trajectory of the therapeutic response in patients with panic disorder. Asia-Pacific } \\
\text { Psychiatry. } 2012 ; 4: 41 \text {. }\end{array}$ & Non-orthodontic subject \\
\hline 675 & $\begin{array}{l}\text { Shungin D, Cornelis MC, Divaris K, Holtfreter B, Shaffer JR, Yu YH, et al. Using genetics to test the causal relationship of total adiposity and periodontitis: } \\
\text { Mendelian randomization analyses in the Gene-Lifestyle Interactions and Dental Endpoints (GLIDE) Consortium. International journal of epidemiology. } \\
2015 ; 44(2): 638-50 \text {. }\end{array}$ & Non-orthodontic subject \\
\hline 676 & Sleep complaints: Whenever possible, avoid the use of sleeping pills. Prescrire international. 2008;17(97):206-12. & Non-orthodontic subject \\
\hline 677 & Smith KD, Scott MA, Ketterman E. What interventions can help patients stop using chewing tobacco? Journal of Family Practice. 2005;54(4):368-9. & Non-orthodontic subject \\
\hline 678 & $\begin{array}{l}\text { Soares TR, Fidalgo TK, Quirino AS, Ferreira DM, Chianca TK, Risso PA, et al. Is caries a risk factor for dental trauma? A systematic review and meta- } \\
\text { analysis. Dent Traumatol } 2016 \text {. }\end{array}$ & Non-orthodontic subject \\
\hline 679 & $\begin{array}{l}\text { Song G, Yang P, Hu J, Zhu S, Li Y, Wang Q. The effect of tranexamic acid on blood loss in orthognathic surgery: a meta-analysis of randomized } \\
\text { controlled trials. Oral surgery, oral medicine, oral pathology and oral radiology. 2013;115(5):595-600. }\end{array}$ & Non-orthodontic subject \\
\hline 680 & $\begin{array}{l}\text { Song GD, Yang P, Zhu SS, Luo E, Feng G, Hu J, et al. Tranexamic Acid Reducing Blood Transfusion in Children Undergoing Craniosynostosis Surgery. } \\
\text { Journal of Craniofacial Surgery. 2013;24(1):299-303. }\end{array}$ & Non-orthodontic subject \\
\hline 681 & $\begin{array}{l}\text { Soskolne WA. Re: Impact of local adjuncts to scaling and root planing in periodontal disease therapy: A systematic review. Bonito AJ, Lux L, Lohr KN } \\
(2005 ; 76: 1227-1236) \text { [1]. Journal of periodontology. } 2006 ; 77(2): 323 .\end{array}$ & Non-orthodontic subject \\
\hline 682 & $\begin{array}{l}\text { Souza E, Medeiros AC, Gurgel BC, Sarmento C. Antimicrobial photodynamic therapy in the treatment of aggressive periodontitis: a systematic review and } \\
\text { meta-analysis. Lasers in medical science. 2016;31(1):187-96. }\end{array}$ & Non-orthodontic subject \\
\hline 683 & $\begin{array}{l}\text { Spencer CM, Goa KL, Gillis JC. Tacrolimus. An update of its pharmacology and clinical efficacy in the management of organ transplantation. Drugs. } \\
1997 ; 54(6): 925-75 \text {. }\end{array}$ & Non-orthodontic subject \\
\hline 684 & $\begin{array}{l}\text { Spineli L, Fleming P, Pandis N. Graphical exploration of the impact of direct allocations of missing binary outcome data on classical and network } \\
\text { metaanalysis. European Journal of Epidemiology. } 2016 ; 31: S 193 \text {. }\end{array}$ & Non-orthodontic subject \\
\hline 685 & $\begin{array}{l}\text { Spineli LM, Pandis N, Salanti G. Reporting and handling missing outcome data in mental health: a systematic review of Cochrane systematic reviews and } \\
\text { meta-analyses. Research synthesis methods. 2015;6(2):175-87. }\end{array}$ & Non-orthodontic subject \\
\hline 686 & $\begin{array}{l}\text { Steenen SA, van Wijk AJ, Becking AG. Bad splits in bilateral sagittal split osteotomy: systematic review and meta-analysis of reported risk factors. } \\
\text { International journal of oral and maxillofacial surgery. } 2016 ; 45(8): 971-9 .\end{array}$ & Non-orthodontic subject \\
\hline 687 & $\begin{array}{l}\text { Stokbro K, Aagaard E, Torkov P, Bell RB, Thygesen T. Virtual planning in orthognathic surgery. International journal of oral and maxillofacial surgery. } \\
2014 ; 43(8): 957-65 \text {. }\end{array}$ & Non-orthodontic subject \\
\hline 688 & $\begin{array}{l}\text { Stothard KJ, Tennant PW, Bell R, Rankin J. Maternal overweight and obesity and the risk of congenital anomalies: a systematic review and meta-analysis. } \\
\text { Jama. 2009;301(6):636-50. }\end{array}$ & Non-orthodontic subject \\
\hline 689 & $\begin{array}{l}\text { Stoustrup P, Kristensen KD, Verna C, Küseler A, Pedersen TK, Herlin T. Intra-articular steroid injection for temporomandibular joint arthritis in juvenile } \\
\text { idiopathic arthritis: A systematic review on efficacy and safety. Seminars in Arthritis and Rheumatism. 2013;43(1):63-70. }\end{array}$ & Non-orthodontic subject \\
\hline 690 & $\begin{array}{l}\text { Subramanian J, Anderson VR, Morgaine KC, Thomson WM. The importance of 'student voice' in dental education. European Journal of Dental Education. } \\
2013 ; 17(1): \mathrm{e} 136 \text {-e } 41 .\end{array}$ & Non-orthodontic subject \\
\hline 691 & $\begin{array}{l}\text { Sujanska A, Durdik P, Jesenák M, Banovcin P, Rabasco J, Vitelli O, et al. Obstructive sleep apnea syndrome in children - the recent view on the } \\
\text { treatment. Advances in Respiratory Therapy Research2014. p. 177-90. }\end{array}$ & Non-orthodontic subject \\
\hline 692 & $\begin{array}{l}\text { Sun QY, Feng M, Zhang MZ, Zhang YQ, Cao MF, Bian LX, et al. Effects of periodontal treatment on glycemic control in type } 2 \text { diabetic patients: A meta- } \\
\text { analysis of randomized controlled trials. Chinese Journal of Physiology. } 2014 ; 57(6): 305-14 \text {. }\end{array}$ & Non-orthodontic subject \\
\hline 693 & $\begin{array}{l}\text { Sun Y, Huang Y, Yin A, Pan Y, Wang Y, Wang C, et al. Genome-wide association study identifies a new susceptibility locus for cleft lip with or without a } \\
\text { cleft palate. Nature communications. 2015;6:6414. }\end{array}$ & Non-orthodontic subject \\
\hline 694 & Suresh S, Mahendra J. Multifactorial relationship of obesity and periodontal disease. Journal of Clinical and Diagnostic Research. 2014;8(4). & Non-orthodontic subject \\
\hline 695 & $\begin{array}{l}\text { Tajima N, Noda M, Origasa H, Noto H, Yabe D, Fujita Y, et al. Evidence-based practice guideline for the treatment for diabetes in Japan } 2013 . \\
\text { Diabetology International. } 2015 ; 6(3): 151-87 .\end{array}$ & Non-orthodontic subject \\
\hline 696 & $\begin{array}{l}\text { Takata GS, Chan LS, Morphew T, Mangione-Smith R, Morton SC, Shekelle P. Evidence assessment of the accuracy of methods of diagnosing middle ear } \\
\text { effusion in children with otitis media with effusion. Pediatrics. 2003;112(6 Pt 1):1379-87. }\end{array}$ & Non-orthodontic subject \\
\hline 697 & Tamboli CP. Current Medical Therapy for Chronic Inflammatory Bowel Diseases. Surgical Clinics of North America. 2007;87(3):697-725. & Non-orthodontic subject \\
\hline 698 & Tan HL, Kheirandish-Gozal L, Abel F, Gozal D. Craniofacial syndromes and sleep-related breathing disorders. Sleep medicine reviews. 2016;27:74-88. & Non-orthodontic subject \\
\hline 699 & Tang M, Bian X, Zhao Q. CLPTM1L polymorphism and lung cancer risk. International journal of clinical and experimental medicine. 2015;8(3):3895-900. & Non-orthodontic subject \\
\hline 700 & $\begin{array}{l}\text { Tang M, Wang Y, Han S, Guo S, Wang D. Transforming growth factor-beta3 gene polymorphisms and nonsyndromic cleft lip and palate risk: a meta- } \\
\text { analysis. Genetic testing and molecular biomarkers. 2013;17(12):881-9. }\end{array}$ & Non-orthodontic subject \\
\hline 701 & $\begin{array}{l}\text { Tang MR, Wang YX, Han SY, Guo S, Wang D. SUMO1 genetic polymorphisms may contribute to the risk of nonsyndromic cleft lip with or without palate: a } \\
\text { meta-analysis. Genetic testing and molecular biomarkers. } 2014 ; 18(9): 616-24 \text {. }\end{array}$ & Non-orthodontic subject \\
\hline 702 & $\begin{array}{l}\text { Tanoshima M, Kobayashi T, Tanoshima R, Beyene J, Koren G, Ito S. Risks of congenital malformations in offspring exposed to valproic acid in utero: A } \\
\text { systematic review and cumulative meta-analysis. Clinical pharmacology and therapeutics. } 2015 ; 98(4): 417-41 \text {. }\end{array}$ & Non-orthodontic subject \\
\hline 703 & $\begin{array}{l}\text { Tedesco TK, Bonifacio CC, Calvo AF, Gimenez T, Braga MM, Raggio DP. Caries lesion prevention and arrestment in approximal surfaces in contact with } \\
\text { glass ionomer cement restorations - A systematic review and meta-analysis. International journal of paediatric dentistry. 2016;26(3):161-72. }\end{array}$ & Non-orthodontic subject \\
\hline 704 & $\begin{array}{l}\text { Teeuw WJ, Gerdes VEA, Loos BG. Effect of periodontal treatment on glycemic control of diabetic patients: A systematic review and meta-analysis. } \\
\text { Diabetes Care. } 2010 ; 33(2): 421-7 .\end{array}$ & Non-orthodontic subject \\
\hline 705 & Thaver D, Saeed MA, Bhutta ZA. Pyridoxine (vitamin B6) supplementation in pregnancy. Cochrane Database Syst Rev 2006(2):Cd000179. & Non-orthodontic subject \\
\hline 706 & Thomas WW, Harvey RJ, Rudmik L, Hwang PH, Schlosser RJ. Distribution of topical agents to the paranasal sinuses: An evidence-based review with & Non-orthodontic subject \\
\hline
\end{tabular}




\begin{tabular}{|c|c|c|}
\hline & & \\
\hline 707 & $\begin{array}{l}\text { Timbang M, Gharb B, Rampazzo A, Papay F, Zins J, Doumit G. A systematic review comparing Furlow double-opposing Z-plasty and straight-line } \\
\text { intravelar veloplasty methods of cleft palate repair. Database of Abstracts of Reviews of Effects. 2014; (2):[1014-22 pp.]. }\end{array}$ & Non-orthodontic subject \\
\hline 708 & $\begin{array}{l}\text { Torabinejad M, Dinsbach NA, Turman M, Handysides R, Bahjir K, White SN. Survival of Intentionally Replanted Teeth and Implant-supported Single } \\
\text { Crowns: A Systematic Review. Journal of endodontics. 2015;41(7):992-8. }\end{array}$ & Non-orthodontic subject \\
\hline 709 & Treatment of periodontal disease in pregnancy reduces preterm birth? Journal of the National Medical Association. 2009;101(7):740-1. & Non-orthodontic subject \\
\hline 710 & $\begin{array}{l}\text { Trejo PM, Weltman RL. Favorable periodontal regenerative outcomes from teeth with presurgical mobility: A retrospective study. Journal of } \\
\text { periodontology. 2004;75(11):1532-8. }\end{array}$ & Non-orthodontic subject \\
\hline 711 & $\begin{array}{l}\text { Tseng KC, Zheng XY, Qu XH, Lu EY. Risk of peri-implantitis in patients with diabetes mellitus: A meta-analysis. International journal of clinical and } \\
\text { experimental medicine. 2016;9(8):15986-95. }\end{array}$ & Non-orthodontic subject \\
\hline 712 & Turner D, Griffiths AM. Acute severe ulcerative colitis in children: A systematic review. Inflammatory Bowel Diseases. 2011;17(1):440-9. & Non-orthodontic subject \\
\hline 713 & Uebing A, Rigby ML. The problem of infective endocarditis after transcatheter pulmonary valve implantation. Heart. 2015;101(10):749-51. & Non-orthodontic subject \\
\hline 714 & $\begin{array}{l}\text { Uno K, Nishizawa D, Seo S, Takayama K, Matsumura S, Sakai N, et al. The Piccolo Intronic Single Nucleotide Polymorphism rs 13438494 Regulates } \\
\text { Dopamine and Serotonin Uptake and Shows Associations with Dependence-Like Behavior in Genomic Association Study. Current molecular medicine. } \\
2015 ; 15(3): 265-74 \text {. }\end{array}$ & Non-orthodontic subject \\
\hline 715 & $\begin{array}{l}\text { Van Borsel J Voice and resonance disorders in genetic syndromes: a meta-analysis. Folia phoniatrica et logopaedica : official organ of the International } \\
\text { Association of Logopedics and Phoniatrics (IALP). 2004;56(2):83-92. }\end{array}$ & Non-orthodontic subject \\
\hline 716 & $\begin{array}{l}\text { van der Sanden WJ, Mettes TG, Grol R, Plasschaert AJ, Verdonschot EH. [Topics in clinical dentistry. Trends in the Dutch dental literature]. Nederlands } \\
\text { tijdschrift voor tandheelkunde. 1999;106(10):366-8. }\end{array}$ & Non-orthodontic subject \\
\hline 717 & $\begin{array}{l}\text { Van der Weijden FA, Campbell SL, Dorfer CE, Gonzalez-Cabezas C, Slot DE. Safety of Oscillating-Rotating Powered Brushes Compared to Manual } \\
\text { Toothbrushes: A Systematic Review. Journal of periodontology. 2011;82(1):5-24. }\end{array}$ & Non-orthodontic subject \\
\hline 718 & $\begin{array}{l}\text { Varela-López A, Battino M, Bullón P, Quiles JL. Dietary antioxidants for chronic periodontitis prevention and its treatment. A review on current evidences } \\
\text { from animal and human studies. Ars Pharmaceutica. 2015;56(3):131-40. }\end{array}$ & Non-orthodontic subject \\
\hline 719 & $\begin{array}{l}\text { Vene N, Mavri A, Sinigoj P, Kosmelj K, Vizintin-Cuderman T, Tratar G, et al. Higher risk of minor bleeding in women than in men with atrial fibrillation } \\
\text { treated with dabigatran. Thrombosis Research. 2014;133:S40. }\end{array}$ & Non-orthodontic subject \\
\hline 720 & $\begin{array}{l}\text { Venezia E, Goldstein M, Boyan BD, Schwartz Z. The use of enamel matrix derivative in the treatment of periodontal defects: A literature review and meta- } \\
\text { analysis. Critical Reviews in Oral Biology and Medicine. 2004;15(6):382-402. }\end{array}$ & Non-orthodontic subject \\
\hline 721 & $\begin{array}{l}\text { Venkatesan S, Leonardi-Bee J, Myles P, McNeill A. A systematic review and meta-analysis on the health effects of non-snus smokeless tobacco products. } \\
\text { Respiratory Medicine. 2013;107:S10. }\end{array}$ & Non-orthodontic subject \\
\hline 722 & $\begin{array}{l}\text { Verkleij-Hagoort A, Bliek J, Sayed-Tabatabaei F, Ursem N, Steegers E, Steegers-Theunissen R. Hyperhomocysteinemia and MTHFR polymorphisms in } \\
\text { association with orofacial clefts and congenital heart defects: a meta-analysis. American journal of medical genetics Part A. 2007;143a(9):952-60. }\end{array}$ & Non-orthodontic subject \\
\hline 723 & $\begin{array}{l}\text { Viana KA, Daher A, Maia LC, Costa PS, Martins CC, Paiva SM, et al. Memory effects of sedative drugs in children and adolescents--protocol for a } \\
\text { systematic review. Systematic reviews. 2016;5:34. }\end{array}$ & Non-orthodontic subject \\
\hline 724 & $\begin{array}{l}\text { Victora CG, Bahl R, Barros AJ, Franca GV, Horton S, Krasevec J, et al. Breastfeeding in the 21st century: epidemiology, mechanisms, and lifelong effect. } \\
\text { Lancet (London, England). 2016;387(10017):475-90. }\end{array}$ & Non-orthodontic subject \\
\hline 725 & $\begin{array}{l}\text { Vieira AR, Orioli IM, Murray JC. Maternal age and oral clefts: a reappraisal. Oral surgery, oral medicine, oral pathology, oral radiology, and endodontics. } \\
\text { 2002;94(5):530-5. }\end{array}$ & Non-orthodontic subject \\
\hline 726 & Vieira AR, Orioli IM. Birth order and oral clefts: a meta analysis. Teratology. 2002;66(5):209-16. & Non-orthodontic subject \\
\hline 727 & $\begin{array}{l}\text { Vissink A, Burlage FR, Spijkervet FKL, Jansma J, Coppes RP. Prevention and treatment of the consequences of head and neck radiotherapy. Critical } \\
\text { Reviews in Oral Biology and Medicine. 2003;14(3):213-25. }\end{array}$ & Non-orthodontic subject \\
\hline 728 & $\begin{array}{l}\text { Vlachojannis JE, Cameron M, Chrubasik S. A systematic review on the Sambuci fructus effect and efficacy profiles. Phytotherapy Research. 2010;24(1):1- } \\
8 \text {. }\end{array}$ & Non-orthodontic subject \\
\hline 729 & $\begin{array}{l}\text { Vrijheid M, Martinez D, Manzanares S, Dadvand P, Schembari A, Rankin J, et al. Ambient air pollution and risk of congenital anomalies: a systematic } \\
\text { review and meta-analysis. Environmental health perspectives. 2011;119(5):598-606. }\end{array}$ & Non-orthodontic subject \\
\hline 730 & $\begin{array}{l}\text { Vucic S, Drost RW, Ongkosuwito EM, Wolvius EB. Dentofacial trauma and players' attitude towards mouthguard use in field hockey: a systematic review } \\
\text { and meta-analysis. British journal of sports medicine. 2016;50(5):298-304. }\end{array}$ & Non-orthodontic subject \\
\hline 731 & Wald NJ, Oakley GP, Hubner RA, Houlston RD, Muir KR. Should folic acid fortification be mandatory? British Medical Journal. 2007;334(7606):1252-3. & Non-orthodontic subject \\
\hline 732 & Wallace CA. Current management of juvenile idiopathic arthritis. Best Practice and Research: Clinical Rheumatology. 2006;20(2):279-300. & Non-orthodontic subject \\
\hline 733 & $\begin{array}{l}\text { Wang F, Wu Y, Zou D, Wang G, Kaigler D. Clinical outcomes of dental implant therapy in alveolar cleft patients: a systematic review. Database of } \\
\text { Abstracts of Reviews of Effects. 2014; (2):[1098-105 pp.]. }\end{array}$ & Non-orthodontic subject \\
\hline 734 & $\begin{array}{l}\text { Wang LF, Long H, Deng M, Xu H, Fang J, Fan Y, et al. Biofeedback treatment for sleep bruxism: a systematic review. Sleep \& breathing = Schlaf \& } \\
\text { Atmung. 2014;18(2):235-42. }\end{array}$ & Non-orthodontic subject \\
\hline 735 & $\begin{array}{l}\text { Wang M, Pan Y, Zhang Z, Wang L. Three polymorphisms in IRF6 and 8q24 are associated with nonsyndromic cleft lip with or without cleft palate: } \\
\text { evidence from } 20 \text { studies. American journal of medical genetics Part A. 2012;158a(12):3080-6. }\end{array}$ & Non-orthodontic subject \\
\hline 736 & $\begin{array}{l}\text { Wang TF, Jen IA, Chou C, Lei YP. Effects of periodontal therapy on metabolic control in patients with type } 2 \text { diabetes mellitus and periodontal disease: A } \\
\text { meta-analysis. Medicine (United States). 2014;93(28):e292. }\end{array}$ & Non-orthodontic subject \\
\hline 737 & $\begin{array}{l}\text { Wang WF, Shi J, Chen SJ, Niu YM, Zeng XT. Interleukin-1a -899 (+4845) C } \rightarrow \text { T polymorphism is not associated with aggressive periodontitis } \\
\text { susceptibility: A meta-analysis based on } 19 \text { case-control studies. Biomedical Reports. 2014;2(3):378-83. }\end{array}$ & Non-orthodontic subject \\
\hline 738 & $\begin{array}{l}\text { Wang X, Han X, Guo X, Luo X, Wang D. The effect of periodontal treatment on hemoglobin A1c levels of diabetic patients: A systematic review and meta- } \\
\text { analysis. PloS one. 2014;9(9). }\end{array}$ & Non-orthodontic subject \\
\hline 739 & $\begin{array}{l}\text { Wang Y, Hu X, Li X, Wang Z. An overview of the effect of sodium glucose cotransporter } 2 \text { inhibitor monotherapy on glycemic and other clinical laboratory } \\
\text { parameters in type } 2 \text { diabetes patients. Therapeutics and Clinical Risk Management. 2016;12:1113-31. }\end{array}$ & Non-orthodontic subject \\
\hline 740 & $\begin{array}{l}\text { Wang Y, Peng J, Li Y, Luo H, Huang G, Luo S, et al. Association between tooth loss and risk of oesophageal cancer: a dose-response meta-analysis. } \\
\text { SpringerPlus. 2016;5(1):1020. }\end{array}$ & Non-orthodontic subject \\
\hline 741 & $\begin{array}{l}\text { Wasiak J, Shen AY, Tan HB, Mahar R, Kan G, Khoo WR, et al. Methodological quality assessment of paper-based systematic reviews published in oral } \\
\text { health. Clinical oral investigations. } 2016 ; 20(3): 399-431 \text {. }\end{array}$ & Non-orthodontic subject \\
\hline 742 & $\begin{array}{l}\text { Watanabe T, Ishiguro S, Ueda M, Saeki Y, Hayashi Y, Shimoda K. Pharmacokinetic and pharmacogenetic factors affecting the initial therapeutic effect of } \\
\text { selective serotonin reuptake inhibitor in panic disorder. Panic Disorder: Symptoms, Treatment and Prevention2012. p. } 79-94 .\end{array}$ & Non-orthodontic subject \\
\hline 743 & $\begin{array}{l}\text { Watanabe T, Ishiguro S, Ueda M, Saeki Y, Hayashi Y, Shimoda K. Pharmacokinetic and pharmacogenetic factors affecting the initial therapeutic effect of } \\
\text { selective serotonin reuptake inhibitor. Psychiatry Research Journal. 2012;3(1-2):59-70. }\end{array}$ & Non-orthodontic subject \\
\hline 744 & $\begin{array}{l}\text { Wattanawong K, Rattanasiri S, McEvoy M, Attia J, Thakkinstian A. Association between IRF6 and 8q24 polymorphisms and nonsyndromic cleft lip with or } \\
\text { without cleft palate: Systematic review and meta-analysis. Birth defects research Part A, Clinical and molecular teratology. 2016;106(9):773-88. }\end{array}$ & Non-orthodontic subject \\
\hline 745 & $\begin{array}{l}\text { Webster AC, Woodroffe RC, Taylor RS, Chapman JR, Craig JC. Tacrolimus versus ciclosporin as primary immunosuppression for kidney transplant } \\
\text { recipients: Meta-analysis and meta-regression of randomised trial data. British Medical Journal. 2005;331(7520):810-4. }\end{array}$ & Non-orthodontic subject \\
\hline 746 & $\begin{array}{l}\text { Weiss JP, Sawhney R. Update on mandibular condylar fracture management. Current Opinion in Otolaryngology and Head and Neck Surgery. } \\
\text { 2016;24(4):273-8. }\end{array}$ & Non-orthodontic subject \\
\hline 747 & $\begin{array}{l}\text { Wen PY, Schiff D, Kesari S, Drappatz J, Gigas DC, Doherty L. Medical management of patients with brain tumors. Journal of Neuro-Oncology. } \\
\text { 2006;80(3):313-32. }\end{array}$ & Non-orthodontic subject \\
\hline 748 & $\begin{array}{l}\text { Wen YF, Wong HM, Lin R, Yin G, McGrath C. Inter-Ethnic/Racial Facial Variations: A Systematic Review and Bayesian Meta-Analysis of Photogram } \\
\text { Studies. PloS one. 2015;10(8):e0134525. }\end{array}$ & Non-orthodontic subject \\
\hline 749 & $\begin{array}{l}\text { Weng H, Zhang C, Hu YY, Yuan RX, Zuo HX, Yan JZ, et al. Association between Estrogen Receptor- } \alpha \text { Gene Xbal and Pvull Polymorphisms and } \\
\text { Periodontitis Susceptibility: A Meta-Analysis. Disease markers. 2015;2015. }\end{array}$ & Non-orthodontic subject \\
\hline 750 & $\begin{array}{l}\text { Wenzel-Seifert K, Stegmann B, Wild M, Haen E. Cardiovascular side effects of atomoxetine, methylphenidate, amfetamine, dexamfetamine and } \\
\text { lisdexamfetamine for treatment of ADHD. Psychopharmakotherapie. 2015;22(1):42-6. }\end{array}$ & Non-orthodontic subject \\
\hline 751 & $\begin{array}{l}\text { Weston P, Yaziz YA, Moles DR, Needleman I. Occlusal interventions for periodontitis in adults. Cochrane Database of Systematic Reviews. 2016; (11). } \\
\text { Available from: http://onlinelibrary.wiley.com/doi/10.1002/14651858.CD004968.pub3/abstract }\end{array}$ & Non-orthodontic subject \\
\hline 752 & Weston P, Yaziz YA, Moles DR, Needleman I. Occlusal interventions for periodontitis in adults. Cochrane Database Syst Rev 2008(3):Cd004968. & Non-orthodontic subject \\
\hline 753 & What's new in contact dermatitis? Metal allergies. Journal of Drugs in Dermatology. 2009;8(3):307-8. & Non-orthodontic subject \\
\hline 754 & Whitehill TL. Assessing intelligibility in speakers with cleft palate: a critical review of the literature. Cleft Palate Craniofac J 2002;39(1):50-8. & Non-orthodontic subject \\
\hline 755 & $\begin{array}{l}\text { Williams B, Poulter NR, Brown MJ, Davis M, McInnes GT, Potter JF, et al. Guidelines for management of hypertension: Report of the fourth working party } \\
\text { of the Bristish Hypertension Society, 2004 - BHS IV. Journal of Human Hypertension. 2004;18(3):139-85. }\end{array}$ & Non-orthodontic subject \\
\hline 756 & Williams R. Meta-analysis of calcineurin inhibitors in renal transplantation. Nature Clinical Practice Nephrology. 20 & Non-orthodontic subject \\
\hline
\end{tabular}




\begin{tabular}{|c|c|c|}
\hline 757 & $\begin{array}{l}\text { Wilson JJ. Predictors of death: A life-history approach for understanding oral health patterns during the late prehistoric period in the Eastern Woodlands. } \\
\text { American Journal of Physical Anthropology. 2012;147:305. }\end{array}$ & Non-orthodontic subject \\
\hline 758 & $\begin{array}{l}\text { Wolff T, Shelton E, Sessions C, Miller T. Screening for syphilis infection in pregnant women: Evidence for the U.S. Preventive Services Task Force } \\
\text { reaffirmation recommendation statement. Annals of Internal Medicine. } 2009 ; 150(10): 710-6+W-125 .\end{array}$ & Non-orthodontic subject \\
\hline 759 & $\begin{array}{l}\text { Woodroffe R, Yao GL, Meads C, Bayliss S, Ready A, Raftery J, et al. Clinical and cost-effectiveness of newer immunosuppressive regimens in renal } \\
\text { transplantation: A systematic review and modelling study. Health Technology Assessment. 2005;9(21):i-179. }\end{array}$ & Non-orthodontic subject \\
\hline 760 & $\begin{array}{l}\text { Woolacott N, Vergel YB, Hawkins N, Kainth A, Khadjesari Z, Misso K, et al. Etanercept and infliximab for the treatment of psoriatic arthritis: A systematic } \\
\text { review and economic evaluation. Health Technology Assessment. 2006;10(31):iii-78. }\end{array}$ & Non-orthodontic subject \\
\hline 761 & $\begin{array}{l}\text { Wu FL, Wang LY, Huang YQ, Guo WB, Liu CD, Li SG. Interleukin-1beta }+3954 \text { polymorphisms and risk of external apical root resorption in orthodontic } \\
\text { treatment: a meta-analysis. Genetics and molecular research : GMR. 2013;12(4):4678-86. }\end{array}$ & Non-orthodontic subject \\
\hline 762 & $\begin{array}{l}\text { Wu J, Chen Y, Pei J, Pan J. MTHFD1 gene polymorphisms as risk factors involved in orofacial cleft: an independent case-control study and a meta- } \\
\text { analysis. International journal of clinical and experimental medicine. } 2015 ; 8(5): 7737-45 \text {. }\end{array}$ & Non-orthodontic subject \\
\hline 763 & $\begin{array}{l}\text { Wu J, Li B, Lin X. Histological outcomes of sinus augmentation for dental implants with calcium phosphate or deproteinized bovine bone: a systematic } \\
\text { review and meta-analysis. International journal of oral and maxillofacial surgery. } 2016 ; 45(11): 1471-7 \text {. }\end{array}$ & Non-orthodontic subject \\
\hline 764 & Wu Y, Li C, Pan J. Two different opinions on a published systematic review. International journal of oral and maxillofacial surgery. 2012;41(7):882. & Non-orthodontic subject \\
\hline 765 & $\begin{array}{l}\text { Wusiman P, Yarbag A, Wurouzi G, Mijiti A, Moming A. Three dimensional versus standard miniplate fixation in management of mandibular fractures: A } \\
\text { systematic review and meta-analysis. J Craniomaxillofac Surg 2016;44(10):1646-54. }\end{array}$ & Non-orthodontic subject \\
\hline 766 & Wyszynski DF, Duffy DL, Beaty TH. Maternal cigarette smoking and oral clefts: a meta-analysis. Cleft Palate Craniofac J 1997;34(3):206-10. & Non-orthodontic subject \\
\hline 767 & Xiao ZG, Jin J. Clinical evaluation of subantimicrobial dose doxycycline in treatment of periodontitis. Pharmaceutical Care and Research. 2007;7(1):25-7. & Non-orthodontic subject \\
\hline 768 & Xiao-Ping W, Wei L, Yu-Shan H. Correlation between chronic periodontitis and cardiovascular diseases: A systematic review. Heart. 2012;98:E93-E4. & Non-orthodontic subject \\
\hline 769 & $\begin{array}{l}\text { Xu Q, Liu JW, Yuan Y. Comprehensive assessment of the association between miRNA polymorphisms and gastric cancer risk. Mutation Research- } \\
\text { Reviews in Mutation Research. 2015;763:148-60. }\end{array}$ & Non-orthodontic subject \\
\hline 770 & $\begin{array}{l}\text { Xu R, Lian Y, Li WX. Airway Complications during and after General Anesthesia: A Comparison, Systematic Review and Meta-Analysis of Using Flexible } \\
\text { Laryngeal Mask Airways and Endotracheal Tubes. PloS one. 2016;11(7):e0158137. }\end{array}$ & Non-orthodontic subject \\
\hline 771 & $\begin{array}{l}\text { Xuan Z, Zhongpeng Y, Yanjun G, Jiaqi D, Yuchi Z, Bing S, et al. Maternal active smoking and risk of oral clefts: a meta-analysis. Oral surgery, oral } \\
\text { medicine, oral pathology and oral radiology. 2016;122(6):680-90. }\end{array}$ & Non-orthodontic subject \\
\hline 772 & $\begin{array}{l}\text { Yaacob M, Worthington HV, Deacon SA, Deery C, Walmsley AD, Robinson PG, et al. Powered versus manual toothbrushing for oral health. Cochrane } \\
\text { Database of Systematic Reviews. 2014(6). }\end{array}$ & Non-orthodontic subject \\
\hline 773 & $\begin{array}{l}\text { Yakoob M, Bateman B, Ho E, Hernandez-Diaz S, Franklin J, Goodman J, et al. The risk of congenital malformations associated with exposure to beta- } \\
\text { blockers early in pregnancy: a meta-analysis. Hypertension (Dallas, Tex : 1979). 2013; 62(2):[375-81 pp.]. }\end{array}$ & Non-orthodontic subject \\
\hline 774 & $\begin{array}{l}\text { Yakoob MY, Bateman BT, Ho E, Hernandez-Diaz S, Franklin JM, Goodman JE, et al. The risk of congenital malformations associated with exposure to } \\
\text { beta-blockers early in pregnancy: a meta-analysis. Hypertension (Dallas, Tex : 1979). 2013;62(2):375-81. }\end{array}$ & Non-orthodontic subject \\
\hline 775 & $\begin{array}{l}\text { Yan M, Liu M, Wang M, Yin F, Xia H. The effects of Er:YAG on the treatment of peri-implantitis: a meta-analysis of randomized controlled trials. Lasers in } \\
\text { medical science. } 2015 ; 30(7): 1843-53 \text {. }\end{array}$ & Non-orthodontic subject \\
\hline 776 & $\begin{array}{l}\text { Yan XZ, Yang F, Jansen JA, De Vries RBM, Van Den Beucken JJJP. Cell-based approaches in periodontal regeneration: A systematic review and meta- } \\
\text { analysis of periodontal defect models in animal experimental work. Tissue Engineering - Part B: Reviews. 2015;21(5):411-26. }\end{array}$ & Non-orthodontic subject \\
\hline 777 & $\begin{array}{l}\text { Yang LY, Xu MB, Jin XL, Xu JJ, Lu JJ, Zhang C, et al. Complications of Absorbable Fixation in Maxillofacial Surgery: A Meta-Analysis. PloS one. } \\
2013 ; 8(6) \text {. }\end{array}$ & Non-orthodontic subject \\
\hline 778 & Yang W, Hu L, Wang Z, Nie G, Li X, Lin D, et al. Deep Neck Infection: A Review of 130 Cases in Southern China. Medicine. 2015;94(27):e994. & Non-orthodontic subject \\
\hline 779 & Yang X, Hou D, Jiang W, Zhang C. Intercellular protein-protein interactions at synapses. Protein and Cell. 2014;5(6):420-44. & Non-orthodontic subject \\
\hline 780 & $\begin{array}{l}\text { Yao G, Albon E, Adi Y, Milford D, Bayliss S, Ready A, et al. A systematic review and economic model of the clinical and cost-effectiveness of } \\
\text { immunosuppressive therapy for renal transplantation in children. Health Technology Assessment. 2006;10(49):iii-65. }\end{array}$ & Non-orthodontic subject \\
\hline 781 & Yao QW, Zhou DS, Peng HJ, Ji P, Liu DS. Association of periodontal disease with oral cancer: A meta-analysis. Tumor Biology. 2014;35(7):7073-7. & Non-orthodontic subject \\
\hline 782 & $\begin{array}{l}\text { Yao S, Zhou J, Li Z. Contrast analysis of open reduction and internal fixation and non-surgical treatment of condylar fracture: a meta-analysis. The Journal } \\
\text { of craniofacial surgery. } 2014 ; 25(6): 2077-80 \text {. }\end{array}$ & Non-orthodontic subject \\
\hline 783 & $\begin{array}{l}\text { Ye Z, Lu H, Guo W, Dai W, Li H, Yang H, et al. The effect of alprostadil on preventing contrast-induced nephropathy for percutaneous coronary } \\
\text { intervention in diabetic patients: A systematic review and meta-analysis. Medicine. 2016;95(46):e5306. }\end{array}$ & Non-orthodontic subject \\
\hline 784 & $\begin{array}{l}\text { Yengopal V, Mickenautsch S. Caries-preventive effect of resin-modified glass-ionomer cement (RM-GIC) versus composite resin: a quantitative systematic } \\
\text { review. Eur Arch Paediatr Dent 2011;12(1):5-14. }\end{array}$ & Non-orthodontic subject \\
\hline 785 & $\begin{array}{l}\text { Yin WT, Pan YP, Lin L. Association between IL-1 } \alpha \text { rs17561 and IL-1 } \beta \text { rs1143634 polymorphisms and periodontitis: A meta-analysis. Genetics and } \\
\text { Molecular Research. 2016;15(1). }\end{array}$ & Non-orthodontic subject \\
\hline 786 & $\begin{array}{l}\text { Yin XH, Wang YD, Luo H, Zhao K, Huang GL, Luo SY, et al. Association between Tooth Loss and Gastric Cancer: A Meta-Analysis of Observational } \\
\text { Studies. PloS one. 2016;11(3):e0149653. }\end{array}$ & Non-orthodontic subject \\
\hline 787 & $\begin{array}{l}\text { Zachariae H, Steen Olsen T. Efficacy of cyclosporin A (CyA) in psoriasis: An overview of dose/response, indications, contraindications and side-effects. } \\
\text { Clinical Nephrology. 1995;43(3):154-8. }\end{array}$ & Non-orthodontic subject \\
\hline 788 & $\begin{array}{l}\text { Zaghi S, Holty JE, Certal V, Abdullatif J, Guilleminault C, Powell NB, et al. Maxillomandibular Advancement for Treatment of Obstructive Sleep Apnea: A } \\
\text { Meta-analysis. JAMA otolaryngology-- head \& neck surgery. 2016;142(1):58-66. }\end{array}$ & Non-orthodontic subject \\
\hline 789 & $\begin{array}{l}\text { Zang Y, Nie W, Fang Z, Li B. Cleft lip and palate transmembrane protein } 1 \text { rs31489 polymorphism is associated with lung cancer risk: a meta-analysis. } \\
\text { Tumour biology : the journal of the International Society for Oncodevelopmental Biology and Medicine. } 2014 ; 35(6): 5583-8 \text {. }\end{array}$ & Non-orthodontic subject \\
\hline 790 & $\begin{array}{l}\text { Zeiger JS, Beaty TH, Liang KY. Oral clefts, maternal smoking, and TGFA: a meta-analysis of gene-environment interaction. Cleft Palate Craniofac J } \\
2005 ; 42(1): 58-63 \text {. }\end{array}$ & Non-orthodontic subject \\
\hline 791 & Zeiger JS, Beaty TH. Is there a relationship between risk factors for oral clefts? Teratology. 2002;66(5):205-8. & Non-orthodontic subject \\
\hline 792 & Zeller T, Blankenberg S, Diemert P. Genomewide association studies in cardiovascular disease - An update 2011. Clinical Chemistry. 2012;58(1):92-103. & Non-orthodontic subject \\
\hline 793 & $\begin{array}{l}\text { Zhang DZ, Liu XY, Xiao WL, Xu YX. Botulinum Toxin Type A and the Prevention of Hypertrophic Scars on the Maxillofacial Area and Neck: A Meta- } \\
\text { Analysis of Randomized Controlled Trials. PloS one. 2016;11(3). }\end{array}$ & Non-orthodontic subject \\
\hline 794 & $\begin{array}{l}\text { Zhang H, Zhou L, Han Y, Cai Q, Li D, Pan Y, et al. Associations between CD14 -159 C>T polymorphism and chronic/aggressive periodontitis } \\
\text { susceptibility. Oral Diseases. 2013;19(8):805-11. }\end{array}$ & Non-orthodontic subject \\
\hline 795 & $\begin{array}{l}\text { Zhang J, Yang J, Chang X, Zhang C, Zhou H, Liu M. Ozagrel for acute ischemic stroke: A metaanalysis of data from randomized controlled trials. } \\
\text { Neurological Research. 2012;34(4):346-53. }\end{array}$ & Non-orthodontic subject \\
\hline 796 & Zhang LL, Zeng LN, Li YP. Side effects of phenobarbital in epilepsy: A systematic review. Epileptic Disorders. 2011;13(4):349-65. & Non-orthodontic subject \\
\hline 797 & $\begin{array}{l}\text { Zhang M, Wu X, Lu W, Ge Y, Wang X, Cai Z, et al. Rs401681 polymorphism in TERT-CLPTM1L was associated with bladder cancer risk: A meta- } \\
\text { analysis. Iranian journal of basic medical sciences. 2015;18(11):1130-6. }\end{array}$ & Non-orthodontic subject \\
\hline 798 & $\begin{array}{l}\text { Zhang W, Qu HC, Zhang Y. Association of MSX1 and TGF-beta1 genetic polymorphisms with hypodontia: meta-analysis. Genetics and molecular } \\
\text { research : GMR. 2014;13(4):10007-16. }\end{array}$ & Non-orthodontic subject \\
\hline 799 & $\begin{array}{l}\text { Zhang W, Qu HC, Zhang Y. PAX-9 polymorphism may be a risk factor for hypodontia: a meta-analysis. Genetics and molecular research : GMR. } \\
\text { 2014;13(4):9997-10006. }\end{array}$ & Non-orthodontic subject \\
\hline 800 & $\begin{array}{l}\text { Zhang Y, Yu Q, Yu W, Hu M. Glutathione S-transferase M1 null genotype is associated with increased risk of oral cancer in East Asians: a meta-analysis. } \\
\text { Tumour biology : the journal of the International Society for Oncodevelopmental Biology and Medicine. 2013;34(5):3183-8. }\end{array}$ & Non-orthodontic subject \\
\hline 801 & $\begin{array}{l}\text { Zhang YH, Sun YL, Ma T, Zhao J. Efficacy of systemic antibiotic combined with non-surgical periodontal therapy for aggressive periodontitis: A meta- } \\
\text { analysis. Chinese Journal of Evidence-Based Medicine. } 2016 ; 16(5): 585-91 .\end{array}$ & Non-orthodontic subject \\
\hline 802 & $\begin{array}{l}\text { Zhao H, Zhang J, Zhang M, Deng F, Zheng L, Zheng H, et al. Is MTHFD1 polymorphism rs } 2236225 \text { (c.1958G>A) associated with the susceptibility of } \\
\text { NSCL/P? A systematic review and meta-analysis. F1000Research. 2015;4:142. }\end{array}$ & Non-orthodontic subject \\
\hline 803 & $\begin{array}{l}\text { Zhao M, Ren Y, Shen L, Zhang Y, Zhou B. Association between MTHFR C677T and A1298C polymorphisms and NSCL/P risk in Asians: a meta-analysis. } \\
\text { PloS one. 2014;9(3):e88242. }\end{array}$ & Non-orthodontic subject \\
\hline 804 & $\begin{array}{l}\text { Zheng J, Hou T, Gao L, Cuiyan W, Wang P, Wen Y, et al. Association between CD14 gene polymorphism and periodontitis: A meta-analysis. Critical } \\
\text { Reviews in Eukaryotic Gene Expression. 2013;23(2):115-23. }\end{array}$ & Non-orthodontic subject \\
\hline 805 & $\begin{array}{l}\text { Zhu HL, Xi Q, Liu LY, Wang JN, Gu MJ. Quantitative Assessment of Common Genetic Variants on FOXE1 and Differentiated Thyroid Cancer Risk. PloS } \\
\text { one. 2014;9(1). }\end{array}$ & Non-orthodontic subject \\
\hline 806 & $\begin{array}{l}\text { Zhu M, Li J, Chen B, Mei L, Yao L, Tian J, et al. The Effect of Calcium Sodium Phosphosilicate on Dentin Hypersensitivity: A Systematic Review and } \\
\text { Meta-Analysis. PloS one. 2015;10(11):e0140176. }\end{array}$ & Non-orthodontic subject \\
\hline 807 & $\begin{array}{l}\text { Al Marzooq A, Yatabe M, Ai M. What types of occlusal factors play a role in temporomandibular disorders...? - A literature review. Journal of medical and } \\
\text { dental sciences. 1999;46(3):111-6. }\end{array}$ & Not a systematic review \\
\hline
\end{tabular}




\begin{tabular}{|c|c|c|}
\hline 808 & $\begin{array}{l}\text { Al-Jewair TS. High-Quality Randomized Controlled Trials are Needed to Confirm the Effectiveness of Oral Appliances in the Management of Obstructive } \\
\text { Sleep Apnea Syndrome. The journal of evidence-based dental practice. } 2016 ; 16(2): 110-2 \text {. }\end{array}$ & Not a systematic review \\
\hline 809 & Al-Mendalawi MD. Timing of dental development in Saudi cleft lip and palate patients. Saudi medical journal. 2014;35(8):915. & Not a systematic review \\
\hline 810 & Bloch KE. Alternatives to CPAP in the treatment of the obstructive sleep apnoea syndrome. Swiss Medical Weekly. 2006;136(17-18):261-7. & Not a systematic review \\
\hline 811 & Chang HP, Tseng YC. Miniscrew implant applications in contemporary orthodontics. Kaohsiung Journal of Medical Sciences. 2014;30(3):111-5. & Not a systematic review \\
\hline 812 & $\begin{array}{l}\text { Chaushu S, Shapira J, Heling I, Becker A. Emergency orthodontic treatment after the traumatic intrusive luxation of maxillary incisors. Am J Orthod } \\
\text { Dentofacial Orthop 2004;126(2):162-72. }\end{array}$ & Not a systematic review \\
\hline 813 & $\begin{array}{l}\text { Cohen-Levy J, Garcia R, Pételle B, Fleury B. Treatment of the obstructive sleep apnea syndrome in adults by mandibular advancement device: The state } \\
\text { of the art. International orthodontics. 2009;7(3):287-304. }\end{array}$ & Not a systematic review \\
\hline 814 & Dersot JM. [Plaque control, a key element of successful orthodontics]. L' Orthodontie francaise. 2010;81(1):33-9. & Not a systematic review \\
\hline 815 & $\begin{array}{l}\text { Esenlik E, Al Awadhi Y, Clouston S, Rubin M, Shetye P, Grayson B. Comparison of cephalometric midface form in patients with uclp, treated with } \\
\text { traditional or No PSIO (eurocleft study) and patients treated with nam (NYU). Cleft Palate-Craniofacial Journal. 2016;53(4):e152. }\end{array}$ & Not a systematic review \\
\hline 816 & Fox NA, McCabe JF, Buckley JG. A critique of bond strength testing in orthodontics. Br J Orthod 1994;21(1):33-43. & Not a systematic review \\
\hline 817 & $\begin{array}{l}\text { Gebeile-Chauty S, Robin O, Messaoudi Y, Aknin JJ. Can orthodontic treatment generate temporomandibular disorders and pain? A review. L' Orthodontie } \\
\text { francaise. 2010;81(1):85-93. }\end{array}$ & Not a systematic review \\
\hline 818 & $\begin{array}{l}\text { Goh HH, Fernandez MLM. Interspace/interdental brushes for oral hygiene in orthodontic patients with fixed appliances. Cochrane Database of Systematic } \\
\text { Reviews. 2013; (9). Available from: http://onlinelibrary.wiley.com/doi/10.1002/14651858.CD005410.pub3/abstract }\end{array}$ & Not a systematic review \\
\hline 819 & $\begin{array}{l}\text { Harrison JE, Scholey J, Worthington HV, Bickley S, O'Brien KD, Shaw BC. Orthodontic treatment for crowded teeth in children. Cochrane Database of } \\
\text { Systematic Reviews. 2002; (1). }\end{array}$ & Not a systematic review \\
\hline 820 & $\begin{array}{l}\text { Isherwood G, Gruber E, Bowyer O, Macbean A. Visual assessment of the bond strength between an orthodontic bracket and an impacted maxillary } \\
\text { canine: The "blue-needle" test. British Journal of Oral and Maxillofacial Surgery. 2013;51(8):988-9. }\end{array}$ & Not a systematic review \\
\hline 821 & Jang JC, Fields HW, Vig KWL, Beck FM. Controversies in the timing of orthodontic treatment. Seminars in orthodontics. 2005;11(3):112-8. & Not a systematic review \\
\hline 822 & $\begin{array}{l}\text { Jokic D, Jokic D, Uglesic V, Macan D, Knezevic P. Soft tissue changes after mandibular setback and bimaxillary surgery in Class III patients. The Angle } \\
\text { orthodontist. 2013;83(5):817-23. }\end{array}$ & Not a systematic review \\
\hline 823 & $\begin{array}{l}\text { Koh H, Robinson PG. Occlusal adjustment for treating and preventing temporomandibular joint disorders. Cochrane Database of Systematic Reviews. } \\
2016 ; 2016(1) \text {. }\end{array}$ & Not a systematic review \\
\hline 824 & $\begin{array}{l}\text { Kozel JA, Macedo CR, Atallah ÁN. Laceback ligatures for controlling anchorage in patients undergoing fixed orthodontic treatment. Cochrane Database of } \\
\text { Systematic Reviews. 2016; (10). }\end{array}$ & Not a systematic review \\
\hline 825 & $\begin{array}{l}\text { Li C, Lv J, Liu M, Shi Z, Glenny A-M. Electronic dental anaesthesia for managing pain during dental procedures. Cochrane Database of Systematic } \\
\text { Reviews. 2016; (2). Available from: http://onlinelibrary.wiley.com/doi/10.1002/14651858.CD012092/abstract }\end{array}$ & Not a systematic review \\
\hline 826 & Li KK. Maxillomandibular advancement for obstructive sleep apnea. J Oral Maxillofac Surg. 2011;69(3):687-94. & Not a systematic review \\
\hline 827 & $\begin{array}{l}\text { Liu R, Li F, Deacon SA, Li H, Chen J, Liu Z, et al. Pre-surgical orthopaedics (PSO) for infants with complete cleft lip and palate. Cochrane Database of } \\
\text { Systematic Reviews. 2015; (4). Available from: http://onlinelibrary.wiley.com/doi/10.1002/14651858.CD008868.pub2/abstract }\end{array}$ & Not a systematic review \\
\hline 828 & $\begin{array}{l}\text { Luther F, Layton S, McDonald F. Orthodontics for treating temporomandibular joint (TMJ) disorders. Cochrane Database of Systematic Reviews. 2016; } \\
\text { (1). Available from: http://onlinelibrary.wiley.com/doi/10.1002/14651858.CD006541.pub3/abstract }\end{array}$ & Not a systematic review \\
\hline 829 & $\begin{array}{l}\text { Marshall SD, Shroff B. Long-term Skeletal Changes with Rapid Maxillary Expansion: A Review of the Literature. Seminars in orthodontics. 2012;18(2):128- } \\
\text { 33. }\end{array}$ & Not a systematic review \\
\hline 830 & $\begin{array}{l}\text { Martinez-Mier EA. Fluoride-containing orthodontic adhesives may reduce the occurrence of enamel demineralization in patients with fixed orthodontic } \\
\text { appliances. Journal of Evidence-Based Dental Practice. 2011;11(3):132-4. }\end{array}$ & Not a systematic review \\
\hline 831 & $\begin{array}{l}\text { Marzooq AA, Yatabe M, Ai M. What types of occlusal factors play a role in temporomandibular disorders...? A literature review. Journal of medical and } \\
\text { dental sciences. } 1999 ; 46(3): 111-6 .\end{array}$ & Not a systematic review \\
\hline 832 & $\begin{array}{l}\text { Meursinge Reynders R, Ronchi L, Ladu L, Di Girolamo N, de Lange J, Roberts N, et al. Barriers and facilitators to the implementation of orthodontic mini- } \\
\text { implants in clinical practice: a protocol for a systematic review and meta-analysis. Systematic reviews. } 2016 ; 5: 22 \text {. }\end{array}$ & Not a systematic review \\
\hline 833 & $\begin{array}{l}\text { Nabhan AF, Abbas NH, Fleming PS, Johal A, Sadek MM. Self-ligating brackets versus conventional pre-adjusted edgewise brackets for treating } \\
\text { malocclusion. Cochrane Database of Systematic Reviews. 2016; (10). Available from: } \\
\text { http://onlinelibrary.wiley.com/doi/10.1002/14651858.CD012407/abstract }\end{array}$ & Not a systematic review \\
\hline 834 & Orthlieb JD, Giraudeau A, Laplanche O. [Occlusion and dysfunction: the paradox of dentofacial orthopedics]. L' Orthodontie francaise. 1998;69(1):69-78. & Not a systematic review \\
\hline 835 & $\begin{array}{l}\text { Perinetti G, Marsi L, Castaldo A, Contardo L. Is postural platform suited to study correlations between the masticatory system and body posture? A study } \\
\text { of repeatability and a meta-analysis of reported variations. Prog Orthod } 2012 ; 13(3): 273-80 \text {. }\end{array}$ & Not a systematic review \\
\hline 836 & $\begin{array}{l}\text { Primozic J, Perinetti G, Contardo L, Ovsenik M. Diagnostic performance of 3-dimensional evaluation of palatal vault changes in assessing successful } \\
\text { treatment of constricted maxilla in growing subjects. Am J Orthod Dentofacial Orthop 2013;143(1):42-9. }\end{array}$ & Not a systematic review \\
\hline 837 & $\begin{array}{l}\text { Quinnell TG, Clutterbuck-James AL. Alternatives to continuous positive airway pressure 2: mandibular advancement devices compared. Current opinion in } \\
\text { pulmonary medicine. } 2014 ; 20(6): 595-600 .\end{array}$ & Not a systematic review \\
\hline 838 & $\begin{array}{l}\text { Redford-Badwal DA. Individuals born with nonsyndromic oral clefts display a higher frequency of dental anomalies. The journal of evidence-based dental } \\
\text { practice. } 2012 ; 12(1): 21-3 \text {. }\end{array}$ & Not a systematic review \\
\hline 839 & $\begin{array}{l}\text { Roberts GJ, McDonald F, Neil M, Lucas VS. The Weighted Average Method 'WAM' for dental age estimation: a simpler method for children at the } 10 \text { year } \\
\text { threshold: "it is vain to do with more when less will suffice" William of Ockham 1288-1358.". Journal of forensic and legal medicine. 2014;26:56-60. }\end{array}$ & Not a systematic review \\
\hline 840 & Smith J, Bearn DR, House K. Self-ligating orthodontic braces for straightening teeth. Cochrane Database of Systematic Reviews. 2015; (4). & Not a systematic review \\
\hline 841 & $\begin{array}{l}\text { Sporniak-Tutak K, Janiszewska-Olszowska J, Kowalczyk R. Management of temporomandibular ankylosis--compromise or individualization--a literature } \\
\text { review. Medical science monitor : international medical journal of experimental and clinical research. } 2011 ; 17(5): \text { Ra111-6. }\end{array}$ & Not a systematic review \\
\hline 842 & $\begin{array}{l}\text { Strydom H, Pandis N, Katsaros C, Curatolo M, Fudalej P. Non-pharmacological interventions for alleviating pain during orthodontic treatment. Cochrane } \\
\text { Database of Systematic Reviews. 2012; (12). }\end{array}$ & Not a systematic review \\
\hline 843 & $\begin{array}{l}\text { Sujanska A, Durdik P, Rabasco J, Vitelli O, Pietropaoli N, Villa MP. SURGICAL AND NON-SURGICAL THERAPY OF OBSTRUCTIVE SLEEP APNEA } \\
\text { SYNDROME IN CHILDREN. Acta medica (Hradec Kralove). 2014;57(4):135-41. }\end{array}$ & Not a systematic review \\
\hline 844 & $\begin{array}{l}\text { Trpevska V, Kovacevska G, Benedeti A, Jordanov B. T-Scan III System diagnostic tool for digital occlusal analysis in orthodontics ? a modern approach. } \\
\text { Database of Abstracts of Reviews of Effects. 2014; (2):[155-60 pp.]. }\end{array}$ & Not a systematic review \\
\hline 845 & $\begin{array}{l}\text { Ye Q, He Y, Zou S, Zhao Z, Ren Y. Interventions for space closure in orthodontic treatment. Cochrane Database of Systematic Reviews. 2014; (12). } \\
\text { Available from: http://onlinelibrary.wiley.com/doi/10.1002/14651858.CD007671.pub3/abstract }\end{array}$ & Not a systematic review \\
\hline 846 & $\begin{array}{l}\text { Abrahamsson C, Ekberg E, Henrikson T, Bondemark L. Alterations of temporomandibular disorders before and after orthognathic surgery: a systematic } \\
\text { review. Angle Orthodontist. 2007; 77(4):[729-34 pp.]. }\end{array}$ & Published before 2012 \\
\hline 847 & $\begin{array}{l}\text { Al AZ, Gray R, Davies S, Sloan P, Glenny A. Stabilization splint therapy for the treatment of temporomandibular myofascial pain: a systematic review. } \\
\text { Journal of dental education. } 2005 ; 69(11):[1242-50 \text { pp.]. }\end{array}$ & Published before 2012 \\
\hline 848 & $\begin{array}{l}\text { Alanko O, Svedstrom-Oristo A, Tuomisto M. Patients' perceptions of orthognathic treatment, well-being, and psychological or psychiatric status: a } \\
\text { systematic review. Database of Abstracts of Reviews of Effects. 2010; (2):[249-60 pp.]. }\end{array}$ & Published before 2012 \\
\hline 849 & Aldrees AM. Lateral cephalometric norms for Saudi adults: A meta-analysis. The Saudi dental journal. 2011;23(1):3-7. & Published before 2012 \\
\hline 850 & $\begin{array}{l}\text { Al-Jewair TS, Azarpazhooh A, Suri S, Shah PS. Computer-assisted learning in orthodontic education: a systematic review and meta-analysis. Journal of } \\
\text { dental education. } 2009 ; 73(6): 730-9 \text {. }\end{array}$ & Published before 2012 \\
\hline 851 & Al-Mendalawi MD. Incidence of cleft lip and palate in Iran. A meta-analysis. Saudi medical journal. 2011;32(11):1208. & Published before 2012 \\
\hline 852 & $\begin{array}{l}\text { Al-Riyami S, Cunningham SJ, Moles DR. Orthognathic treatment and temporomandibular disorders: a systematic review. Part 2. Signs and symptoms and } \\
\text { meta-analyses. Am J Orthod Dentofacial Orthop 2009;136(5):626.e1-16, discussion -7. }\end{array}$ & Published before 2012 \\
\hline 853 & $\begin{array}{l}\text { Amaya S, Navarrete G, Barrera JP, Godoy S, Prado E, Ramírez A. Efectividad del anclaje esquelético temporal para el cierre de espacios: Revisión } \\
\text { sistemática de literatura. CES Odontol. } 2011 ; 24(2): 49-58 .\end{array}$ & Published before 2012 \\
\hline 854 & $\begin{array}{l}\text { Antonarakis G, Kiliaridis S. Short-term anteroposterior treatment effects of functional appliances and extraoral traction on class II malocclusion: a meta- } \\
\text { analysis. Angle Orthodontist. } 2007 ; 77(5):[907-14 \text { pp.]. }\end{array}$ & Published before 2012 \\
\hline 855 & $\begin{array}{l}\text { Antonarakis GS, Kiliaridis S. Maxillary molar distalization with noncompliance intramaxillary appliances in Class II malocclusion: a systematic review. } \\
\text { Angle Orthodontist. 2008; 78(6):[1133-40 pp.]. }\end{array}$ & Published before 2012 \\
\hline 856 & $\begin{array}{l}\text { Antonarakis GS, Kiliaridis S. Short-term anteroposterior treatment effects of functional appliances and extraoral traction on class II malocclusion. A meta- } \\
\text { analysis. The Angle orthodontist. 2007;77(5):907-14. }\end{array}$ & Published before 2012 \\
\hline 857 & $\begin{array}{l}\text { Badovinac RL, Shuman J, Strong E, Hayes C. Folate supplementation during pregnancy and risk for oral clefts: A meta-analysis. Journal of dental } \\
\text { research. 2003;82:B306-B. }\end{array}$ & Published before 2012 \\
\hline 858 & $\begin{array}{l}\text { Benson PE, Shah AA, Millett DT, Dyer F, Parkin N, Vine RS. Fluorides, orthodontics and demineralization: a systematic review. J Orthod 2005;32(2):102- } \\
\text { 14. }\end{array}$ & Published before 2012 \\
\hline
\end{tabular}




\begin{tabular}{|c|c|c|}
\hline 859 & $\begin{array}{l}\text { Bollen A, Cunha-Cruz J, Bakko D, Huang G, Hujoel P. The effects of orthodontic therapy on periodontal health: a systematic review of controlled evidence. } \\
\text { Journal of the American Dental Association. 2008; 139(4):[413-22 pp.]. }\end{array}$ & Published before 2012 \\
\hline 860 & $\begin{array}{l}\text { Buijs GJ, Stegenga B, Bos RR. Efficacy and safety of biodegradable osteofixation devices in oral and maxillofacial surgery: a systematic review. Journal of } \\
\text { dental research. 2006;85(11):980-9. }\end{array}$ & Published before 2012 \\
\hline 861 & $\begin{array}{l}\text { Burke SP, Silveira AM, Goldsmith LJ, Yancey JM, Van Stewart A, Scarfe WC. A meta-analysis of mandibular intercanine width in treatment and } \\
\text { postretention. The Angle orthodontist. 1998;68(1):53-60. }\end{array}$ & Published before 2012 \\
\hline 862 & Buwembo W, Luboga S. Moyer's method of mixed dentition analysis: a meta-analysis. African health sciences. 2004;4(1):63-6. & Published before 2012 \\
\hline 863 & $\begin{array}{l}\text { Callaghan A, Kendall G, Lock C, Mahony A, Payne J, Verrier L. Association between pacifier use and breast-feeding, sudden infant death syndrome, } \\
\text { infection and dental malocclusion. International journal of evidence-based healthcare. 2005;3(6):147-67. }\end{array}$ & Published before 2012 \\
\hline 864 & $\begin{array}{l}\text { Chadwick BL, Roy J, Knox J, Treasure ET. The effect of topical fluorides on decalcification in patients with fixed orthodontic appliances: a systematic } \\
\text { review. Am J Orthod Dentofacial Orthop 2005; } 128(5):[601-6 \text { pp.]. }\end{array}$ & Published before 2012 \\
\hline 865 & Chen JY, Will LA, Niederman R. Analysis of efficacy of functional appliances on mandibular growth. Am J Orthod Dentofacial Orthop 2002;122(5):470-6. & Published before 2012 \\
\hline 866 & $\begin{array}{l}\text { Chen SS, Greenlee GM, Kim JE, Smith CL, Huang GJ. Systematic review of self-ligating brackets. Am J Orthod Dentofacial Orthop 2010;137(6):726.e1- } \\
\text {.e18; discussion -7. }\end{array}$ & Published before 2012 \\
\hline 867 & $\begin{array}{l}\text { Cooper JE, Harrison JE, Worthington HV. Drug interventions for pain relief during orthodontic treatment. Cochrane Database of Systematic Reviews. } \\
2003 ; \text { (1). Available from: http://onlinelibrary.wiley.com/doi/10.1002/14651858.CD003976/abstract }\end{array}$ & Published before 2012 \\
\hline 868 & $\begin{array}{l}\text { Costa F, Robiony M, Politi M. Stability of sagittal split ramus osteotomy used to correct Class III malocclusion: review of the literature. The International } \\
\text { journal of adult orthodontics and orthognathic surgery. 2001;16(2):121-9. }\end{array}$ & Published before 2012 \\
\hline 869 & $\begin{array}{l}\text { Cozza P, Baccetti T, Franchi L, Toffol L, McNamara JA. Mandibular changes produced by functional appliances in Class II malocclusion: a systematic } \\
\text { review. Am J Orthod Dentofacial Orthop 2006; 129(5):[599.e1-.e12 pp.]. }\end{array}$ & Published before 2012 \\
\hline 870 & $\begin{array}{l}\text { Cozza P, Mucedero M, Baccetti T, Franchi L. Early orthodontic treatment of skeletal open-bite malocclusion: a systematic review. Angle Orthodontist. } \\
2005 ; 75(5):[707-13 \text { pp.]. }\end{array}$ & Published before 2012 \\
\hline 871 & $\begin{array}{l}\text { Dan AE, Thygesen TH, Pinholt EM. Corticosteroid administration in oral and orthognathic surgery: a systematic review of the literature and meta-analysis. } \\
\text { J Oral Maxillofac Surg. 2010;68(9):2207-20. }\end{array}$ & Published before 2012 \\
\hline 872 & Danda AK, Ravi P. Effectiveness of postoperative antibiotics in orthognathic surgery: a meta-analysis. J Oral Maxillofac Surg. 2011;69(10):2650-6. & Published before 2012 \\
\hline 873 & $\begin{array}{l}\text { Derks A, Katsaros C, Frencken JE, van't Hof MA, Kuijpers-Jagtman AM. Caries-inhibiting effect of preventive measures during orthodontic treatment with } \\
\text { fixed appliances. A systematic review. Caries research. 2004;38(5):413-20. }\end{array}$ & Published before 2012 \\
\hline 874 & $\begin{array}{l}\text { Fedorowicz Z, Nasser M, Newton T, Oliver R. Resorbable versus titanium plates for orthognathic surgery. Cochrane Database of Systematic Reviews. } \\
\text { 2007; (2). Available from: http://onlinelibrary.wiley.com/doi/10.1002/14651858.CD006204.pub2/abstract }\end{array}$ & Published before 2012 \\
\hline 875 & Feldmann I, Bondemark L. Orthodontic anchorage: a systematic review. The Angle orthodontist. 2006;76(3):493-501. & Published before 2012 \\
\hline 876 & $\begin{array}{l}\text { Finnema KJ, Ozcan M, Post WJ, Ren Y, Dijkstra PU. In-vitro orthodontic bond strength testing: a systematic review and meta-analysis. Am J Orthod } \\
\text { Dentofacial Orthop 2010;137(5):615-22.e3. }\end{array}$ & Published before 2012 \\
\hline 877 & Fleming PS, Johal A. Self-ligating brackets in orthodontics. A systematic review. The Angle orthodontist. 2010;80(3):575-84. & Published before 2012 \\
\hline 878 & $\begin{array}{l}\text { Fleming PS, Marinho V, Johal A. Orthodontic measurements on digital study models compared with plaster models: a systematic review. Orthodontics \& } \\
\text { craniofacial research. } 2011 ; 14(1): 1-16 \text {. }\end{array}$ & Published before 2012 \\
\hline 879 & $\begin{array}{l}\text { Flores-Mir C, Ayeh A, Goswani A, Charkhandeh S. Skeletal and dental changes in class II division } 1 \text { malocclusions treated with splint-type Herbst } \\
\text { appliances: a systematic review. Angle Orthodontist. 2007; 77(2):[376-81 pp.]. }\end{array}$ & Published before 2012 \\
\hline 880 & $\begin{array}{l}\text { Flores-Mir C, Major MP, Major PW. Soft tissue changes with fixed functional appliances in Class II division 1: a systematic review. Angle Orthodontist. } \\
\text { 2006; 76(4):[712-20 pp.]. }\end{array}$ & Published before 2012 \\
\hline 881 & $\begin{array}{l}\text { Flores-Mir C, Major P. A systematic review of cephalometric facial soft tissue changes with the Activator and Bionator appliances in Class II division } 1 \\
\text { subjects. Eur J Orthod 2006; 28(6):[586-93 pp.]. }\end{array}$ & Published before 2012 \\
\hline 882 & $\begin{array}{l}\text { Flores-Mir C, Major PW. Cephalometric facial soff tissue changes with the twin block appliance in Class II division } 1 \text { malocclusion patients. A systematic } \\
\text { review. The Angle orthodontist. 2006;76(5):876-81. }\end{array}$ & Published before 2012 \\
\hline 883 & $\begin{array}{l}\text { Flores-Mir C, Nebbe B, Major PW. Use of skeletal maturation based on hand-wrist radiographic analysis as a predictor of facial growth: a systematic } \\
\text { review. The Angle orthodontist. 2004;74(1):118-24. }\end{array}$ & Published before 2012 \\
\hline 884 & $\begin{array}{l}\text { Frazao P, Narvai PC, Latorre Mdo R, Castellanos RA. Are severe occlusal problems more frequent in permanent than deciduous dentition? Revista de } \\
\text { saude publica. 2004;38(2):247-54. }\end{array}$ & Published before 2012 \\
\hline 885 & $\begin{array}{l}\text { Fricton J, Look JO, Wright E, Alencar FG, Jr., Chen H, Lang M, et al. Systematic review and meta-analysis of randomized controlled trials evaluating } \\
\text { intraoral orthopedic appliances for temporomandibular disorders. Journal of orofacial pain. 2010;24(3):237-54. }\end{array}$ & Published before 2012 \\
\hline 886 & $\begin{array}{l}\text { Fudalej P, Dragan M, Wedrychowska-Szulc B. Prediction of the outcome of orthodontic treatment of Class III malocclusions--a systematic review. Eur J } \\
\text { Orthod 2011;33(2):190-7. }\end{array}$ & Published before 2012 \\
\hline 887 & $\begin{array}{l}\text { Gray D, Mclntyre G. Does oral health promotion influence the oral hygiene and gingival health of patients undergoing fixed ap pliance orthodontic } \\
\text { treatment? A systematic literature review. J Orthod 2008; 35(4):[262-9 pp.]. }\end{array}$ & Published before 2012 \\
\hline 888 & $\begin{array}{l}\text { Greenlee GM, Huang GJ, Chen SS, Chen J, Koepsell T, Hujoel P. Stability of treatment for anterior open-bite malocclusion: a meta-analysis. Am J Orthod } \\
\text { Dentofacial Orthop 2011;139(2):154-69. }\end{array}$ & Published before 2012 \\
\hline 889 & $\begin{array}{l}\text { Guo J, Li C, Zhang Q, Wu G, Deacon SA, Chen J, et al. Secondary bone grafting for alveolar cleft in children with cleft lip or cleft lip and palate. Cochrane } \\
\text { Database Syst Rev 2011(6):Cd008050. }\end{array}$ & Published before 2012 \\
\hline 890 & $\begin{array}{l}\text { Harrison JE, O'Brien KD, Worthington HV. Orthodontic treatment for prominent upper front teeth in children. Cochrane Database Syst Rev } \\
2007(3): C d 003452 .\end{array}$ & Published before 2012 \\
\hline 891 & Hashish DI, Mostafa YA. Effect of lip bumpers on mandibular arch dimensions. Am J Orthod Dentofacial Orthop 2009;135(1):106-9. & Published before 2012 \\
\hline 892 & $\begin{array}{l}\text { Health Quality Ontario. Oral appliances for obstructive sleep apnea: an evidence-based analysis. Database of Abstracts of Reviews of Effects. 2009; (2):[1 } \\
\text { p.]. }\end{array}$ & Published before 2012 \\
\hline 893 & $\begin{array}{l}\text { Hoekema A, Stegenga B, Bont LG. Efficacy and co-morbidity of oral appliances in the treatment of obstructive sleep apnea-hypopnea: a systematic } \\
\text { review. Critical Reviews in Oral Biology and Medicine. } 2004 ; 15(3):[137-55 \text { pp.]. }\end{array}$ & Published before 2012 \\
\hline 894 & Hunt O, Burden D, Hepper P, Johnston C. The psychosocial effects of cleft lip and palate: a systematic review. Eur J Orthod 2005;27(3):274-85. & Published before 2012 \\
\hline 895 & $\begin{array}{l}\text { Hunt OT, Johnston CD, Hepper PG, Burden DJ. The psychosocial impact of orthognathic surgery: a systematic review. Am J Orthod Dentofacial Orthop } \\
2001 ; 120(5):[490-6 \text { p.]. }\end{array}$ & Published before 2012 \\
\hline 896 & $\begin{array}{l}\text { Hutchinson K, Wellman MA, Noe DA, Kahn A. The psychosocial effects of cleft lip and palate in non-Anglo populations: a cross-cultural meta-analysis. } \\
\text { Cleft Palate Craniofac J 2011;48(5):497-508. }\end{array}$ & Published before 2012 \\
\hline 897 & $\begin{array}{l}\text { Jager A, Braumann B, Kim C, Wahner S. Skeletal and dental effects of maxillary protraction in patients with angle class III malocclusion. A meta-analysis. } \\
\text { J Orofac Orthop 2001;62(4):275-84. }\end{array}$ & Published before 2012 \\
\hline 898 & $\begin{array}{l}\text { Jayaratne Y, Zwahlen R, Lo J, Cheung L. Facial soft tissue response to anterior segmental osteotomies: a systematic review. International journal of oral } \\
\text { and maxillofacial surgery. 2010; 39(11):[1050-8. }\end{array}$ & Published before 2012 \\
\hline 899 & $\begin{array}{l}\text { Joss C, Joss-Vassalli I, Berge S, Kuijpers-Jagtman A. Soft tissue profile changes after bilateral sagittal split osteotomy for mandibular setback: a } \\
\text { systematic review. Journal of Oral and Maxillofacial Surgery. 2010;68(11):[2792-801. }\end{array}$ & Published before 2012 \\
\hline 900 & $\begin{array}{l}\text { Kaklamanos EG, Kalfas S. Meta-analysis on the effectiveness of powered toothbrushes for orthodontic patients. Am J Orthod Dentofacial Orthop } \\
2008 ; 133(2): 187 . e 1-14 \text {. }\end{array}$ & Published before 2012 \\
\hline 901 & $\begin{array}{l}\text { Kersey ML, Nebbe B, Major PW. Temporomandibular joint morphology changes with mandibular advancement surgery and rigid internal fixation: a } \\
\text { systematic literature review. The Angle orthodontist. 2003;73(1):79-85. }\end{array}$ & Published before 2012 \\
\hline 902 & Khazaei S, Shirani AM, Khazaei M, Najafi F. Incidence of cleft lip and palate in Iran. A meta-analysis. Saudi medical journal. 2011;32(4):390-3. & Published before 2012 \\
\hline 903 & $\begin{array}{l}\text { Kim JH, Viana MA, Graber TM, Omerza FF, BeGole EA. The effectiveness of protraction face mask therapy: a meta-analysis. Am J Orthod Dentofacial } \\
\text { Orthop 1999;115(6):675-85. }\end{array}$ & Published before 2012 \\
\hline 904 & Kim MR, Graber TM, Viana MA. Orthodontics and temporomandibular disorder: a meta-analysis. Am J Orthod Dentofacial Orthop 2002;121(5):438-46. & Published before 2012 \\
\hline 905 & $\begin{array}{l}\text { Koh H, Robinson PG. Occlusal adjustment for treating and preventing temporomandibular joint disorders. Cochrane database of systematic reviews } \\
\text { (Online). 2003(1). }\end{array}$ & Published before 2012 \\
\hline 906 & $\begin{array}{l}\text { Kolokitha OE, Kaklamanos EG, Papadopoulos MA. Prevalence of nickel hypersensitivity in orthodontic patients: a meta-analysis. Am J Orthod Dentofacial } \\
\text { Orthop 2008;134(6):722.e1-.e12; discussion -3. }\end{array}$ & Published before 2012 \\
\hline 907 & $\begin{array}{l}\text { Kuijpers M, Vissink A, Ren Y, Kuijpers-Jagtman A. The effect of antisialogogues in dentistry: a systematic review with a focus on bond failure in } \\
\text { orthodontics. Journal of the American Dental Association. 2010;141(8):[954-65. }\end{array}$ & Published before 2012 \\
\hline 908 & Labanauskaite B, Jankauskas G, Vasiliauskas A, Haffar N. Implants for orthodontic anchorage. Meta-analysis. Stomatologija. 2005;7(4):128-32. & Published before 2012 \\
\hline 909 & $\begin{array}{l}\text { Lagravere MO, Heo G, Major PW, Flores-Mir C. Meta-analysis of immediate changes with rapid maxillary expansion treatment. Journal of the An } \\
\text { Dental Association (1939). 2006;137(1):44-53. }\end{array}$ & Published before 2012 \\
\hline
\end{tabular}




\begin{tabular}{|c|c|c|}
\hline 910 & $\begin{array}{l}\text { Lagravere MO, Major PW, Flores-Mir C. Long-term skeletal changes with rapid maxillary expansion: a systematic review. The Angle orthodontist. } \\
\text { 2005;75(6):1046-52. }\end{array}$ & Published before 2012 \\
\hline 911 & $\begin{array}{l}\text { Lagravere MO, Major PW, Flores-Mir C. Skeletal and dental changes with fixed slow maxillary expansion treatment: a systematic review. Journal of the } \\
\text { American Dental Association (1939). 2005;136(2):194-9. }\end{array}$ & Published before 2012 \\
\hline 912 & Lee AS, Law J, Gibbon FE. Electropalatography for articulation disorders associated with cleft palate. Cochrane Database Syst Rev 2009(3):Cd006854. & Published before 2012 \\
\hline 913 & $\begin{array}{l}\text { Leonardi R, Annunziata A, Licciardello V, Barbato E. Soft tissue changes following the extraction of premolars in nongrowing patients with bimaxillary } \\
\text { protrusion: a systematic review. Angle Orthodontist. 2010;80(1):[211-6. }\end{array}$ & Published before 2012 \\
\hline 914 & $\begin{array}{l}\text { Li F, Hu HK, Chen JW, Liu ZP, Li GF, He SS, et al. Comparison of anchorage capacity between implant and headgear during anterior segment retraction. } \\
\text { The Angle orthodontist. 2011;81(5):915-22. }\end{array}$ & Published before 2012 \\
\hline 915 & $\begin{array}{l}\text { Liao YF, Mars M. Hard palate repair timing and facial growth in cleft lip and palate: a systematic review. Cleft Palate-Craniofacial Journal. 2006; } \\
43(5):[563-70 \text {. }\end{array}$ & Published before 2012 \\
\hline 916 & Lim J, Lasserson TJ, Fleetham J, Wright J. Oral appliances for obstructive sleep apnoea. Cochrane Database Syst Rev 2006(1):Cd004435. & Published before 2012 \\
\hline 917 & $\begin{array}{l}\text { Lindenmeyer A, Sutcliffe P, Eghtessad M, Goulden R, Speculand B, Harris M. Oral and maxillofacial surgery and chronic painful temporomandibular } \\
\text { disorders: a systematic review. Journal of Oral and Maxillofacial Surgery. 2010; 68(11):[2755-64. }\end{array}$ & Published before 2012 \\
\hline 918 & Littlewood S, Millett D, Doubleday B, Bearn D, Worthington H. Orthodontic retention: a systematic review. J Orthod 2006; 33(3):[205-12 pp.]. & Published before 2012 \\
\hline 919 & $\begin{array}{l}\text { Liu Z, McGrath C, Hagg U. The impact of malocclusion/orthodontic treatment need on the quality of life. A systematic review. The Angle orthodontist. } \\
\text { 2009;79(3):585-91. }\end{array}$ & Published before 2012 \\
\hline 920 & $\begin{array}{l}\text { Liu ZP, Li CJ, Hu HK, Chen JW, Li F, Zou SJ. Efficacy of short-term chincup therapy for mandibular growth retardation in Class III malocclusion. The Angle } \\
\text { orthodontist. 2011;81(1):162-68. }\end{array}$ & Published before 2012 \\
\hline 921 & $\begin{array}{l}\text { Machado E, Grehs RA, Cunali PA. Imaging from temporomandibular joint during orthodontic treatment: A systematic review. Dental Press J Orthod } \\
\text { 2011;16(3):54.e1-.e7. }\end{array}$ & Published before 2012 \\
\hline 922 & $\begin{array}{l}\text { Machado E, Machado P, Cunali PA, Grehs RA. Orthodontics as risk factor for temporomandibular disorders: A systematic review. Dental Press J Orthod } \\
\text { 2010;15(6): e.1-e.10. }\end{array}$ & Published before 2012 \\
\hline 923 & Mandall N, Millett D, Mattick C, Hickman J, Worthington H, Macfarlane T. Orthodontic adhesives: a systematic review. J Orthod 2002; 29(3):[205-10 pp.]. & Published before 2012 \\
\hline 924 & $\begin{array}{l}\text { Mandall NA, Millett DT, Mattick CR, Hickman J, Macfarlane TV, Worthington HV. Adhesives for fixed orthodontic brackets. Cochrane Database Syst Rev } \\
\text { 2003(2):Cd002282. }\end{array}$ & Published before 2012 \\
\hline 925 & $\begin{array}{l}\text { Marsico E, Gatto E, Burrascano M, Matarese G, Cordasco G. Effectiveness of orthodontic treatment with functional appliances on mandibular growth in } \\
\text { the short term. Am J Orthod Dentofacial Orthop 2011;139(1):24-36. }\end{array}$ & Published before 2012 \\
\hline 926 & $\begin{array}{l}\text { Masioli DLC, Brunharo IHVP, Noronha MdP, Moliterno LFM, Capelli Junior J, Fernandes ÁFC. Odontologia baseada em evidências: estratégia de busca } \\
\text { para o tratamento ortodôntico precoce da maloclusão Classe II de Angle. UFES rev odontol. 2005;7(1):11-7. }\end{array}$ & Published before 2012 \\
\hline 927 & $\begin{array}{l}\text { Mattheeuws N, Dermaut L, Martens G. Has hypodontia increased in Caucasians during the 20th century? A meta-analysis. Eur J Orthod 2004;26(1):99- } \\
103 .\end{array}$ & Published before 2012 \\
\hline 928 & $\begin{array}{l}\text { Mattos CT, Vilani GN, Sant'Anna EF, Ruellas AC, Maia LC. Effects of orthognathic surgery on oropharyngeal airway: a meta-analysis. International journal } \\
\text { of oral and maxillofacial surgery. 2011;40(12):1347-56. }\end{array}$ & Published before 2012 \\
\hline 929 & $\begin{array}{l}\text { Miles PG, Vig PS, Weyant RJ, Forrest TD, Rockette HE. Craniofacial structure and obstructive sleep apnea syndrome - A qualitative analysis and meta- } \\
\text { analysis of the literature. Am J Orthod Dentofacial Orthop 1996;109(2):163-72. }\end{array}$ & Published before 2012 \\
\hline 930 & $\begin{array}{l}\text { Millett D, Mandall N, Hickman J, Mattick R, Glenny AM. Adhesives for fixed orthodontic bands. A systematic review. The Angle orthodontist. } \\
\text { 2009;79(1):193-9. }\end{array}$ & Published before 2012 \\
\hline 931 & $\begin{array}{l}\text { Millett DT, Cunningham S, O'Brien KD, Benson PE, Williams A, de OCM. Orthodontic treatment for deep bite and retroclined upper front teeth in children. } \\
\text { Cochrane Database of Systematic Reviews. 2006; (4). Available from: http://onlinelibrary.wiley.com/doi/10.1002/14651858.CD005972.pub2/abstract }\end{array}$ & Published before 2012 \\
\hline 932 & $\begin{array}{l}\text { Millett DT, Mandall NA, Mattick RC, Hickman J, Glenny AM. Adhesives for bonded molar tubes during fixed brace treatment. Cochrane Database Syst Rev } \\
\text { 2011(6):Cd008236. }\end{array}$ & Published before 2012 \\
\hline 933 & Mills JR. The effect of functional appliances on the skeletal pattern. Br J Orthod 1991;18(4):267-75. & Published before 2012 \\
\hline 934 & $\begin{array}{l}\text { Moore NL. Suffer the little children: fixed intraoral habit appliances for treating childhood thumbsucking habits: a critical review of the literature. Int J } \\
\text { Orofcal Myol 2002;28:6-38. }\end{array}$ & Published before 2012 \\
\hline 935 & $\begin{array}{l}\text { Mucedero M, Coviello A, Baccetti T, Franchi L, Cozza P. Stability factors after double-jaw surgery in Class III malocclusion. A systematic review. The } \\
\text { Angle orthodontist. 2008;78(6):1141-52. }\end{array}$ & Published before 2012 \\
\hline 936 & $\begin{array}{l}\text { Naoumova J, Kurol J, Kjellberg H. A systematic review of the interceptive treatment of palatally displaced maxillary canines. Eur J Orthod 2011; } \\
33(2):[143-9 \text { pp.]. }\end{array}$ & Published before 2012 \\
\hline 937 & $\begin{array}{l}\text { Ng J, Major PW, Heo G, Flores-Mir C. True incisor intrusion attained during orthodontic treatment: a systematic review and meta-analysis. Am J Orthod } \\
\text { Dentofacial Orthop 2005;128(2):212-9. }\end{array}$ & Published before 2012 \\
\hline 938 & $\begin{array}{l}\text { Nguyen QV, Bezemer PD, Habets L, Prahl-Andersen B. A systematic review of the relationship between overjet size and traumatic dental injuries. Eur J } \\
\text { Orthod 1999;21(5):503-15. }\end{array}$ & Published before 2012 \\
\hline 939 & $\begin{array}{l}\text { Niu Y, Zhou H. [Effect on functional appliances on mandibular growth on skeletal Class II malocclusion: a systematic review]. Hua xi kou qiang yi xue za } \\
\text { zhi = Huaxi kouqiang yixue zazhi = West China journal of stomatology. 2011;29(4):384-8. }\end{array}$ & Published before 2012 \\
\hline 940 & $\begin{array}{l}\text { Nollet PJ, Katsaros C, Van't Hof MA, Kuijpers-Jagtman AM. Treatment outcome in unilateral cleft lip and palate evaluated with the GOSLON yardstick: a } \\
\text { meta-analysis of } 1236 \text { patients. Plastic and reconstructive surgery. } 2005 ; 116(5): 1255-62 \text {. }\end{array}$ & Published before 2012 \\
\hline 941 & Ohashi E, Pecho OE, Moron M, Lagravere MO.I. Angle Orthodontist. 2006; 76(4):[721-7. & Published before 2012 \\
\hline 942 & Papadopoulos MA, Chatzoudi M, Kaklamanos EG. Prevalence of tooth transposition. A meta-analysis. The Angle orthodontist. 2010;80(2):275-85. & Published before 2012 \\
\hline 943 & $\begin{array}{l}\text { Papadopoulos MA, Chatzoudi M, Karagiannis V. Assessment of characteristic features and dental anomalies accompanying tooth transposition: a meta- } \\
\text { analysis. Am J Orthod Dentofacial Orthop 2009;136(3):308.e1-10; discussion -9. }\end{array}$ & Published before 2012 \\
\hline 944 & $\begin{array}{l}\text { Papadopoulos MA, Papageorgiou SN, Zogakis IP. Clinical effectiveness of orthodontic miniscrew implants: a meta-analysis. Journal of dental research. } \\
\text { 2011;90(8):969-76. }\end{array}$ & Published before 2012 \\
\hline 945 & $\begin{array}{l}\text { Parkin N, Benson PE, Thind B, Shah A. Open versus closed surgical exposure of canine teeth that are displaced in the roof of the mouth. Cochrane } \\
\text { Database of Systematic Reviews. 2008; (4). }\end{array}$ & Published before 2012 \\
\hline 946 & $\begin{array}{l}\text { Perillo L, Cannavale R, Ferro F, Franchi L, Masucci C, Chiodini P, et al. Meta-analysis of skeletal mandibular changes during Frankel appliance treatment. } \\
\text { Eur J Orthod 2011;33(1):84-92. }\end{array}$ & Published before 2012 \\
\hline 947 & $\begin{array}{l}\text { Petren S, Bondemark L, Soderfeldt B. A systematic review concerning early orthodontic treatment of unilateral posterior crossbite. The Angle orthodontist. } \\
2003 ; 73(5): 588-96 \text {. }\end{array}$ & Published before 2012 \\
\hline 948 & $\begin{array}{l}\text { Polder BJ, Van't Hof MA, Van der Linden FP, Kuijpers-Jagtman AM. A meta-analysis of the prevalence of dental agenesis of permanent teeth. Community } \\
\text { dentistry and oral epidemiology. 2004;32(3):217-26. }\end{array}$ & Published before 2012 \\
\hline 949 & $\begin{array}{l}\text { Popowich K, Nebbe B, Major PW. Effect of Herbst treatment on temporomandibular joint morphology: a systematic literature review. Am J Orthod } \\
\text { Dentofacial Orthop 2003;123(4):388-94. }\end{array}$ & Published before 2012 \\
\hline 950 & $\begin{array}{l}\text { Ren Y, Maltha JC, Kuijpers-Jagtman AM. Optimum force magnitude for orthodontic tooth movement: a systematic literature review. The Angle } \\
\text { orthodontist. 2003;73(1):86-92. }\end{array}$ & Published before 2012 \\
\hline 951 & $\begin{array}{l}\text { Reynders R, Ronchi L, Bipat S. Mini-implants in orthodontics: a systematic review of the literature. Am J Orthod Dentofacial Orthop 2009; 135(5):564.e1- } \\
\text { e19. }\end{array}$ & Published before 2012 \\
\hline 952 & Riley M, Bearn DR. A systematic review of clinical trials of aligning archwires. J Orthod 2009;36(1):42-51; discussion 15. & Published before 2012 \\
\hline 953 & Rinchuse DJ, Kandasamy S. Articulators in orthodontics: An evidence-based perspective. Am J Orthod Dentofacial Orthop 2006;129(2):299-308. & Published before 2012 \\
\hline 954 & $\begin{array}{l}\text { Robinson PG, Deacon SA, Deery C, Heanue M, Walmsley AD, Worthington HV, et al. Manual versus powered toothbrushing for oral health. Cochrane } \\
\text { Database of Systematic Reviews. 2005(2). }\end{array}$ & Published before 2012 \\
\hline 955 & $\begin{array}{l}\text { Rogers S, Chadwick B, Treasure E. Fluoride-containing orthodontic adhesives and decalcification in patients with fixed appliances: a systematic review. } \\
\text { Am J Orthod Dentofacial Orthop 2010;138(4):[390.e1-.e8. }\end{array}$ & Published before 2012 \\
\hline 956 & $\begin{array}{l}\text { Rotundo R, Nieri M, lachetti G, Mervelt J, Cairo F, Baccetti T, et al. Orthodontic treatment of periodontal defects. A systematic review. Prog Orthod } \\
\text { 2010;11(1):41-4. }\end{array}$ & Published before 2012 \\
\hline 957 & $\begin{array}{l}\text { Sacchetto L, Berzaghi A, Martinolli M, Bortolini S. Timing of treatment and the concept of urgency in orthodontics. Guidelines and review of the literature. } \\
\text { Dental Cadmos. } 2011 ; 79(9): 620-8 \text {. }\end{array}$ & Published before 2012 \\
\hline 958 & $\begin{array}{l}\text { Schatzle M, Mannchen R; Zwahlen M, Lang NP. Survival and failure rates of orthodontic temporary anchorage devices: a systematic review. Clinical oral } \\
\text { implants research. 2009;20(12):1351-9. }\end{array}$ & Published before 2012 \\
\hline 959 & Schiffman PH, Tuncay OC. Maxillary expansion: a meta analysis. Clinical orthodontics and research. 2001;4(2):86-96. & Published before 2012 \\
\hline 960 & $\begin{array}{l}\text { Schmidt-Nowara W, Lowe A, Wiegand L, Cartwright R, Perez-Guerra F, Menn S. Oral appliances for the treatment of snoring and obstructive sleep apnea: } \\
\text { a review. Sleep. 1995; 18(6):[501-10. }\end{array}$ & Published before 2012 \\
\hline
\end{tabular}




\begin{tabular}{|c|c|c|}
\hline 961 & $\begin{array}{l}\text { Segal GR, Schiffman PH, Tuncay OC. Meta analysis of the treatment-related factors of external apical root resorption. Orthodontics \& craniofacial } \\
\text { research. } 2004 ; 7(2): 71-8 .\end{array}$ & Published before 2012 \\
\hline 962 & Shaw WC, Mandall NA, Mattick CR. Ethical and scientific decision making in distraction osteogenesis. Cleft Palate Craniofac J 2002;39(6):641-5. & Published before 2012 \\
\hline 963 & $\begin{array}{l}\text { Skeggs RM, Benson PE, Dyer F. Reinforcement of anchorage during orthodontic brace treatment with implants or other surgical methods. Cochrane } \\
\text { Database Syst Rev 2007(3):Cd005098. }\end{array}$ & Published before 2012 \\
\hline 964 & $\begin{array}{l}\text { Tan SK, Lo J, Zwahlen RA. Perioperative antibiotic prophylaxis in orthognathic surgery: a systematic review and meta-analysis of clinical trials. Oral } \\
\text { surgery, oral medicine, oral pathology, oral radiology, and endodontics. } 2011 ; 112(1): 19-27 \text {. }\end{array}$ & Published before 2012 \\
\hline 965 & $\begin{array}{l}\text { Toffol LD, Pavoni C, Baccetti T, Franchi L, Cozza P. Orthopedic treatment outcomes in Class III malocclusion: a systematic review. Angle Orthodontist. } \\
2008 ; 78(3):[561-73 \text { pp.]. }\end{array}$ & Published before 2012 \\
\hline 966 & $\begin{array}{l}\text { Tsukiyama Y, Baba K, Clark GT. An evidence-based assessment of occlusal adjustment as a treatment for temporomandibular disorders. Journal of } \\
\text { Prosthetic Dentistry. } 2001 ; 86(1): 57-66 \text {. }\end{array}$ & Published before 2012 \\
\hline 967 & $\begin{array}{l}\text { Uzel A, Alparslan Z. Long-term effects of presurgical infant orthopedics in patients with cleft lip and palate: a systematic review. Cleft Palate-Craniofacial } \\
\text { Journal. } 2011 ; 48(5):[587-95 .\end{array}$ & Published before 2012 \\
\hline 968 & $\begin{array}{l}\text { Verstraaten J, Kuijpers-Jagtman A, Mommaerts M, Berge S, Nada R, Schols J. A systematic review of the effects of bone-borne surgical assisted rapid } \\
\text { maxillary expansion. Journal of Cranio-Maxillo-Facial Surgery. 2010; 38(3):[166-74. }\end{array}$ & Published before 2012 \\
\hline 969 & $\begin{array}{l}\text { von Bohl M, Kuijpers-Jagtman AM. Hyalinization during orthodontic tooth movement: a systematic review on tissue reactions. Eur J Orthod 2009;31(1):30- } \\
6 .\end{array}$ & Published before 2012 \\
\hline 970 & $\begin{array}{l}\text { Weinberg SM, Maher BS, Marazita ML. Parental craniofacial morphology in cleft lip with or without cleft palate as determined by cephalometry: a meta- } \\
\text { analysis. Orthodontics \& craniofacial research. 2006;9(1):18-30. }\end{array}$ & Published before 2012 \\
\hline 971 & $\begin{array}{l}\text { Xiaoting L, Yin T, Yangxi C. Interventions for pain during fixed orthodontic appliance therapy. A systematic review. The Angle orthodontist. } \\
\text { 2010;80(5):925-32. }\end{array}$ & Published before 2012 \\
\hline 972 & $\begin{array}{l}\text { Zhang M, McGrath C, Hägg U. The impact of malocclusion and its treatment on quality of life: A literature review. International journal of paediatric } \\
\text { dentistry. 2006;16(6):381-7. }\end{array}$ & Published before 2012 \\
\hline 973 & $\begin{array}{l}\text { Nasser M, Fedorowicz Z, Newton T, Nouri M. Interventions for the management of submucous cleft palate. Cochrane Database of Systematic Reviews. } \\
2016 ; \text { (1). }\end{array}$ & Withdrawn review \\
\hline 974 & $\begin{array}{l}\text { Elkordy SA, Aboelnaga AA, Fayed MM, AboulFotouh MH, Abouelezz AM. Can the use of skeletal anchors in conjunction with fixed functional appliances } \\
\text { promote skeletal changes? A systematic review and meta-analysis. Eur J Orthod } 2016 ; 38(5): 532-45 .\end{array}$ & Registered in other register \\
\hline 975 & Roscoe MG. Reabsorção radicular inflamatória induzida ortodonticamente: revisão sistemática e análise por elementos finitos. 2015:112-. & Duplicate review \\
\hline 1088 & Marquezan M. Associação entre a estabilidade primária de mini-implantes ortodônticos e a qualidade dos substratos ósseos receptores. 2013:132-. & Published as thesis \\
\hline 977 & $\begin{array}{l}\text { Agostino P, Ugolini A, Signori A, Silvestrini-Biavati A, Harrison JE, Riley P. Orthodontic treatment for posterior crossbites. Cochrane Database Syst Rev } \\
\text { 2014(8):Cd000979. }\end{array}$ & Cochrane review \\
\hline 978 & $\begin{array}{l}\text { Ahangari Z, Nasser M, Mahdian M, Fedorowicz Z, Marchesan MA. Interventions for the management of external root resorption. Cochrane Database of } \\
\text { Systematic Reviews. 2015; (11). }\end{array}$ & Cochrane review \\
\hline 997 & $\begin{array}{l}\text { Benson PE, Parkin N, Dyer F, Millett DT, Furness S, Germain P. Fluorides for the prevention of early tooth decay (demineralised white lesions) during } \\
\text { fixed brace treatment. Cochrane Database Syst Rev 2013(12):Cd003809. }\end{array}$ & Cochrane review \\
\hline 1006 & $\begin{array}{l}\text { Carvalho FR, Lentini-Oliveira DA, Prado LB, Prado GF, Carvalho LB. Oral appliances and functional orthopaedic appliances for obstructive sleep apnoea } \\
\text { in children. Cochrane Database of Systematic Reviews. 2016; (10). }\end{array}$ & Cochrane review \\
\hline 1017 & $\begin{array}{l}\text { El-Angbawi A, Mclntyre GT, Fleming PS, Bearn DR. Non-surgical adjunctive interventions for accelerating tooth movement in patients undergoing fixed } \\
\text { orthodontic treatment. Cochrane Database of Systematic Reviews. 2015; (11). }\end{array}$ & Cochrane review \\
\hline 1025 & $\begin{array}{l}\text { Fleming PS, Fedorowicz Z, Johal A, El-Angbawi A, Pandis N. Surgical adjunctive procedures for accelerating orthodontic treatment. Cochrane Database } \\
\text { Syst Rev 2015(6):Cd010572. }\end{array}$ & Cochrane review \\
\hline 1045 & $\mathrm{Hu} \mathrm{H,} \mathrm{Li} \mathrm{C,} \mathrm{Li} \mathrm{F,} \mathrm{Chen} \mathrm{J,} \mathrm{Sun} \mathrm{J,} \mathrm{Zou} \mathrm{S,} \mathrm{et} \mathrm{al.} \mathrm{Enamel} \mathrm{etching} \mathrm{for} \mathrm{bonding} \mathrm{fixed} \mathrm{orthodontic} \mathrm{braces.} \mathrm{Cochrane} \mathrm{Database} \mathrm{Syst} \mathrm{Rev} \mathrm{2013(11):Cd005516.}$ & Cochrane review \\
\hline 1052 & $\begin{array}{l}\text { Jambi S, Thiruvenkatachari B, O'Brien KD, Walsh T. Orthodontic treatment for distalising upper first molars in children and adolescents. Cochrane } \\
\text { Database Syst Rev 2013(10):Cd008375. }\end{array}$ & Cochrane review \\
\hline 1053 & $\begin{array}{l}\text { Jambi S, Walsh T, Sandler J, Benson PE, Skeggs RM, O'Brien KD. Reinforcement of anchorage during orthodontic brace treatment with implants or other } \\
\text { surgical methods. Cochrane Database Syst Rev 2014(8):Cd005098. }\end{array}$ & Cochrane review \\
\hline 1059 & $\begin{array}{l}\text { Jian F, Lai W, Furness S, McIntyre GT, Millett DT, Hickman J, et al. Initial arch wires for tooth alignment during orthodontic treatment with fixed appliances. } \\
\text { Cochrane Database Syst Rev 2013(4):Cd007859. }\end{array}$ & Cochrane review \\
\hline 1066 & $\begin{array}{l}\text { Kloukos D, Fudalej P, Sequeira-Byron P, Katsaros C. Maxillary distraction osteogenesis versus orthognathic surgery for cleft lip and palate patients. } \\
\text { Cochrane Database of Systematic Reviews. 2016; (9). }\end{array}$ & Cochrane review \\
\hline 1073 & $\begin{array}{l}\text { Lentini-Oliveira DA, Carvalho FR, Rodrigues CG, Ye Q, Prado LB, Prado GF, et al. Orthodontic and orthopaedic treatment for anterior open bite in } \\
\text { children. Cochrane Database Syst Rev 2014(9):Cd005515. }\end{array}$ & Cochrane review \\
\hline 1077 & $\begin{array}{l}\text { Littlewood SJ, Millett DT, Doubleday B, Bearn DR, Worthington HV. Retention procedures for stabilising tooth position after treatment with orthodontic } \\
\text { braces. Cochrane Database of Systematic Reviews. 2016; (1). }\end{array}$ & Cochrane review \\
\hline 1096 & Millett DT, Glenny AM, Mattick CR, Hickman J, Mandall NA. Adhesives for fixed orthodontic bands. Cochrane Database Syst Rev $2016(3):$ Cd004485. & Cochrane review \\
\hline 1097 & $\begin{array}{l}\text { Minami-Sugaya H, Lentini-Oliveira DA, Carvalho FR, Machado MA, Marzola C, Saconato H, et al. Treatments for adults with prominent lower front teeth. } \\
\text { Cochrane Database Syst Rev 2012(5):Cd006963. }\end{array}$ & Cochrane review \\
\hline 1147 & $\begin{array}{l}\text { Thiruvenkatachari B, Harrison JE, Worthington HV, O'Brien KD. Orthodontic treatment for prominent upper front teeth (Class II malocclusion) in children. } \\
\text { Cochrane Database Syst Rev 2013(11):Cd003452. }\end{array}$ & Cochrane review \\
\hline 1159 & $\begin{array}{l}\text { Watkinson S, Harrison JE, Furness S, Worthington HV. Orthodontic treatment for prominent lower front teeth (Class III malocclusion) in children. Cochrane } \\
\text { Database Syst Rev 2013(9):Cd003451. }\end{array}$ & Cochrane review \\
\hline 1167 & $\begin{array}{l}\text { Yu Y, Sun J, Lai W, Wu T, Koshy S, Shi Z. Interventions for managing relapse of the lower front teeth after orthodontic treatment. Cochrane Database of } \\
\text { Systematic Reviews. 2013; (9). }\end{array}$ & Cochrane review \\
\hline $\mathrm{Nr}$ & Paper & Status \\
\hline 976 & Abbott M, Meara J. Nasoalveolar molding in cleft care: is it efficacious?. Plastic and reconstructive surgery. 2012; 130(3):[659-66 pp.]. & Included \\
\hline 979 & $\begin{array}{l}\text { Akbari M, Lankarani KB, Honarvar B, Tabrizi R, Mirhadi H, Moosazadeh M. Prevalence of malocclusion among Iranian children: A systematic review and } \\
\text { meta-analysis. Dental research journal. 2016;13(5):387-95. }\end{array}$ & Included \\
\hline 980 & $\begin{array}{l}\text { Alfawal AM, Hajeer MY, Ajaj MA, Hamadah O, Brad B. Effectiveness of minimally invasive surgical procedures in the acceleration of tooth movement: a } \\
\text { systematic review and meta-analysis. Prog Orthod } 2016 ; 17(1): 33 \text {. }\end{array}$ & Included \\
\hline 981 & $\begin{array}{l}\text { Aljabaa A, McDonald F, Newton J. A systematic review of randomized controlled trials of interventions to improve adherence among orthodontic patients } \\
\text { aged } 12 \text { to } 18 \text {. Database of Abstracts of Reviews of Effects. 2014; (2):[epub. }\end{array}$ & Included \\
\hline 982 & $\begin{array}{l}\text { Al-Jewair TS. Meta-analysis on the mandibular dimensions effects of the MARA appliance in patients with Class II malocclusions. The Angle orthodontist. } \\
2015 ; 85(4): 706-14 \text {. }\end{array}$ & Included \\
\hline 983 & Al-Moghrabi D, Pandis N, Fleming PS. The effects of fixed and removable orthodontic retainers: a systematic review. Prog Orthod 2016;17(1):24. & Included \\
\hline 984 & $\begin{array}{l}\text { Al-Moraissi EA, Al-Magaleh SM, Iskandar RA, Al-Hendi EA. Impact on the pharyngeal airway space of different orthognathic procedures for the prognathic } \\
\text { mandible. International journal of oral and maxillofacial surgery. } 2015 ; 44(9): 1110-8 \text {. }\end{array}$ & Included \\
\hline 985 & $\begin{array}{l}\text { Al-Moraissi EA, Wolford LM. Does Temporomandibular Joint Pathology With or Without Surgical Management Affect the Stability of Counterclockwise } \\
\text { Rotation of the Maxillomandibular Complex in Orthognathic Surgery? A Systematic Review and Meta-Analysis. J Oral Maxillofac Surg. } 2016 .\end{array}$ & Included \\
\hline 986 & $\begin{array}{l}\text { Al-Moraissi EA, Wolford LM. Is Counterclockwise Rotation of the Maxillomandibular Complex Stable Compared With Clockwise Rotation in the Correction } \\
\text { of Dentofacial Deformities? A Systematic Review and Meta-Analysis. J Oral Maxillofac Surg. 2016;74(10):2066.e1-.e12. }\end{array}$ & Included \\
\hline 987 & $\begin{array}{l}\text { Almpani K, Papageorgiou SN, Papadopoulos MA. Autotransplantation of teeth in humans: a systematic review and meta-analysis. Clinical oral } \\
\text { investigations. } 2015 ; 19(6): 1157-79 \text {. }\end{array}$ & Included \\
\hline 988 & $\begin{array}{l}\text { Alsafadi AS, Alabdullah MM, Saltaji H, Abdo A, Youssef M. Effect of molar intrusion with temporary anchorage devices in patients with anterior open bite: } \\
\text { a systematic review. Prog Orthod 2016;17:9. }\end{array}$ & Included \\
\hline 989 & $\begin{array}{l}\text { Altmann AS, Collares FM, Leitune VC, Samuel SM. The effect of antimicrobial agents on bond strength of orthodontic adhesives: a meta-analysis of in } \\
\text { vitro studies. Orthodontics \& craniofacial research. 2016;19(1):1-9. }\end{array}$ & Included \\
\hline 990 & $\begin{array}{l}\text { Andiappan M, Gao W, Bernabe E, Kandala NB, Donaldson AN. Malocclusion, orthodontic treatment, and the Oral Health Impact Profile (OHIP-14): } \\
\text { Systematic review and meta-analysis. The Angle orthodontist. 2015;85(3):493-500. }\end{array}$ & Included \\
\hline 991 & $\begin{array}{l}\text { Andrade D, Loureiro C, Araujo V, Riera R, Atallah A. Treatment for agenesis of maxillary lateral incisors: a systematic review. Database of Abstracts of } \\
\text { Reviews of Effects. 2013; (2):[129-36. }\end{array}$ & Included \\
\hline 992 & $\begin{array}{l}\text { Angelopoulou MV, Vlachou V, Halazonetis DJ. Pharmacological management of pain during orthodontic treatment: a meta-analysis. Orthodontics \& } \\
\text { craniofacial research. } 2012 ; 15(2): 71-83 \text {. }\end{array}$ & Included \\
\hline
\end{tabular}




\begin{tabular}{|c|c|c|}
\hline 993 & $\begin{array}{l}\text { Arnold S, Koletsi D, Patcas R, Eliades T. The effect of bracket ligation on the periodontal status of adolescents undergoing orthodontic treatment. A } \\
\text { systematic review and meta-analysis. Journal of dentistry. 2016;54:13-24. }\end{array}$ & Included \\
\hline 994 & $\begin{array}{l}\text { Ata-Ali F, Ata-Ali J, Ferrer-Molina M, Cobo T, De Carlos F, Cobo J. Adverse effects of lingual and buccal orthodontic techniques: A systematic review and } \\
\text { meta-analysis. Am J Orthod Dentofacial Orthop 2016;149(6):820-9. }\end{array}$ & Included \\
\hline 995 & $\begin{array}{l}\text { Atala-Acevedo C, Abarca J, Martinez-Zapata MJ, Diaz J, Olate S, Zaror C. Success Rate of Autotransplantation of Teeth With an Open Apex: Systematic } \\
\text { Review and Meta-Analysis. J Oral Maxillofac Surg. 2016. }\end{array}$ & Included \\
\hline 996 & $\begin{array}{l}\text { Austin S, Mattick C, Waterhouse P. Distraction osteogenesis versus orthognathic surgery for the treatment of maxillary hypoplasia in cleft lip and palate } \\
\text { patients: a systematic review. Database of Abstracts of Reviews of Effects. 2014; (2):[epub. }\end{array}$ & Included \\
\hline 998 & $\begin{array}{l}\text { Bichara LM, Araujo RC, Flores-Mir C, Normando D. Impact of primary palatoplasty on the maxillomandibular sagittal relationship in patients with unilateral } \\
\text { cleft lip and palate: a systematic review and meta-analysis. International journal of oral and maxillofacial surgery. } 2015 ; 44(1): 50-6 \text {. }\end{array}$ & Included \\
\hline 999 & $\begin{array}{l}\text { Bock NC, von Bremen J, Ruf S. Stability of Class II fixed functional appliance therapy--a systematic review and meta-analysis. Eur J Orthod } \\
2016 ; 38(2): 129-39 \text {. }\end{array}$ & Included \\
\hline 1000 & $\begin{array}{l}\text { Bohl M, Ren Y, Fudalej P, Kuijpers-Jagtman A. Pulpal reactions to orthodontic force application in humans: a systematic review. Journal of endodontics. } \\
\text { 2012; 38(11):[1463-9. }\end{array}$ & Included \\
\hline 1001 & $\begin{array}{l}\text { Brons S, van Beusichem ME, Bronkhorst EM, Draaisma J, Berge SJ, Maal TJ, et al. Methods to quantify soft-tissue based facial growth and treatment } \\
\text { outcomes in children: a systematic review. PloS one. 2012;7(8):e41898. }\end{array}$ & Included \\
\hline 1002 & $\begin{array}{l}\text { Brons S, van Beusichem ME, Bronkhorst EM, Draaisma JM, Berge SJ, Schols JG, et al. Methods to quantify soft tissue-based cranial growth and } \\
\text { treatment outcomes in children: a systematic review. PloS one. 2014;9(2):e89602. }\end{array}$ & Included \\
\hline 1003 & $\begin{array}{l}\text { Buck LM, Dalci O, Darendeliler MA, Papadopoulou AK. Effect of Surgically Assisted Rapid Maxillary Expansion on Upper Airway Volume: A Systematic } \\
\text { Review. J Oral Maxillofac Surg. 2016;74(5):1025-43. }\end{array}$ & Included \\
\hline 1004 & $\begin{array}{l}\text { Buck LM, Dalci O, Darendeliler MA, Papageorgiou SN, Papadopoulou AK. Volumetric upper airway changes after rapid maxillary expansion: a systematic } \\
\text { review and meta-analysis. Eur J Orthod } 2016 \text {. }\end{array}$ & Included \\
\hline 1005 & $\begin{array}{l}\text { Buzatta LN, Shimizu RH, Shimizu IA, Pacheco-Pereira C, Flores-Mir C, Taba M, Jr., et al. Gingival condition associated with two types of orthodontic fixed } \\
\text { retainers: a meta-analysis. Eur J Orthod } 2016 \text {. }\end{array}$ & Included \\
\hline 1007 & $\begin{array}{l}\text { Celar A, Schedlberger M, Dorfler P, Bertl M. Systematic review on self-ligating vs. conventional brackets: initial pain, number of visits, treatment time. J } \\
\text { Orofac Orthop 2013;74(1):40-51. }\end{array}$ & Included \\
\hline 1008 & $\begin{array}{l}\text { Chatzoudi MI, loannidou-Marathiotou I, Papadopoulos MA. Clinical effectiveness of chin cup treatment for the management of Class III malocclusion in } \\
\text { pre-pubertal patients: a systematic review and meta-analysis. Prog Orthod 2014;15:62. }\end{array}$ & Included \\
\hline 1009 & $\begin{array}{l}\text { Cheng HC, Wang YC, Tam KW, Yen MF. Effects of tooth extraction on smile esthetics and the buccal corridor: A meta-analysis. Journal of Dental } \\
\text { Sciences. } 2016 \text {. }\end{array}$ & Included \\
\hline 1010 & $\begin{array}{l}\text { Christovam IO, Lisboa CO, Ferreira DM, Cury-Saramago AA, Mattos CT. Upper airway dimensions in patients undergoing orthognathic surgery: a } \\
\text { systematic review and meta-analysis. International journal of oral and maxillofacial surgery. 2016;45(4):460-71. }\end{array}$ & Included \\
\hline 1011 & $\begin{array}{l}\text { Cordasco G, Matarese G, Rustico L, Fastuca S, Caprioglio A, Lindauer SJ, et al. Efficacy of orthopedic treatment with protraction facemask on skeletal } \\
\text { Class III malocclusion: a systematic review and meta-analysis. Orthodontics \& craniofacial research. } 2014 ; 17(3): 133-43 \text {. }\end{array}$ & Included \\
\hline 1012 & $\begin{array}{l}\text { Correa Cde C, Bueno Mda R, Lauris JR, Berretin-Felix G. Interference of conventional and orthodontic nipples in system stomatognatic: systematic } \\
\text { review. CoDAS. 2016;28(2):182-9. }\end{array}$ & Included \\
\hline 1013 & $\begin{array}{l}\text { Dalessandri D, Salgarello S, Dalessandri M, Lazzaroni E, Piancino M, Paganelli C, et al. Determinants for success rates of temporary anchorage devices } \\
\text { in orthodontics: a meta-analysis }(n>50) \text {. Eur J Orthod 2014;36(3):303-13. }\end{array}$ & Included \\
\hline 1014 & $\begin{array}{l}\text { de Almeida VL, de Andrade Gois VL, Andrade RN, Cesar CP, de Albuquerque-Junior RL, de Mello Rode S, et al. Efficiency of low-level laser therapy } \\
\text { within induced dental movement: A systematic review and meta-analysis. Journal of photochemistry and photobiology B, Biology. 2016;158:258-66. }\end{array}$ & Included \\
\hline 1015 & $\begin{array}{l}\text { Diar-Bakirly S, Feres MF, Saltaji H, Flores-Mir C, El-Bialy T. Effectiveness of the transpalatal arch in controlling orthodontic anchorage in maxillary } \\
\text { premolar extraction cases: A systematic review and meta-analysis. The Angle orthodontist. } 2016 .\end{array}$ & Included \\
\hline 1016 & $\begin{array}{l}\text { Ehsani S, Nebbe B, Normando D, Lagravere MO, Flores-Mir C. Short-term treatment effects produced by the Twin-block appliance: a systematic review } \\
\text { and meta-analysis. Eur J Orthod 2015;37(2):170-6. }\end{array}$ & Included \\
\hline 1018 & $\begin{array}{l}\text { Fang J, Li Y, Zhang K, Zhao Z, Mei L. Escaping the Adverse Impacts of NSAIDs on Tooth Movement During Orthodontics: Current Evidence Based on a } \\
\text { Meta-Analysis. Medicine. 2016;95(16):e3256. }\end{array}$ & Included \\
\hline 1019 & $\begin{array}{l}\text { Feng X, Li J, Li Y, Zhao Z, Zhao S, Wang J. Effectiveness of TAD-anchored maxillary protraction in late mixed dentition. The Angle orthodontist. } \\
2012 ; 82(6): 1107-14 \text {. }\end{array}$ & Included \\
\hline 1020 & $\begin{array}{l}\text { Feres MF, Abreu LG, Insabralde NM, de Almeida MR, Flores-Mir C. Effectiveness of open bite correction when managing deleterious oral habits in } \\
\text { growing children and adolescents: a systematic review and meta-analysis. Eur J Orthod } 2016 .\end{array}$ & Included \\
\hline 1021 & $\begin{array}{l}\text { Fernández-Ferrer L, Montiel-Company JM, Pinho T, Almerich-Silla JM, Bellot-Arcís C. Effects of mandibular setback surgery on upper airway dimensions } \\
\text { and their influence on obstructive sleep apnoea - A systematic review. Journal of Cranio-Maxillofacial Surgery. 2015;43(2):248-53. }\end{array}$ & Included \\
\hline 1022 & $\begin{array}{l}\text { Filho H, Maia L, Lau T, Souza M, Maia L. Early vs late orthodontic treatment of tooth crowding by first premolar extraction: a systematic review. Database } \\
\text { of Abstracts of Reviews of Effects. 2014; (2):[epub. }\end{array}$ & Included \\
\hline 1023 & $\begin{array}{l}\text { Fleming P, Johal A, Pandis N. The effectiveness of laceback ligatures during initial orthodontic alignment: a systematic review and meta-analysis. } \\
\text { Database of Abstracts of Reviews of Effects. 2013; (2):[539-46. }\end{array}$ & Included \\
\hline 1024 & $\begin{array}{l}\text { Fleming PS, Eliades T, Katsaros C, Pandis N. Curing lights for orthodontic bonding: a systematic review and meta-analysis. Am J Orthod Dentofacial } \\
\text { Orthop 2013;143(4 Suppl):S92-103. }\end{array}$ & Included \\
\hline 1026 & $\begin{array}{l}\text { Fleming PS, Johal A, Pandis N. Self-etch primers and conventional acid-etch technique for orthodontic bonding: a systematic review and meta-analysis. } \\
\text { Am J Orthod Dentofacial Orthop 2012;142(1):83-94. }\end{array}$ & Included \\
\hline 1027 & $\begin{array}{l}\text { Flores-Mir C, McGrath L, Heo G, Major P. Efficiency of molar distalization associated with second and third molar eruption stage: a systematic review. } \\
\text { Angle Orthodontist. 2013;83(4):[735-42. }\end{array}$ & Included \\
\hline 1028 & $\begin{array}{l}\text { Foersch M, Jacobs C, Wriedt S, Hechtner M, Wehrbein H. Effectiveness of maxillary protraction using facemask with or without maxillary expansion: a } \\
\text { systematic review and meta-analysis. Clinical oral investigations. 2015;19(6):1181-92. }\end{array}$ & Included \\
\hline 1029 & $\begin{array}{l}\text { Fontana M, Cozzani M, Caprioglio A. Non-compliance maxillary molar distalizing appliances: an overview of the last decade. Prog Orthod 2012; } \\
\text { 13(2):[173-84. }\end{array}$ & Included \\
\hline 1030 & $\begin{array}{l}\text { Freitas A, Marquezan M, Nojima M, Alviano D, Maia L. The influence of orthodontic fixed appliances on the oral microbiota: a systematic review. Database } \\
\text { of Abstracts of Reviews of Effects. 2014; (2):[46-55. }\end{array}$ & Included \\
\hline 1031 & $\begin{array}{l}\text { Ge MK, He WL, Chen J, Wen C, Yin X, Hu ZA, et al. Efficacy of low-level laser therapy for accelerating tooth movement during orthodontic treatment: a } \\
\text { systematic review and meta-analysis. Lasers in medical science. } 2015 ; 30(5): 1609-18 .\end{array}$ & Included \\
\hline 1032 & $\begin{array}{l}\text { Gkantidis N, Mistakidis I, Kouskoura T, Pandis N. Effectiveness of non-conventional methods for accelerated orthodontic tooth movement: a systematic } \\
\text { review and meta-analysis. Journal of dentistry. 2014;42(10):1300-19. }\end{array}$ & Included \\
\hline 1033 & $\begin{array}{l}\text { Golz L, Papageorgiou SN, Jager A. Nickel hypersensitivity and orthodontic treatment: a systematic review and meta-analysis. Contact dermatitis. } \\
\text { 2015;73(1):1-14. }\end{array}$ & Included \\
\hline 1034 & $\begin{array}{l}\text { Gong A, Li J, Wang Z, Li Y, Hu F, Li Q, et al. Cranial base characteristics in anteroposterior malocclusions: A meta-analysis. The Angle orthodontist. } \\
\text { 2016;86(4):668-80. }\end{array}$ & Included \\
\hline 1035 & $\begin{array}{l}\text { Grec RH, Janson G, Branco NC, Moura-Grec PG, Patel MP, Castanha Henriques JF. Intraoral distalizer effects with conventional and skeletal anchorage: } \\
\text { a meta-analysis. Am J Orthod Dentofacial Orthop 2013;143(5):602-15. }\end{array}$ & Included \\
\hline 1036 & $\begin{array}{l}\text { Gritsch K, Laroche N, Morgon L, Al-Hity R, Vico L, Colon P, et al. A systematic review of methods for tissue analysis in animal studies on orthodontic mini- } \\
\text { implants. Orthodontics and Craniofacial Research. } 2012 ; 15(3): 135-47 \text {. }\end{array}$ & Included \\
\hline 1037 & $\begin{array}{l}\text { Haas A, Pannuti C, Andrade A, Escobar E, Almeida E, Costa F, et al. Mouthwashes for the control of supragingival biofilm and gingivitis in orthodontic } \\
\text { patients: evidence-based recommendations for clinicians. Database of Abstracts of Reviews of Effects. 2014; (2):[1-8. }\end{array}$ & Included \\
\hline 1038 & $\begin{array}{l}\text { Hassan AH, Al-Saeed SH, Al-Maghlouth BA, Bahammam MA, Linjawi Al, El-Bialy TH. Corticotomy-assisted orthodontic treatment: A systematic review of } \\
\text { the biological basis and clinical effectiveness. Saudi medical journal. 2015;36(7):794-801. }\end{array}$ & Included \\
\hline 1039 & $\begin{array}{l}\text { He WL, Li CJ, Liu ZP, Sun JF, Hu ZA, Yin X, et al. Efficacy of low-level laser therapy in the management of orthodontic pain: a systematic review and } \\
\text { meta-analysis. Lasers in medical science. 2013;28(6):1581-9. }\end{array}$ & Included \\
\hline 1040 & $\begin{array}{l}\text { Hermont AP, Martins CC, Zina LG, Auad SM, Paiva SM, Pordeus IA. Breastfeeding, bottle feeding practices and malocclusion in the primary dentition: a } \\
\text { systematic review of cohort studies. International journal of environmental research and public health. 2015;12(3):3133-51. }\end{array}$ & Included \\
\hline 1041 & $\begin{array}{l}\text { Hochli D, Hersberger-Zurfluh M, Papageorgiou SN, Eliades T. Interventions for orthodontically induced white spot lesions: a systematic review and meta- } \\
\text { analysis. Eur J Orthod } 2016 \text {. }\end{array}$ & Included \\
\hline 1042 & $\begin{array}{l}\text { Homem M, Vieira-Andrade R, Falci S, Ramos-Jorge M, Marques L. Effectiveness of orofacial myofunctional therapy in orthodontic patients: a systematic } \\
\text { review. Database of Abstracts of Reviews of Effects. 2014; (2):[94-9. }\end{array}$ & Included \\
\hline
\end{tabular}




\begin{tabular}{|c|c|c|}
\hline 1043 & $\begin{array}{l}\text { Hong SB, Kusnoto B, Kim EJ, BeGole EA, Hwang HS, Lim HJ. Prognostic factors associated with the success rates of posterior orthodontic miniscrew } \\
\text { implants: A subgroup meta-analysis. Korean J Orthod 2016;46(2):111-26. }\end{array}$ & Included \\
\hline 1044 & $\begin{array}{l}\text { Hoogeveen E, Jansma J, Ren Y. Surgically facilitated orthodontic treatment: a systematic review. Am J Orthod Dentofacial Orthop 2014; 145(4 } \\
\text { Supplement):[S51-64. }\end{array}$ & Included \\
\hline 1046 & $\begin{array}{l}\text { Huang GJ, Bates SB, Ehlert AA, Whiting DP, Chen SSH, Bollen AM. Stability of deep-bite correction: A systematic review. Journal of the World Federation } \\
\text { of Orthodontists. 2012;1(3):e89-e96. }\end{array}$ & Included \\
\hline 1047 & $\begin{array}{l}\text { Huynh NT, Desplats E, Almeida FR. Orthodontics treatments for managing obstructive sleep apnea syndrome in children: A systematic review and meta- } \\
\text { analysis. Sleep medicine reviews. 2016;25:84-94. }\end{array}$ & Included \\
\hline 1048 & $\begin{array}{l}\text { loannidou-Marathiotou I, Zafeiriadis AA, Papadopoulos MA. Root resorption of endodontically treated teeth following orthodontic treatment: a meta- } \\
\text { analysis. Clinical oral investigations. } 2013 ; 17(7): 1733-44 \text {. }\end{array}$ & Included \\
\hline 1049 & $\begin{array}{l}\text { Ishaq RA, AlHammadi MS, Fayed MM, El-Ezz AA, Mostafa Y. Fixed functional appliances with multibracket appliances have no skeletal effect on the } \\
\text { mandible: A systematic review and meta-analysis. Am J Orthod Dentofacial Orthop 2016;149(5):612-24. }\end{array}$ & Included \\
\hline 1050 & $\begin{array}{l}\text { Ivorra-Carbonell L, Montiel-Company JM, Almerich-Silla JM, Paredes-Gallardo V, Bellot-Arcís C. Impact of functional mandibular advancement appliances } \\
\text { on the temporomandibular joint - A systematic review. Medicina oral, patologia oral y cirugia bucal. 2016;21(5):e565-e72. }\end{array}$ & Included \\
\hline 1051 & $\begin{array}{l}\text { Jacob H, Buschang P, Santos-Pinto A. Class II malocclusion treatment using high-pull headgear with a splint: a systematic review. Database of Abstracts } \\
\text { of Reviews of Effects. 2013; (2):[21.e1-7. }\end{array}$ & Included \\
\hline 1054 & $\begin{array}{l}\text { Janiszewska-Olszowska J, Szatkiewicz T, Tomkowski R, Tandecka K, Grocholewicz K. Effect of orthodontic debonding and adhesive removal on the } \\
\text { enamel - current knowledge and future perspectives - a systematic review. Medical science monitor : international medical journal of experimental and } \\
\text { clinical research. 2014;20:1991-2001. }\end{array}$ & Included \\
\hline 1055 & $\begin{array}{l}\text { Janson G, Aliaga-Del Castillo A, Niederberger A. Changes in apical base sagittal relationship in Class II malocclusion treatment with and without premolar } \\
\text { extractions: A systematic review and meta-analysis. The Angle orthodontist. } 2016 \text {. }\end{array}$ & Included \\
\hline 1056 & $\begin{array}{l}\text { Janson G, Sathler R, Fernandes TM, Branco NC, Freitas MR. Correction of Class II malocclusion with Class II elastics: a systematic review. Am J Orthod } \\
\text { Dentofacial Orthop 2013;143(3):383-92. }\end{array}$ & Included \\
\hline 1057 & $\begin{array}{l}\text { Javed F, Al-Kheraif AA, Romanos EB, Romanos GE. Influence of orthodontic forces on human dental pulp: A systematic review. Archives of Oral Biology. } \\
2015 ; 60(2): 347-56 .\end{array}$ & Included \\
\hline 1058 & $\begin{array}{l}\text { Jayaraman J, Wong HM, King NM, Roberts GJ. The French-Canadian data set of Demirjian for dental age estimation: a systematic review and meta- } \\
\text { analysis. Journal of forensic and legal medicine. } 2013 ; 20(5): 373-81 .\end{array}$ & Included \\
\hline 1060 & $\begin{array}{l}\text { Kaklamanos EG, Kolokitha OE. Relation between soft tissue and skeletal changes after mandibular setback surgery: A systematic review and meta- } \\
\text { analysis. J Craniomaxillofac Surg 2016;44(4):427-35. }\end{array}$ & Included \\
\hline 1061 & $\begin{array}{l}\text { Kalemaj Z, Debernardl CL, Buti J. Efficacy of surgical and non-surgical interventions on accelerating orthodontic tooth movement: a systematic review. } \\
\text { European journal of oral implantology. } 2015 ; 8(1): 9-24 \text {. }\end{array}$ & Included \\
\hline 1062 & $\begin{array}{l}\text { Kapoor P, Kharbanda O, Monga N, Miglani R, Kapila S. Effect of orthodontic forces on cytokine and receptor levels in gingival crevicular fluid: a systematic } \\
\text { review. Prog Orthod 2014; (2):[65 p.]. }\end{array}$ & Included \\
\hline 1063 & $\begin{array}{l}\text { Katyal V, Pamula Y, Martin AJ, Daynes CN, Kennedy JD, Sampson WJ. Craniofacial and upper airway morphology in pediatric sleep-disordered } \\
\text { breathing: Systematic review and meta-analysis. Am J Orthod Dentofacial Orthop 2013;143(1):20-30.e3. }\end{array}$ & Included \\
\hline 1064 & $\begin{array}{l}\text { Khamashta-Ledezma L, Naini FB. Systematic review of changes in maxillary incisor exposure and upper lip position with le Fort i type osteotomies with or } \\
\text { without cinch sutures and/or VY closures. International journal of oral and maxillofacial surgery. 2014;43(1):46-61. }\end{array}$ & Included \\
\hline 1065 & $\begin{array}{l}\text { Kloukos D, Eliades T, Sculean A, Katsaros C. Indication and timing of soft tissue augmentation at maxillary and mandibular incisors in orthodontic } \\
\text { patients. A systematic review. Eur J Orthod } 2014 ; 36(4):[442-9 \text {. }\end{array}$ & Included \\
\hline 1067 & $\begin{array}{l}\text { Knudsen TB, Laulund AS, Ingerslev J, Homoe P, Pinholt EM. Improved apnea-hypopnea index and lowest oxygen saturation after maxillomandibular } \\
\text { advancement with or without counterclockwise rotation in patients with obstructive sleep apnea: a meta-analysis. J Oral Maxillofac Surg. 2015;73(4):719- } \\
26 .\end{array}$ & Included \\
\hline 1068 & $\begin{array}{l}\text { Koretsi V, Chatzigianni A, Sidiropoulou S. Enamel roughness and incidence of caries after interproximal enamel reduction: a systematic review. } \\
\text { Orthodontics \& craniofacial research. } 2014 ; 17(1): 1-13 \text {. }\end{array}$ & Included \\
\hline 1069 & $\begin{array}{l}\text { Koretsi V, Zymperdikas VF, Papageorgiou SN, Papadopoulos MA. Treatment effects of removable functional appliances in patients with Class II } \\
\text { malocclusion: a systematic review and meta-analysis. Eur J Orthod 2015;37(4):418-34. }\end{array}$ & Included \\
\hline 1070 & $\begin{array}{l}\text { Kragt L, Dhamo B, Wolvius EB, Ongkosuwito EM. The impact of malocclusions on oral health-related quality of life in children-a systematic review and } \\
\text { meta-analysis. Clinical oral investigations. } 2016 ; 20(8): 1881-94 \text {. }\end{array}$ & Included \\
\hline 1071 & $\begin{array}{l}\text { Lapenaite E, Lopatiene K. Interproximal enamel reduction as a part of orthodontic treatment. Stomatologija / issued by public institution "Odontologijos } \\
\text { studija" [et al]. 2014;16(1):19-24. }\end{array}$ & Included \\
\hline 1072 & $\begin{array}{l}\text { Lee Y, Liao Y. Hard palate-repair technique and facial growth in patients with cleft lip and palate: a systematic review. British Journal of Oral and } \\
\text { Maxillofacial Surgery. 2013; 51(8):[851-7. }\end{array}$ & Included \\
\hline 1074 & Li FJ, Zhang JY, Zeng XT, Guo Y. Low-level laser therapy for orthodontic pain: a systematic review. Lasers in medical science. 2015;30(6):1789-803. & Included \\
\hline 1075 & $\begin{array}{l}\text { Li W, Xiao L, Hu J. The comparison of CPAP and oral appliances in treatment of patients with OSA: a systematic review and meta-analysis. Respiratory } \\
\text { Care. 2013; 58(7):[1184-95. }\end{array}$ & Included \\
\hline 1076 & $\begin{array}{l}\text { Li X, Deng M, Yuan X. [Stability of the anterior teeth and hard tissue of skeletal class III malocclusion after orthodontic surgery: systematic review]. Hua xi } \\
\text { kou qiang yi xue za zhi = Huaxi kouqiang yixue zazhi = West China journal of stomatology. 2015;33(3):267-71. }\end{array}$ & Included \\
\hline 1078 & $\begin{array}{l}\text { Livas C, Delli K. Does Orthodontic Extraction Treatment Improve the Angular Position of Third Molars? A Systematic Review. J Oral Maxillofac Surg. } \\
2016 .\end{array}$ & Included \\
\hline 1079 & Lombardo L, Setti S, Molinari C, Siciliani G. Intra-arch widths: a meta-analysis. International orthodontics. 2013;11(2):177-92. & Included \\
\hline 1080 & $\begin{array}{l}\text { Long H, Pyakurel U, Wang Y, Liao L, Zhou Y, Lai W. Interventions for accelerating orthodontic tooth movement: a systematic review. Angle Orthodontist. } \\
2013 ; 83(1):[164-71 .\end{array}$ & Included \\
\hline 1081 & $\begin{array}{l}\text { Long H, Zhou Y, Pyakurel U, Liao L, Jian F, Xue J, et al. Comparison of adverse effects between lingual and labial orthodontic treatment. The Angle } \\
\text { orthodontist. 2013;83(6):1066-73. }\end{array}$ & Included \\
\hline 1082 & $\begin{array}{l}\text { Long H, Zhou Y, Xue J, Liao L, Ye N, Jian F, et al. The effectiveness of low-level laser therapy in accelerating orthodontic tooth movement: a meta- } \\
\text { analysis. Lasers in medical science. 2015;30(3):1161-70. }\end{array}$ & Included \\
\hline 1083 & $\begin{array}{l}\text { Machado E, Machado P, Grehs RA, Cunali PA. Orthodontics as a therapeutic option for temporomandibular disorders: A systematic review. Dental Press } \\
\text { J Orthod 2012;17(3):98-102. }\end{array}$ & Included \\
\hline 1084 & $\begin{array}{l}\text { Machado-Junior AJ, Zancanella E, Crespo AN. Rapid maxillary expansion and obstructive sleep apnea: A review and meta-analysis. Medicina oral, } \\
\text { patologia oral y cirugia bucal. 2016;21(4):e465-9. }\end{array}$ & Included \\
\hline 1085 & $\begin{array}{l}\text { Mai W, He J, Meng H, Jiang Y, Huang C, Li M, et al. Comparison of vacuum-formed and Hawley retainers: a systematic review. Database of Abstracts of } \\
\text { Reviews of Effects. 2014; (2):[720-7. }\end{array}$ & Included \\
\hline 1086 & $\begin{array}{l}\text { Major MP, Wong JK, Saltaji H, Major PW, Flores-Mir C. Skeletal anchored maxillary protraction for midface deficiency in children and early adolescents } \\
\text { with Class III malocclusion: A systematic review and meta-analysis. Journal of the World Federation of Orthodontists. 2012;1(2):e47-e54. }\end{array}$ & Included \\
\hline 1087 & $\begin{array}{l}\text { Marquezan M, Mattos CT, Sant'Anna EF, de Souza MM, Maia LC. Does cortical thickness influence the primary stability of miniscrews?: A systematic } \\
\text { review and meta-analysis. The Angle orthodontist. } 2014 ; 84(6): 1093-103 \text {. }\end{array}$ & Included \\
\hline 1089 & $\begin{array}{l}\text { Martin-Camean A, Jos A, Camean AM, Solano E, Iglesias-Linares A. Genotoxic and cytotoxic effects and gene expression changes induced by fixed } \\
\text { orthodontic appliances in oral mucosa cells of patients: a systematic review. Toxicology mechanisms and methods. 2015;25(6):440-7. }\end{array}$ & Included \\
\hline 1090 & Mattos CT. Análise tomográfica das vias aéreas e sua aplicação em pacientes ortognáticos. 2012:94-. & Included \\
\hline 1091 & $\begin{array}{l}\text { Meursinge Reynders R, Ronchi L, Ladu L, Van Etten-Jamaludin F, Bipat S. Insertion torque and orthodontic mini-implants: a systematic review of the } \\
\text { artificial bone literature. Proceedings of the Institution of Mechanical Engineers Part H, Journal of engineering in medicine. 2013;227(11):1181-202. }\end{array}$ & Included \\
\hline 1092 & $\begin{array}{l}\text { Meursinge RR, Ronchi L, Ladu L, Etten-Jamaludin F, Bipat S. Insertion torque and success of orthodontic mini-implants: a systematic review. Am J Orthod } \\
\text { Dentofacial Orthop 2012; 142(5):[596-614.e5. }\end{array}$ & Included \\
\hline 1093 & $\begin{array}{l}\text { Mickenautsch S, Yengopal V, Banerjee A. Retention of orthodontic brackets bonded with resin-modified GIC versus composite resin adhesives--a } \\
\text { quantitative systematic review of clinical trials. Clinical oral investigations. 2012;16(1):1-14. }\end{array}$ & Included \\
\hline 1094 & $\begin{array}{l}\text { Migliorati M, Isaia L, Cassaro A, Rivetti A, Silvestrini-Biavati F, Gastaldo L, et al. Efficacy of professional hygiene and prophylaxis on preventing plaque } \\
\text { increase in orthodontic patients with multibracket appliances: a systematic review. Database of Abstracts of Reviews of Effects. 2014; (2):[epub p.]. }\end{array}$ & Included \\
\hline 1095 & $\begin{array}{l}\text { Millett D, Cunningham S, O'Brien K, Benson P, Oliveira C. Treatment and stability of class II division } 2 \text { malocclusion in children and adolescents: a } \\
\text { systematic review. Am J Orthod Dentofacial Orthop 2012; 142(2):[159-69. }\end{array}$ & Included \\
\hline 1098 & $\begin{array}{l}\text { Morales-Fernandez M, Iglesias-Linares A, Yanez-Vico R, Mendoza-Mendoza A, Solano-Reina E. Bone- and dentoalveolar-anchored dentofacial } \\
\text { orthopedics for class III malocclusion: new approaches, similar objectives? A systematic review. Angle Orthodontist. 2013; 83(3):[540-52 pp.]. }\end{array}$ & Included \\
\hline 1099 & Nascimento L, Souza M, Azevedo A, Maia L. Are self-ligating brackets related to less formation of Streptococcus mutans colonies? A systematic review. & Included \\
\hline
\end{tabular}




\begin{tabular}{|c|c|c|}
\hline & Database of Abstracts of Reviews of Effects. 2014; (2):[60-8. & \\
\hline 1100 & $\begin{array}{l}\text { Nascimento PL, Fernandes MT, Figueiredo FE, Faria ESAL. Fluoride-Releasing Materials to Prevent White Spot Lesions around Orthodontic Brackets: A } \\
\text { Systematic Review. Brazilian dental journal. 2016;27(1):101-7. }\end{array}$ & Included \\
\hline 1101 & $\begin{array}{l}\text { Nazarali N, Altalibi M, Nazarali S, Major MP, Flores-Mir C, Major PW. Mandibular advancement appliances for the treatment of paediatric obstructive sleep } \\
\text { apnea: a systematic review. Eur J Orthod 2015;37(6):618-26. }\end{array}$ & Included \\
\hline 1102 & $\begin{array}{l}\text { Nucera R, Lo Giudice A, Rustico L, Matarese G, Papadopoulos MA, Cordasco G. Effectiveness of orthodontic treatment with functional appliances on } \\
\text { maxillary growth in the short term: A systematic review and meta-analysis. Am J Orthod Dentofacial Orthop 2016;149(5):600-11.e3. }\end{array}$ & Included \\
\hline 1103 & $\begin{array}{l}\text { Okada EM, Ribeiro LN, Stuani MB, Borsatto MC, Fidalgo TK, Paula-Silva FW, et al. Effects of chlorhexidine varnish on caries during orthodontic } \\
\text { treatment: a systematic review and meta-analysis. Brazilian oral research. 2016;30(1):e115. }\end{array}$ & Included \\
\hline 1104 & $\begin{array}{l}\text { Okuno K, Sato K, Arisaka T, Hosohama K, Gotoh M, Taga } \mathrm{H} \text {, et al. The effect of oral appliances that advanced the mandible forward and limited mouth } \\
\text { opening in patients with obstructive sleep apnea: a systematic review and meta-analysis of randomised controlled trials. Journal of oral rehabilitation. } \\
2014 ; 41(7): 542-54 \text {. }\end{array}$ & Included \\
\hline 1105 & $\begin{array}{l}\text { Pacha MM, Fleming PS, Johal A. A comparison of the efficacy of fixed versus removable functional appliances in children with Class II malocclusion: A } \\
\text { systematic review. Eur J Orthod } 2016 ; 38(6): 621-30 \text {. }\end{array}$ & Included \\
\hline 1106 & $\begin{array}{l}\text { Pacheco-Pereira C, Luca CG, Major P, Flores-Mir C. Variation of orthodontic treatment decision-making based on dental model type: a systematic review. } \\
\text { Database of Abstracts of Reviews of Effects. 2014; (2):[epub. }\end{array}$ & Included \\
\hline 1107 & $\begin{array}{l}\text { Pandis N, Fleming PS, Spineli LM, Salanti G. Initial orthodontic alignment effectiveness with self-ligating and conventional appliances: a network meta- } \\
\text { analysis in practice. Am J Orthod Dentofacial Orthop 2014;145(4 Suppl):S152-63. }\end{array}$ & Included \\
\hline 1108 & $\begin{array}{l}\text { Papadopoulos MA, Koumpridou EN, Vakalis ML, Papageorgiou SN. Effectiveness of pre-surgical infant orthopedic treatment for cleft lip and palate } \\
\text { patients: a systematic review and meta-analysis. Orthodontics \& craniofacial research. 2012;15(4):207-36. }\end{array}$ & Included \\
\hline 1109 & $\begin{array}{l}\text { Papageorgiou SN, Golz L, Jager A, Eliades T, Bourauel C. Lingual vs. labial fixed orthodontic appliances: systematic review and meta-analysis of } \\
\text { treatment effects. European journal of oral sciences. 2016;124(2):105-18. }\end{array}$ & Included \\
\hline 1110 & $\begin{array}{l}\text { Papageorgiou SN, Konstantinidis I, Papadopoulou K, Jager A, Bourauel C. A systematic review and meta-analysis of experimental clinical evidence on } \\
\text { initial aligning archwires and archwire sequences. Orthodontics \& craniofacial research. 2014;17(4):197-215. }\end{array}$ & Included \\
\hline 1111 & $\begin{array}{l}\text { Papageorgiou SN, Konstantinidis I, Papadopoulou K, Jager A, Bourauel C. Clinical effects of pre-adjusted edgewise orthodontic brackets: a systematic } \\
\text { review and meta-analysis. Eur J Orthod 2014;36(3):350-63. }\end{array}$ & Included \\
\hline 1112 & $\begin{array}{l}\text { Papageorgiou SN, Kutschera E, Memmert S, Golz L, Jager A, Bourauel C, et al. Effectiveness of early orthopaedic treatment with headgear: a systematic } \\
\text { review and meta-analysis. Eur J Orthod } 2016 \text {. }\end{array}$ & Included \\
\hline 1113 & $\begin{array}{l}\text { Papageorgiou SN, Zogakis IP, Papadopoulos MA. Failure rates and associated risk factors of orthodontic miniscrew implants: a meta-analysis. Am J } \\
\text { Orthod Dentofacial Orthop 2012;142(5):577-95.e7. }\end{array}$ & Included \\
\hline 1114 & $\begin{array}{l}\text { Parrini S, Rossini G, Castroflorio T, Fortini A, Deregibus A, Debernardi C. Laypeople's perceptions of frontal smile esthetics: A systematic review. Am J } \\
\text { Orthod Dentofacial Orthop 2016;150(5):740-50. }\end{array}$ & Included \\
\hline 1115 & $\begin{array}{l}\text { Peiro-Guijarro MA, Guijarro-Martinez R, Hernandez-Alfaro F. Surgery first in orthognathic surgery: A systematic review of the literature. Am J Orthod } \\
\text { Dentofacial Orthop 2016;149(4):448-62. }\end{array}$ & Included \\
\hline 1116 & $\begin{array}{l}\text { Peres KG, Cascaes AM, Nascimento GG, Victora CG. Effect of breastfeeding on malocclusions: a systematic review and meta-analysis. Acta paediatrica } \\
\text { (Oslo, Norway : 1992). 2015;104(467):54-61. }\end{array}$ & Included \\
\hline 1117 & $\begin{array}{l}\text { Perinetti G, Primozic J, Franchi L, Contardo L. Treatment Effects of Removable Functional Appliances in Pre-Pubertal and Pubertal Class II Patients: A } \\
\text { Systematic Review and Meta-Analysis of Controlled Studies. PloS one. 2015;10(10):e0141198. }\end{array}$ & Included \\
\hline 1118 & $\begin{array}{l}\text { Perinetti G, Primozic J, Furlani G, Franchi L, Contardo L. Treatment effects of fixed functional appliances alone or in combination with multibracket } \\
\text { appliances: A systematic review and meta-analysis. The Angle orthodontist. 2015;85(3):480-92. }\end{array}$ & Included \\
\hline 1119 & $\begin{array}{l}\text { Perinetti G, Primozic J, Manfredini D, Lenarda R, Contardo L. The diagnostic potential of static body-sway recording in orthodontics: a systematic review. } \\
\text { Database of Abstracts of Reviews of Effects. 2013; (2):[696-705. }\end{array}$ & Included \\
\hline 1120 & $\begin{array}{l}\text { Perinetti G, Westphalen GH, Biasotto M, Salgarello S, Contardo L. The diagnostic performance of dental maturity for identification of the circumpubertal } \\
\text { growth phases: a meta-analysis. Prog Orthod 2013;14:8. }\end{array}$ & Included \\
\hline 1121 & Petti S. Over two hundred million injuries to anterior teeth attributable to large overjet: a meta-analysis. Dental Traumatology. 2015;31(1):1-8. & Included \\
\hline 1122 & $\begin{array}{l}\text { Pisani L, Bonaccorso L, Fastuca R, Spena R, Lombardo L, Caprioglio A. Systematic review for orthodontic and orthopedic treatments for anterior open } \\
\text { bite in the mixed dentition. Prog Orthod 2016;17(1):28. }\end{array}$ & Included \\
\hline 1123 & $\begin{array}{l}\text { Poorsattar-Bejeh Mir K, Poorsattar-Bejeh Mir A, Poorsattar-Bejeh Mir M, Moradi-Lakeh M, Balmeh P, Nosrati K. Rapid Palatal Expansion to Treat } \\
\text { Nocturnal Enuretic Children: a Systematic Review and Meta-Analysis. Journal of dentistry (Shiraz, Iran). 2015;16(3):138-48. }\end{array}$ & Included \\
\hline 1124 & $\begin{array}{l}\text { Ramar K, Dort LC, Katz SG, Lettieri CJ, Harrod CG, Thomas SM, et al. Clinical Practice Guideline for the Treatment of Obstructive Sleep Apnea and } \\
\text { Snoring with Oral Appliance Therapy: An Update for 2015. Journal of clinical sleep medicine : JCSM : official publication of the American Academy of } \\
\text { Sleep Medicine. 2015;11(7):773-827. }\end{array}$ & Included \\
\hline 1125 & $\begin{array}{l}\text { Raza H, Saltaji H, Kaur H, Flores-Mir C, El-Bialy T. Effect of Low-Intensity Pulsed Ultrasound on Distraction Osteogenesis Treatment Time: A Meta- } \\
\text { analysis of Randomized Clinical Trials. Journal of ultrasound in medicine : official journal of the American Institute of Ultrasound in Medicine. } \\
\text { 2016;35(2):349-58. }\end{array}$ & Included \\
\hline 1126 & $\begin{array}{l}\text { Ren C, McGrath C, Yang Y. The effectiveness of low-level diode laser therapy on orthodontic pain management: a systematic review and meta-analysis. } \\
\text { Lasers in medical science. 2015;30(7):1881-93. }\end{array}$ & Included \\
\hline 1127 & $\begin{array}{l}\text { Rischen RJ, Breuning KH, Bronkhorst EM, Kuijpers-Jagtman AM. Records needed for orthodontic diagnosis and treatment planning: a systematic review. } \\
\text { PloS one. 2013;8(11):e74186. }\end{array}$ & Included \\
\hline 1128 & $\begin{array}{l}\text { Rodriguez JC, Suarez F, Chan HL, Padial-Molina M, Wang HL. Implants for orthodontic anchorage: success rates and reasons of failures. Implant } \\
\text { dentistry. 2014;23(2):155-61. }\end{array}$ & Included \\
\hline 1129 & $\begin{array}{l}\text { Rosario HD, Oliveira GM, Freires IA, de Souza Matos F, Paranhos LR. Efficiency of bimaxillary advancement surgery in increasing the volume of the } \\
\text { upper airways: a systematic review of observational studies and meta-analysis. Eur Arch Otorhinolaryngol } 2016 \text {. }\end{array}$ & Included \\
\hline 1130 & $\begin{array}{l}\text { Roscoe MGG Meira JB, Cattaneo PM. Association of orthodontic force system and root resorption: A systematic review. Am J Orthod Dentofacial Orthop } \\
2015 ; 147(5): 610-26 \text {. }\end{array}$ & Included \\
\hline 1131 & $\begin{array}{l}\text { Rossini G, Parrini S, Castroflorio T, Deregibus A, Debernardi C. Efficacy of clear aligners in controlling orthodontic tooth movement: a systematic review. } \\
\text { Database of Abstracts of Reviews of Effects. 2014; (2):[epub. }\end{array}$ & Included \\
\hline 1132 & $\begin{array}{l}\text { Rossini G, Parrini S, Castroflorio T, Deregibus A, Debernardi C. Periodontal health during clear aligners treatment: a systematic review. Database of } \\
\text { Abstracts of Reviews of Effects. 2014; (2):[epub. }\end{array}$ & Included \\
\hline 1133 & $\begin{array}{l}\text { Saltaji H, Major M, Alfakir H, Al-Saleh M, Flores-Mir C. Maxillary advancement with conventional orthognathic surgery in patients with cleft lip and palate: } \\
\text { is it a stable technique?. Journal of Oral and Maxillofacial Surgery. 2012; 70(12):[2859-66. }\end{array}$ & Included \\
\hline 1134 & $\begin{array}{l}\text { Saltaji H, Major M, Altalibi M, Youssef M, Flores-Mir C. Long-term skeletal stability after maxillary advancement with distraction osteogenesis in cleft lip } \\
\text { and palate patients: a systematic review. Angle Orthodontist. 2012; 82(6):[1115-22. }\end{array}$ & Included \\
\hline 1135 & $\begin{array}{l}\text { Samsonyanová L, Broukal Z. A systematic review of individual motivational factors in orthodontic treatment: Facial attractiveness as the main motivational } \\
\text { factor in orthodontic treatment. International Journal of Dentistry. 2014;2014. }\end{array}$ & Included \\
\hline 1136 & $\begin{array}{l}\text { San Miguel Moragas J, Oth O, Büttner M, Mommaerts MY. A systematic review on soft-to-hard tissue ratios in orthognathic surgery part II: Chin } \\
\text { procedures. Journal of Cranio-Maxillofacial Surgery. 2015;43(8):1530-40. }\end{array}$ & Included \\
\hline 1137 & $\begin{array}{l}\text { San MMJ, Cauteren W, Mommaerts M. A systematic review on soft-to-hard tissue ratios in orthognathic surgery part I: maxillary repositioning osteotomy. } \\
\text { Database of Abstracts of Reviews of Effects. 2014; (2):[1341-51. }\end{array}$ & Included \\
\hline 1138 & $\begin{array}{l}\text { Sandhu SS, Cheema MS, Khehra HS. Comparative effectiveness of pharmacologic and nonpharmacologic interventions for orthodontic pain relief at peak } \\
\text { pain intensity: A Bayesian network meta-analysis. Am J Orthod Dentofacial Orthop 2016;150(1):13-32. }\end{array}$ & Included \\
\hline 1139 & $\begin{array}{l}\text { Shi Q, Yang S, Jia F, Xu J. Does low level laser therapy relieve the pain caused by the placement of the orthodontic separators?--A meta-analysis. Head } \\
\text { \& face medicine. 2015;11:28. }\end{array}$ & Included \\
\hline 1140 & $\begin{array}{l}\text { Sitzman TJ, Coyne SM, Britto MT. The Burden of Care for Children With Unilateral Cleft Lip: A Systematic Review of Revision Surgery. Cleft Palate } \\
\text { Craniofac J 2016;53(4):84-94. }\end{array}$ & Included \\
\hline 1141 & $\begin{array}{l}\text { Sousa MVS, Pinzan A, Consolaro A, Henriques JFC, De Freitas MR. Systematic literature review: Influence of low-level laser on orthodontic movement } \\
\text { and pain control in humans. Photomedicine and Laser Surgery. 2014;32(11):592-9. }\end{array}$ & Included \\
\hline 1142 & $\begin{array}{l}\text { Sundararaj D, Venkatachalapathy S, Tandon A, Pereira A. Critical evaluation of incidence and prevalence of white spot lesions during fixed orthodontic } \\
\text { appliance treatment: A meta-analysis. Journal of International Society of Preventive \& Community Dentistry. 2015;5(6):433-9. }\end{array}$ & Included \\
\hline 1143 & $\begin{array}{l}\text { Sunnak R, Johal A, Fleming PS. Is orthodontics prior to } 11 \text { years of age evidence-based? A systematic review and meta-analysis. Journal of dentistry. } \\
\text { 2015;43(5):477-86. }\end{array}$ & Included \\
\hline 1144 & Tannure PN, Oliveira CA, Maia LC, Vieira AR, Granjeiro JM, Costa Mde C. Prevalence of dental anomalies in nonsyndromic individuals with cleft lip and & Included \\
\hline
\end{tabular}




\begin{tabular}{|c|c|c|}
\hline & palate: a systematic review and meta-analysis. Cleft Palate Craniofac J 2012;49(2):194-200. & \\
\hline 1145 & $\begin{array}{l}\text { Te Veldhuis EC, Te Veldhuis AH, Koudstaal MJ. Treatment management of children with juvenile idiopathic arthritis with temporomandibular joint } \\
\text { involvement: A systematic review. Oral surgery, oral medicine, oral pathology and oral radiology. } 2014 ; 117(5): 581-9 . e 2 .\end{array}$ & Included \\
\hline 1146 & $\begin{array}{l}\text { Tee BC, Sun Z. Mandibular distraction osteogenesis assisted by cell-based tissue engineering: a systematic review. Orthodontics \& craniofacial research. } \\
2015 ; 18 \text { Suppl 1:39-49. }\end{array}$ & Included \\
\hline 1148 & $\begin{array}{l}\text { Tieu L, Saltaji H, Normando D, Flores-Mir C. Radiologically determined orthodontically induced external apical root resorption in incisors after non-surgical } \\
\text { orthodontic treatment of class II division } 1 \text { malocclusion: a systematic review. Database of Abstracts of Reviews of Effects. 2014; (2):[48. }\end{array}$ & Included \\
\hline 1149 & $\begin{array}{l}\text { Tsichlaki A, Chin SY, Pandis N, Fleming PS. How long does treatment with fixed orthodontic appliances last? A systematic review. Am J Orthod } \\
\text { Dentofacial Orthop 2016;149(3):308-18. }\end{array}$ & Included \\
\hline 1150 & $\begin{array}{l}\text { Tsichlaki A, O'Brien K. Do orthodontic research outcomes reflect patient values? A systematic review of randomized controlled trials involving children. } \\
\text { Database of Abstracts of Reviews of Effects. } 2014 ;(2):[279-85 \text {. }\end{array}$ & Included \\
\hline 1151 & $\begin{array}{l}\text { Tsui W, Chua H, Cheung L. Bone anchor systems for orthodontic application: a systematic review. International journal of oral and maxillofacial surgery. } \\
\text { 2012; 41(11):[1427-38. }\end{array}$ & Included \\
\hline 1152 & $\begin{array}{l}\text { Vaid NR, Doshi VM, Vandekar MJ. Class II treatment with functional appliances: A meta-analysis of short-term treatment effects. Seminars in orthodontics. } \\
\text { 2014;20(4):324-38. }\end{array}$ & Included \\
\hline 1153 & $\begin{array}{l}\text { van der Heijden P, Dijkstra PU, Stellingsma C, van der Laan BF, Korsten-Meijer AG, Goorhuis-Brouwer SM. Limited evidence for the effect of presurgical } \\
\text { nasoalveolar molding in unilateral cleft on nasal symmetry: a call for unified research. Plastic and reconstructive surgery. 2013;131(1):62e-71e. }\end{array}$ & Included \\
\hline 1154 & $\begin{array}{l}\text { Verweij JP, Houppermans PN, Gooris P, Mensink G, van Merkesteyn JP. Risk factors for common complications associated with bilateral sagittal split } \\
\text { osteotomy: A literature review and meta-analysis. J Craniomaxillofac Surg 2016;44(9):1170-80. }\end{array}$ & Included \\
\hline 1155 & $\begin{array}{l}\text { Vilani GN, Mattos CT, de Oliveira Ruellas AC, Maia LC. Long-term dental and skeletal changes in patients submitted to surgically assisted rapid maxillary } \\
\text { expansion: a meta-analysis. Oral surgery, oral medicine, oral pathology and oral radiology. 2012;114(6):689-97. }\end{array}$ & Included \\
\hline 1156 & $\begin{array}{l}\text { Viwattanatipa N, Puntien T, Nanthavanich N. Systematic review and meta-analysis: Mandibular plane change after orthognathic surgery and distraction } \\
\text { osteogenesis in cleft lip and palate patients. Orthodontic Waves. 2015;74(2):27-36. }\end{array}$ & Included \\
\hline 1157 & $\begin{array}{l}\text { Viwattanatipa N, Puntien T, Thakkinstian A. Systematic review and meta-analysis of maxillary change among } 3 \text { surgical techniques in cleft patients. } \\
\text { Orthodontic Waves. 2013;72(2):63-76. }\end{array}$ & Included \\
\hline 1158 & $\begin{array}{l}\text { von Bremen J, Ruf S. Juvenile idiopathic arthritis-and now?: a systematic literature review of changes in craniofacial morphology. J Orofac Orthop } \\
\text { 2012;73(4):265-76. }\end{array}$ & Included \\
\hline 1160 & $\begin{array}{l}\text { Yamaguchi K, Lonic D, Lo LJ. Complications following orthognathic surgery for patients with cleft lip/palate: A systematic review. Journal of the Formosan } \\
\text { Medical Association. 2016;115(4):269-77. }\end{array}$ & Included \\
\hline 1161 & $\begin{array}{l}\text { Yang X, Li C, Bai D, Su N, Chen T, Xu Y, et al. Treatment effectiveness of Frankel function regulator on the Class III malocclusion: a systematic review } \\
\text { and meta-analysis. Am J Orthod Dentofacial Orthop } 2014 ; 146(2): 143-54 \text {. }\end{array}$ & Included \\
\hline 1162 & $\begin{array}{l}\text { Yang X, Su N, Shi Z, Xiang Z, He Y, Han X, et al. Effects of self-ligating brackets on oral hygiene and discomfort: a systematic review and meta-analysis } \\
\text { of randomized controlled clinical trials. International journal of dental hygiene. } 2016 \text {. }\end{array}$ & Included \\
\hline 1163 & $\begin{array}{l}\text { Yang X, Zhu Y, Long H, Zhou Y, Jian F, Ye N, et al. The effectiveness of the Herbst appliance for patients with Class II malocclusion: a meta-analysis. Eur } \\
\text { J Orthod 2016;38(3):324-33. }\end{array}$ & Included \\
\hline 1164 & $\begin{array}{l}\text { Yepes E, Quintero P, Rueda ZV, Pedroza A. Optimal force for maxillary protraction facemask therapy in the early treatment of class III malocclusion. Eur J } \\
\text { Orthod } 2014 ; 36(5): 586-94 .\end{array}$ & Included \\
\hline 1165 & $\begin{array}{l}\text { Yi J, Ge M, Li M, Li C, Li Y, Li X, et al. Comparison of the success rate between self-drilling and self-tapping miniscrews: a systematic review and meta- } \\
\text { analysis. Eur J Orthod } 2016 \text {. }\end{array}$ & Included \\
\hline 1166 & $\begin{array}{l}\text { Yi J, Li M, Li Y, Li X, Zhao Z. Root resorption during orthodontic treatment with self-ligating or conventional brackets: a systematic review and meta- } \\
\text { analysis. BMC oral health. } 2016 ; 16(1): 125 \text {. }\end{array}$ & Included \\
\hline 1168 & $\begin{array}{l}\text { Zawawi KH, Melis M. The role of mandibular third molars on lower anterior teeth crowding and relapse after orthodontic treatment: A systematic review. } \\
\text { Scientific World Journal. } 2014 ; 2014 \text {. }\end{array}$ & Included \\
\hline 1169 & $\begin{array}{l}\text { Zhang W, Qu HC, Yu M, Zhang Y. The Effects of Maxillary Protraction with or without Rapid Maxillary Expansion and Age Factors in Treating Class III } \\
\text { Malocclusion: A Meta-Analysis. PloS one. 2015;10(6):e0130096. }\end{array}$ & Included \\
\hline 1170 & $\begin{array}{l}\text { Zhou Q, UI Haq AA, Tian L, Chen X, Huang K, Zhou Y. Canine retraction and anchorage loss self-ligating versus conventional brackets: a systematic } \\
\text { review and meta-analysis. BMC oral health. 2015;15(1):136. }\end{array}$ & Included \\
\hline 1171 & $\begin{array}{l}\text { Zhou Y, Long H, Ye N, Xue J, Yang X, Liao L, et al. The effectiveness of non-surgical maxillary expansion: a meta-analysis. Eur J Orthod 2014;36(2):233- } \\
\text { 42. }\end{array}$ & Included \\
\hline 1172 & Zhou Y, Wang Y, Wang X, Voliere G, Hu R. The impact of orthodontic treatment on the quality of life a systematic review. BMC oral health. 2014;14:66. & Included \\
\hline 1173 & $\begin{array}{l}\text { Zhu Y, Li J, Tang Y, Wang X, Xue X, Sun H, et al. Dental arch dimensional changes after adenoidectomy or tonsillectomy in children with airway } \\
\text { obstruction: A meta-analysis and systematic review under PRISMA guidelines. Medicine. 2016;95(39):e4976. }\end{array}$ & Included \\
\hline 1174 & $\begin{array}{l}\text { Zhu Y, Long H, Jian F, Lin J, Zhu J, Gao M, et al. The effectiveness of oral appliances for obstructive sleep apnea syndrome: A meta-analysis. Journal of } \\
\text { dentistry. 2015;43(12):1394-402. }\end{array}$ & Included \\
\hline 1175 & $\begin{array}{l}\text { Zurfluh M, Kloukos D, Patcas R, Eliades T. Effect of chin-cup treatment on the temporomandibular joint: a systematic review. Database of Abstracts of } \\
\text { Reviews of Effects. 2014; (2):[epub. }\end{array}$ & Included \\
\hline 1176 & $\begin{array}{l}\text { Zymperdikas VF, Koretsi V, Papageorgiou SN, Papadopoulos MA. Treatment effects of fixed functional appliances in patients with Class II malocclusion: a } \\
\text { systematic review and meta-analysis. Eur J Orthod 2016;38(2):113-26. }\end{array}$ & Included \\
\hline
\end{tabular}

* protocols of systematic reviews have been classified as "not a systematic review". 
Appendix E. Univariable regression models with \%AMSTAR as dependent variable to choose covariables for the multivariable model of Table 3.

\begin{tabular}{|l|l|l|}
\hline Covariate & $\mathbf{P}$ & $\begin{array}{l}\text { Entered in } \\
\text { multivariable model }\end{array}$ \\
\hline Publication year & 0.02 & Yes \\
\hline Continent & & \\
\hline & 0.99 & No \\
\hline Affiliation & & \\
\hline Number of authors (categorized) & 0.42 & No \\
\hline & 0.09 & Yes \\
\hline Inclusion of statistician & & \\
\hline & 0.02 & Yes \\
\hline Multicenter & & \\
\hline & 0.03 & Yes \\
\hline Funding & & \\
\hline & 0.70 & No \\
\hline Journal category & & \\
\hline & 0.03 & Yes \\
\hline Design of included studies & & \\
\hline & 0.78 & No \\
\hline Number of included studies (categorized) & 0.04 & Yes \\
\hline & & \\
\hline Adherence to PRISMA & $<0.001$ & Yes \\
\hline & & \\
\hline Use of GRADE & $<0.001$ & Yes \\
\hline & & \\
\hline Inclusion of flowdiagram & $<0.001$ & Yes \\
\hline & & \\
\hline Conduct of meta-analysis & $<0.001$ & Yes \\
\hline Statistical significance of results & 0.002 & Yes \\
\hline
\end{tabular}


Appendix F. Univariable logistic regression with partial/complete fulfillment of each AMSTAR item as dependent variable and registration in PROSPERO as independent variable.

\begin{tabular}{|c|c|c|c|}
\hline Factor & Category & OR (95\% Cl) & $\mathbf{P}$ \\
\hline \multirow[t]{2}{*}{ Item 1} & Not registered & Referent & \\
\hline & Registered & $91.32(12.12,688.10)$ & $<0.001$ \\
\hline \multirow[t]{2}{*}{ Item 2} & Not registered & Referent & \\
\hline & Registered & $2.32(0.51,10.54)$ & 0.27 \\
\hline \multirow{2}{*}{ Item 3} & Not registered & Referent & \\
\hline & Registered & $\mathrm{NC}^{*}$ & \\
\hline \multirow[t]{2}{*}{ Item 4} & Not registered & Referent & \\
\hline & Registered & $1.96(0.86,4.45)$ & 0.11 \\
\hline \multirow[t]{2}{*}{ Item 5} & Not registered & Referent & \\
\hline & Registered & $\mathrm{NC}^{*}$ & \\
\hline \multirow[t]{2}{*}{ Item 6} & Not registered & Referent & \\
\hline & Registered & $\mathrm{NC}^{*}$ & \\
\hline \multirow[t]{2}{*}{ Item 7} & Not registered & Referent & \\
\hline & Registered & $\mathrm{NC}^{*}$ & \\
\hline \multirow[t]{2}{*}{ Item 8} & Not registered & Referent & \\
\hline & Registered & $\mathrm{NC}^{*}$ & \\
\hline \multirow[t]{2}{*}{ Item 9} & Not registered & Referent & \\
\hline & Registered & $1.72(0.56,5.29)$ & 0.35 \\
\hline \multirow{2}{*}{ Item 10} & Not registered & Referent & \\
\hline & Registered & $2.62(1.23,5.55)$ & 0.01 \\
\hline \multirow[t]{2}{*}{ Item 11} & Not registered & Referent & \\
\hline & Registered & $0.94(0.44,2.01)$ & 0.88 \\
\hline
\end{tabular}

$\mathrm{Cl}$, confidence interval; $\mathrm{NC}^{*}$, not calculable, as registration perfectly predicts item fulfillment; OR, odds ratio. 
Appendix G. Selection of confounders to be entered in the multivariable model. Separate univariable logistic regressions with partial/complete fulfillment of each AMSTAR item as dependent variable and each independent variable are run and variables with $\mathrm{P}<0.20$ are entered in the multivariable model.

\begin{tabular}{|l|l|l|l|l|l|l|}
\hline & \multicolumn{6}{|c|}{ P value from univariable model to item fulfillment } \\
\hline Variable & Item 1 & Item 2 & Item 4 & Item 9 & Item 10 & Item 11 \\
\hline Publication year & 0.01 & 0.38 & 0.17 & 0.03 & 0.003 & 0.31 \\
\hline & & & & & & \\
\hline Continent & 0.02 & 0.12 & 0.98 & 0.07 & 0.23 & 0.13 \\
\hline & & & & & & \\
\hline Affiliation & 0.96 & 0.81 & 0.86 & NC & 0.36 & 0.21 \\
\hline Number of authors (categorized) & & & & & & \\
\hline & 0.21 & 0.23 & 0.30 & 0.30 & 0.21 & 0.10 \\
\hline Inclusion of statistician & & & & & & \\
\hline & 0.09 & 0.84 & 0.07 & 0.23 & 0.04 & 0.70 \\
\hline Multicenter & & & & & & \\
\hline & 0.11 & 0.22 & 0.74 & 0.66 & 0.91 & 0.17 \\
\hline Funding & & & & & & \\
\hline & 0.06 & 0.32 & 0.90 & 0.48 & 0.28 & 0.03 \\
\hline Journal category & & & & & & \\
\hline & 0.08 & 0.83 & 0.02 & 0.05 & 0.38 & 0.004 \\
\hline Design of included studies & & & & & & \\
\hline & 0.77 & 0.74 & 0.33 & 0.41 & 1.00 & 0.73 \\
\hline Number of included studies (categorized) & 0.64 & 0.03 & 0.09 & 0.15 & 0.98 & 0.33 \\
\hline & & & & & & \\
\hline Adherence to PRISMA & $<0.001$ & 0.03 & 0.02 & 0.17 & 0.05 & 0.77 \\
\hline Use of GRADE & & & & & & \\
\hline & $<0.001$ & 0.19 & 0.001 & 0.04 & $<0.001$ & 0.45 \\
\hline Inclusion of flowdiagram & & & & & & \\
\hline & 0.02 & 0.001 & 0.007 & 0.31 & 0.47 & 0.76 \\
\hline Conduct of meta-analysis & & & & & & \\
\hline Statistical significance of results & 0.001 & 0.50 & 0.01 & $<0.001$ & $<0.001$ & 0.32 \\
\hline
\end{tabular}

GRADE, Grading of Recommendations Assessment, Development and Evaluation; NC, not calculable;

PRISMA, Preferred Reporting Items for Systematic Review and Meta-Analysis. 
Appendix $\mathrm{H}$. Multivariable logistic regression with partial/complete fulfillment of each AMSTAR item as dependent variable and registration in PROSPERO \& confounders from Appendix $G$ as independent variables.

\begin{tabular}{|c|c|c|c|c|c|c|c|c|c|c|c|c|}
\hline & \multicolumn{2}{|c|}{ Item 1} & \multicolumn{2}{|c|}{ Item 2} & \multicolumn{2}{|c|}{ Item 4} & \multicolumn{2}{|c|}{ Item 9} & \multicolumn{2}{|c|}{ Item 10} & \multicolumn{2}{|c|}{ Item 11} \\
\hline & $\begin{array}{l}\text { OR } \\
(95 \% \mathrm{Cl})\end{array}$ & $\mathbf{P}$ & $\begin{array}{l}\text { OR } \\
(95 \% \mathrm{Cl})\end{array}$ & $\mathbf{P}$ & $\begin{array}{l}\text { OR } \\
(95 \% \mathrm{Cl})\end{array}$ & $\mathbf{P}$ & $\begin{array}{l}\text { OR } \\
(95 \% \mathrm{Cl})\end{array}$ & $\mathbf{P}$ & $\begin{array}{l}\text { OR } \\
(95 \% \mathrm{Cl})\end{array}$ & $\mathbf{P}$ & $\begin{array}{l}\text { OR } \\
(95 \% \mathrm{Cl})\end{array}$ & $\mathbf{P}$ \\
\hline \multicolumn{13}{|l|}{ Entered factor } \\
\hline Not registered & Ref & & & & & & & & & & & \\
\hline Registered & $\begin{array}{l}64.92 \\
(8.00,527.03) \\
\end{array}$ & $<0.001$ & $\begin{array}{l}1.04 \\
(0.20,5.46)\end{array}$ & 0.97 & $\begin{array}{l}0.80 \\
(0.30,2.12)\end{array}$ & 0.66 & $\begin{array}{l}0.45 \\
(0.10,1.97) \\
\end{array}$ & 0.29 & $\begin{array}{l}1.23 \\
(0.50,3.00) \\
\end{array}$ & 0.65 & $\begin{array}{l}1.11 \\
(0.49,2.50) \\
\end{array}$ & 0.80 \\
\hline \multicolumn{13}{|l|}{ Confounders } \\
\hline Publication year & $\begin{array}{l}1.13 \\
(0.82,1.57)\end{array}$ & 0.46 & NT & - & $\begin{array}{l}1.05 \\
(0.80,1.38)\end{array}$ & 0.70 & $\begin{array}{l}1.18 \\
(0.80,1.74)\end{array}$ & 0.39 & $\begin{array}{l}1.13 \\
(0.86,1.49)\end{array}$ & 0.38 & NT & - \\
\hline Continent & $\begin{array}{l}0.91 \\
(0.64,1.31)\end{array}$ & 0.62 & $\begin{array}{l}1.60 \\
(1.02,2.49)\end{array}$ & 0.04 & NT & - & $\begin{array}{l}1.31 \\
(0.85,2.02)\end{array}$ & 0.22 & NT & - & $\begin{array}{l}1.08 \\
(0.84,1.40)\end{array}$ & 0.54 \\
\hline $\begin{array}{l}\text { Number of authors } \\
\text { (categorized) }\end{array}$ & NT & - & NT & & NT & - & NT & - & NT & - & $\begin{array}{l}1.24 \\
(0.72,2.12)\end{array}$ & 0.44 \\
\hline Inclusion of statistician & $\begin{array}{l}1.86 \\
(0.59,5.86)\end{array}$ & 0.29 & NT & - & $\begin{array}{l}2.04 \\
(0.68,6.15)\end{array}$ & 0.21 & NT & - & $\begin{array}{l}2.92 \\
(1.03,8.22)\end{array}$ & 0.04 & NT & - \\
\hline Multicenter & $\begin{array}{l}1.15 \\
(0.48,2.72) \\
\end{array}$ & 0.76 & NT & - & NT & - & NT & - & NT & - & $\begin{array}{l}1.80 \\
(0.92,3.53) \\
\end{array}$ & 0.09 \\
\hline Funding & $\begin{array}{l}0.37 \\
(0.12,1.14)\end{array}$ & 0.08 & NT & - & NT & - & NT & - & NT & - & $\begin{array}{l}2.14 \\
(0.86,5.32)\end{array}$ & 0.10 \\
\hline Journal category & $\begin{array}{l}0.61 \\
(0.33,1.14)\end{array}$ & 0.12 & NT & - & $\begin{array}{l}0.59 \\
(0.37,0.94) \\
\end{array}$ & 0.03 & $\begin{array}{l}0.52 \\
(0.26,1.05)\end{array}$ & 0.07 & NT & - & $\begin{array}{l}2.05 \\
(1.24,3.37)\end{array}$ & 0.005 \\
\hline $\begin{array}{l}\text { Number of included } \\
\text { studies (categorized) }\end{array}$ & NT & - & $\begin{array}{l}0.99 \\
(0.97,1.00) \\
\end{array}$ & 0.06 & $\begin{array}{l}0.99 \\
(0.98,1.01)\end{array}$ & 0.22 & $\begin{array}{l}1.00 \\
(0.98,1.01)\end{array}$ & 0.55 & NT & - & NT & - \\
\hline Adherence to PRISMA & $\begin{array}{l}1.66 \\
(0.66,4.19) \\
\end{array}$ & 0.29 & $\begin{array}{l}2.64 \\
(0.80,8.68) \\
\end{array}$ & 0.11 & $\begin{array}{l}1.63 \\
(0.79,3.40) \\
\end{array}$ & 0.19 & $\begin{array}{l}1.89 \\
(0.68,5.21) \\
\end{array}$ & 0.22 & $\begin{array}{l}1.67 \\
(0.79,3.54) \\
\end{array}$ & 0.18 & NT & - \\
\hline Use of GRADE & $\begin{array}{l}4.08 \\
(1.49,11.16)\end{array}$ & 0.006 & $\begin{array}{l}4.84 \\
(0.63,37.04)\end{array}$ & 0.13 & $\begin{array}{l}5.50 \\
(1.80,16.84)\end{array}$ & 0.003 & $\begin{array}{l}6.43 \\
(1.17,35.34)\end{array}$ & 0.03 & $\begin{array}{l}4.20 \\
(1.69,10.41)\end{array}$ & 0.002 & NT & - \\
\hline Inclusion of flowdiagram & $\begin{array}{l}2.28 \\
(0.38,13.60)\end{array}$ & 0.37 & $\begin{array}{l}4.22 \\
(0.14,3.21)\end{array}$ & 0.04 & $\begin{array}{l}2.90 \\
(0.81,10.32)\end{array}$ & 0.10 & NT & - & NT & - & NT & - \\
\hline $\begin{array}{l}\text { Conduct of meta- } \\
\text { analysis }\end{array}$ & $\begin{array}{l}4.37 \\
(1.54,12.36) \\
\end{array}$ & 0.005 & NT & - & $\begin{array}{l}2.11 \\
(1.03,4.32) \\
\end{array}$ & 0.04 & $\begin{array}{l}7.21 \\
(2.21,23.57) \\
\end{array}$ & 0.001 & $\begin{array}{l}7.10 \\
(3.03,16.64) \\
\end{array}$ & $<0.001$ & NT & - \\
\hline $\begin{array}{l}\text { Statistical significance of } \\
\text { results }\end{array}$ & $\begin{array}{l}0.92 \\
(0.35,2.44)\end{array}$ & 0.87 & NT & - & NT & - & $\begin{array}{l}1.40 \\
(0.52,3.76)\end{array}$ & 0.51 & $\begin{array}{l}1.20 \\
(0.52,2.77)\end{array}$ & 0.67 & NT & - \\
\hline
\end{tabular}

$\mathrm{Cl}$, confidence interval; GRADE, Grading of Recommendations Assessment, Development and Evaluation; NT, not tested; OR, odds ratio; PRISMA, Preferred Reporting Items for Systematic Review and Meta-Analysis; PROPSERO, international prospective register of systematic reviews. 


\section{Registration in PROSPERO of systematic review protocols was associated with increased review quality}

\section{What is new?}

\section{Key findings}

- Registration of systematic review protocols is associated with slightly increased review quality

- Registered systematic reviews were more likely to possess favorable methodological characteristics

\section{What this study adds to what was known?}

- Registration of systematic review protocols has been suggested up to now as a means of avoiding duplication, enhancing the transparency of review procedures, and minimizing selective reporting.

- However, registration of the review protocol might be additionally associated with higher review quality and favorable methodological characteristics of the review.

\section{What is the implication and what should change now?}

- Systematic review authors are advised to register the review protocols in PROSPERO a priori. 